\title{
Economics of Large-Scale
} Thorium Oxide Production: Assessment of Domestic Resources
J. K. Young
M. Y. Ballinger
C. H. Bloomster
M. K. Drost
W. I. Enderlin
S. A. Weakley
M. H. Morgenstern

February 1980

Prepared for the U.S. Department of Energy under Contract EY-76-C-06-1830

Pacific Northwest Laboratory Operated for the U.S. Department of Energy by Battelle Memorial Institute 


\title{
NOTICE
}

This report was prepared as an account of work sponsored by the United States Government. Neither the United States nor the Department of Energy, nor any of their employees, nor any of their contractors, subcontractors, or their employees, makes any warranty, express or implied, or assumes any legal liability or responsibility for the accuracy, completeness or usefulness of any information, apparatus, product or process disclosed, or represents that its use would not iniringe privately owned rights.

The views, opinions and conclusions contained in this report are those of the contractor and do not necessarily represent those of the United States Government or the United States Department of Energy.

\author{
PACIFIC NORTHWEST LABORATORY \\ operated by \\ BATTELLF \\ for the \\ UNITED STATES DEPARTMENT OF ENERGY \\ Under Contract EY-76-C-06-7830
}

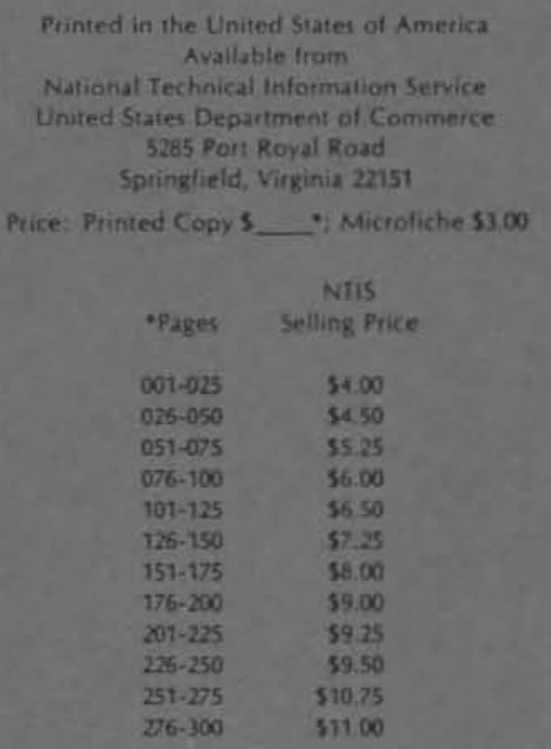


PNL-3150

UC -51

33679000536237

ECONOMICS OF LARGE-SCALE

THORIUM OXIDE PRODUCTION:

ASSESSMENT OF DOMESTIC

RESOURCES

JK Young

$\mathrm{CH}$ Bloomster

WI Enderlin

MH Morgenstern

MY Ballinger

MK Drost

SA Weakley

Februàry 1980

Prepared for

the U.S. Department of Energy

under Contract EY-76-C-06-1830

Pacific Northwest Laboratory

Richland, Washington 99352 


\section{CONTENTS}

1.0 SUMMARY

1.1

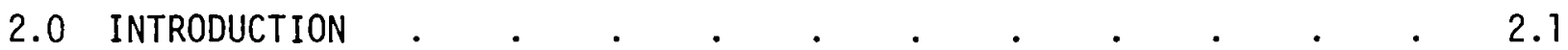

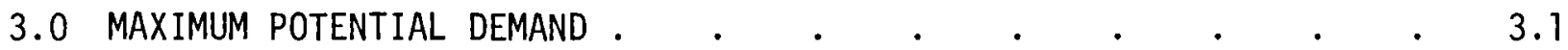

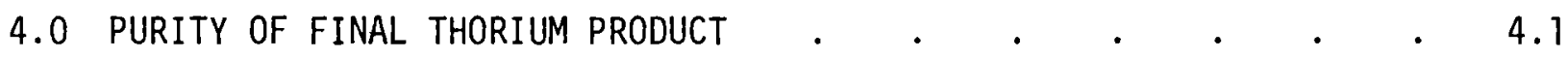

4.1 DEFINITION OF REACTOR-GRADE THORIUM OXIDE $\quad . \quad \ldots \quad . \quad$. 4.1

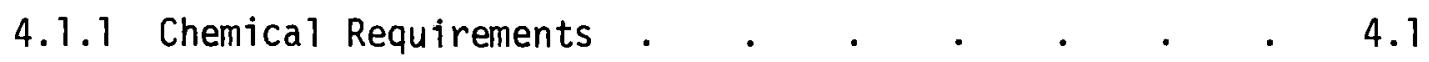

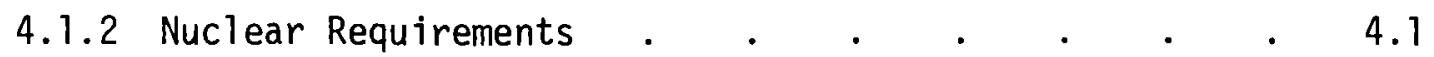

4.1.3 Physical Requirements . . . . . . . . . . 4.4

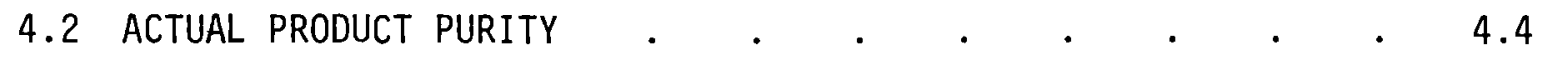

5.0 THORIUM ORES AND THEIR PROCESSING TECHNOLOGY . . . . . . . $\quad 5.1$

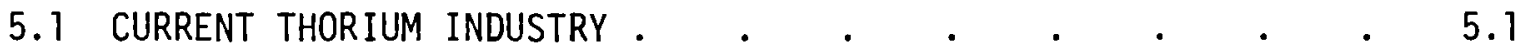

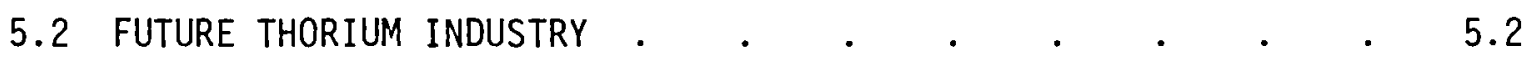

5.2.1 Stockpile Processing Stream . . . . . . $\quad$. 5.2

5.2.2 Thorite Processing Stream . . . . . 5.2

5.2.3 Monazite Conglomerate Processing Stream _ . $\quad$. 5.3

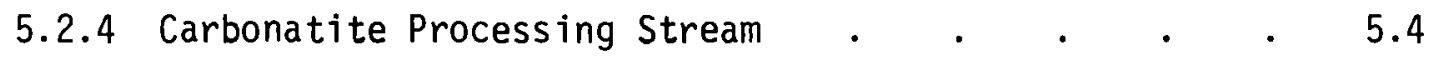

5.2.5 Monazite Sand Processing . $\quad . \quad$. $\quad . \quad$. 5.4

5.2.6 Disseminated Deposit Processing Stream $\quad$. $\quad$. $\quad$. 5.5

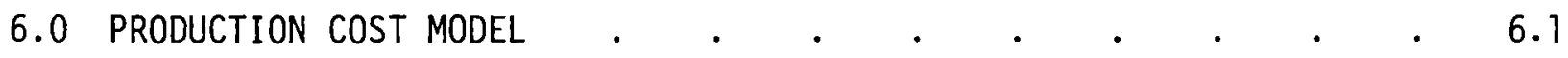

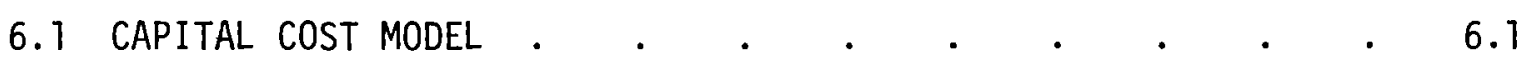

6.1 .1 Buildings and Equipment Cost $\quad . \quad$. $\quad . \quad . \quad$. 6.1

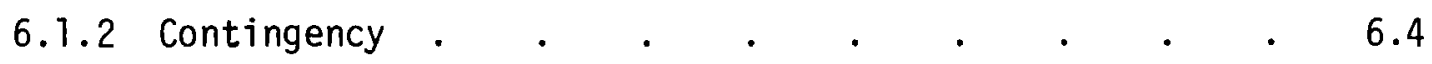

6.7 .3 Tailings Pond . . . . . . . . . . . 6.5

6.1.4 Environmental Impact Assessment . . . . . . $\quad 6.5$ 


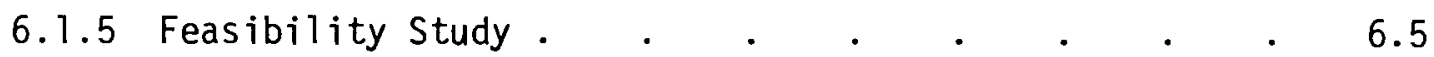

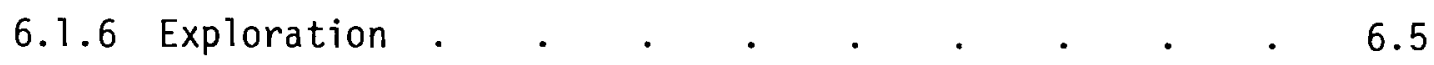

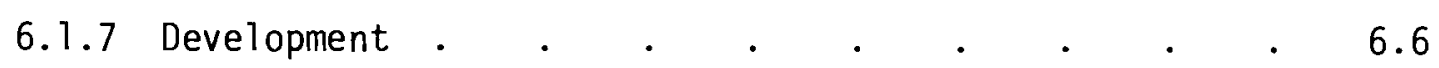

6.1 .8 Access Road . . . . . . . . . . . . . . . 6.6

6.1 .9 Total Land Cost . . . . . . . . . . . . . 6.6

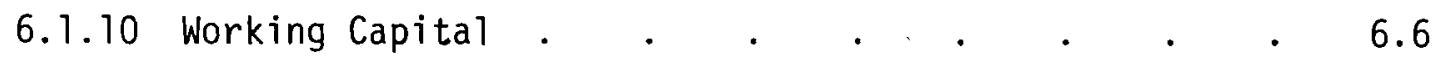

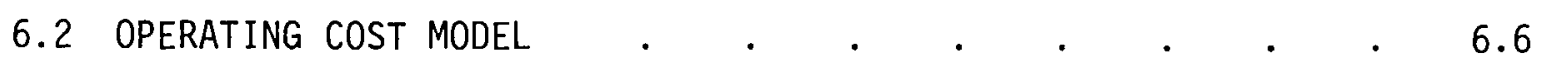

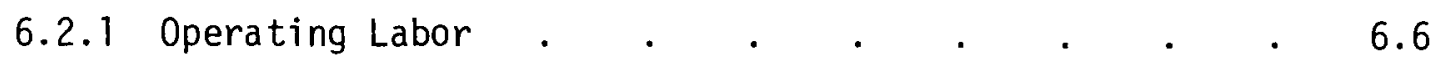

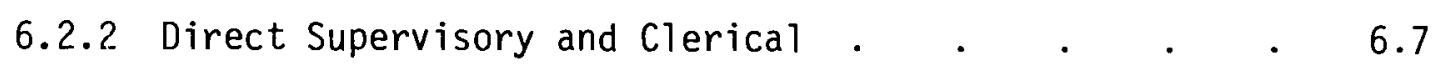

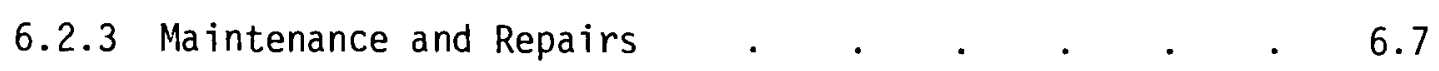

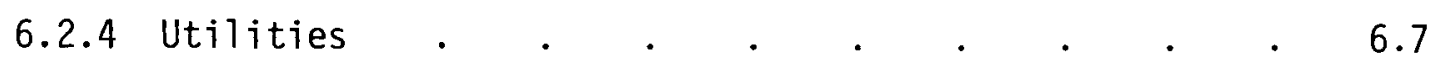

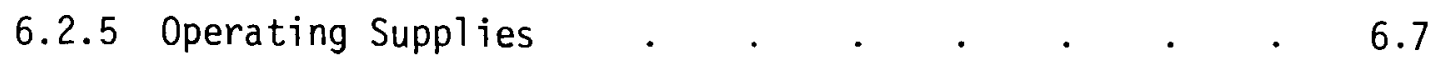

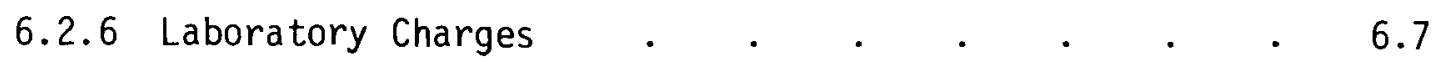

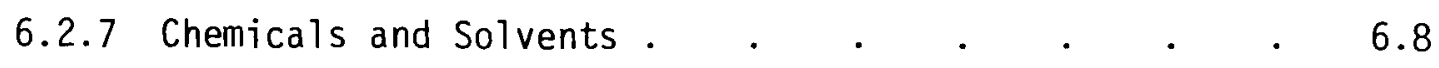

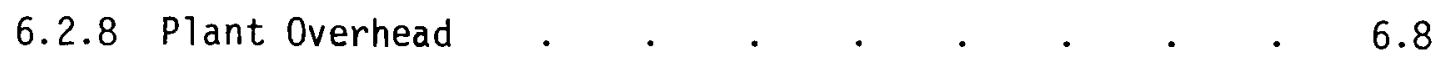

6.2.9 Administrative Overhead . $\quad . \quad$. $\quad . \quad . \quad . \quad 6.8$

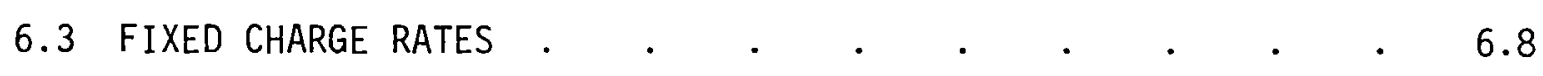

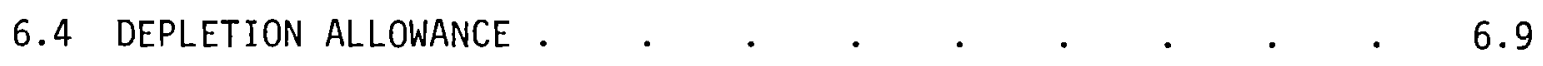

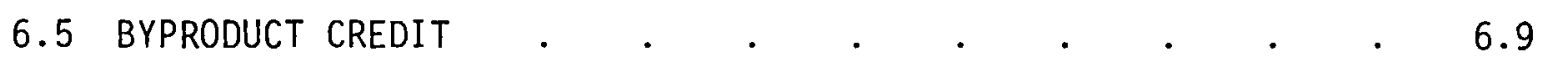

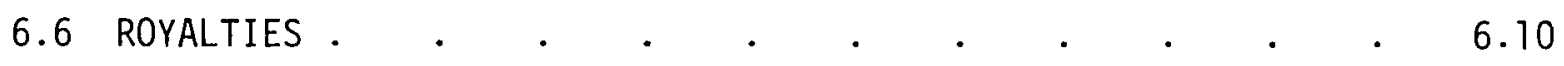

6.7 TRANSPORTATION .

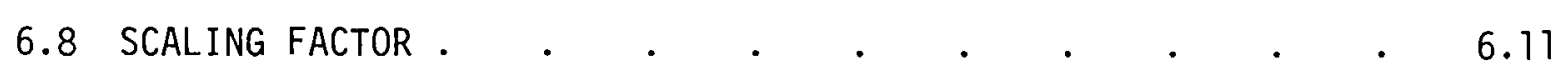

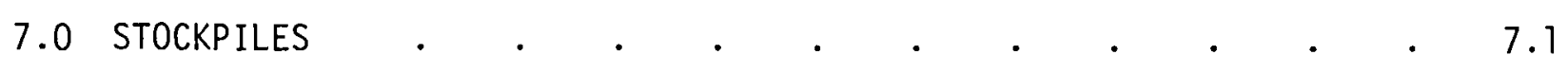

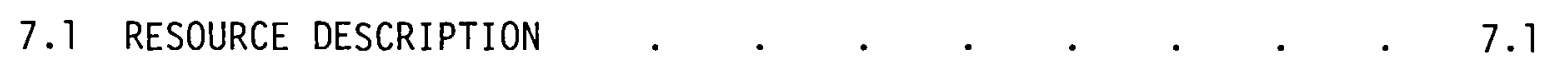

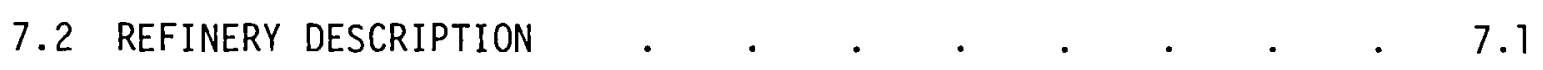




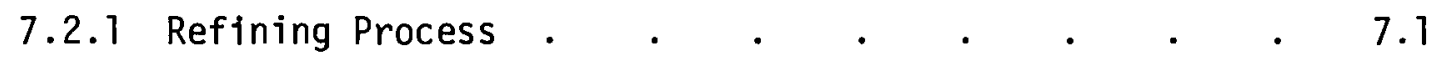

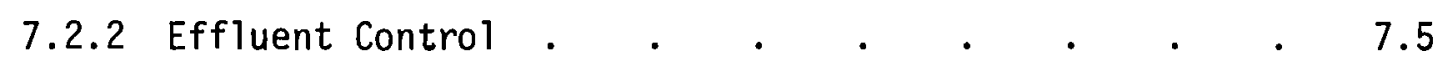

7.3 STOCKPILED THORIUM PRODUCTION COST .

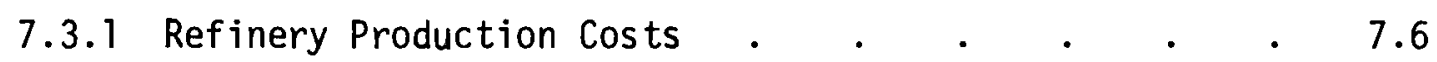

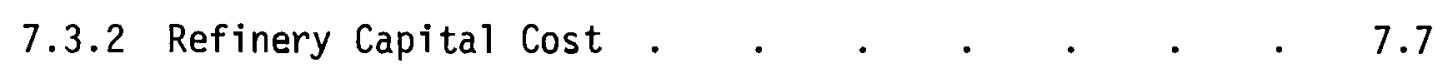

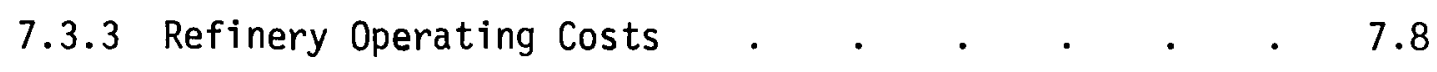

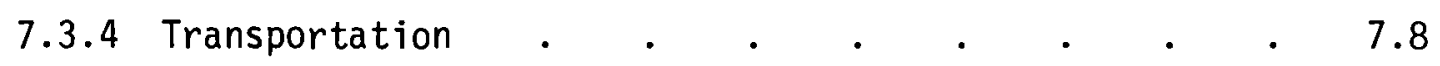

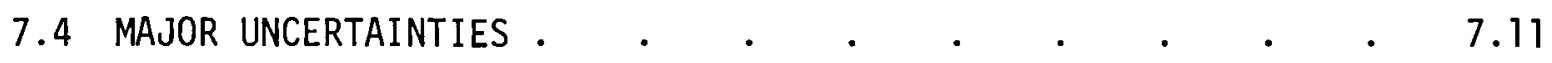

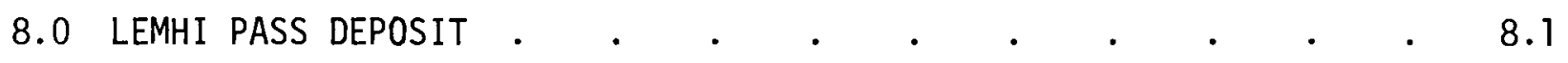

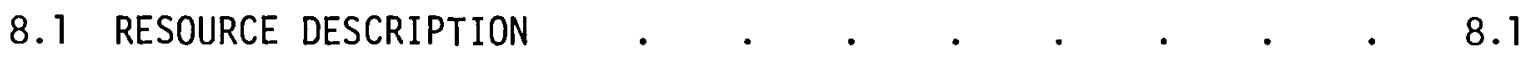

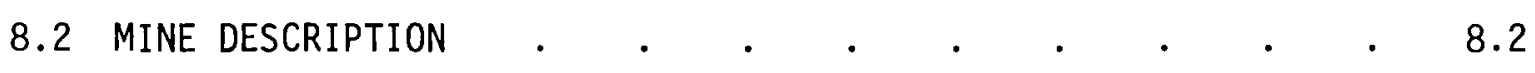

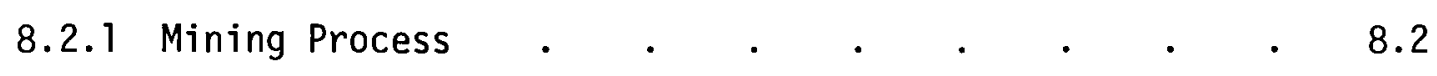

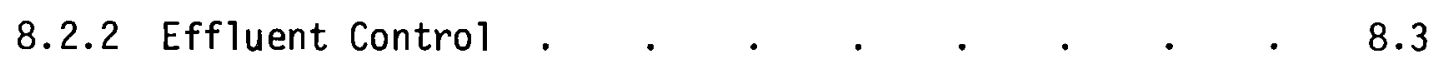

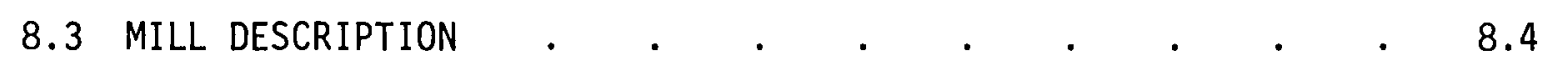

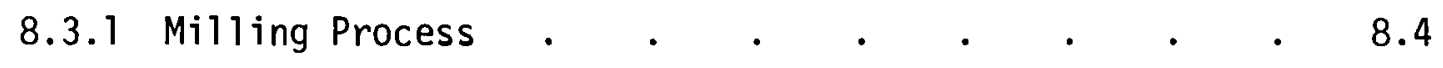

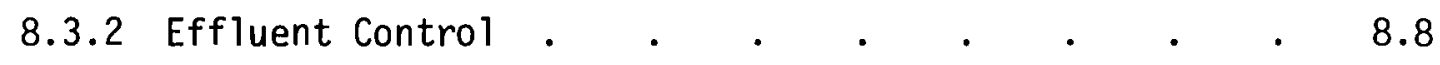

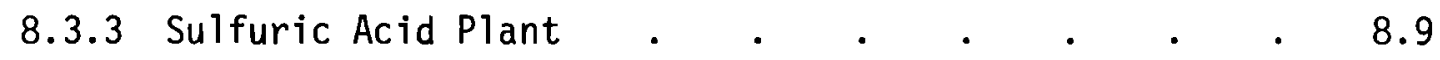

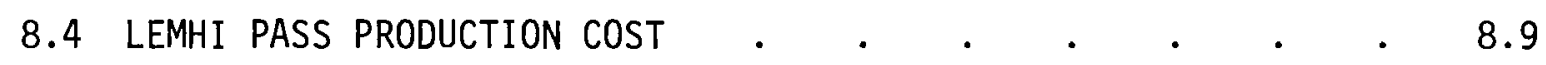

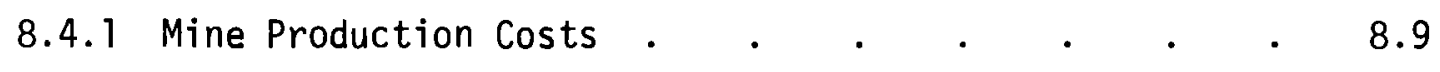

8.4.2 Mil1 Production Costs . . . . . . . . . . 8.10

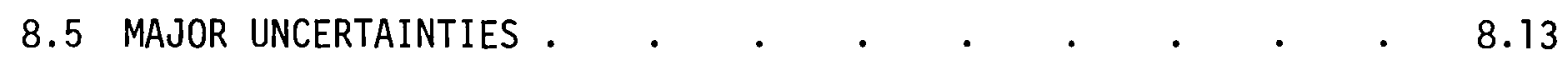

9.0 THORIUM PRODUCTION FROM HALL MOUNTAIN, IDAHO • • • • • • 9.1

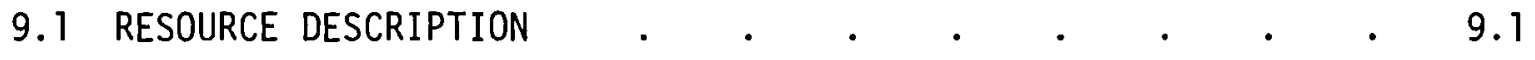

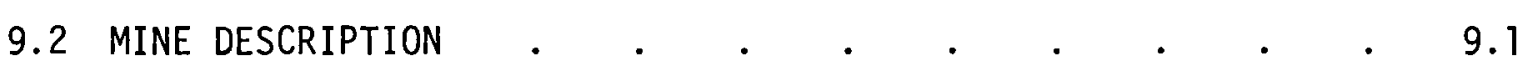

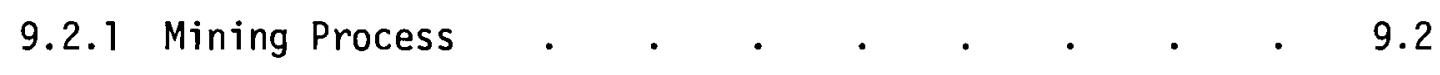




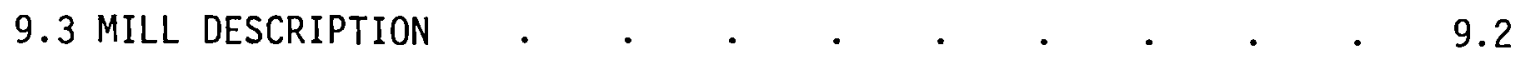

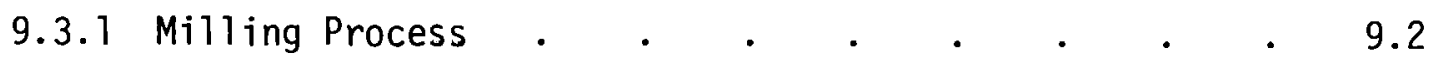

9.4 HALL MOUNTAIN PRODUCTION COSTS $\quad . \quad$. $\quad . \quad$. $\quad . \quad$. $\quad 9.2$

9.4.1 Mine Production Costs . . . . . . . . . . $\quad . \quad 9.3$

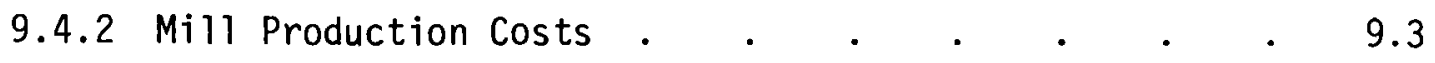

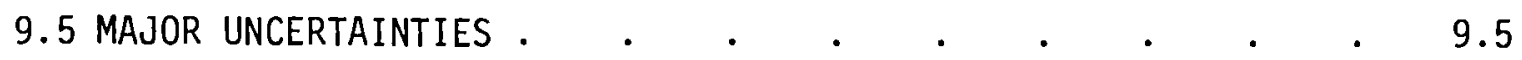

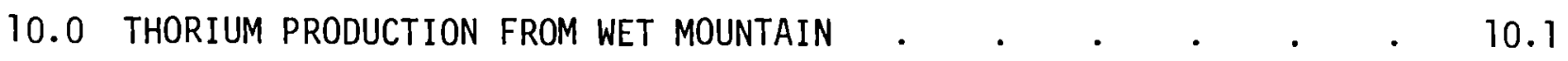

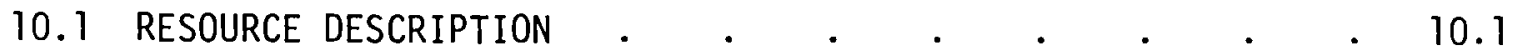

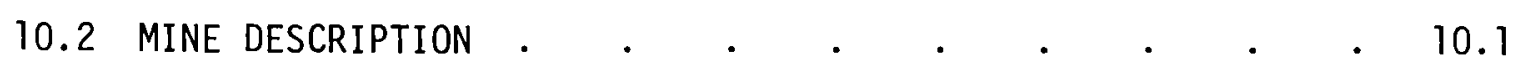

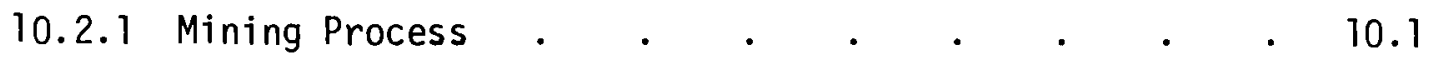

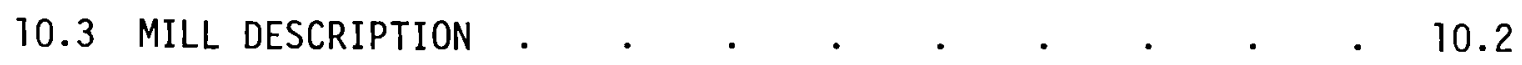

10.3.1 Milling Process $\quad . \quad$. $\quad . \quad . \quad . \quad . \quad 10.2$

10.4 WET MOUNTAIN PRODUCTION COSTS . $\quad . \quad$. $\quad . \quad$. 10.2

10.4.1 Mine Production Costs . . . . . . . 10.2

10.4.2 Mil1 Production Costs . . . . . . 10.3

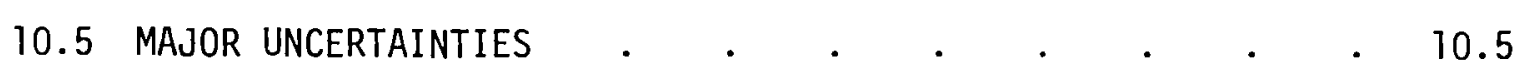

11.0 THORIUM PRODUCTION FROM PALMER, MICHIGAN . . . . . . . 11.1

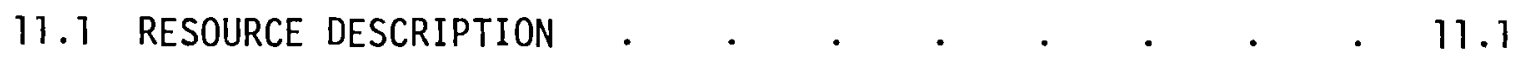

11.2 MINE DESCRIPTION

11.2.1 Mining Process . . . . . . . . . . 11.2

11.3 MILL DESCRIPTION

11.3.1 Milling Process . . . . . . . . . . . 11.3

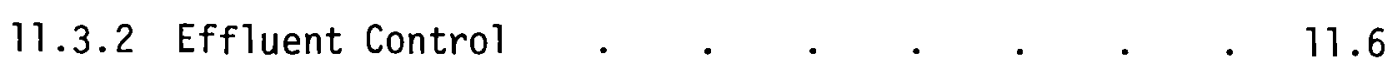

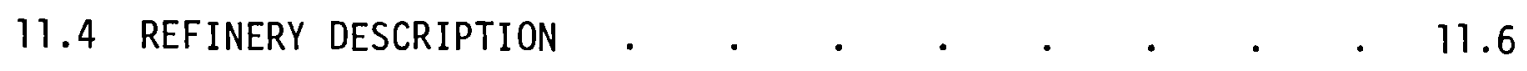

11.4.1 Refining Process . $\quad . \quad . \quad . \quad . \quad . \quad . \quad 11.7$ 
11.4 .2 Effluent Control . . . . . . . . . 11.11

11.4 .3 Sulfuric Acid Plant . . . . . . . . 11.11

11.5 PALMER, MICHIGAN PRODUCTION COSTS . . . . . . 11.11

11.5.1 Mine/Mi11 Production Costs . . . . . . 11.11

11.5 .2 Byproduct Credit . . . . . . . . 11.17

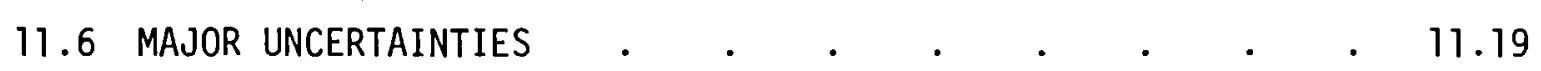

12.0 THORIUM PRODUCTION FROM BEAR LODGE, WYOMING • • • • • • 12.1

12.1 RESOURCE DESCRIPTION . . . . . . . . . . . . 12.1

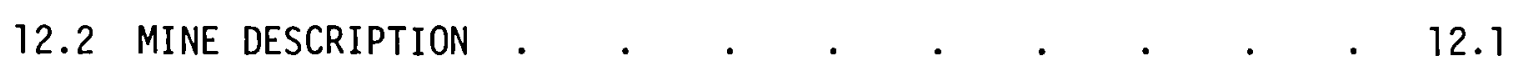

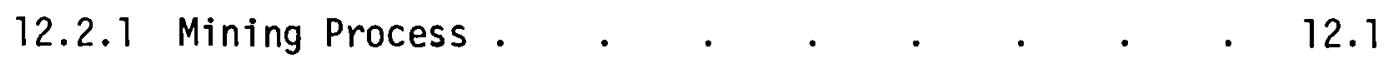

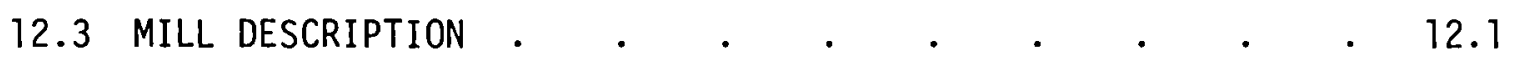

12.3.1 Milling Process . . . . . . . . 12.2

12.4 BEAR LODGE PRODUCTION COST • .

12.4.1 Mine Production Cost . . . . . . 12.2

12.4.2 Mi11 Production Costs . . . . . . 12.4

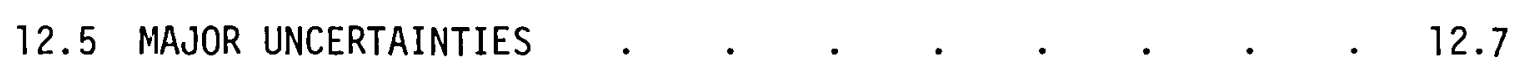

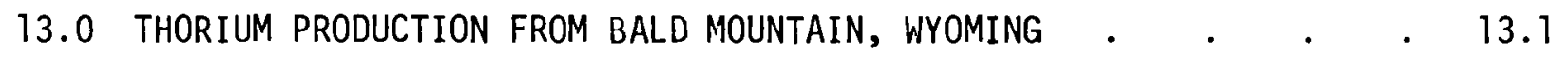

13.1 RESOURCE DESCRIPTION

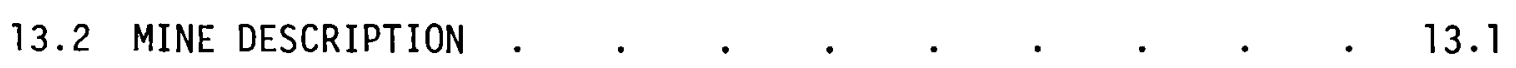

13.2.1 Mining Process . . . . . . . . . 13.1

13.3 MILL DESCRIPTION .

13.4 REFINERY DESCRIPTION . . . . . . . . . . . 13.2

13.5 BALD MOUNTAIN PRODUCTION COSTS • • • • .

13.5.1 Mine/Mil1 Production Costs . . . . . 13.2

13.5.2 Refinery Production Costs . . . . . . 13.4 


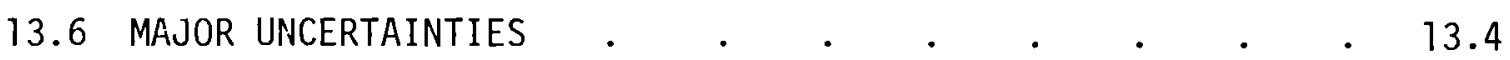

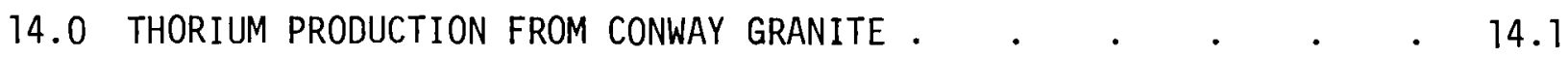

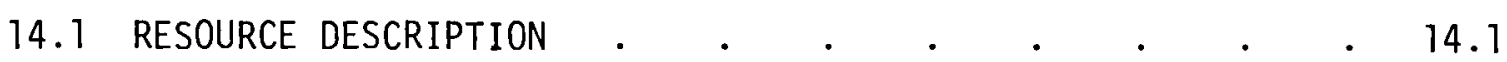

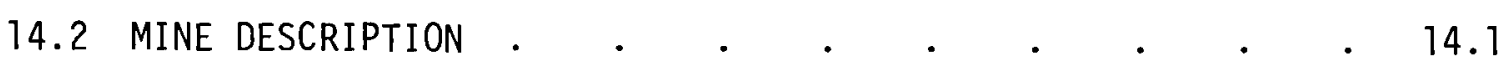

14.2.1 Mining Process . . . . . . . . . . . . 14.1

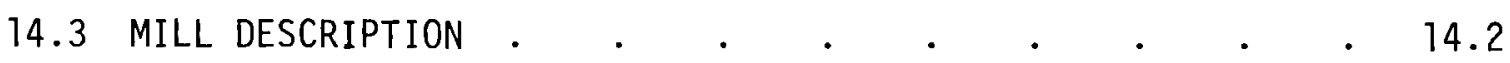

14.3.1 Milling Process . . . . . . . . . 14.2

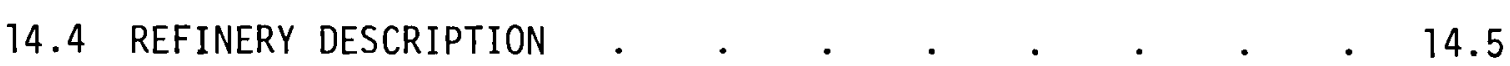

14.4.1 Uranium Recovery . . . . . . . . . . 14.5

14.5 CONWAY GRANITE PRODUCTION COST , . $\quad$. $\quad . \quad$. 14.5

14.5.1 Mine/Mill Production Costs . . . . . 14.5

14.5.2 Refinery Production Costs . . . . . . 14.9

14.5 .3 Byproduct Credit . . . . . . . . 14.10

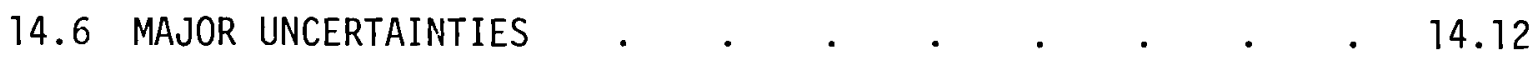

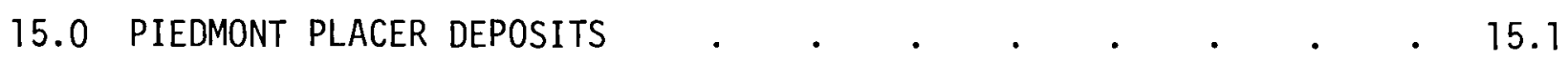

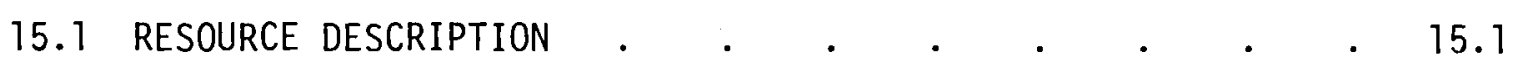

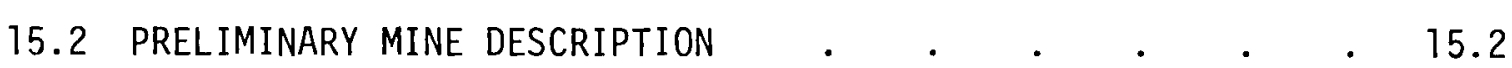

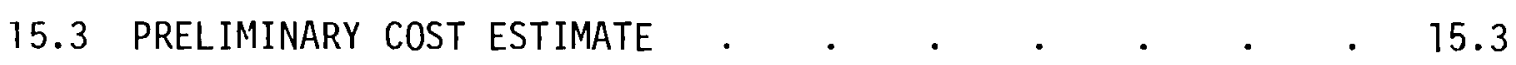

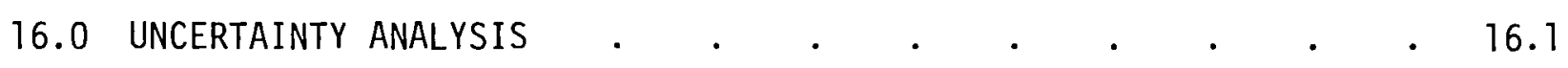

16.1 INTRODUCTION

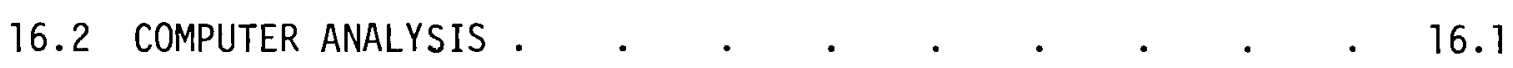

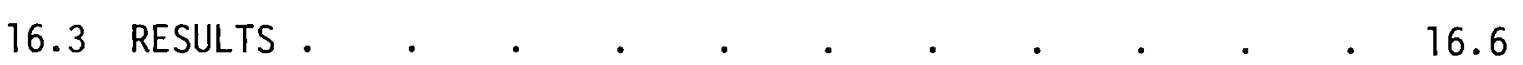

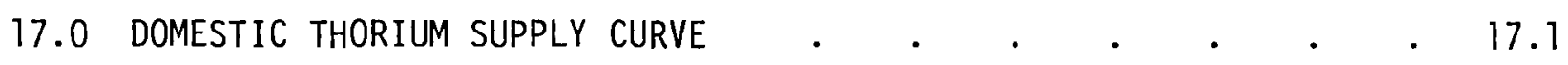

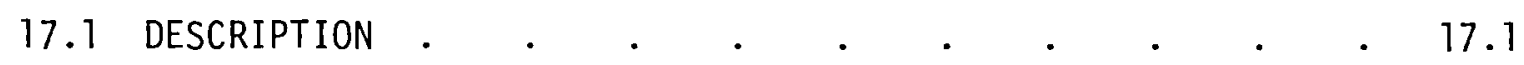

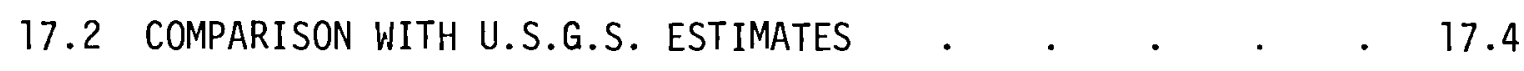




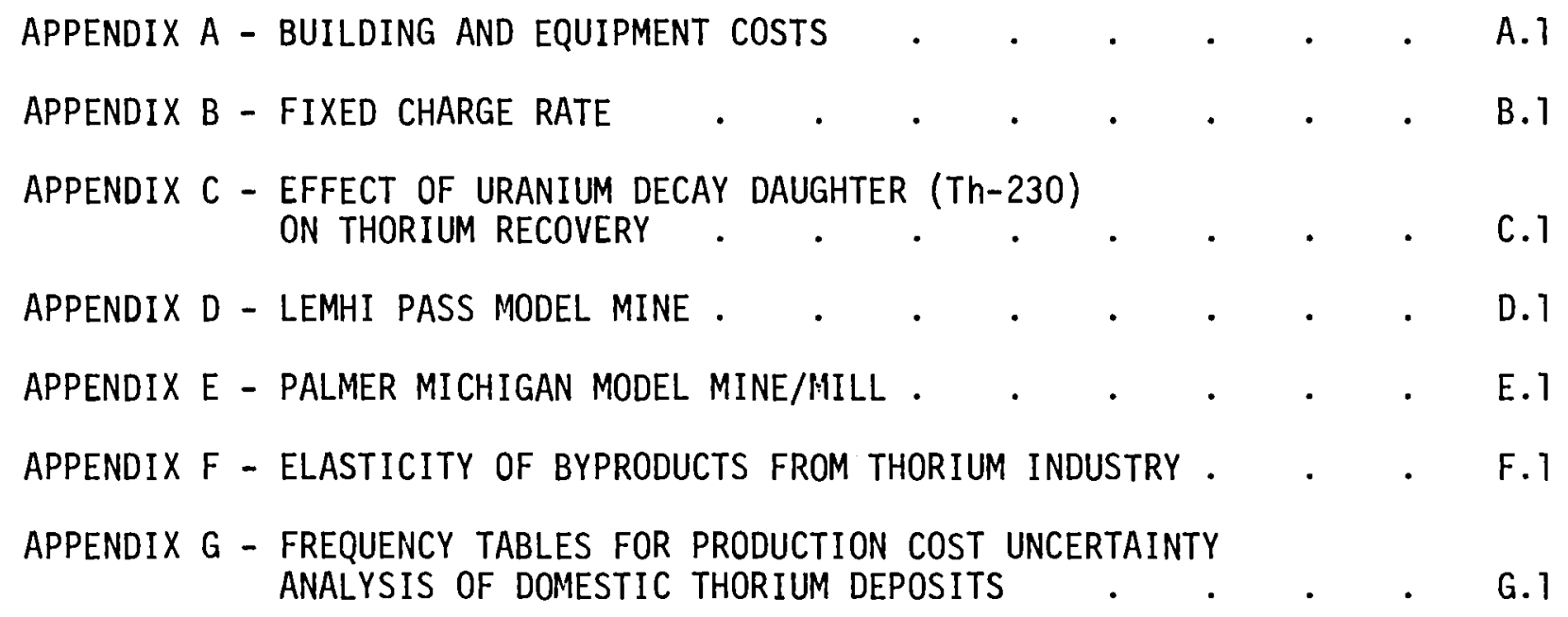



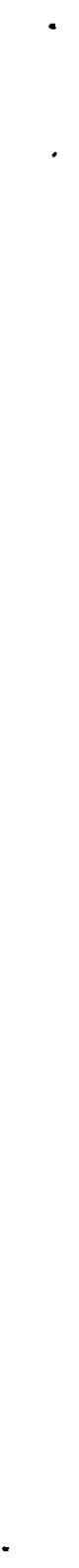


\section{TABLES}

4.1 Chemical Impurities in Nuclear Grade Thorium Oxide $\quad$ e $\quad$. $\quad 4.2$

4.2 Parasitic Neutron Absorbers in Nuclear-Grade

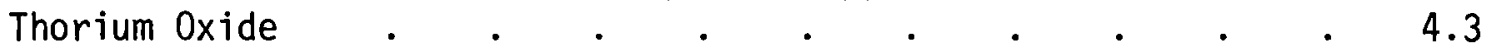

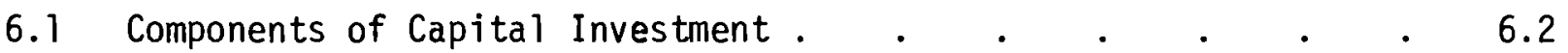

6.2 Estimation of Buildings and Equipment Cost

(Showing Individual Components) $\quad . \quad . \quad . \quad . \quad . \quad 6.2$

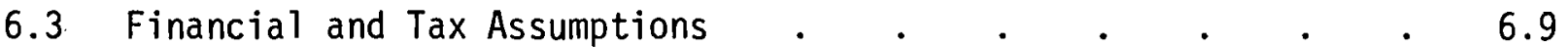

7.1 Stockpile Production Costs .

7.2 Stockpile Refinery Production Costs: Chattanooga

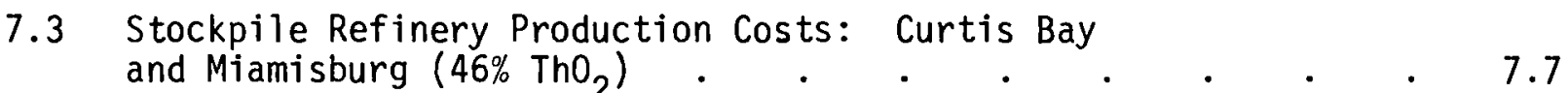

7.4 Stockpiles Refinery Production Costs: Fernald $\left(88 \% \mathrm{ThO}_{2}\right)$ • $\quad 7.7$

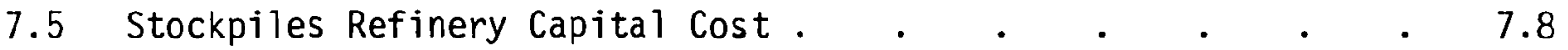

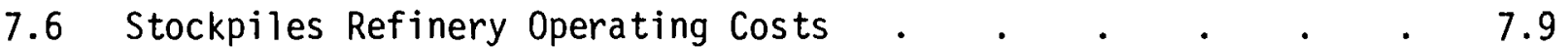

7.7 Stockpiled Thorium Reagent and Utilities Cost $. \quad . \quad . \quad$. 7.10

7.8 Stockpiles Annual Transportation Cost: $25 \% \mathrm{ThO}_{2} \quad$ - $\quad$ - $\quad$ - 7.10

\begin{tabular}{l}
7.9 Uncertainty Ranges for Factors Affecting Stockpile \\
Cost Estimates \\
\hline
\end{tabular}

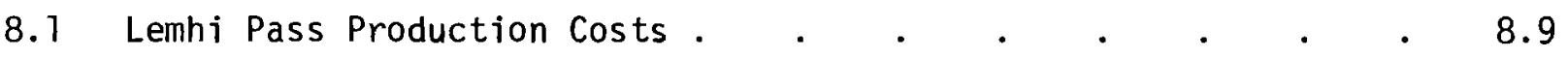

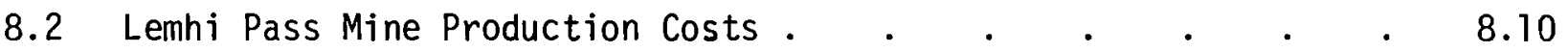

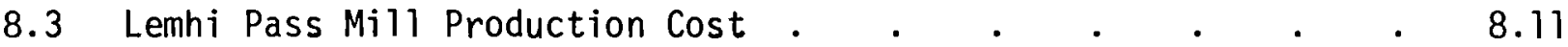

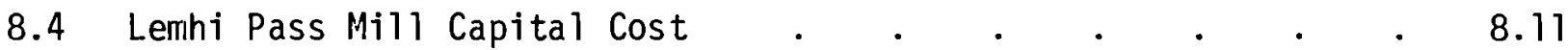

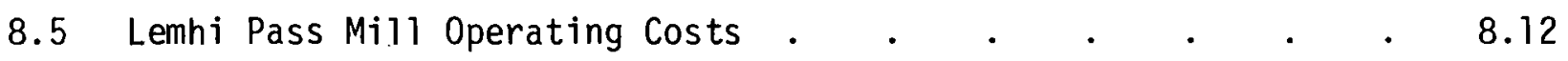

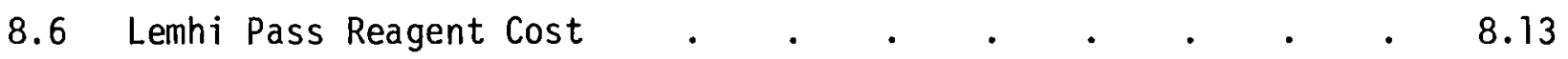

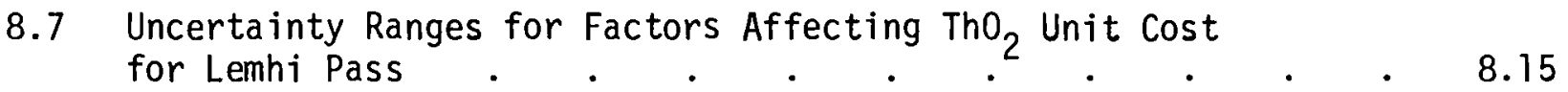




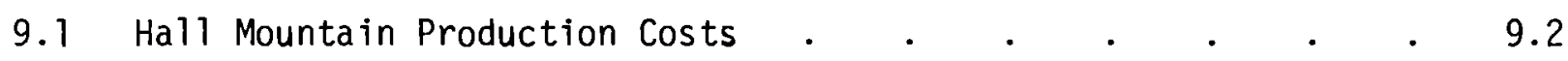

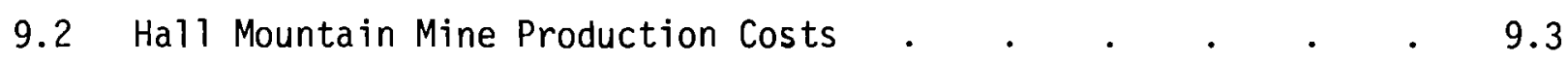

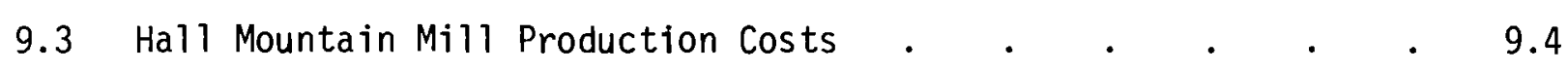

9.4 Hall Mountain Mill Capital Cost . . . . . . . . . . . 9.4

9.5 Hall Mountain Mill Operating Cost $\quad . \quad$. $\quad . \quad . \quad . \quad . \quad 9.5$

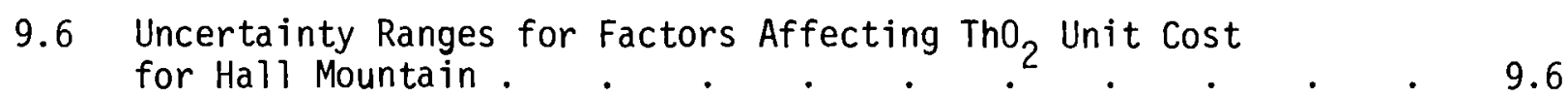

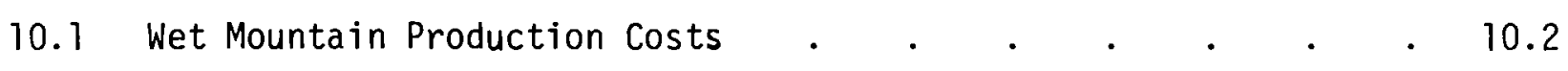

10.2 Wet Mountain Mine Production Costs . . . . . . . 10.3

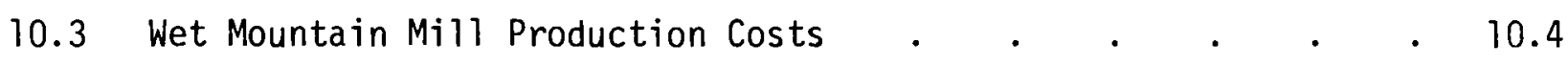

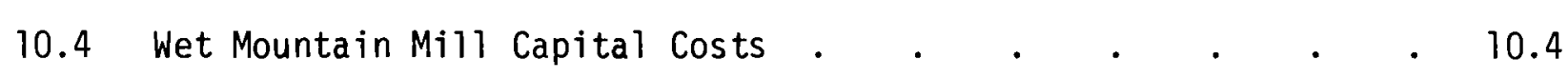

10.5 Wet Mountain Mill Operating Cost . $. \quad . \quad . \quad . \quad . \quad . \quad . \quad 10.5$

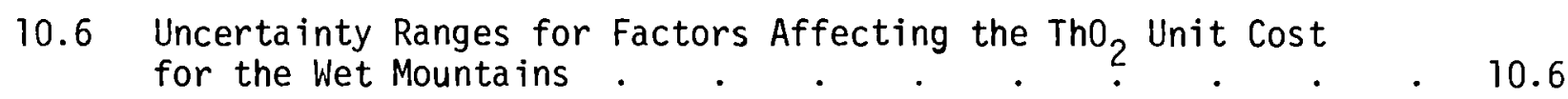

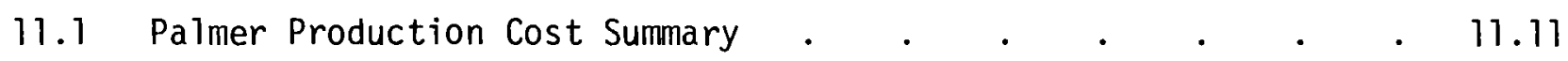

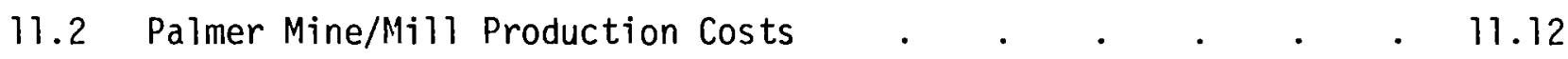

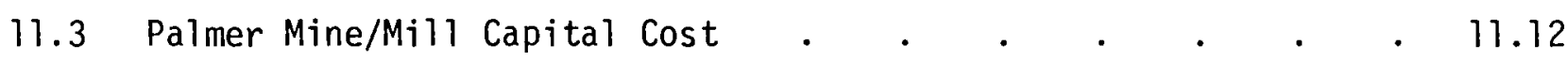

11.4 Palmer Mine/Mill Operating Costs . $. \quad . \quad . \quad . \quad . \quad . \quad 11.13$

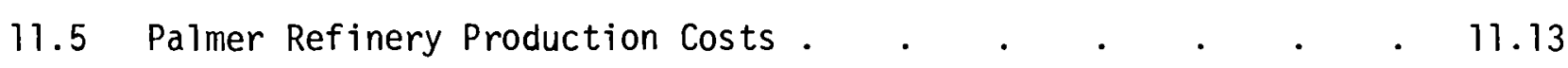

11.6 Palmer Refinery Capital Costs $\quad . \quad$.

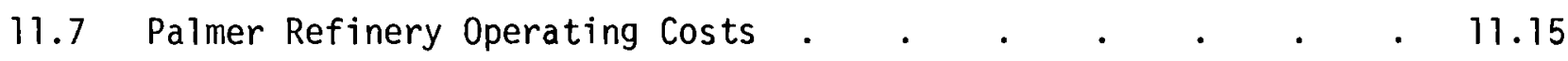

11.8 Palmer Reagent Consumption and Expense $\quad . \quad$. $\quad . \quad$. $\quad$. 11.16

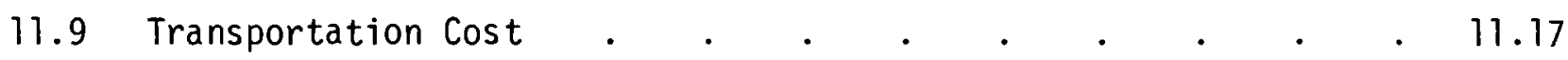

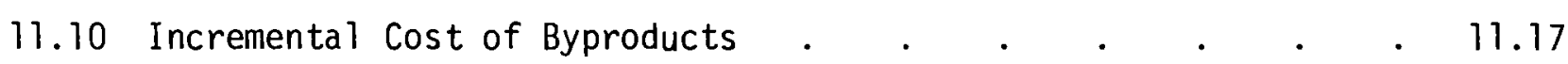

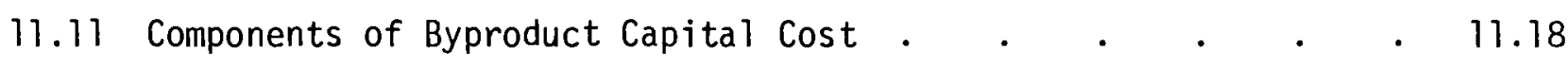

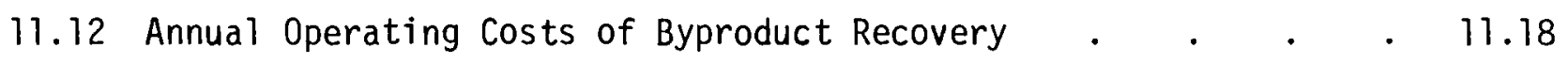


11.13 Uncertainty Ranges for Factors Affecting Th0 ${ }_{2}$ Unit Cost . . 11.20

12.1 Bear Lodge Production Cost Summary . . . . . . . 12.2

12.2 Bear Lodge Mine Production Costs . . . . . . . . 12.3

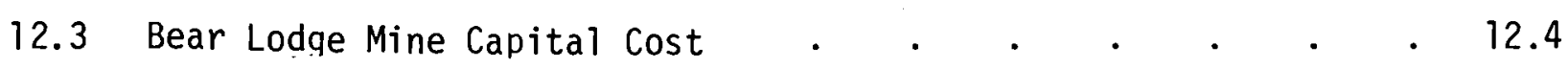

12.4 Bear Lodge Mine Operating Costs . . . . . . . . 12.4

12.5 Bear Lodge Mi11 Production Costs . . . . . . . . 12.5

12.6 Bear Lodge Mill Operating Costs . . . . . . . . . . 12.6

12.7 Reagent Consumption and Expense . . . . . . . . 12.6

Uncertainty Ranges for Factors Affecting Bear Lodge Cost . . 12.8
Estimates

13.1 Bald Mountain Production Cost Summary . . . . . . 13.2

13.2 Bald Mountain Mine/Mill Production Costs . . . . . 13.3

13.3 Bald Mountain Mine/Mill Capital Costs . . . . . . . 13.3

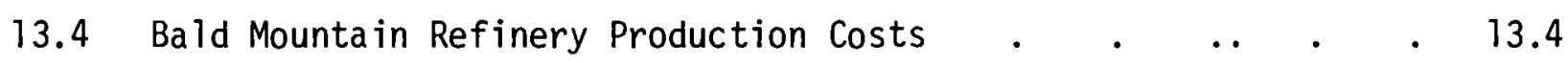

13.5 Uncertainty Ranges for Factors Affecting Th0 ${ }_{2}$ Unit Cost . . 13.5

14.1 Conway Granite Production Costs . . . . . . . . . $\quad$. 14.8

14.2 Conway Granite Mine/Mill Production Costs . . . . . . 14.8

14.3 Conway Granite Mine/Mill Capital Cost . . . . . . . . 14.9

14.4 Mill Operating Costs . . . . . . . . . . . . 14.9

14.5 Reagent Consumption and Expense . . . . . . . . 14.10

14.6 Utilities . . . . . . . . . . . . . . 14.10

14.7 Conway Granite Byproduct Capital Cost . . . . . . . 14.11

14.8 Conway Granite Byproduct Operating Cost . . . . . . 14.11

14.9 Reagent Consumption and Expense . . . . . . . . 14.11

14.10 Uncertainty Ranges for Factors Affecting Th0 $\mathrm{T}_{2}$ Unit Cost . . 14.13

16.1 Uncertainty Ranges $\mathrm{ThO}_{2}$ Unit Cost of Palmer, Michigan . . 16.2 
16.2 Uncertainty Analysis for Palmer, Michigan Deposit . . . 16.3

16.3 Frequency Distribution for Palmer, Michigan . . . . 16.5

16.4 Range of Unit Costs for Thorium Oxide . . . . . . . . 16.6

17.1 Summary of Development Costs for Domestic $\mathrm{ThO}_{2}$ Resources . 17.3

A-1.1 Stockpiled Thorium Buildings and Equipment Cost

for Refinery . $\quad . \quad$. . . . . . . . . . . A.1

A-1.2 Stockpiles Effluent Control Buildings and Equipment

Cost for Refinery. . . . . . . . . . . A.2

A-2.1 Lemhi Pass Buildings and Equipment Cost for Mill . . . A.3

A-2.2 Lemhi Pass Effluent Control Buildings and Equipment

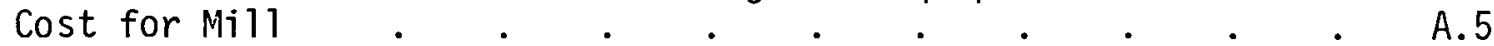

A-2.3 Lemhi Pass: Sulfuric Acid Plant Buildings and

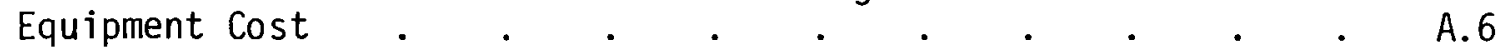

A-3.1 Palmer, Michigan Buildings and Equipment Cost

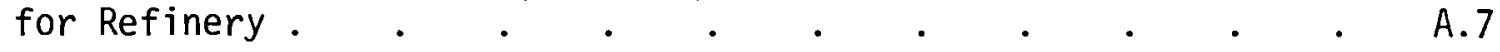

A-3.2 Palmer, Michigan Effluent Control Buildings and A.8

A-3.3 Palmer, Michigan Sulfuric Acid Plant Buildings and

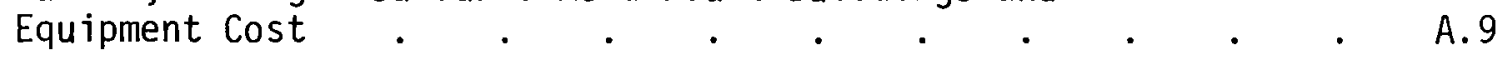

A-3.4 Palmer, Michigan: Byproduct Recovery Buildings and
Equipment for Refinery. . . . . . . A.10

C. 1 Th-230 Content in Domestic Ores . . . . . . . . . C.4

F.1 REO Content in Monazite . . . . . . . . . . . . F.5

F.2 Uses of Rare Earth Elements and Yttrium . . . . . . . F.8

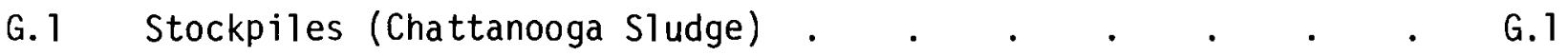

G. 2 Stockpiles (Curtis Bay--Miamisburg Sludge) . . . . . . G.2

G.3 Stockpiles (Fernald Sludge) . . . . . . . . . G.3

G.4 Hall Mountain . . . . . . . . . . . . . . . . G.4

G.5 Lemhi Pass (Stage 1) . 5 . 5 .

G.6 Lemhi Pass (Stage 2) . . . . . . . . . . . . . . . G.6 
G.7 Wet Mountain . . . . . . . . . . . . . . . G.7

G.8 Palmer, Michigan .

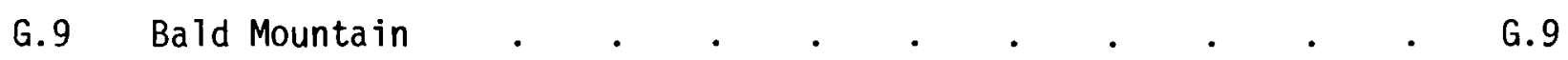

G.10 Bear Lodge--North Block . . . . . . . . . . . G.10

G.11 Bear Lodge--Central Block . . . . . . . . . . . . G.11

G.12 Bear Lodge--South Block . . . . . . . . . . . . G.12

G.13 Conway Granite . . . . . . . . . . . . . . . G.13 
. 


\section{FIGURES}

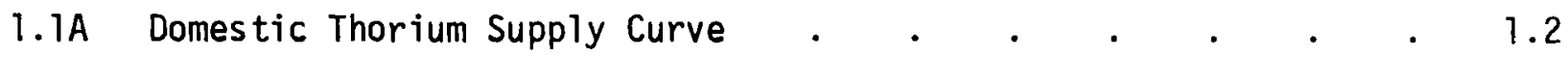

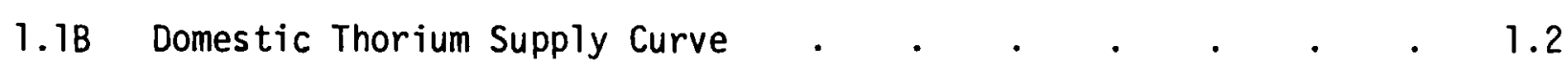

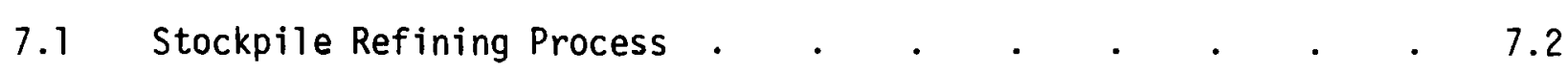

8.1 Lemhi Pass Milling/Refining Process . . . . . . . . . $\quad 8.5$

11.1 Palmer Michigan Mill $\quad . \quad$.

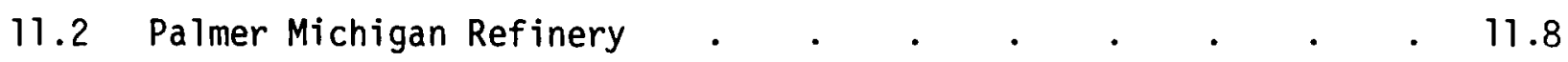

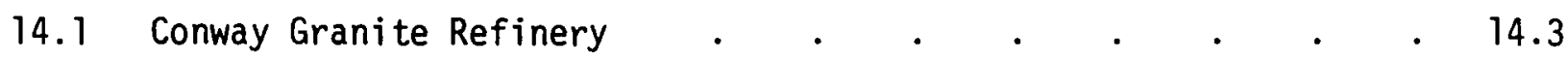

14.2 Conway Granite Refinery . . . . . . . . . . . 14.6

16.1 Distribution of Unit Cost for Palmer, Michigan . . . . 16.4

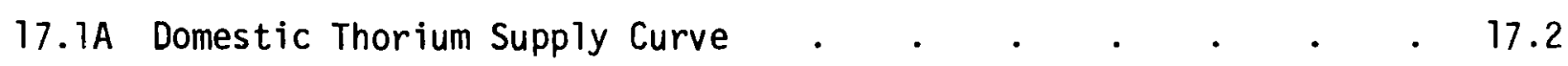

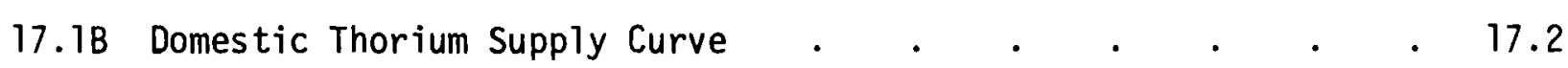





\subsection{SUMMARY}

Current interest in nonproliferation has prompted reassessment of the advantages of the thorium fuel cycle. However, a successful thorium program depends on resource availability, economic viability, and the environmental safety of not only the power plant, but also the associated mining, milling, and refining facilities. To determine the feasibility of the thorium fuel cycle, the supply curve for thorium oxide was developed for domestic thorium resources (see figures $1.1 \mathrm{~A}$ and $1.1 \mathrm{~B}$ ). The curve illustrates the relationship between production costs and quantity of thorium oxide available. A11 production costs are in 1978 dollars. Production cost figures include costs for baseline environmental control.

In the supply curve, the quantity of reserves and the most likely production cost is illustrated by a rectangular area on the supply curve for each deposit. A double arrow drawn perpendicular to the top of the rectangle

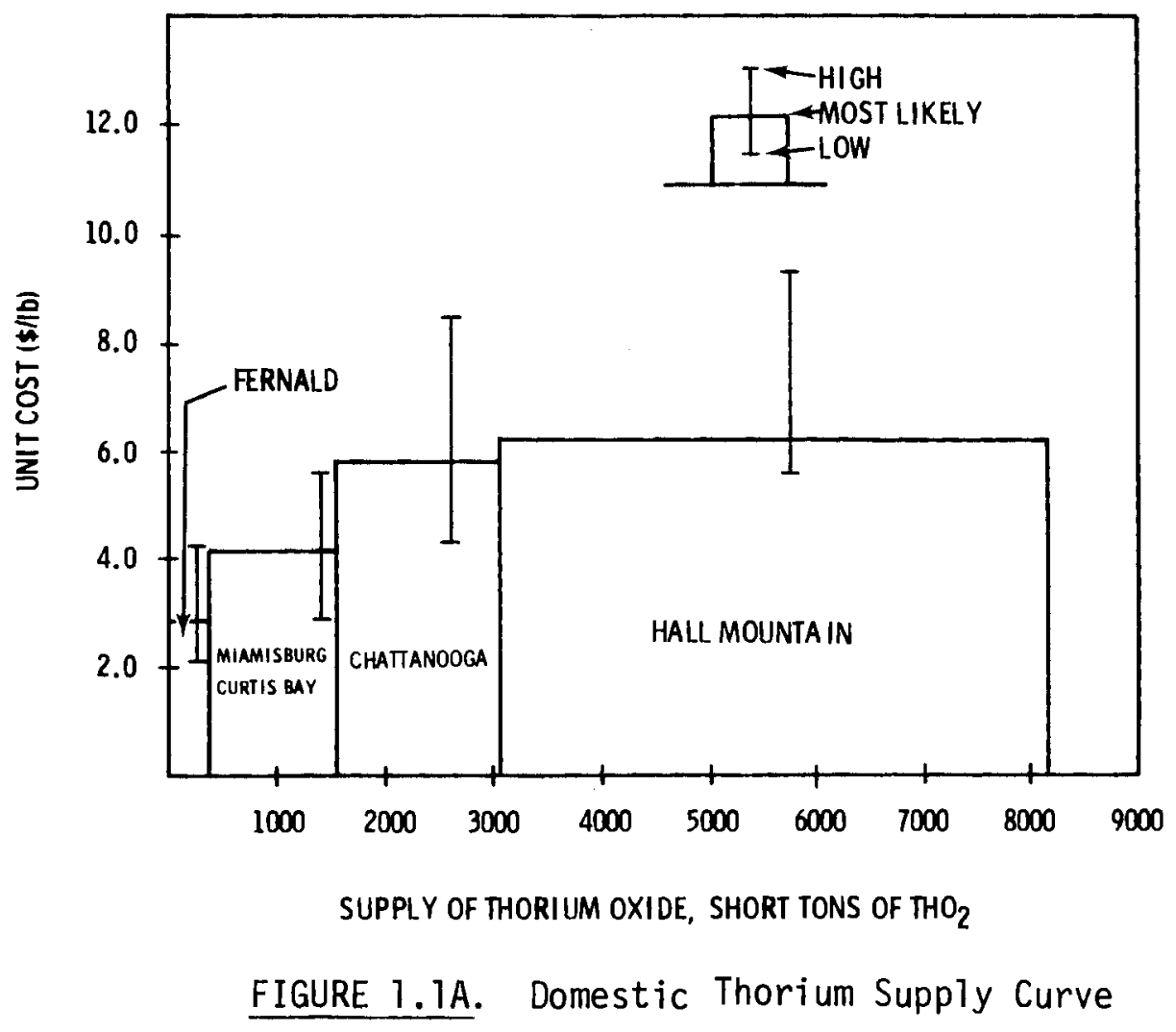




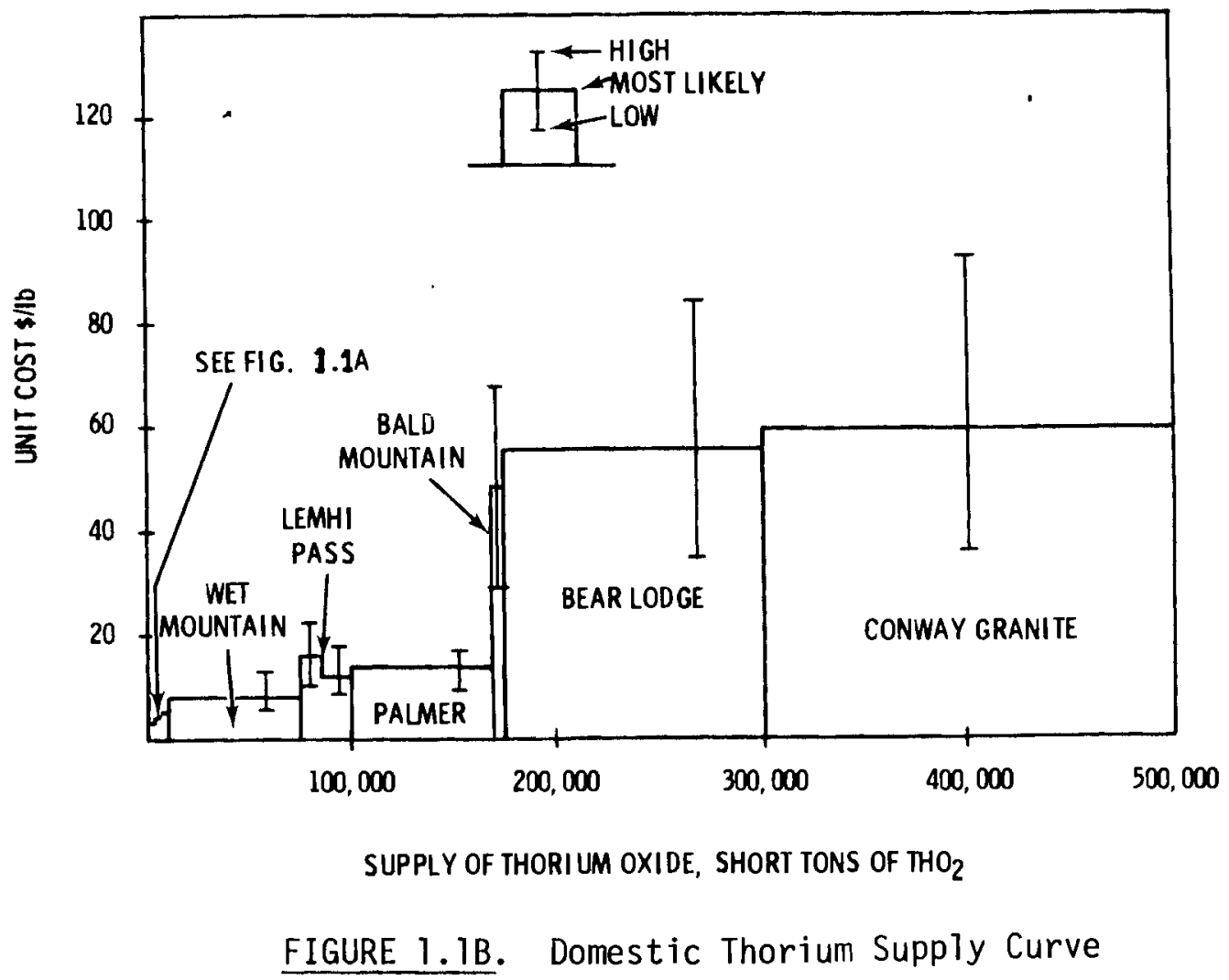

illustrates high and low cost estimates for each deposit. Deposits are arrayed by plotting production costs in increasing order except for Lemhi Pass. The Lemhi Pass deposit shows a decrease in cost because Lemhi Pass is mined in two stages. Costs for the first stage of mining are higher because a lower grade of ore is developed. As mining progresses, higher grades of ore are accessed (second stage) and production costs decrease.

The supply curve illustrates that sufficient amounts of thorium exist to supply a domestic thorium-reactor economy. Most likely costs of production range from $\$ 3$ to $\$ 60 / 1 \mathrm{~b} \quad \mathrm{ThO}_{2}$. Near-term thorium oxide resources include the stockpiles in Ohio, Maryland, and Tennessee and the thorite deposits at Hall Mountain, Idaho. Costs are under $\$ 10 / 1 \mathrm{~b}$ thorium oxide. Longer term economic deposits include Wet Mountain, Colorado; Lemhi Pass, Idaho; and Palmer, Michigan. Most likely costs are under $\$ 20 / 1 \mathrm{~b}$ thorium oxide. Long-term deposits include Bald Mountain, Wyoming; Bear Lodge, Wyoming; and Conway, New Hampshire. Costs approximately equal or exceed $\$ 50 / 1 \mathrm{~b}$ thorium oxide. 
The supply curve was developed by characterizing the principal identified domestic thorium resources by size, location, and type and grade of ore. Conceptual production processes were determined for the mining, milling and refining of reactor grade thorium oxide and costs of producing thorium oxide were estimated assuming current environmental control practices.

Thorium recovery processes are similar to uranium. After recovery by underground mining, vein deposits undergo crushing and grinding followed by acid dissolution, solvent extraction, precipitation, and calcination to reactorgrade thorium oxide. Disseminated and granitic deposits undergo chemical processing techniques similar to vein deposits but are mined by open-pit methods and preconcentrated by gravity and magnetic separation. The current source of thorium oxide, stockpiled throium sludge, is in a semi-processed state. It is refined by solvent extraction at Tennessee Nuclear Facilities, Jonesboro, Tennessee or National Lead Company of Ohio, Fernald, Ohio.

Production costs were determined from the capital and operating costs for each processing facility. The fixed charge rate method was utilized to annualize capital costs and to include state and local taxes, depreciation, interest, return on investment, and insurance in the production cost. Depletion and byproduct credit were also determined. Operating costs are comprised of direct and indirect expenses. Direct expenses include labor, maintenance and repairs, utilities, reagents, and supplies. Indirect expenses include payroll overhead, plant overhead, and administrative charges.

Uncertainty in cost estimates is determined using Monte Carlo simulation techniques. From estimates of high, most likely, and low values for plant capital and operating cost, product recovery, byproduct credit, plant size, and plant life, the range of production costs can be determined for each deposit. Costs for thorium including uncertainty range from $\$ 2.00 / 1 \mathrm{~b}$ to $\$ 88.00 / 1 \mathrm{~b}$ of $\mathrm{ThO}_{2}$.

In addition to developing the supply curve, this report identifies effluent releases from the development of various thorium resources. The environmental impact of thorium and costs of various levels of control will be evaluated in a subsequent report. 
. 


\subsection{INTRODUCTION}

The development of nuclear energy is subject to resource availability, economic viability, and political policy. A successful nuclear program depends on an acceptable integration of these factors. To aid in evaluating al ternative fuel cycles, data is necessary on the price and sources of nuclear material with time. The effect of policy alternatives on the economic viability of the proposed nuclear fuel cycle can then be evaluated.

In recent years, political opinion has prompted the reassessment of the thorium fuel cycle as an alternative source of power. In a nuclear reactor, thorium breeds the fertile isotope, U-233, rather than plutonium, which is bred in uranium fueled reactors. Either plutonium or uranium-233, depending on the fuel cycle, is separated from the irradiated fuel and mixed with natural or depleted uranium (U-238) to form new fuel. Conceivably, this nuclear fuel material could be diverted by terrorists or foreign governments and utilized for weapons manufacture. Unlike plutonium, however, the fissile isotope U-233 can only be separated from the depleted uranium by an expensive isotopic separations process.

The purpose of this report is to determine the possible range of costs to produce feedstock for fabrication of thorium-bearing fuels. This report derives the long-term supply curve for mining, milling, and refining reactorgrade thorium oxide. The supply curve is developed by first determining a maximum potential demand for thorium. Domestic thorium reserve estimates sufficient to meet this demand are identified based on available data from the U.S. Geological Survey and the U.S. Bureau of Mines plus reserve estimates generated during the course of the study by Pacific Northwest Laboratories operated for the Department of Energy by Battelle Memorial Institute (PNL). The thorium resources are characterized by size, location, type and grade of ore, etc. For each of the identified thorium resources, processes for mining through refining are determined and corresponding production costs are generated. The supply curve is obtained by plotting thorium oxide supply versus the cost of production. Energy costs can be calculated from the cost of the 
feedstock, the other costs of the fuel cycle, and the fuel exposures to determine the economic viability of the thorium fuel cycle.

In addition to developing the supply curve, this report identifies effluent releases from the development of various thorium resources. The environmental impact of thorium and costs of various levels of control will be assessed in a subsequent report. 


\subsection{MAXIMUM POTENTIAL DEMAND}

In developing the thorium supply curve, sufficient domestic resources are identified and characterized to meet future thorium oxide demands. The maximum thorium oxide demand, as shown below, is approximately 700,000 tons of thorium by the year 2070. This demand is an upper boundary; it is not a projection.

Maximum potential demand was calculated from growth estimates of total domestic nuclear generating capacity. The nuclear generating capacity estimates were derived by a computer code, ENFORM( 1$)$.

Thorium demand was determined by assuming a ten percent conversion of nuclear generating capacity to the thorium fuel cycle annually. Based on our assumption, all nuclear reactors would be converted to thorium by the year 2000, as shown on Table 3.1. Annual thorium demand is calculated by assuming 27 tons per year of thorium oxide are required per 1000 MWe of power. This thorium requirement assumes no recycle of irradiated thorium. From the annual demand, cumulative demand is calculated and maximum potential demand is determined.

TABLE 3.1. Potential Thorium Oxide Demands

\begin{tabular}{|c|c|c|c|c|}
\hline Year & $\begin{array}{c}\text { Total } \\
\text { Capacity } \\
\text { (MWe) } \\
\end{array}$ & $\begin{array}{l}\text { Thorium } \\
\text { Capacity } \\
\text { (MWe) } \\
\end{array}$ & $\begin{array}{l}\text { Annual } \\
\text { Thorium } \\
\text { Demand } \\
\text { (Tons/Yr) }\end{array}$ & $\begin{array}{c}\text { Cumulative } \\
\text { Thorium } \\
\text { Demand } \\
\text { (Tons) } \\
\end{array}$ \\
\hline $\begin{array}{l}1983 \\
1985 \\
1990 \\
1995 \\
2000 \\
2010 \\
2020 \\
2030 \\
2040 \\
2050 \\
2060 \\
2070\end{array}$ & $\begin{array}{r}88,160 \\
120,365 \\
184,080 \\
278,065 \\
380,000 \\
480,000 \\
447,149 \\
324,116 \\
248,000 \\
232,001 \\
213,203 \\
208,732\end{array}$ & $\begin{array}{r}8,816 \\
31,245 \\
110,385 \\
229,779 \\
380,000 \\
480,000 \\
447,149 \\
324,116 \\
248,000 \\
232,001 \\
213,283 \\
208,732\end{array}$ & $\begin{array}{r}238 \\
843 \\
2,980 \\
6,204 \\
10,260 \\
12,960 \\
12,073 \\
8,751 \\
6,696 \\
6,264 \\
5,758 \\
5,636\end{array}$ & $\begin{array}{r}238 \\
1,600 \\
11,889 \\
35,948 \\
79,627 \\
199,859 \\
325,237 \\
427,807 \\
502,804 \\
572,785 \\
631,501 \\
694,712\end{array}$ \\
\hline
\end{tabular}




\section{REFERENCES}

1. C.M Heeb, W.L. Purcel1, B.M. Cole, ENFORM: An Energy Information System, BNWL-2195, Battelle, Pacific Northwest Laboratories, Richland, WA 99352, March 1977. 


\subsection{PURITY OF FINAL THORIUM PRODUCT}

Since this report determines technology and costs of producing nuclear grade thorium oxide, we needed a set of nuclear specifications which satisfy the purity requirements for thorium used in thermal reactors. Currently, no American Standards and Testing Materials (ASTM) specifications exist for reactor-grade thorium oxide, although draft specifications have been prepared. Thus, we developed a set of purity standards which parallel the ASTM specifications for nuclear-grade uranium oxide. Using these standards as guidelines, processes for refining thorium oxide were designed which theoretically produce a satisfactory thorium product.

\subsection{DEFINITION OF REACTOR-GRADE THORIUM OXIDE}

A hypothetical standard for thorium oxide utilized for nuclear purposes is summarized in the following sections. Only those requirements which affect processing techniques are discussed.

\subsubsection{Chemical Requirements}

Thorium content, utilizing current processing techniques, is a minimum 99\% thorium oxide on a dry weight basis. Thus, a reactor specification of 99\% thorium oxide shall be assumed. Assuming ASTM specifications similar to uranium oxide, chemical impurities shall not exceed the individual element specification shown on Table 4.1 and the summation of impurities shall not exceed $1500 \mathrm{ppm}$.

\subsubsection{Nuclear Requirements}

In order to obtain a favorable neutron economy, reactor-grade thorium must be free from elements with high thermal neutron absorption cross-sections. For thermal reactor use, the total equivalent boron contributions (EBC) are utilized to determine acceptable levels of parasitic neutron absorbers. Assuming the same specifications exist for uranium oxide powder as for thorium oxide powder, the total EBC must not exceed $4.0 \mathrm{ppm}$ (Table 4.2). As with uranium oxide fuel, isotopic limits shall be specified by the purchaser. This is of special concern when dealing with thorium from ores associated with uranium (Appendix $\mathrm{C}$ ). 


\section{TABLE 4.1. Chemical Impurities in Nuclear Grade Thorium 0xide}

\begin{tabular}{|c|c|c|}
\hline Element & $\begin{array}{c}\text { Maximum } \\
\text { Concentratign } \\
\text { Limit ppm } \\
\end{array}$ & $\begin{array}{l}\text { Actua } 1^{b} \\
\text { Conc. ppm } \\
\end{array}$ \\
\hline Aluminum ${ }^{C}$ & 100 & $<5$ \\
\hline Carbon & 100 & $\mathrm{~N} / \mathrm{A}$ \\
\hline Calcium + Magnesium ${ }^{C}$ & 200 & $110+$ \\
\hline Chlorine + Flourine ${ }^{C}$ & 350 & $20+$ \\
\hline Chromium & 200 & $N / A$ \\
\hline Cobalt & 100 & $N / A$ \\
\hline Copper ${ }^{d}$ & 250 & 5 \\
\hline $\operatorname{Iron}^{e}$ & 250 & 1 \\
\hline Lead & 250 & $<5$ \\
\hline Manganese ${ }^{d}$ & 250 & 10 \\
\hline Molybdenum & 250 & N/A \\
\hline Nickel & 200 & 10 \\
\hline Nitrogen & 200 & N/A \\
\hline Phosphorus ${ }^{\mathrm{e}}$ & 250 & .12 \\
\hline Silicone & 200 & 60 \\
\hline Tantalum & 250 & $N / A$ \\
\hline Tin & 250 & $N / A$ \\
\hline Titanium $^{f}$ & 250 & .5 \\
\hline Tungsten & 250 & $N / A$ \\
\hline Vanadium & 250 & $\mathrm{H} / \mathrm{A}$ \\
\hline Zinc & 250 & $N / A$ \\
\hline Uranium $^{f}$ & 10 & .07 \\
\hline
\end{tabular}

a. Annual Book of ASTM Standards for "Nuclear-Grade Sinterable Uranium Dioxide Powder", Part 45, C753.

b. Actual measured impurity levels for thorium oxide obtained using solvent extraction methods of purification.

c. V. S. Yemel'Yanov and A. I. Yevstyukhin, The Metallurgy of Nuclear Fuel, Pergamon Press Ltd., Oxford, London, P. 407, 1969.

d. Prakesh, B. et al., Metallurgy of Thorium Production, Developments in Peaceful Applications of Nuclear Energy, No. 22, International Atomic Energy Agency, Vienna, P. 24, 1963.

e. R. J. Callow, The Industrial Chemistry of the Lanthanonons, Yttrium, Thorium and Uranium, Pergamon Press Ltd., Oxford, London, P. 182, 7967.

f. Estimate.

N/A Not available. 


\section{TABLE 4.2. Parasitic Neutron Absorbers in Nuclear-Grade Thorium 0xide}

\begin{tabular}{|c|c|c|c|c|c|}
\hline Element & $\begin{array}{c}\text { Absorption } \\
\text { Cross Section } \\
\text { (barns-2200 } \mathrm{m} / \mathrm{s})^{\sigma} a \\
\end{array}$ & $\begin{array}{l}\text { Atomic } \\
\text { Weight } \\
\end{array}$ & $\begin{array}{c}E B C \\
\text { Factor } \\
\end{array}$ & $\begin{array}{l}\text { Conc. in } \\
\mathrm{ThO}_{2} \mathrm{ppm}\end{array}$ & $\underline{E B C^{b}}$ \\
\hline Aluminum ${ }^{c}$ & .235 & 26.98 & .0001 & $<5$ & .0005 \\
\hline Barium & 1.2 & 137.34 & .0001 & & \\
\hline Boron ${ }^{c}$ & 759 & 10.81 & 1.0000 & .05 & .05 \\
\hline Cadmiumb & 2450 & 112.40 & .3104 & .63 & .196 \\
\hline Cesium & 30. & 132.91 & .0032 & & \\
\hline Chlorine $e^{e}$ & 33.2 & 35.45 & .0133 & $<20$ & .266 \\
\hline Chromium & 3.1 & 52.00 & .0008 & & \\
\hline Cobalt & 37.2 & 58.93 & .0090 & & \\
\hline Copper ${ }^{d}$ & 3.8 & 63.54 & .0009 & 5 & .0045 \\
\hline Dysprosium $^{C}$ & 930 & 162.50 & .0815 & .08 & .007 \\
\hline Europium ${ }^{\mathrm{C}}$ & 4400 & 151.96 & .4124 & .02 & .04 \\
\hline Gadol inium ${ }^{c}$ & 49000 & 157.25 & 4.438 & .12 & .53 \\
\hline Nafnium & 105 & 178.49 & .0084 & & \\
\hline Iron & 2.55 & 55.85 & .0007 & 1 & .0007 \\
\hline Lithium ${ }^{\mathrm{C}}$ & 71.0 & 6.939 & .1457 & $<.05$ & .35 \\
\hline Manganese $^{d}$ & 13.30 & 54.94 & .0034 & 10 & .034 \\
\hline Molybdenum & 2.70 & 95.94 & .0004 & & \\
\hline Nickel ${ }^{d}$ & 4.60 & 58.71 & .0011 & 10 & .011 \\
\hline Nitrogen & 1.85 & 14.01 & .0019 & & \\
\hline Phosphorous ${ }^{\mathrm{e}}$ & .19 & 30.97 & .0001 & 60 & .000 \\
\hline Samarium ${ }^{e}$ & 5820 & 150.35 & .5513 & $\therefore 12$ & .066 \\
\hline Silicon ${ }^{e}$ & .16 & 28.09 & .0001 & 60 & .006 \\
\hline Tantalum & 21 & 180.95 & .0017 & & \\
\hline Tin & .63 & 118.69 & .0001 & & \\
\hline Titanium $^{f}$ & 6.1 & 47.90 & .0018 & .5 & .0009 \\
\hline Tungsten & 18.5 & 183.85 & .0014 & & \\
\hline Vanadium & 5.06 & 50.94 & .0014 & & \\
\hline \multirow[t]{2}{*}{ Zinc } & 1.1 & 65.37 & .0002 & & \\
\hline & & & & TOTAL & $1.5 \overline{69} \mathrm{ug}$ \\
\hline
\end{tabular}

a Brookhaven National Laboratory Publication BNL-325, Second Edition, July, 1958 and Supplement No. 1, January, 1960, and Supplement No. 2, 1964-1966.

$b$ The EBC is calculated for each element as follows: where: $E B C$ of impurity, $u g / g=\left(A_{\text {impurity }}\right)$ (ug impurity/g thorium)

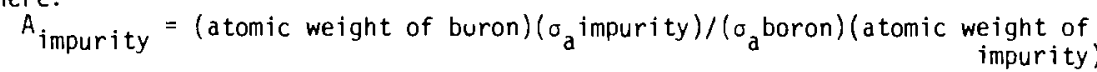
where:

$\sigma_{a}=2200 \mathrm{~m} / \mathrm{s}$ thermal neutron absorption cross section, barns.

For fast reactor use, the above EBC restrictions do not apply.

C V. S. Yemel Yyanov and A. I. Yevstyukhin, The Metallurgy of Nuclear Fuel, Pergamon Press Ltd., Oxford, London, P. 401, 1969.

d Prakesh, B. et al., Metallurgy of Thorium Production, Developments in Peaceful Applications of Nuclear Energy, No. 22, International Atomic Energy Agency, Vienna, P. 24, 1963.

e R. J. Callow, The Industrial Chemistry of the Lanthanonons, Yttrium, Thorium and Uranium, Pergamon Press Ltd., Oxford, Londor, P. 182, 1967.

$f$ Estimate 


\subsubsection{Physical Requirements}

Bulk density and particle-size requirement will probably be established. For purposes of this report, a particle size of less than 75um will be required along with an average particle size of less than loum. Bulk density shall be a minimum of $1.0 \mathrm{~g} / \mathrm{cm}^{3}$ as determined by the Scott Volumeter technique.

\subsection{ACTUAL PRODUCT PURITY}

In determining whether a product constitutes reactor-grade $\mathrm{ThO}_{2}$, major concern is with the removal of elements with high absorption cross-sections. Elements which cause the most problem are Gadolinium, Europium, Samarium, Cadmium, Dysprosium, Lithium, and Boron. This is a concern in LWR fuels.

For most processes in this study, adequate data on product purity is not available. Information on important impurities contained in thorium oxide from monazite sand is published, however. Data in Tables 4.1 and 4.2 indicates that thorium processed similar to methods conceptualized in this study meets conceptual specifications. Since ores other than monazite also utilize similar refining techniques, the end product should meet reactorgrade quality for all ores studied in this report. 


\subsection{THORIUM ORES AND THEIR PROCESSING TECHNOLOGY}

\subsection{CURRENT THORIUM INDUSTRY}

Currently, demand for thorium is primarily in the gas mantle industry. Other uses include magnesium-based high temperature alloys for aircraft and aerospace applications, in refractories, for chemical, electronic, and metallurgical applications, and in research. In 1977, ten tons of $\mathrm{ThO}_{2}$ was also used in two nuclear reactors: General Atomic's 330 MWe high temperature gas cooled reactor at Fort St. Vrain, Colorado and the Department of Energy's 50 MWe experimental light water breeder reactor at Shippingport, Pennsylvania. The price for thorium was $\$ 2.75 / 1 \mathrm{~b}$ of nitrate and $\$ 17.50 / 1 \mathrm{~b}$ of nuclear grade $\mathrm{ThO}_{2}$ in $1977^{(1)}$.

Monazite sands feedstocks are utilized to obtain $\mathrm{ThO}_{2}$. Australia, India, Brazil, and Malaysia supply about $81 \%^{(2)}$ of the annual U.S. monazite demand. Monazite is produced domestically as a byproduct of heavy mineral production by Humphrey's Mining Company located in Florida. The cost for monazite in 1977 was approximately $\$ 164 /$ ton $^{(1)}$.

Domestically, monazite is processed primarily for rare earths by Davison Chemical Division of W. R. Grace and Company, Chattanooga, Tennessee. The monazite is treated with caustic soda and the digested solution is neutralized with hydrochloric acid. The thorium-bearing sludge is precipitated and stored in a pond. The rare earths are concentrated and sold in the form of rare earth chlorides. Current thorium processing capacity is approximately 250 tons/year $\mathrm{ThO}_{2}$ byproduct ${ }^{(2)}$.

Commercial refining facilities include Tennessee Nuclear Specialties which processes thorium sludge for nuclear purposes utilizing solvent extraction with TBP and oxalate precipitation. According to plant management, the capacity of the plant is about $700 \mathrm{1b} /$ day of $\mathrm{ThO}_{2}$. The plant currently produces 4 batches/yr of $\mathrm{ThO}_{2}$ at $5000 \mathrm{lb} / \mathrm{batch}(20,000 \mathrm{lb} / \mathrm{yr})$. The plant reportedly is in operation two 5 -day weeks per batch or $8 \mathrm{wks} / \mathrm{yr}^{(2)}$.

National Lead Company of Ohio (NLO), a Department of Energy facility, al so has the capability of processing thorium sludges and producing 
reactor-grade $\mathrm{ThO}_{2}$. NLO utilizes solvent extraction with DAAP (diamyl-amyl phosphonate) to purify thorium. The thorium mixture is then precipitated using ammonium hydroxide. Current thorium processing capacity is approximately $1000 \mathrm{~kg} /$ day.

\subsection{FUTURE THORIUM INDUSTRY}

Today domestic thorium production is only about 60 to 100 tons per year, (2) but future nuclear requirements might increase demand drastically. More widespread production of thorium-bearing minerals will then be necessary. And a new industrial structure will evolve to process thorium from various domestic resources. The price of thorium oxide will be dictated by the costs of exploiting now undeveloped reserves.

In order to clarify the discussion of future industries, a broad overview of the likely processing methods and costs is presented in this section. A hypothetical structure of the thorium industry is formulated which provides a basis for cost analysis.

\subsubsection{Stockpile Processing Stream}

Thorium is available in a semi-processed state from both government and industrial stockpiles. Stockpiles include the W. R. Grace pond in Chattanooga, Tennessee and government stocks in Curtis Bay, Maryland; Miamisburg, Ohio; and Fernald, Ohio. (Data on Curtis Bay is dated. Last report indicates the pond was bulldozed over.) A refining process is used to recover thorium from the stockpiles. The conceptual refinery uses solvent extraction to purify the thorium. The thorium is then precipitated as an oxalate and calcined. Reactorgrade $\mathrm{ThO}_{2}$ is produced. Production costs are calculated to range from approximately $\$ 3.00 / 1 \mathrm{~b}$ to $\$ 6.00 / 1 \mathrm{~b}$ of $\mathrm{ThO}_{2}$.

\subsubsection{Thorite Processing Stream}

Thorite-bearing vein deposits are some of the highest grade domestic sources of thorium. Any large-scale demand for thorium will certainly result in the exploitation of these resources.

Thorium is reported in at least seventeen vein districts in the United States. Larger, better known districts include 1) Lemhi-Pass Idaho-Mont., 
2) Wet Mountains. Colo., 3)Powderhorn, Colo., 4) Hall Mountain, Idaho, 5) Bear Lodge, Wyo. and 6) Mountain Pass, Calif. This study evaluates production costs for the Lemhi Pass and Wet lountains deposits since they contain eighty-seven percent of total reserves and probable potential resources for vein deposits. The Hall Mountain deposit was also included because of the extremely high tenor of the ore and its importance as a near-term potential source of thorium. Diamond Creek, Bear Lodge, Mountain Pass, and Powderhorn deposits were not evaluated in this study because of the small quantities of reserves available from these districts.

To determine costs, a model underground mine was developed based on the thorite deposits at Lemhi Pass. The mining methods used include resuing and cut and fill stoping depending on vein width. The mine model was also adapted to the Hall Mountain and Wet Mountains deposits.

The conceptual thorite milling process was based on a laboratory model developed by the U.S. Bureau of Mines ${ }^{(3)}$. Thorite is milled by grinding the ore and leaching with acid. After solvent extraction and ammonium hydroxide precipitation, the precipitate is calcined, producing reactor-grade $\mathrm{ThO}_{2}$ powder. Mills are located near the mines in order to minimize transportation costs. Production costs range from $\$ 6.00 / 1 \mathrm{~b}$ to $\$ 16.00 / 1 \mathrm{~b} \mathrm{ThO} \mathrm{T}_{2}$. Costs including uncertainty range from $\$ 5.00 / 1 \mathrm{~b}$ to $\$ 23.00 / 1 \mathrm{~b} \mathrm{ThO}_{2}$.

\subsubsection{Monazite Conglomerate Processing Stream}

In conglomerates, monazite is dispersed in rock. Thus, the ore must be ground to release the monazite mineral. The two principal deposits are Palmer, Michigan and Bald Mountain, Wyoming. The conglomerate monazite is refined much like monazite from placer sands, but mining and milling are quite different. Production costs are estimated to range from $\$ 14.00$ to $\$ 50.00 / 1 b$ of $\mathrm{ThO}_{2}$.

Three facilities are required to process the conglomerates--a mine, a mil1, and a refinery. A conceptual open pit mine model was developed to determine costs for the Palmer, Michigan deposit. This model was then adapted to the Bald Mountain deposit. Conceptual milling and refining processes were also determined. The ore is sent to a mill located at the mine site. In the mill 
the ore is crushed and ground. After gravity and magnetic separation, a monazite concentrate is obtained. The concentrate is sent to a nearby refinery where it is mixed with acid to dissolve the thorium. The thorium is removed from the acid solution by solvent extraction. After treatment with caustic soda, the thorium hydroxide is dried, calcined to the oxide, and packaged. The product is reactor-grade $\mathrm{ThO}_{2}$ powder.

\subsubsection{Carbonatite Processing Stream}

Identified carbonatite districts include Magnet Cove, Arkansas; Iron Hill, Colorado; Elk Creek, Nebraska; and Mountain Pass, California. Little data exists on the Magnet Cove, Mountain Pass, and Elk Creek deposits. The Iron Hill deposit is too low-grade to be economically mined for thorium alone. However, Iron Hill also contains significant amounts of niobium, uranium, and rare-earth oxides which could be recovered as byproducts. The economic effectiveness of byproduct recovery depends on the extent the saleable materials occur together in the ore. For example, niobium is contained solely in the pyrochlore. Minerals that potentially contain thorium, uranium, and rare earths include pyrochlore, bastneasite, and monazite. Until more data is available on the feasibility of obtaining a thorium concentrate that also contains a high content of byproducts, an accurate cost estimate for a multiproduct thorium facility is difficult to determine.

\subsubsection{Monazite Sand Processing}

Monazite-bearing heavy mineral deposits occur as beach and stream placer sands. The deposits include the Piedmont Placers in North and South Carolina. In these deposits the thorium-bearing monazite sand represents less than one percent of the placer sands; consequently, large amounts of material must be mined to recover a relatively small amount of monazite. The monazite sand usually occurs in conjunction with other valuable heavy mineral sands such as ileminite, rutile, zircon, columbite, and euxenite. In addition, monazite contains rare earths which are potentially salable byproducts. Estimated costs for producing $\mathrm{ThO}_{2}$ from these placers are more than $\$ 100 / 1 b$. Thus, these placers are not economical to exploit within the time frame of this study. 
Beach Placers in Florida and California are too low-grade to be economically mined for thorium alone. Thorium can only be produced as byproduct. The amount of thorium produced from beach placers will demand entirely on the market for rare earths. Costs for developing thorium from these resources a byproduct is reflected in the cost of developing the Chattanooga, Tennessee sludgepile.

Disseminated deposits include Conway Granite of New Hampshire; Bear Lodge Mountains, Wyoming; and Powderhorn district, Colorado. Resource calculations for these deposits are highly speculative. Because these deposits are important as long-term resources of thorium, the two largest deposits were included in this study. This includes the Conway Granites and the Bear Lodge Mountains.

\subsubsection{Disseminated Deposit Processing Stream}

Conway granite is a large, but expensive, source of thorium. Conway gran$i$ te has a relatively high concentration of thorium ( $50 \mathrm{ppm})$. The difficulty in mining, crushing, and acid leaching granite results in high capital and operating costs. Conway granite contains low concentrations of uranium (9 ppm) which could be recovered and sold to reduce the cost of the thorium.

While granite has not been mined commercially, the Department of Energy has extensively studied the processes necessary for mining and refining granite. Design and cost estimates for developing granite mining and refining facilities are taken from Department of Energy documents $(4,5)$. Production costs are estimated to range from $\$ 50.00 / 1 \mathrm{~b}$ to $\$ 60.00 / 1 \mathrm{~b} \mathrm{Th}_{2}$.

The conceptual granite processing stream consists of an open pit mine, a mill, and a refinery. The mill is located near the mine. The ore is crushed, ground and leached with acid. After a solvent extraction and treatment with caustic soda, a thorium/uranium concentrate is obtained. This concentrate is shipped to a refinery where the uranium is removed and the thorium is further purified by another solvent extraction procedure.

Bear Lodge is a large source of thorium located in Wyoming. Principal identified thorium bearing minerals are brockite, thorite, and monazite. Only 
the thorite mineral would be attacked by the dilute acid leach utilized to recover thorium. Thus the resulting low thorium recovery considerably reduces the economic attractiveness of this deposit.

The deposit is mined similar to the Palmer, Michigan deposit using open pit methods. Thorium ore is crushed, ground and submitted to a dilute sulfuric acid leach. After solvent extraction and ammonium hydroxide precipitation, the precipitate is calcined producing reactor $\mathrm{ThO}_{2}$. A central mill is located near the three potential open pit mines at Bear Lodge. 


\section{REFERENCES}

1. Martha L. Kahn, "Thorium: A New Optimism for Use in Nuclear Reactors". Engineering and Mining Journa 1, 179(3): 133-134, March 1978.

2. W. I. Enderlin, An Assessment of U.S. Domestic Capacity for Producing Reactor Grade Thorium Oxide and Controlling Associated Wastes and Effluents. PNL 2593, 49 pp., February 1978.

3. S. R. Borrowman and J. B. Rosenbaum, Recovery of Thorium from Ores in Colorado, Idaho and Montana. BuMines, RT 5916, 35 pp., 1962.

4. F. J. Hurst, D. J. Crouse, and K. B. Brown, Recovery of Thorium and Uranium from Granitic Rocks. ORNL-392, Oak Ridge National Laboratory, Oak Ridge, TN, 84 pp., October 1966.

5. F. J. Hurst, et al., Estimated Costs for Recovery of Thorium and Uranium. ORNL-3928, Oak Ridge National Laboratory, Oak Ridge, TN, 28 pp., November 1966. 


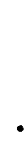




\subsection{PRODUCTION COST MODEL}

The objective of the cost model is to derive production costs of $\mathrm{ThO}_{2}$ for ores in this study. The cost model applies primarily to thorium processing facilities; however, selected elements are also applied to the mining costs determined by a consulting firm. All costs are in 1978 dollars and cost indices for escalation were determined from the U.S. Department of Labor and Statistics.

Production costs for all facilities are determined from estimates of capital and operating costs. The following equation is used:

$$
\left.P C=O P C+\Sigma\left[D C I_{i} \times F C_{i}\right)+\left(O T_{j} \times F C_{j}\right)\right]-D P
$$

where:

$$
\begin{aligned}
P C= & \text { annual production costs } \\
O P C= & \text { annual operating costs } \\
D C I_{i}= & \text { depreciable capital investment of class } i \text { where class } i \text { refers to } \\
& \text { all assets with the same depreciable life } \\
\mathrm{FC}_{\mathbf{i}, j}= & \text { fixed charge rate applicable to class } i \text { or } j \\
O \mathrm{TH}_{\mathbf{j}}= & \text { non-depreciable capital investments } \\
\mathrm{DP}= & \text { depletion allowance }
\end{aligned}
$$

The annual production cost obtained above is divided by the annual production of thorium oxide.

\subsection{CAPITAL COST MODEL}

Capital investments are required for the mine, mill, and refinery. Major elements of capital cost are shown in Table 6.1. Depreciable capital investments refer to assets which depreciate with use. Nondepreciable assets include land and working capital.

\subsubsection{Buildings and Equipment Cost}

In this study, buildings and equipment capital costs are calculated from the purchased equipment cost (Table 6.2). Overhead expenses for installation, service facilities, land, various engineering and construction 


\title{
TABLE 6.1. Components of Capital Investment
}

\author{
Buildings and Equipment cost \\ Main Plant \\ Effluent Control \\ Auxiliary Plant \\ Contingency \\ Tailings Pond (a) \\ Environmental Impact \\ Exploration (a) \\ Feasibility Study(a) \\ Development \\ Spare Parts Inventory \\ Access Road (a) \\ Total Depreciable Capital Investment \\ Total Land Cost \\ Working Capital \\ TOTAL CAPITAL INVESTMENT
}

\section{TABLE 6.2. Estimation of Buildings and Equipment Cost (Showing Individual Components)}

\section{Component}

Purchased Equipment

Field Erection

Foundations

Piping - Chuting

Electrical

Instrumentation

Buildings

Site Preparation

Service Facilities

Land

Physical Plant Cost

Engineering and Construction

Direct Plant Cost

Contractor's Fee

Total Plant Cost

Land (Subtract from Plant cost)

TOTAL BUILDINGS AND EQUIPMENT COST
Bas is

Design Estimate

$14 \%$ of Purchased Equipment Cost

$12 \%$ of Purchased Equipment Cost

$22 \%$ of Purchased Equipment Cost

$19.5 \%$ of Purchased Equipment Cost

$5 \%$ of Purchased Equipment Cost

$35 \%$ of Purchased Equipment Cost

$5 \%$ of Purchased Equipment Cost

$55 \%$ of Purchased Equipment Cost

$6 \%$ of Purchased Equipment Cost

$25 \%$ of Physical Plant Cost

$5 \%$ of Direct Plant Cost 
costs, and the contractor's fee are determined as a percentage of the costs of the processing equipment. As shown on Table 6.2, nondepreciable land costs are subtracted from the total plant costs to obtain a buildings and equipment cost. The buildings and equipment cost is derived for the: (1) main processing plant, (2) effluent control facilities, and (3) auxiliary plants. The buildings and equipment cost is included in the capital cost shown on Table 6.1 and derived in the following sections.

\subsubsection{Purchased Equipment Cost}

One of the major capital costs is equipment. The amount and size of equipment was determined from conceptual flow diagrams, material and energy balances, and reasonable design assumptions. Process equipment cost was obtained from vendor estimates, costs of similar equipment, and industrial estimating guides $(1)$.

\subsubsection{Equipment Installation}

Equipment installation includes costs for field erection, foundations, piping and chuting, electrical work and instrumentation. Field erection includes costs for transportation to the site and installation labor, and is estimated at $14 \%$ of the purchase cost. The cost for foundations and supports is estimated at $12 \%$ of the purchased equipment cost and includes the cost for concrete and other materials.

The cost for piping and chuting covers valves, fittings, pipe, supports, chutes and labor. Piping for raw materials, intermediate products, steam, water, air, sewer, and others is included in the estimate. Process plant piping is assumed to be $22 \%$ of the purchased equipment cost.

Electrical installation consists of: (1) power wiring, (2) lighting, (3) transformation and service, and (4) instrument and control wiring. Costs result from labor, and materials and are estimated at $19.5 \%$ of the purchase equipment cost.

Instrumentation includes instrument costs, expenses for auxiliary equipment, installation labor, and materials. For this study, instrumentation is estimated at $5 \%$ of the purchase equipment cost. 


\subsubsection{Butldings}

The cost for bulldings includes costs for labor, material, supplies, and costs for installation of plumbing, heating, lighting, and ventilation. It is estimated at $35 \%$ of the purchase equipment cost.

\subsubsection{Site Preparation}

At $5 \%$ of the purchased equipment cost, this includes costs for yard improvements such as fencing, grading, roads, sidewalks, railroad sidings and landscaping .

\subsubsection{Service Facilities}

Service facilities cost includes utilities for supplying steam, water, power, compressed air, and fuel. Also included are facilities for waste disposal, fire protection, first aid, and cafeteria equipment. This is approximately $55 \%$ of the purchased equipment cost .

\section{1 .1 .6 Land}

Land costs include actual acreage along with accompanying surveys and fees. Land is assumed to be $6 \%$ of the purchased equipment cost. Since land is not depreciable, it is treated separately from the buildings and equipment cost.

\subsubsection{Engineering and Construction}

This category includes charges for design, field supervision, construction labor, and inspection. A percentage of $25 \%$ of the physical plant cost is used in this estimate.

\subsubsection{Contractor's Fee}

For this study the contractor's fee is estimated at $5 \%$ of the direct plant cost.

\section{1 .2 Contingency}

To compensate for design errors or changes, unpredictable events, and other unforeseen expenses, this factor is included in the estimate of capital investment and is $15 \%$ of the direct plant cost ${ }^{(2)}$. 


\subsubsection{Tailings Pond}

Tailings ponds are comprised of embankments placed on the ground surface that are required to retain slurries of waste and water. With serious radioactive pollutants such as thorium and uranium, a clay core dam is necessary to control seepage and allow water to evaporate.

Tailings pond cost includes factors for land, tailings pumps, site preparation, and engineering construction fees, tailings decommissioning costs, and spray equipment to control leach dust. Reclamation costs have not been included.

\subsubsection{Environmental Impact Assessment}

The assessment of the environmental situation at the proposed site is an important factor and should also be included in the estimate of capital cost. The cost includes charges for legal counsel, public hearings and environmental studies. The cost is estimated to be in the range of $\$ 50,000$ to $\$ 100,000$ for a 200 tpd mil1 ${ }^{(2)}$. For simplicity, our study shall assume a cost of $\$ 100,000$ for environmental assessment unless better data is available from the Lemhi Pass or Palmer, Michigan models (Appendixes $D$ and $E$ ).

\subsubsection{Feasibility Study}

Feasibility studies are conducted before a program begins. Perspective markets for the product are analyzed, laboratory data is determined, and process methods are selected. After capital and operating cost estimates are determined, project feasibility can be evaluated.

Cost for feasibility studies would, of course, vary from site to site. However, for simplicity, feasibility study costs for facilities (except the mines) are estimated at $\$ 100,000^{(3)}$.

\subsubsection{Exploration}

Exploration costs for mine developments are incurred which determine the extent, amount, location, grade, or quality of the mineral deposit. These costs include expenses for land acquisition, core drilling, assaying, engineering fees, geological fees, exploratory shafts, pits, drifts, etc. 
Exploration costs are very site specific. They are determined for Lemhi Pass, Idaho and Palmer, Michigan deposits. Depending on expected mining methods, the costs are adapted to other deposits in this study.

\subsubsection{Development}

Development costs include all expenses incurred when making the ore body accessible. This includes expenses for shafts, raises, all mine headings, and depreciation on equipment used for such work. This cost varies from site to site and is determined simtlarly to exploration costs.

\section{1 .8 Access Road}

The cost for access roads is site dependent. For simplicity, access roads are estimated at $\$ 100,000^{(3)}$.

\subsubsection{Total Land Cost}

The summation of land costs for the main plant, auxiliary plant, and effluent control equipment is called the total land cost.

\subsubsection{Working Capital}

Working capital includes money invested in for: (1) raw materials and supplies, (2) inventory, (3) materials-in-process, (4) accounts receivable, (5) cash on hand, and (6) accounts and taxes payable. Working capital is assumed to be approximately $15 \%$ of the fixed capital investment ${ }^{(2)}$.

\subsection{OPERATING COST MODEL}

The unit cost of $\mathrm{ThO}_{2}$ production is determined from the annual operating costs. Operating costs include operating labor, supervisory and clerical labor, maintenance and repair, utilities, operating supplies, laboratory charges, chemicals and solvents, and plant and administrative overheads. The basis for estimating these components is discussed below.

\subsubsection{Operating Labor}

Operating labor is estimated from data from a similar industry or from the labor requirements for process equipment operation ${ }^{(1)}$. Wage rates, based on data from the U.S. Department of Labor ${ }^{(4)}$, are assumed to be $\$ 8.06 / \mathrm{hr}$. unless otherwise specified. 


\subsubsection{Direct Supervisory and Clerical}

The cost for direct supervisory and clerical is assumed to be about $15 \%$ of the cost for operating labor.

\subsubsection{Maintenance and Repairs}

These expenses include the cost for labor, materials and supervision. The total plant cost per year for maintenance and repairs shall be assumed equal to $6 \%$ of the capital investment ${ }^{(5)}$.

\section{2 .4 Utilities}

The cost of utilities includes the costs for steam, electricity, fuel oil, and water. The electricity, fuel oil, and water are purchased, but steam is produced on site. Steam costs would be included in charges for fuel oil and water.

Electric power was determined from process equipment requirements. A power factor of .90 and a distribution efficiency of .9 were also assumed. Power cost is assumed to be $\$ .03 / \mathrm{kWh}$.

Fuel oil demand for space heating and process equipment is also calculated. A cost of \$0.50/gal. for No. 6 fuel oil was assumed.

Water demand is determined from a material balance around the facility. The cost of water is assumed to be $\$ .05 / 1000$ gallons for city water, or $\$ .15 / 1000$ gallons for well water. The type of water depends on the proximity to an urban area.

\subsubsection{Operating Supplies}

Operating supplies include such items as charts, lubricants, janitor supplies, test chemicals, etc. The annual cost for operating supplies is about $15 \%$ of cost for maintenance and repairs.

\subsubsection{Laboratory Charges}

The cost of laboratory tests and labor is taken as 15\% of the operating labor cost ${ }^{(5)}$. This cost is necessary to insure proper control of product quality. 


\subsubsection{Chemicals and Solvents}

Chemicals and solvent requirements are determined from material balances for each specific facility obtained from published data on chemical prices.

\subsubsection{Plant Overhead}

Plant overhead includes costs for plant upkeep and overhead, payroll overhead, packaging, medical services, safety and protection, restaurants, recreation, salvage, laboratories, and storage facilities. Plant overhead is assumed to be $60 \%$ of cost for operating labor, supervision, and maintenance.

\subsubsection{Administrative Overhead}

Administrative costs include costs for executive salaries, clerical wages, legal fees, office supplies, and communications. It is assumed to be $15 \%$ of costs for operating labor, supervision, and maintenance ${ }^{(5)}$.

\subsection{FIXED CHARGE RATES}

A fixed charge rate method is used to simplify the discounted cash flow calculations (see Appendix B). It converts depreciable capital investment into an equivalent annual revenue requirement. Rather than calculate a year by year cash flow, a single fixed charge rate is assumed to apply over the life of the facility. The fixed charge rate includes provisions for capital recovery, bond interest, return on equity, federal income tax, state income tax, property tax and property insurance.

The fixed charge rate was calculated for the facilities assuming they are owned and operated by a mining or chemical processing company. For such a company, the financial and tax data in Table 6.3 was assumed. The fixed charge rate was calculated according to the procedure described in Appendix $B$. Fixed charge rate varies with plant lifetimes. For non-depreciable assets such as land and working capital, a fixed charge rate of $10 \%$ was assumed. 
TABLE 6.3. Financial and Tax Assumptions

$\begin{array}{lc}\text { Capitalization } & \\ \text { Debt } & 24 \\ \text { Equity } & 76 \\ \text { Bond Interest Rate } & 8 \\ \text { Return on Equity } & 15 \\ \text { Federal Income Tax } & 48 \\ \text { State Income Tax } & 7 \\ \text { Property Tax } & 2.5 \text { of capital cost } \\ \text { Property Insurance } & .5 \text { of capital cost } \\ \text { Mine-Mill Life } & \text { Site Dependent } \\ \text { Depreciation } & \text { Sum of the years digits }\end{array}$

\subsection{DEPLETION ALLOWANCE}

Depletion is a periodic non-cash expense charged to income to reflect the decline in the value of property. In this study, the percentage method is utilized to calculate depletion. Thorium production qualifies for a depletion allowance of $22 \%$ of the gross revenues. According to Internal Revenue Code 613 (b), the depletion allowance cannot exceed $50 \%$ of income. For the purposes of this study, we assumed that this income test would be met and the full depletion allowance would apply.

The depletion allowance is applicable to the gross revenue which comes from the extraction of thorium ores and minerals in the ground. Only revenues from the mining and concentrating processes would probably qualify for the depletion allowances. The depletion allowance is treated as an expense for income tax purposes which reduces the tax liability.

\subsection{BYPRODUCT CREDIT}

For many of the ores in this study, byproducts are produced during some stage of processing. In order to determine byproduct credit, the amount of byproducts, the market price of byproducts, and the incremental cost of byproduct production must be specified. The amount of byproducts is determined by 
the composition of the ore and the efficiency of recovery processes. The current market price of byproducts is avallable in literature and is utilized when potential byproduct production is small relative to conventional supplies. When byproduct production will saturate the market, a credit of less than current market value is assumed. (See Appendix F.) The incremental cost of byproduct production is determined from associated capital and operating costs.

The reduction in thorium production costs resulting from a byproduct credit is determined by Equation 6.1. Byproduct revenues less the incremental byproduct production costs are divided by the thorium production to determine the byproduct credit. If the incremental cost of recovering byproduct is greater than the revenue obtained, no byproduct credit will be considered.

$$
B C=[(\text { AMBY } \times \text { MP })-I N C] / T P
$$

where:

$$
\begin{aligned}
B C & =\text { Byproduct credit } \\
\text { AMBY } & =\text { Amount of byproducts } \\
M P & =\text { Price of byproducts } \\
I N C & =\text { Incremental cost of byproduct production } \\
T P & =\text { Thorium production }
\end{aligned}
$$

\subsection{ROYALTIES}

Since royalties affect market price rather than production costs, no provisions for royalties shall be included in this study.

\subsection{TRANSPORTATION}

According to Title 49 in the Code of Federal Regulations, natural thorium constitutes a low specific activity radioactive material and must be transported in exclusive use vehicles and packaged in strong, tight packages that allow no leakage. Costs for this study were determined assuming railroads are utilized for long distance shipping. Trucks ship thorium to nearby facilities and to and from the rail car. 


\subsection{SCALING FACTOR}

A scaling factor is required to adjust one set of estimates to a different design size. Use of a scaling factor is illustrated by the following equation:

$$
c_{n}=r^{s} c
$$

where:

$$
\begin{aligned}
C_{n} & =\text { new plant cost } \\
r & =\text { ratio of new to previous capacity } \\
s & =\text { scaling factor } \\
c & =\text { previous plant cost. }
\end{aligned}
$$

The scaling factor for mining is estimated to be approximately .75 . This number is derived from data collected by the U.S. Bureau of Mines ${ }^{(6)}$. The scaling factor for chemical plants is estimated to be approximately $.7(7)$. The scaling factors are limited to no more than tenfold changes in plant capacity. 


\section{REFERENCES}

1. H.G. Blecker, T.M. Nichols, Capital and Operating Costs of Pollution Control Equipment Modules, EPA-R5-73-023b, Report to the Environmental Protection Agency by Icarus Corp., Silverspring, MD, 183 pp. July 1973.

2. F.T. Davis, W.H. Yarroll, The Economics of Small Milling Operations, Mineral Industries Bulletin, Vol. 18, No. 6, Colorado School of Mines, Golden, C0, 15 pp., November 1975.

3. D.W. Gentry, M.J. Hrebar, Procedure for Determining Economics of Smal1 Underground Mines, Mineral Industries Bulletin, Vol. 19, No. 1, Colorado School of Mines, Golden, C0, 183 pp., 1976.

4. Employment and Earnings, Vo1. 24, No. 11, United States Dept. of Labor, Bureau of Statistics, November, 1977.

5. Peters, M. S. and K. D. Timmerhaus, Plant Design and Economics for Chemical Engineers, McGraw-Hi11 Book Company, New York, NY, 1968.

6. Chemical and Operating Cost Estimating System Handbook, Prepared for the United States Dept. of Interior, Bureau of Mines, by STRAAM Engineers, Inc., Arcadia, CA, 374 pp., July 1978.

7. Robert H. Perry and Cecil H. Chilton, Chemical Engineers Handbook, 5th Ed., McGraw-Hil1 Book Company, New York, N.Y., pp. 25-16 and 25-17, 1973. 


\subsection{STOCKPILES}

\subsection{RESOURCE DESCRIPTION}

The primary industrial stockpile for thorium is owned by W. R. Grace and Company in Chattanooga, Tennessee. Thorium sludge is currently stockpiled at a rate of 250 tons/yr and an estimated backlog of 1500 tons of $\mathrm{ThO}_{2}$ equivalent is contained in the ponds. The thorium sludge is reported to contain $25 \% \mathrm{ThO}_{2}$ and some uranium (assumed to be $\sim 1 \%$ ) $(1)$.

Government stockpiles exist at Curtis Bay, Maryland, Miamisburg, Ohio, and Fernald, Ohio. These stockpiles are primarily in the form of thorium nitrates. Approximately 800 tons of $\mathrm{ThO}_{2}$ equivalent are stored at Curtis Bay, Maryland, and another 400 tons of $\mathrm{ThO}_{2}$ equivalent are located in Miamisburg, Ohio. These stockpiles are assayed at approximately $46 \% \mathrm{ThO}_{2}$. Another 360 MT of sludge which contains $88 \% \mathrm{ThO}_{2}$ equivalent is stored in Fernald, Ohio.

\subsection{REFINERY DESCRIPTION}

Because stockpiled material is in a preprocessed state, only a refining facility would be necessary to develop the resource. The conceptual stockpile refinery is located near Chattanooga, Tennessee. The refinery utilizes Grace sludge as primary feedstock. However, government stockpiles are also processed to keep the refinery operating at rated capacity.

At rated capacity, the refinery processes $600 \mathrm{1b} / \mathrm{hr}$ of sludge and operates 22 hours/day, 350 days/yr for 10 years. The process is assumed to recover $95 \%$ of the thorium in the sludge.

\subsubsection{Refining Process}

The refining process utilizes nitric acid to dissolve the sludge. The thorium-bearing acid solution is purified by solvent extraction with tributyl phosphate in kerosene. The thorium is then precipitated using oxalic acid and calcined. The refining process is illustrated in Figure 7.1. 


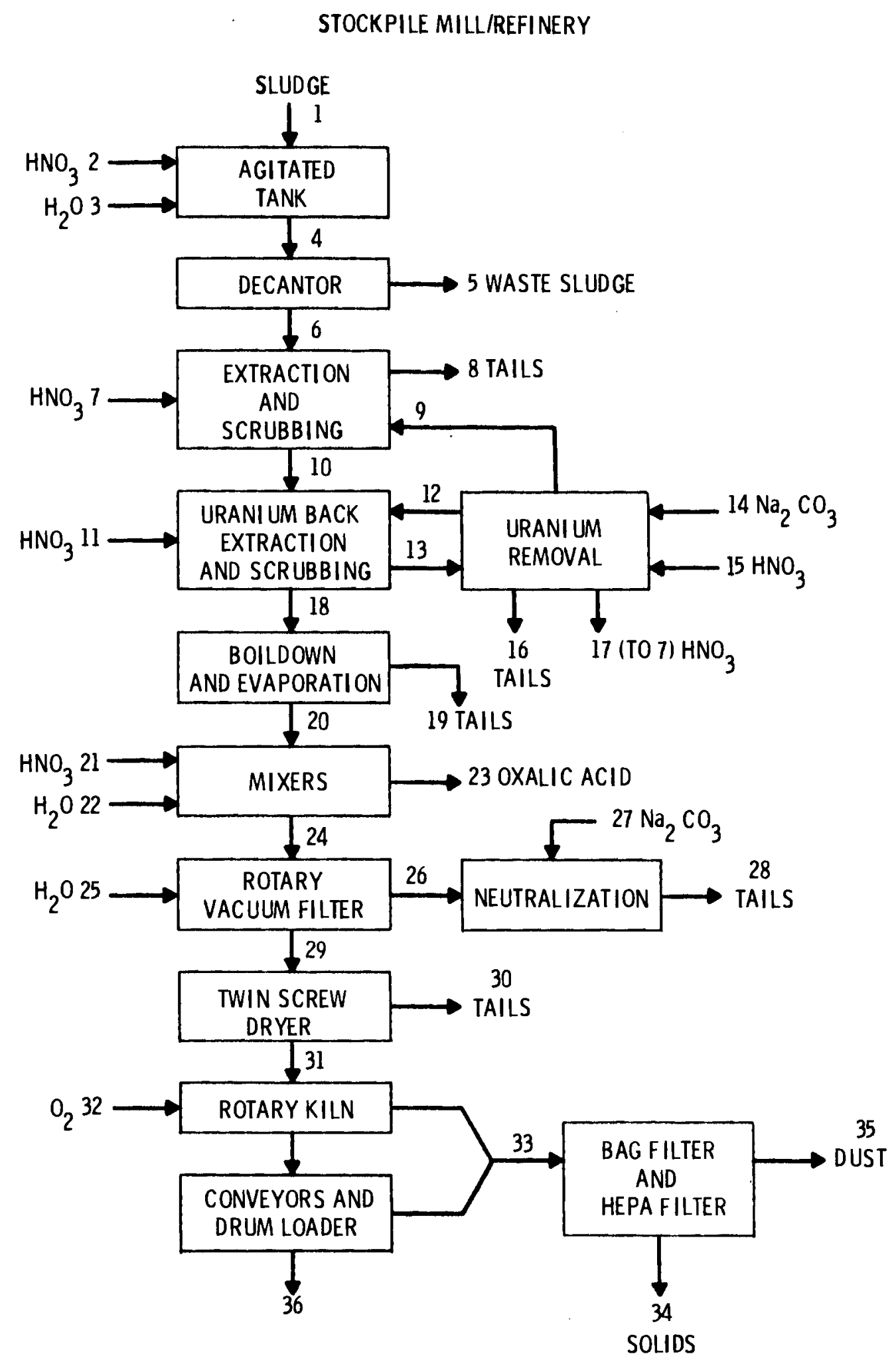

FIGURE 7.1. Stockpile Refining Process 


\section{FLOW STREAMS FOR STOCKPILE REFINERY}

1. $600 \mathrm{lb} / \mathrm{hr}$ sludge $\mathrm{w} /{ }^{232} \mathrm{Th}=132 \mathrm{lb} / \mathrm{hr}$

2. $315 \mathrm{lb} / \mathrm{hr} \mathrm{HNO}_{3}$

3. $517 \mathrm{lb} / \mathrm{hr} \mathrm{H} \mathrm{H}_{2} \mathrm{O}$

4. $1432 \mathrm{lb} / \mathrm{hr} \mathrm{w} /{ }^{232} \mathrm{Th}=132 \mathrm{lb} / \mathrm{hr}$

5. $698 \mathrm{lb} / \mathrm{hr}$ sludge $\mathrm{w} /{ }^{232} \mathrm{Th}=2.64 \mathrm{lb} / \mathrm{hr}$ ( $80 \%$ solids)

6. $734 \mathrm{lb} / \mathrm{hr} w /{ }^{232} \mathrm{Th}=129.36 \mathrm{lb} / \mathrm{hr}$

7. $587 \mathrm{lb} / \mathrm{hr}$ of $4 \mathrm{~N} \mathrm{HNO}_{3}$

8. $1321 \mathrm{lb} / \mathrm{hr} \mathrm{w} /{ }^{232} \mathrm{Th}=.264 \mathrm{lb} / \mathrm{hr}$

9. $2936 \mathrm{lb} / \mathrm{hr}$

10. $2936 \mathrm{lb} / \mathrm{hr} \mathrm{w} /{ }^{232} \mathrm{Th}=129.096 \mathrm{lb} / \mathrm{hr}$

11. $2936 \mathrm{lb} / \mathrm{hr}$ of $.1 \mathrm{~N} \mathrm{HNO}_{3}$

12. $587 \mathrm{lb} / \mathrm{hr}$

13. $3523 \mathrm{lb} / \mathrm{hr}$

14. $1468 \mathrm{lb} / \mathrm{hr}$ of $\mathrm{Na}_{2} \mathrm{CO}_{3}(5 \%)$

15. $734 \mathrm{lb} / \mathrm{hr}$ of $4 \mathrm{~N} \mathrm{HNO}_{3}$

16. $1468 \mathrm{lb} / \mathrm{hr}$

17. $734 \mathrm{lb} / \mathrm{hr}$ of $\mathrm{HNO}_{3}$ to be used to make No. 7 stream

18. $2936 \mathrm{lb} / \mathrm{hr} \mathrm{w} /{ }^{232} \mathrm{Th}=129.096 \mathrm{lb} / \mathrm{hr}$

19. $2324 \mathrm{lb} / \mathrm{hr} \mathrm{H} \mathrm{O}$

20. $612 \mathrm{lb} / \mathrm{hr} \mathrm{w} /{ }^{232} \mathrm{Th}=129.096 \mathrm{lb} / \mathrm{hr}$

21. $34 \mathrm{lb} / \mathrm{hr} \mathrm{HNO}_{3}$

22. $40 \mathrm{lb} / \mathrm{hr} \mathrm{H} \mathrm{H}_{2} \mathrm{O}$

23. $52 \mathrm{lb} / \mathrm{hr}$ oxalic acid

24. $738 \mathrm{lb} / \mathrm{hr} \mathrm{w} /{ }^{232} \mathrm{Th}=129.096 \mathrm{lb} / \mathrm{hr}$

25. $133.4 \mathrm{lb} / \mathrm{hr} \mathrm{H}_{2} \mathrm{O}$

26. $494.4 \mathrm{lb} / \mathrm{hr} \mathrm{w} /{ }^{232} \mathrm{Th}=1.056 \mathrm{lb} / \mathrm{hr}$

27. $143 \mathrm{lb} / \mathrm{hr} \mathrm{Na}{ }_{2} \mathrm{CO}_{3}$

28. $637.4 \mathrm{lb} / \mathrm{hr} \mathrm{w} /{ }^{23} 2 \mathrm{Th}=1.056 \mathrm{lb} / \mathrm{hr}$

29. $377 \mathrm{lb} / \mathrm{hr} \mathrm{w} /{ }^{232} \mathrm{Th}=128.04 \mathrm{lb} / \mathrm{hr}$

30. $109 \mathrm{lb} / \mathrm{hr} \mathrm{H} \mathrm{H}_{2} \mathrm{O}$

31. $268 \mathrm{lb} / \mathrm{hr} \mathrm{w} /{ }^{232} \mathrm{Th}-128.04 \mathrm{lb} / \mathrm{hr}$

32. $20 \mathrm{lb} / \mathrm{hr} \mathrm{O}$

33. $47 \mathrm{lb} / \mathrm{hr} \mathrm{H} \mathrm{H}_{2} \mathrm{O}$ and $95 \mathrm{lb} / \mathrm{hr} \mathrm{CO}_{2} \mathrm{w} /{ }^{232} \mathrm{Th}=2.64 \mathrm{lb} / \mathrm{hr}$

34. $2.614 \mathrm{lb} / \mathrm{hr}^{232} \mathrm{Th}$

35. $47 \mathrm{lb} / \mathrm{hr} \mathrm{H} \mathrm{H}_{2} \mathrm{O}$ and $95 \mathrm{lb} / \mathrm{hr} \mathrm{CO} \mathrm{CO}_{2} /{ }^{232} \mathrm{Th}=.026 \mathrm{lb} / \mathrm{hr}$ 36. $144 \mathrm{lb} / \mathrm{hr} \mathrm{w} /{ }^{232} \mathrm{Th}=125.4 \mathrm{lb} / \mathrm{hr}$

\section{FIGURE 7.1. (cont'd)}




\subsubsection{Feed Preparation}

Sludge is dissolved in acid to obtain a solution containing $200 \mathrm{~g} / \mathrm{l} \mathrm{ThO}_{2}$. Metallic iron is then added and allowed to dissolve slowly to hinder formation of thorium phosphate complexes. When the addition of iron is complete, nitric acid is again introduced to achleve a concentration of $4 \mathrm{M}$ free nitric acid. Large particles of gangue material are filtered off and the feed enters the solvent extraction unit ${ }^{(2)}$.

\subsubsection{Solvent Extraction}

Thorium is extracted from the acid solution using an organic solvent that contains a $50 \%$ solution of tributyl phosphate (TBP) in kerosene. The leach liquor and organic solvent are brought into contact in a 10 stage mixer-settler cascade. The aqueous phase contacts the organic, loses uranium and thorium, and is discharged as raffinate. The loaded solvent is then scrubbed with nitric acid and pumped to the salt stripping process.

\subsubsection{Stripping}

The thorium solution is contacted with a .02 M solution of nitric acid. The thorium is removed, then the freed organic is passed on for recovery of uranium. The thorium-bearing aqueous stream is discharged with a concentration of $50 \mathrm{~g} \mathrm{Th} / \mathrm{e}^{(2)}$.

\subsubsection{Uranium Recovery}

The solvent phase is treated with sodium carbonate to remove the uranium, reacidified, and recycled. The uranium-bearing solution is sent to tails.

\subsubsection{Concentration}

A primary and secondary evaporative system is used to concentrate the thorium nitrate solution. The feed stream enters a secondary evaporative system which consists of three bolldown tanks to concentrate the solution to about $50 \%$ of the original volume. The stream is further concentrated in a

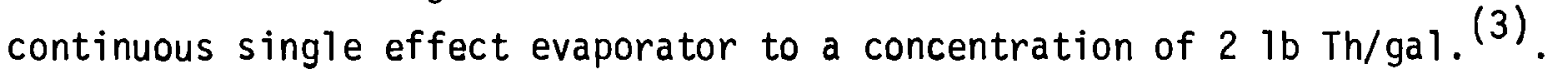




\subsubsection{Precipitation}

The thorium nitrate solution is mixed with nitric acid and heated to $45^{\circ} \mathrm{C}$ with steam. 0xalic acid is added and the solution is agitated for several minutes to facilitate precipitation of thorium oxalate ${ }^{(3)}$.

\subsubsection{Filtration}

The slurry is filtered in a rotary vacuum filter. An oxalate filter cake is discharged containing $30 \%$ to $35 \%$ water by weight. The filtrate is pumped to a plate and frame filter press for further clarification and then neutralized with a solution of sodium carbonate. The spent filtrate combines with the raffinate from the solvent extraction process prior to liquid waste treatment ${ }^{(3)}$.

\subsubsection{Drying}

The oxalate cake is dried in a twin-screw dryer to a $10 \%$ moisture content to avoid spattering in the calciner. The dryer has a jacket temperature of $120^{\circ} \mathrm{C}$ and a screw temperature of $154^{\circ} \mathrm{C}$. The thorium oxalate is discharged into a variable speed auger $(4)$ and has a bulk density of approximately $45 \mathrm{lb} / \mathrm{ft}^{3(3)}$.

\subsubsection{Calcination}

The calcination is carried out in an externally fired rotary kiln for two hours. Gas flowing countercurrently exits at a temperature of $820^{\circ} \mathrm{C}$. The thorium oxide product is a light, finely divided powder $(4)$.

\subsubsection{Packaging}

The thorium oxide is packaged in 55 gallon drums for storage or shipment.

\subsubsection{Effluent Control}

Dust generated during drying and packaging is controlled using a 6000 cfm bag and HEPA filter system. Tailings pond beach dust is controlled using spray equipment to wet down beach material.

Liquid waste consists of discharge from the extraction and filtration steps. These wastes are transported to a clay-lined pond which is sized to allow both storage of tails and evaporation of liquid discharge. A pond 
size of 4 acres was chosen. A 2.5 acre pond is also included for undissolved waste sludge from the feed preparation step. Ultimately, the tails ponds will be covered with soil and vegetated.

\subsection{STOCKPILED THORIUM PRODUCTION COST}

The production costs for developing $\mathrm{ThO}_{2}$ from the stockpiles are estimated at $\$ 5.00 / 1 \mathrm{~b} \mathrm{ThO}_{2}$ for the Chattanooga Sludge, $\$ 3.30 / 1 \mathrm{~b} \mathrm{ThO}_{2}$ for the Curtis Bay sludge, and $\$ 2.30 / 1 \mathrm{~b} \mathrm{ThO} \mathrm{T}_{2}$ for the Fernald sludge.

After taking into account uncertainties in refinery capital and operating costs, thorium recovery efficiency, plant life, and plant capacity using the method described in Section 16, unit costs of $\$ 5.80$ for the Grace sludge, $\$ 4.06$ for the Curtis Bay sludge, and $\$ 2.80$ for the Fernald sludge were calculated. The costs from Table 7.1 are developed in the following sections.

\section{TABLE 7.1. Stockpile Production Costs}

\begin{tabular}{|c|c|c|c|}
\hline Stockpile & $\% \mathrm{ThO}_{2}$ & $\begin{array}{c}\text { Unit Cost* of } \\
\text { Refining } \\
\$ / 1 \mathrm{~b} \mathrm{Th0} \\
\end{array}$ & 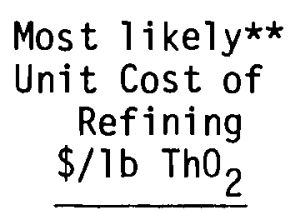 \\
\hline Chattanooga Sludge & $25 \%$ & $\$ 5.00$ & $\$ 5.80$ \\
\hline Curtis Bay -- Miamisburg Sludge & $46 \%$ & $\$ 3.30$ & $\$ 4.00$ \\
\hline Fernald Sludge & $88 \%$ & $\$ 2.30$ & $\$ 2.80$ \\
\hline
\end{tabular}

* Under reference assumptions

$\star \star$ Includes effect of uncertainties

\subsubsection{Refinery Production Costs}

Annual production costs for refining the various sludges are summarized in Tables 7.2, 7.3, and 7.4. A fixed charge rate of 0.2668 is applied to the depreciable capital investment to convert it to an equivalent annualized cost. Similarly, a fixed charge of $10 \%$ is applied to land and working capital. Annual $\mathrm{ThO}_{2}$ production is based on the plant running at rated capacity with the given sludge as input. 
TABLE 7.2. Stockpile Refinery Production Costs:

Chattanooga Sludge $\left(25 \% \mathrm{ThO}_{2}\right)$

Annual Fixed Charges:

Depreciable Capital

Non-Depreciable Capital

Annual Operating Cost

$\$ 814,000$

$\$ 32,000$

Annual Production Cost

$\$ 4,653,000$

$\$ 5,499,000$

Annual $\mathrm{ThO}_{2}$ Production

$1,097,000 \mathrm{lb}$

Unit Cost of Refining

$\$ 5.00 / 1 \mathrm{~b} \mathrm{ThO}_{2}$

TABLE 7.3. Stockpile Refinery Production Costs:

Curtis Bay and Miamisburg $\left(46 \% \mathrm{ThO}_{2}\right)$

Annual Fixed Charges:

Depreciable Capital

Non-Depreciable Capital

Annual Operating Costs

$\$ 814,000$

$\$ 32,000$

Annual Production Cost

$\$ 5,866,000$

$\$ 6,712,000$

Annual $\mathrm{ThO}_{2}$ Production

2,019,000 1b

Unit Cost of Refining

$\$ 3.30 / 1 \mathrm{~b} \mathrm{ThO} 2$

TABLE 7.4. Stockpiles Refinery Production Costs:

Fernald $\left(88 \% \mathrm{ThO}_{2}\right)$

Annual Fixed Charges on Capital Investments

Depreciable Assets

$\$ 814,000$

Non-Depreciable Assets

$\$ 32,000$

Annual Operating Costs

$\$ 7,887,000$

Annual Production Cost

$\$ 8,733,000$

Annual $\mathrm{ThO}_{2}$ Production

$3,869,000 \mathrm{lb}$

Unit Cost of Refining

$\$ 2.30 / 1 \mathrm{~b} \mathrm{ThO} 2$

\subsubsection{Refinery Capital Cost}

The total capital investment for the $600 \mathrm{lb} / \mathrm{hr}$ sludge refinery is estimated to be $\$ 3,370,000$ (Table 7.5 ). The refinery and effluent control building and equipment costs were estimated using the procedure described in Section 6.0. (See Appendix A for Table A-1.1 and Table A-1.2.) 
IABLE 7.5. Stockpiles Refinery Capital Cost

Refinery Buildings and Equipment

$\$ 1,858,000$

Effluent Control Bulldings \& Equipment

122,000

Access Road

100,000

Feasibility Study

100,000

Environmental Impact

100,000

Spare Parts Inventory

53,000

Contingency

322,000

Tailings Pond

238,000

Waste Sludge Landfill

157,000

TOTAL Depreciable Capital Investment

$3,050,000$

Total Land

33,000

Working Capital

287,000

TOTAL CAPITAL INVESTMENT

$3,370,000$

\subsubsection{Refinery Operating Costs}

Estimated refinery operating costs range from $\$ 4,653,000$ to $\$ 7,887,000$ depending on $\mathrm{ThO}_{2}$ content (Table 7.6). Maintenance supplies, plant supplies, utilities, and overheads were estimated using the procedure described in Section 6.0. Utility and reagent expenses are shown in Table 7.7 for various input sludges.

\subsubsection{Transportation}

Transportation charges must be included for shipping sludge to refinery. The haul distance for the Chattanooga sludge $\left(25 \% \mathrm{ThO}_{2}\right)$ is assumed to be 20 miles. One 10 ton haul truck would move about 6 tons/day of this sludge and only one trip a day would be necessary. The capital cost of the truck is estimated to be $\$ 77,000$. The fixed charge rate, assuming a life of 5 years, is approximately 0.3681 (Table 7.8). Operating labor includes costs for a driver and an individual to load and unload the sludge. Labor overhead is assumed to be approximately $35 \%$ of the cost for operating labor. Maintenance is $6 \%$ of the final capital investment. The fuel costs are calculated assuming 60 miles of travel per day at $8 \mathrm{mpg}$ and a gasoline cost of $\$ .75 /$ gallon. 
TABLE 7.6. Stockpiles Refinery Operating Costs

Fixed Operating Costs

Direct Costs

Operating Labor (18 men/shift)

$1,219,672$

Supervision

183,000

Maintenance and Repairs

195,000

Operating Supplies

29,000

Laboratory Charges

183,000

Total Direct Costs

$1,197,000$

Indirect Costs

Plant Overhead

958,000

Administrative Costs

239,000

Total Indirect costs

$1,197,000$

Total Fixed Operating costs

$3,006,672$

Variable Operating Costs

$25 \% \mathrm{ThO}_{2}$

Reagents

$1,192,000$

Utilities

409,000

Transportation

Subtotal

45,000

$1,646,000$

$46 \% \mathrm{ThO}_{2}$

Reagents

$2,074,000$

Utilities

554,000

Transportation

231,000

$2,859,000$

Subtota 7

$3,862,000$

Reagents

787,000

Transportation

231,000

Subtota 1

$4,880,000$

Total Operating Costs

25\% $\mathrm{ThO}_{2}$

$4,653,000$

$46 \% \mathrm{ThO}_{2}$

$5,866,000$

$88 \% \mathrm{ThO}_{2}$

$7,887,000$ 
Transportation charges for Curtis Bay, Miamisburg, and Fernald stockpiles consist of expenses of shipping sludge to the refinery in Tennessee. Thus, a shipping distance of 900 miles round trip shall be assumed with an assumed cost of $\$ 5.00 / 100 \mathrm{wt}$. Total transportation charges for shipping 2,310 tons annually are approximately $\$ 231,000$.

TABLE 7.7. Stockpiled Thorium Reagent and Utilities Cost

\begin{tabular}{|c|c|c|c|c|}
\hline Reagents & Unit Cost & $\begin{array}{l}\text { Annual cost } \\
\left(25 \% \mathrm{ThO}_{2}\right)\end{array}$ & $\begin{array}{l}\text { Annual cost } \\
\left(46 \% \mathrm{ThO}_{2}\right)\end{array}$ & $\begin{array}{l}\text { Annual Cost } \\
\left(88 \% \mathrm{ThO}_{2}\right)\end{array}$ \\
\hline TBP & $\$ 0.88 / 1 b$ & $\$ 102,000$ & $\$ 102,000$ & $\$ 102,000$ \\
\hline Kerosene & $\$ 0.40 / \mathrm{gal}$ & 8,000 & 8,000 & 8,000 \\
\hline Oxalic Acid & $\$ 0.40 / 1 b$ & 468,000 & 936,000 & $1,790,610$ \\
\hline Nitric Acid & $\$ 10.50 / 1001 \mathrm{~b}$ & 578,000 & 966,000 & $1,848,000$ \\
\hline Sodium Carbonate & $\$ 60 / 20001 \mathrm{~b}$ & 30,000 & 56,000 & 107,130 \\
\hline \multirow[t]{2}{*}{ Ammonia } & $\$ 120 / 20001 b$ & 6,000 & 6,000 & 6,000 \\
\hline & & $\$ 1,192,000$ & $\$ 2,074,000$ & $\overline{\$ 3,861,740}$ \\
\hline
\end{tabular}

Utilities

Fuel 0 il

Electricity

Water
$\$ 0.50 / \mathrm{gal}$
$\$ 0.03 / \mathrm{kWh}$
$\$ 0.05 / 1000$ gal

$\$ 108,000$

300,000

1,000

$\$ 409,000$
$\$ 253,000$

300,000

1,500

$\$ 554,500$
$\$ 484,000$ 300,000

2,900

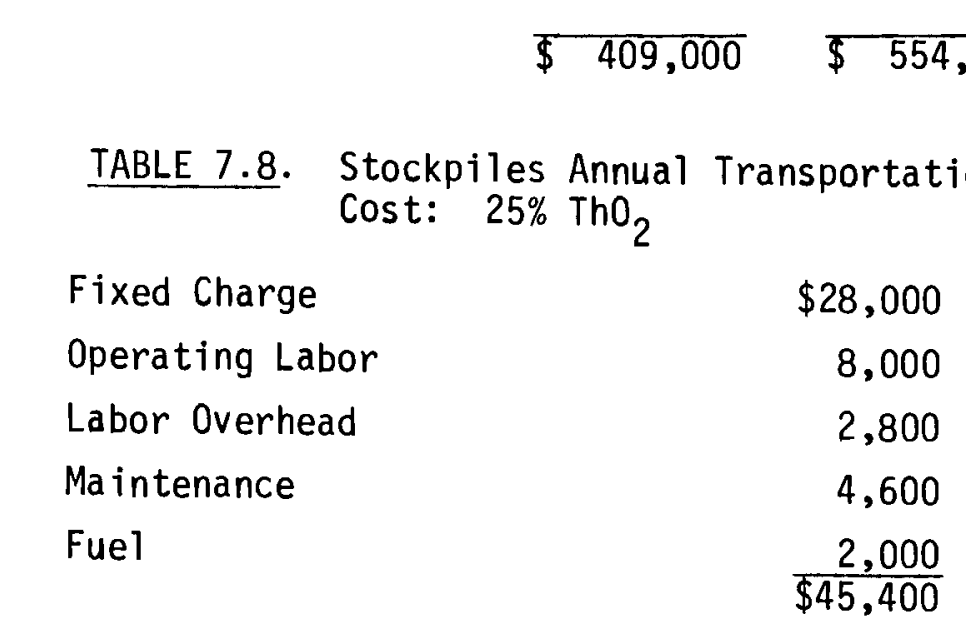




\subsection{MAJOR UNCERTAINTIES}

Major areas of uncertainty affecting the stockpile cost estimates include refinery capital cost, refinery operating cost, thorium recovery efficiency, plant $11 \mathrm{fe}$, and plant capacity. Our estimates for the range of uncertainty in these areas are:

$\begin{array}{ll}\text { refinery capital cost } & +50 \% \text { to }-10 \% \text { of calculated value } \\ \text { refinery operating cost } & +50 \% \text { to }-20 \% \text { of calculated value } \\ \text { thorium recovery efficiency } & 99 \% \text { to } 70 \% \text { with most likely value } \\ & \text { of } 95 \% \\ \text { plant life } & 10 \text { years to } 20 \text { years with most } \\ & \text { likely value of } 10 \text { years } \\ \text { plant capacity } & 600 \mathrm{lb} / \mathrm{hr} \text { to } 100 \mathrm{lb} / \mathrm{hr} \text { with most } \\ & \text { likely value of } 600 \mathrm{lb} / \mathrm{hr}\end{array}$

Table 7.9 shows the impact of these uncertainty ranges on the stockpile unit cost for the three $\mathrm{ThO}_{2}$ concentrations. From the values of the incremental unit costs, a Monte Carlo statistical analys is is performed using the procedure described in Section 16. From this analys is a most likely value and overall cost range is predicted for each sludge concentration. These results are shown below:

\section{Ore Concentration}

$88 \%$

$46 \%$

$25 \%$
Most Likely Value

$\$ 2.80$

$\$ 4.06$

$\$ 5.80$
Range

$\$ 2.02-\$ 4.24$

$\$ 2.86-\$ 5.58$

$\$ 4.30-\$ 8.50$ 


\section{TABLE 7.9. Uncertainty Ranges for Factors Affecting Stockpile Cost Estimates}

\begin{tabular}{|c|c|c|c|c|c|c|}
\hline & \multicolumn{2}{|c|}{$25 \% \mathrm{ThO}_{2}$} & \multicolumn{2}{|c|}{$46 \% \mathrm{ThO}_{2}$} & \multicolumn{2}{|c|}{$88 \% \mathrm{ThO}_{2}$} \\
\hline & $\begin{array}{l}\text { Most Likely } \\
\text { Value }\end{array}$ & Range & $\begin{array}{l}\text { Most Likely } \\
\text { Value } \\
\end{array}$ & Range & $\begin{array}{l}\text { Most Likely } \\
\text { value } \\
\end{array}$ & Range \\
\hline Refinery Capital Cost $\left(\$ / 10^{3} /\right.$ Year $)$ & 846 & 126 to 75.6 & 846 & 126 to 75.6 & 846 & 126 to 75.6 \\
\hline Unit Capital Cost $\left(\$ / 1 \mathrm{~b} \mathrm{ThO}_{2}\right)$ & .77 & 1.16 to .69 & .42 & .63 to .38 & .22 & .33 to .20 \\
\hline Incremental unit cost $\left(\$ / 10^{\mathrm{T}} \mathrm{ThO}_{2}\right)$ & & +.39 to -.08 & & +.21 to -.04 & & +.11 to -.02 \\
\hline Refinery Operating Cost $\$ 10^{3} /$ Year) & 4,653 & 6,980 to 3,722 & 5,866 & 8,799 to 4,693 & 7,887 & 11,831 to 6,304 \\
\hline Unit Operating Cost $\left(\$ / 1 \mathrm{~b} \quad \mathrm{ThO}_{2}\right)$ & 4.24 & 6.39 to 3.39 & 2.91 & 4.36 to 2.32 & 2.04 & 3.06 to 1.63 \\
\hline Incremental Unit cost $\left(\$ / 1 \mathrm{~b} \quad \mathrm{ThO}_{2}\right)$ & & +2.12 to -.85 & & +1.45 to -.59 & & +1.02 to -.41 \\
\hline Thorium Recovery Efficiency (\%) & 95 & 70 to 99 & 95 & 70 to 99 & 95 & 70 to 99 \\
\hline Unit Recovery Efficiency $\left(\$ / 16 \mathrm{ThO}_{2}\right)$ & 5.01 & 6.80 to 4.81 & 3.32 & 4.51 to 3.19 & 2.26 & 3.07 to 2.17 \\
\hline Incremental Unit Cost $\left(\$ / 16 \mathrm{ThO}_{2}\right)$ & & +1.79 to -.20 & & +1.19 to -.13 & & +.81 to -.09 \\
\hline Plant Life (Years) & 10 & 10 to 20 & 10 & 10 to 20 & 10 & 10 to 20 \\
\hline Unit Plant Life Cost $\left(\$ / 16 \mathrm{ThO}_{2}\right)$ & 5.01 & 5.01 to 4.90 & 3.32 & 3.32 to 3.26 & 2.26 & 2.26 to 2.23 \\
\hline Incremental Unit cost $\left(\$ / 1 \mathrm{~b}\right.$ Tho $\left.0_{2}\right)$ & & 0 to -.11 & & 0 to -.06 & & 0 to -.03 \\
\hline Plant Capacity $(1 \mathrm{~b} / \mathrm{hr})$ & 600 & 600 to 100 & 600 & 600 to 100 & 600 & 600 to 100 \\
\hline Unit Plant Capacity Cost $\left(\$ / 16 \mathrm{ThO}_{2}\right)$ & 5.01 & 8.57 to 5.01 & 3.32 & 5.70 to 3.32 & 2.26 & 4.24 to 2.26 \\
\hline Incremental Unit cost $\left(\$ / 1 \mathrm{~b} \mathrm{ThO}_{2}\right)^{2}$ & & +3.56 to 0 & & +2.38 to 0 & & +1.98 to 0 \\
\hline
\end{tabular}




\section{REFERENCES}

1. W. I. Enderlin, An Assessment of U.S. Domestic Capacity for Producing Reactor Grade Thorium Dioxide and Controlling Associated Wastes and Effluents, PNL-2593, Battelle, Pacific Northwest Laboratories, Rich1and, WA 99352,49 pp., 1978.

2. R. J. Callow, The Industrial Chemistry of Lanthanons, Yttrium, Thorium, and Uranium. lst Ed., Pergamon Press, Oxford, London, pp. 113-1119, 1967.

3. Harley A. Wilhelm, The Metal Thorium, proceedings of Conference on Thorium, American Society for Metals, Cleveland, Ohio, pp. 72-75, 1958.

4. F. L. Cuthbert, Thorium Production Technology, Addison-Wesley Publishing, Inc., Massachusetts, p. 151, 1958.

5. "Thorium", Bureau of Mines Minerals Yearbook, U.S. Dept. of Interior, preprint from 1975. 



\subsection{LEMHI PASS DEPOSIT}

\subsection{RESOURCE DESCRIPTION}

The thorium-bearing vein deposits in the Lemhi Pass area have been described in literature by $\operatorname{Stat}(1,2)$. Lying astride the Continental Divide, the Lemhi Pass quadrangle occupies approximately 53 square miles in the eastcentral part of the Beaverhead Mountains of Idaho and Montana. Although the Lemhi Pass thorium district is much larger, the quadrangle contains the most abundant thorium veins. Veins containing copper but no thorium, and barren quartz veins also exist. Staatz ${ }^{(3)}$ estimates the thorium reserves at 67,700 tons $\mathrm{ThO}_{2}$ with an additional 120,000 tons of probable and potential resources. Ten veins within the district contain $94 \%$ of these reserves.

The thorium-bearing veins range from "paper thin" to $30 \mathrm{ft}$ in thickness. Length varies from a few feet to $3,900 \mathrm{ft}$. The largest vein, the Last Chance Vein, spans the $3,900 \mathrm{ft}$ and varies in thickness from $7 \mathrm{ft}$ to $30 \mathrm{ft}$. The veins strike either $N 40^{\circ}-50^{\circ} \mathrm{W}$ or $\mathrm{N} 70^{\circ}-80^{\circ} \mathrm{W}$ and dip steeply $\left(60^{\circ}+\right)$ to the southwest ${ }^{(1)}$.

The thorium content of some of the better explored thorium veins range from $0.001 \%$ to $16.3 \%$ with an average $\mathrm{ThO}_{2}$ content of $0.4 \%$. Grade varies considerably within the veins. Although the overall rare earths content is about equal to the thorium content, the total rare earths oxide content ranges from $.042 \%$ to $10.95 \%$.

Thirty-nine minerals have been identified from various veins, but only seven minerals -- quartz, magnetite, specularite, geothite, thorite, microcline and rutile -- occur in at least two-thirds of the veins. 0ther less common minerals include apatite, muscovite, monazite, red earthy hematite, black maganese oxide minerals, pyrite, and barite. The thorium-bearing veins consist mainly of quartz and quartz-microcline gangue. Veinlets of geothite and hematite cut the thorium veins and contain the thorium-bearing minerals thorite and, to a lesser degree, monazite, and in some cases, brockite and allanite. Of these, thorite is the most abundant mineral.

8.1 


\subsection{MINE DESCRIPTION}

Lemhi Pass is not currently being mined for thorite; thus, the Lemhi Pass thorite mine is a conceptual model based on information about the deposit. The Lemhi Pass mine will utilize underground mining. The methods most likely to be used in producing the thorium vein deposits include: 1) resue stoping, and 2) cut and fill stoping depending on vein dip, vein width, and rock strength.

The referenced thorite mine has an average capacity of 1,000 tpd of ore. It operates 2 shifts/day, 250 days/yr for 28 years. During the first 14 years, approximately 2,734,000 tons of ore are mined containing approximately 14,200 tons of $\mathrm{ThO}_{2}$. Due to inefficiencies in the mining methods, only $70 \%$ or 9,800 tons of $\mathrm{ThO}_{2}$ are recovered. Due to dilution during mining, the average ore grade is reduced to $.28 \%$.

Over the last 14 years of mine life, an additional capital expenditure allows an additional 3,417,000 tons of ore to be accessed. Assuming a mining efficiency of $60 \%$, approximately 13,993 tons of $\mathrm{ThO}_{2}$ are recovered. Mean ore grade varies from $.40 \%$ to $51 \%$ (Table 11 , Appendix D).

Shafts may be required to mine the remainder of the reserves. Due to insufficient data, the cost for recovering the remaining reserves was not determined in this study.

\subsubsection{Mining Process}

The main steps in all underground mining include drilling and blasting the ore, loading and transporting ore to the surface, and establishing ground support. The following sections discuss the major process steps.

\subsubsection{Drilling and Blasting}

Blast holes are wet drilled into the working face using pneumatic drills, loaded with explosives and detonated. Detonation is usually at the end of each shift when miners are out of the work areas.

\subsubsection{Loading and Transporting Rock to Surface}

At the beginning of the following shift, broken rock is removed from the working face. A slusher draws the broken rock into a chute. The rock 
falls down the chute and is loaded by gravity feed into ore cars positioned on the haulage level. When the working face and ore haulage are on the same level, the ore is loaded into the ore cars using a mucking machine. The loaded ore cars are pulled by locomotive to a dump station outside the mine.

\subsubsection{Ground Support}

After removing broken rock from the working area, support is provided, if necessary, by either installing rock bolts, split sets, or, in the case of weak ground, timber sets. Unmined pillars of waste rock or low grade ore are often left to provide support also. Depending on the mining method, waste rock or sand fill may be brought into mined out areas for additional support.

\subsubsection{Loading and Scanning of Rock}

Ore is loaded from the skips into dump trucks on the mine surface. The dump trucks are driven through a scanner to determine ore grade. The trucks are then routed to the mine storage pad. Periodically the ore is loaded from mine storage and transported to the mill.

\subsubsection{Effluent Control}

In working areas with high water inflow, mine water must be pumped from the mining facility. A main pump and several auxiliary pumps transport water from mine excavation points to a 2 acre holding pond on the mine surface.

Airborne effluents consist of fugitive dust, Rn-220 gas, and combustion gases. Dust suppression in working areas of the mine is accomplished by wetting down excavated rock prior to loading. Loaded trucks and ore cars along with haulage rods are similarly wetted down.

A 300,000 cfm mine ventilation system also aids in controlling airborne effluents. Mine ventilation is accomplished by instailing fans and mine openings that provide air passage in and out of working areas. Auxiliary ventilation is provided in deadheaded working areas, especially in regions of high ambient temperature or high thorium concentration. 


\subsection{MILL DESCRIPTION}

Thorite has not been successfully milled on a large scale in the U.S.; therefore, the Lemhi Pass thorite mill is based on a laboratory scale process developed by the U.S. Bureau of Mines ${ }^{(4)}$. The reference mill has a design capacity of 1,000 tpd. The process is assumed to recover $91 \%$ of the thorium and produce a $\mathrm{ThO}_{2}$ product of $99+\%$ purity.

The mill operates $22 \mathrm{hr} /$ day, 250 days/year for 28 years. The mill is located approximately 25 miles from the mine in a flat area suitable for an evaporation pond.

\subsubsection{Milling Process}

The milling process involves acid leaching of thorite followed by solvent extraction and is similar to techniques used in uranium ore processing. The milling process is illustrated in Figure 8.1. The following sections discuss major process steps.

\subsubsection{Run-of-Mine Storage}

Ore arrives at the mill by truck and is stored in piles according to grade. The ore is blended before processing to provide a constant head grade for the mi11. Front end loaders transfer the ore from the storage areas to conveyor. Ore is processed at a rate of 91 tons per hour.

\subsubsection{Crushing and Grinding}

The conveyor discharges the ore into a jaw crusher which is in series with a cone crusher. The minus $1 \mathrm{in}$. discharge from the cone crusher is transferred to the temporary storage bins. From there, the crushed ore is ground to -35 mesh in two $8 \mathrm{ft} \times 8 \mathrm{ft}$ ball mills. After grinding, the ore is mixed with water and transferred to the leaching tanks.

\subsubsection{Leaching}

Slurry from the grinding circuit is fed directly into the first of a series of twelve 3,500 gallon stainless steel tanks equipped with steam heaters to maintain a temperature of $80^{\circ} \mathrm{C}$. The slurry is mixed with sulfuric acid and agitated. The residence time is about $2 \mathrm{hr} .{ }^{(4)}$. The sulfuric acid 


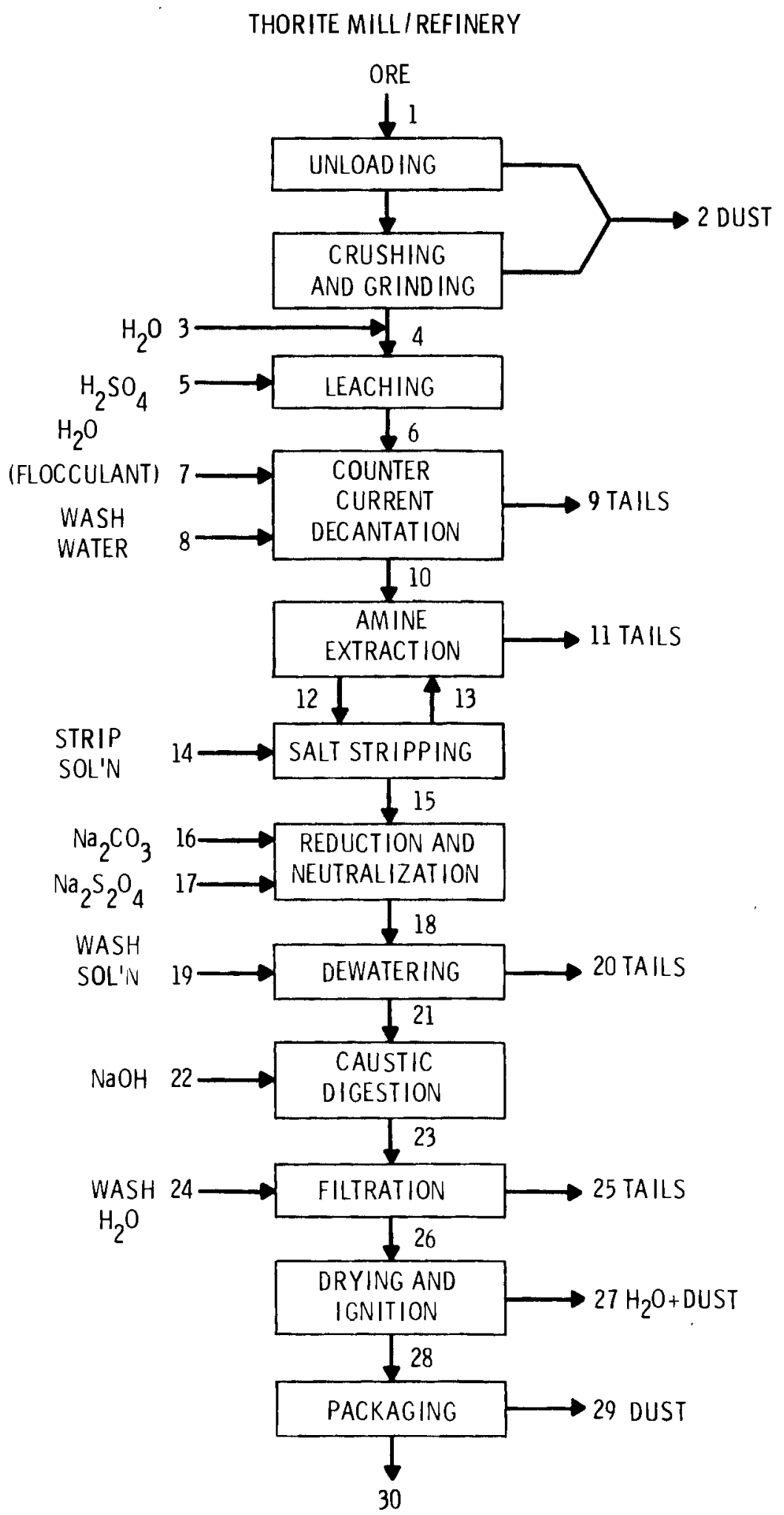

FIGURE 8.1. Lemhi Pass Milling/Refining Process 


\section{FLOW STREAMS FOR LEMHI PASS MILL/REFINERY}

1. 45.5 tons $/ \mathrm{hr}$ ore $\mathrm{w} /{ }^{232} \mathrm{Th}=285.38 \mathrm{lb} / \mathrm{hr}$

2. $4.55 \mathrm{lb} / \mathrm{hr} \mathrm{w} /{ }^{232} \mathrm{Th}=.0132 \mathrm{lb} / \mathrm{hr}$

3. 18.2 tons $/ \mathrm{hr} \mathrm{H}_{2} \mathrm{O}$ or $72.8 \mathrm{gpm}$

4. $63.7 \mathrm{tons} / \mathrm{hr} \mathrm{w} /{ }^{232} \mathrm{Th}=285.37 \mathrm{lb} / \mathrm{hr}$

5. $16,835 \mathrm{lb} / \mathrm{hr} \mathrm{H} \mathrm{H}_{2} \mathrm{SO}_{4}$

6. 72.12 tons $/ \mathrm{hr} w / 232 \mathrm{Th}=285.37 \mathrm{lb} / \mathrm{hr}$

7. 4.55 tons $/ \mathrm{hr}$ of $\mathrm{H}_{2} \mathrm{O}$ (flocculant)

8. 168.35 tons $/ \mathrm{hr}$ of wash $\mathrm{H}_{2} \mathrm{O}$

9. $45 \%$ solids -63.39 tons $/ \mathrm{hr}$ solids $\mathrm{w} /{ }^{232} \mathrm{Th}=20.86 \mathrm{lb} / \mathrm{hr}$ $55 \%$ solution -77.475 tons $/ \mathrm{hr}$ solution $\mathrm{w} /{ }^{232} \mathrm{Th}=2.45 \mathrm{lb} / \mathrm{hr}$

10. 104.155 tons $/ \mathrm{hr} w /{ }^{232} \mathrm{Th}=262.06 \mathrm{lb} / \mathrm{hr}$

11. 104.155 tons $/ \mathrm{hr}{ }^{232} \mathrm{Th}=1.64 \mathrm{lb} / \mathrm{hr}$

12. $19.5 \mathrm{tons} / \mathrm{hr} \mathrm{w} /{ }^{232} \mathrm{Th}=260.42 \mathrm{lb} / \mathrm{hr}$

13. 19.5 tons/hr of stripped organic

14. 12.7 tons $/ \mathrm{hr}$ of strip solution

15. 12.7 tons $/ \mathrm{hr} \mathrm{w} /{ }^{232} \mathrm{Th}=260.42 \mathrm{lb} / \mathrm{hr}$

16. $590.5 \mathrm{lb} / \mathrm{hr} \mathrm{Na}{ }_{2} \mathrm{CO}_{3}$

17. $9.35 \mathrm{Ib} / \mathrm{hr} \mathrm{Na}{ }_{2} \mathrm{~S}_{2} \mathrm{O}_{4}$

18. 13 tons $/ \mathrm{hr} w / 232 \mathrm{Th}=260.42 \mathrm{lb} / \mathrm{hr}$

19. 3.16 tons $/ \mathrm{hr}$ of wash solution $\left(3 \% \mathrm{Na}_{2} \mathrm{SO}_{4}\right)$

20. 12.49 tons $/ \mathrm{hr} w /{ }^{232} \mathrm{Th}=.55 \mathrm{lb} / \mathrm{hr}$

21. 3.67 tons $/ \mathrm{hr} w /{ }^{232} \mathrm{Th}=259.87 \mathrm{lb} / \mathrm{hr}$

22. $95.5 \mathrm{lb} / \mathrm{hr}$ of $\mathrm{NaOH}$

23. 3.72 tons $/ \mathrm{hr} \mathrm{w} /{ }^{232} \mathrm{Th}=259.87 \mathrm{lb} / \mathrm{hr}$

24. 6.25 tons/hr of wash $\mathrm{H}_{2} \mathrm{O}$

25. 6.25 tons $/ \mathrm{hr} \mathrm{w} /{ }^{232} \mathrm{Th}=.0273 \mathrm{lb} / \mathrm{hr}$

26. $.597 \mathrm{ton} / \mathrm{hr} \mathrm{w} /{ }^{232} \mathrm{Th}=259.84 \mathrm{lb} / \mathrm{hr}$

27. $896.2 \mathrm{lb} / \mathrm{hr} \mathrm{s} /{ }^{232} \mathrm{Th}=.105 \mathrm{ib} / \mathrm{hr}$

28. $297.8 \mathrm{lb} / \mathrm{hr} \mathrm{w} /{ }^{232} \mathrm{Th}=295.735 \mathrm{lb} / \mathrm{hr}$

29. $.021 \mathrm{ib} / \mathrm{hr} \mathrm{w} /{ }^{232} \mathrm{Th}=.0185 \mathrm{ib} / \mathrm{hr}$

30. $297.8 \mathrm{lb} / \mathrm{hr} \mathrm{w} /{ }^{232} \mathrm{Th}=259.72$

FIGURE 8.1. (cont'd) 
dissolves the thorium along with impurities in the ore. The sulfuric acid consumption, which is a function of the ore grade and the soluble impurities, can vary from $370 \mathrm{lb} /$ ton to $650 \mathrm{1b} /$ ton of ore.

\subsubsection{Countercurrent Decantation}

The leach liquor contains approximately $60 \%$ solids which must be removed before the solvent extraction. This is accomplished in a five-stage countercurrent decantation process. Flocculant is added to increase the settling rate of the solids. The underflow from the fifth thickener goes to the tailings pond. Based on a two hour settling rate, a settling area of $22 \mathrm{ft}^{2} /$ ton/day is required for the thickener. Final clarification is accomplished using a leaf-type pressure filter with a vacuum of 15 inches of mercury. (4)

\subsubsection{Amine Extraction}

Thorium is extracted from the leach liquor by an organic solvent containing $10 \%$ primary amine, 5\% primary decyl alcohol, and $85 \%$ kerosene. The leach liquor and organic solvent are brought into contact in seven 2,500 gallon mixer/settlers for 15 minutes. The organic losses are estimated to be $1 / 2 \mathrm{gallon} /$ ton processed per hour $(4)$. After the thorium is extracted from the leach liquor, the leach liquor is sent to the tails pond and the thorium containing organic is pumped to the salt stripping process.

\subsubsection{Salt Stripping}

The thorium is stripped from the organic using a premixed salt solution containing $1.5 \mathrm{M} \mathrm{NaCl}$ and $0.5 \mathrm{M} \mathrm{HCl}$. The organic and the salt solution are brought into contact in stainless steel agitated tanks. The salt solution removes the thorium from the organic and the organic is returned to the extraction step. The thorium containing salt solution is pumped to the reduction and neutralization process.

\subsubsection{Reduction and Neutralization}

The salt solution is neutralized with soda ash in agitated tanks to remove the thorium, and sodium hydrosulfide is added to reduce ferric iron (4). The precipitate is dewatered using a disk centrifuge. The filtrate is discarded to the tailings pond. 


\subsubsection{Caustic Digestion}

The dewatered precipitate is pumped to agitated tanks where the precipitate is digested with caustic soda at ambient temperature. A two hour resident time is required and approximately $3 \mathrm{lb}$ of sodium hydroxide are used for each ton of ore ${ }^{(4)}$. The caustic digestion forms thorium hydroxide which is removed from the caustic solution by filtration with a continuous rotary drum filter. The filter has approximately $4 \mathrm{ft}^{2}$ of filter area per ton/hr and yields a precipitate containing $70 \%$ solids. The filtrate is pumped to the tails pond and the cake is discharged to a belt conveyor.

\subsubsection{Drying and Ignition}

The hydroxide cake is dried to a moisture content of $10 \%$ in a twinscrew dryer with a jacket temperature of $120^{\circ} \mathrm{C}$ and a screw temperature of $154^{\circ} \mathrm{C}$. The twin screw dryer is discharged to a rotary kiln where the thorium hydroxide is converted to thorium oxide. The kiln operates at $900^{\circ} \mathrm{C}^{(4)}$. The kiln was sized by assuming that, in normal operation, $7 \%$ of the kiln volume is filled with thorium hydroxide. The rotary kiln discharges $\mathrm{ThO}_{2}$ of $99+\%$ purity, which is packaged in drums for shipment to the fuel fabrication facility.

\subsubsection{Effluent Control}

Two types of effluent are discharged from the mill. Airborne wastes are generated in the crushing, grinding, drying and bagging operation. In addition, liquid and slurry wastes are discharged at various steps in the milling process.

A 26,000 $\mathrm{cfm}$ cyclone dust collection system is used for reducing radioactive dust and silica dust in the unloading, crushing and grinding circuits ${ }^{(5)}$. Dust from drying and ignition steps is controlled in a 21,000 cfm jet impingement scrubber. Packaged dust is sent to a $4000 \mathrm{cfm}$ bag filter system. Beach dust from the tailings pond is controlled by wetting down with portable spray equipment.

Liquid waste consists of discharge from the leaching, countercurrent decantation, amine extraction, dewatering and filtration processes. These 
waste streams are transported to a tails/evaporation pond which is sized to allow both storage of tails and evaporation of liquid discharge. A pond size of 100 acres was chosen based on a net evaporation of 18"/year and recycle of $3 / 4$ of the process water. Ultimately, the talls pond will be covered with soil and vegetated.

\subsubsection{Sulfuric Acid Plant}

In order to reduce the cost of sulfuric acid, an onsite sulfuric acid plant is included with the thorite mill.

\subsection{LEMHI PASS PRODUCTION COST}

The production costs for developing an estimated 23,754 tons of $\mathrm{ThO}_{2}$ from Lemhi Pass are estimated at $\$ 14.60 / 1 \mathrm{~b} \mathrm{ThO}_{2}$ for the first 14 years and $\$ 11.30 / 1 \mathrm{~b}$ $\mathrm{ThO}_{2}$ for the next 14 years. After taking into account uncertainties in mine capital and operating costs, mill capital and operating costs, mill capacity, and mil1 recovery efficiency, a unit cost of $\$ 15.73 / 1 \mathrm{~b}$ for the first stage and $\$ 12.10 / 1 \mathrm{~b}$ for the second stage were found by the method described in Section 16. The costs from Table 8.1 are developed in the following sections.

TABLE 8.1. Lemhi Pass Production Costs

\begin{tabular}{|c|c|c|}
\hline & \multicolumn{2}{|c|}{ Unit Cost $\left(\$ / 1 \mathrm{~b} \quad \mathrm{ThO}_{2}\right)$} \\
\hline & Stage 1 & Stage 2 \\
\hline Mining & $\$ 4.00$ & $\$ 3.86$ \\
\hline Milling & $\$ 10.60$ & $\$ 7.40$ \\
\hline TOTAL from estimates & $\$ 14.60$ & $\$ 11.30$ \\
\hline $\begin{array}{l}\text { TOTAL including uncertainty } \\
\text { (See Section } 8.5 \text { ) }\end{array}$ & $\$ 15.70$ & $\$ 12.10$ \\
\hline
\end{tabular}

\subsubsection{Mine Production Costs}

The production costs for mining the Lemhi Pass resource are shown in Table 8.2. 
TABLE 8.2. Lemhi Pass Mine Production Costs

\begin{tabular}{|c|c|c|}
\hline & Stage 1 & Stage 2 \\
\hline Annualized Capital Cost & $\$ 1,878,000$ & $\$ 981,000$ \\
\hline Annual Operating Costs & $\$ 4,556,000$ & $\$ 7,904,000$ \\
\hline Subtotal & $\$ 6,434,000$ & $\$ 8,885,000$ \\
\hline Depletion Allowance & $\$ 1,415,000$ & $\$ 1,954,000$ \\
\hline Annual Production Cost & $\$ 5,019,000$ & $\$ 6,931,000$ \\
\hline $\begin{array}{l}\text { Annual Levelized Production of } \mathrm{ThO}_{2} \\
\text { Unit Cost of Mining }\end{array}$ & $\frac{1,254,000}{\$ 4.00 / 1 b} 1 b$ & $\frac{1,797,000}{\$ 3.90 / 1 b} 1 b$ \\
\hline
\end{tabular}

Mine capital costs are developed in two stages for the: (1) 9,761 tons of $\mathrm{ThO}_{2}$ and (2) 13,993 tons of $\mathrm{ThO}_{2}$ recovered at Lemhi Pass. The first stage requires a capital expenditure of $\$ 7,611,500$ plus a charge of $\$ 35,200$ for a settling pond to handle mine water and $\$ 45,000$ for miscellaneous equipment to handle uncontrolled dust from storage piles and roads. After a period of 14 years an additional $\$ 4,020,000$ are expended to enable the mine to recover tonnage for another 14 years. A fixed charge rate of 0.2441 is applied to annualize the capital investments for each stage.

Mine operating costs for the first stage are approximately $\$ 4,556,000$ annually. Operating costs for the second stage average \$7,904,000 per year. The depletion allowance is $22 \%$ of the sum of the annualized capital cost and annual operating cost. For a more detailed description of mine design and operation, refer to Appendix D.

\subsubsection{Mil1 Production Costs}

Production costs for milling the Lemhi Pass thorite are summarized in Table 8.3. A fixed charge rate of .2336 is applied to convert the capital investment into an equivalent annual cost.

\subsubsection{Mill Capital Cost}

The total capital investment for a 1,000 ton/day Lemhi Pass thorite mill is estimated to be $\$ 21,701,000$. Itemized capital costs are 1isted in Table 8.4. The mill capital cost and the effluent control equipment capital costs were estimated using the procedure described in Section 6.0. The 
TABLE 8.3. Lemhi Pass Mill Production Cost

$\begin{array}{lcc} & \text { Stage 1 } & \text { Stage 2 } \\ \text { Annual Fixed Charges } & & \\ \text { Depreciable Capital } & \$ 4,663,000 & \$ 4,663,000 \\ \text { Non-Depreciable Capital } & \$ 174,000 & \$ 174,000 \\ \text { Annual Operating Cost } & \frac{\$ 8,453,000}{\$ 13,290,000} & \frac{\$ 8,453,000}{\$ 13,290,000} \\ \text { Annual Production Cost } & \frac{1,254,000}{1 b} & \frac{1,797,000}{1 b} \\ \text { Annual Levelized Production of } \mathrm{ThO}_{2} & \frac{\$ 10.60 / 1 \mathrm{~b}}{\$ 7.40 / 1 \mathrm{~b}} & \end{array}$

TABLE 8.4. Lemhi Pass Mill Capital Cost

Mill Buildings and Equipment Cost

$\$ 9,917,000$

Effluent Control Buildings \& Equipment Cost

$\$ 142,000$

Sulfuric Acid Plant Buildings \& Equipment Cost

$\$ 2,495,000$

Access Road

$\$ 100,000$

Feasibility Study

$\$ 100,000$

Environmental Impact

$\$ 100,000$

Contingency

$\$ 3,700,000$

Tailings Pond (100 acre)

$\$ 3,406,000$

Total Depreciable Capital Investment

$\$ 19,960,000$

Total Land

$\$ 341,000$

Working Capital

$\$ 1,400,000$

Total Capital Inves tment

$\$ 21,701,000$

capital cost of the sulfuric acid plant was estimated from Guthrie ${ }^{(5)}$ based on an acid consumption of 62,500 tons/yr (500 $\mathrm{lb}$ acid/ton of ore). The mill capital cost calculations, effluent control equipment capital cost, and the sulfuric acid plant capital costs are developed in Appendix A (Tables A-2.1, A-2.2, and A-2.3).

\subsubsection{Mill Operating Cost}

The annual operating costs for the Lemhi Pass thorite mill are estimated at $\$ 8,453,000$ (Table 8.5 ). Maintenance supplies, plant supplies, utilities 
and overheads were estimated using the procedure described in Section 6.0. Mill labor costs, reagent expenses, and sulfuric acid plant operating costs will be discussed below.

\section{TABLE 8.5. Lemhi Pass Mill Operating Costs}

Direct Cost

Operating Labor (81 men)

$1,306,000$

Direct Supervisory and Clerical

196,000

Maintenance and Repairs

$1,302,000$

Operating Supplies

195,000

Laboratory Charges

196,000

Reagents

885,000

Utilities

950,000

Sulfuric Acid Plant Operating Cost

$1,320,000$

Indirect Cost

Plant Overhead

$1,682,000$

Administrative Overhead

421,000

TOTAL

$\$ 8,453,000$

\subsubsection{Mill Labor Cost}

Since the solvent extraction process used in the Lemhi Pass thorite mill is similar to that used in existing uranium mills, the operating labor requirements are derived from statistics on uranium ore processing. The operating labor requirements for a 1000 ton/day uranium mill are assumed to be 12.3 tons/man-day or eighty-one men ${ }^{(6)}$.

\subsubsection{Reagents}

Reagent expenses were calculated by estimating the annual theoretical consumption of each reagent and multiplying by the current cost of the reagent. Since a sulfuric acid plant is provided, no expense for sulfuric acid is included. Table 8.6 presents reagent consumption, unit cost and annual cost. The total reagent expense is $\$ 885,000$. 
TABLE 8,6. Lemhi Pass Reagent Cost

\begin{tabular}{|c|c|c|c|}
\hline Reagent & Annual Consumption & Unit $\operatorname{Cos} t^{(a)}$ & Annual Cost \\
\hline $\mathrm{NaCl}$ & 9,000 tons & $\$ 41 /$ ton & $\$ 369,000$ \\
\hline Kerosene & $88,0001 \mathrm{~b}$ & $0.4 / g a 1$ & 5,000 \\
\hline $\mathrm{HCl}$ & 1,875 tons & $61.3 /$ ton & 115,000 \\
\hline $\mathrm{NaCO}_{3}$ & 2,500 tons & $68.9 /$ ton & 172,000 \\
\hline $\mathrm{Na}_{2} \mathrm{SO}_{2} \mathrm{O}_{4}$ & $7,7001 b$ & $0.58 / 1 b$ & 4,000 \\
\hline $\mathrm{NaOH}$ & $753,5001 b$ & $0.24 / 1 b$ & 181,000 \\
\hline $\mathrm{NaSO}_{4}$ & 751 tons & $51.9 /$ ton & 739,000 \\
\hline \multicolumn{3}{|c|}{ TOTAL Reagent Expense } & $\$ 885,000$ \\
\hline
\end{tabular}

(a) From Chemical Marketing Report, January 23, 1978.

\subsubsection{Sulfuric Acid Plant Operating Expense}

The operating expense for the sulfuric acid plant (raw materials, operating supplies, maintenance materials, labor, supervision, utilities and indirect cost) were estimated from Guthrie ${ }^{(5)}$. For a 62,500 tpy sulfuric acid plant escalated to January 1978, the operating cost was estimated to be $\$ 1,320,000 / \mathrm{yr}$.

\subsection{MAJOR UNCERTAINTIES}

Major areas of uncertainty affecting the $\mathrm{ThO}_{2}$ unit cost estimate inciude mine capital and operating costs, mill capital and operating costs, mill capacity, and mill recovery efficiency. Our estimates for the range of uncertainty in these areas are:

Mine Capital Cost

Mine Operating Cost

Mill Capital Cost

Mi11 Operating Cost

Mil1 Capacity

Mi11 Recovery Efficiency
$+50 \%$ to $-10 \%$ of calculated value

$+50 \%$ to $-10 \%$ of calculated value

$+50 \%$ to $-10 \%$ of calculated value

$+50 \%$ to $-10 \%$ of calculated value

2000 tpd to 500 tpd with most likely value of 1000 tpd

$86 \%$ to $48 \%$ with most likely value of $64 \%$ 
Table 8.7 shows the impact of these uncertainty ranges on the unit cost of $\mathrm{ThO}_{2}$ for the two stages. From the incremental unit cost values, a Monte Carlo statistical analysis is performed using the procedure described in Section 16. A most 11kely value and overall cost range is predicted for each stage from this analysis and is shown below:

Stage

1

2

\section{Most Likely Value $\left(\$ / 1 \mathrm{~b} \mathrm{ThO}_{2}\right)$}

15.73

12.10
Range $\left(\$ / 1 \mathrm{~b} \mathrm{ThO}_{2}\right)$

$\$ 10.80$ to $\$ 22.90$

$\$ 8.91$ to $\$ 17.40$ 
TABLE 8.7. Uncertainty Ranges for Factors Affecting $\mathrm{ThO}_{2}$ Unit Cost for Lemhi Pass

\begin{tabular}{|c|c|c|c|c|}
\hline & & Stage 1 & & Stage 2 \\
\hline & $\begin{array}{c}\text { Most Likely } \\
\text { Value } \\
\end{array}$ & Range & $\begin{array}{c}\text { Most Likely } \\
\text { Value } \\
\end{array}$ & Range \\
\hline $\begin{array}{l}\text { Mine Capital Cost } \\
\text { Unit Mill Capital Cost } \\
\text { Incremental Unit Cost }\end{array}$ & $\begin{array}{c}\$ 1,878,000 \\
\$ 1.17\end{array}$ & $\begin{array}{l}\$ 2,817,000 \text { to } \$ 1,690,000 \\
\$ 1.75 \text { to } \$ 1.05 \\
+.58 \text { to }-.12\end{array}$ & $\begin{array}{l}\$ \quad 931,000 \\
\$ .73\end{array}$ & $\begin{array}{c}\$ 1,472,000 \text { to } \$ 883,000 \\
\$ .64 \text { to } \$ .38 \\
+.21 \text { to }-.05\end{array}$ \\
\hline $\begin{array}{l}\text { Mine Operating Cost } \\
\text { Unit Mill Operating Cost } \\
\text { Incremental Unit Cost }\end{array}$ & $\begin{array}{c}\$ 4,556,000 \\
\$ 2.83\end{array}$ & $\begin{array}{c}\$ 6,834,001) \text { to } \$ 4,100,000 \\
\$ 4.25 \text { to } \$ 2.55 \\
+\$ 1.42 \text { to }-\$ .28\end{array}$ & $\begin{array}{l}\$ 7,904,000 \\
\$ 3.43\end{array}$ & $\begin{array}{l}\$ 11,856,000 \text { to } \$ 7,114,000 \\
\$ 5.15 \text { to } \$ 3.09 \\
+\$ 1.72 \text { to }-\$ .34\end{array}$ \\
\hline $\begin{array}{l}\text { Mill Capital Cost } \\
\text { Unit Mill Capital Cost } \\
\text { Incremental Unit Cost }\end{array}$ & $\begin{array}{c}\$ 4,837,000 \\
\$ 3.86\end{array}$ & $\begin{array}{c}\$ 7,256,000 \text { to } \$ 4,353,000 \\
\$ 5.79 \text { to } \$ 3.47 \\
+\$ 1.53 \text { to }-\$ .39\end{array}$ & $\begin{array}{l}\$ 4,837,000 \\
\$ 2.69\end{array}$ & $\begin{array}{c}\$ 7,256,000 \text { to } \$ 4,353,000 \\
\$ 4.04 \text { to } \$ 2.42 \\
+\$ 1.35 \text { to }-\$ .27\end{array}$ \\
\hline $\begin{array}{l}\text { Mill Operating Cost } \\
\text { Unit Mill Operating Cost } \\
\text { Incremental Unit Cost }\end{array}$ & $\begin{array}{c}\$ 8,453,000 \\
\$ 6.74\end{array}$ & $\begin{array}{l}\$ 12,680,000 \text { to } \$ 7,608,000 \\
\$ 10.11 \text { to } \$ 6,07 \\
+3.37 \text { to }-\$ .67\end{array}$ & $\begin{array}{l}\$ 8,453,000 \\
\$ 4.70\end{array}$ & $\begin{array}{c}\$ 12,680,000 \text { to } \$ 7,608,000 \\
\$ 7.06 \text { to } \$ 4.23 \\
+\$ 2.36 \text { to }-\$ .47\end{array}$ \\
\hline $\begin{array}{l}\text { Plant Capacity } \\
\text { Unit Plant Capacity Cost } \\
\text { Incremental Unit Cost }\end{array}$ & $\begin{array}{c}1000 \text { tpd } \\
\$ 14.60\end{array}$ & $\begin{array}{c}500-2,000 \text { tpd } \\
\$ 18.02 \text { to } \$ 11.92 \\
+\$ 3.42 \text { to }-\$ 2.68\end{array}$ & $\begin{array}{l}1000 \mathrm{tpd} \\
\$ 11.26\end{array}$ & $\begin{array}{l}500-2,000 \text { tpd } \\
\$ 13.89 \text { to } \$ 9.21 \\
+\$ 2.63 \text { to }-\$ 2.05\end{array}$ \\
\hline $\begin{array}{l}\text { Ore Recovery } \\
\text { Unit Ore Recovery Cost } \\
\text { Incremental Unit Cost }\end{array}$ & $\begin{array}{c}64 \% \\
\$ 14.60\end{array}$ & $\begin{aligned} 86 \% & \text { to } 48 \% \\
\$ 19.47 & \text { to } \$ 10.87 \\
+\$ 4.87 & \text { to }-\$ 3.73\end{aligned}$ & $\begin{array}{r}64 \% \\
\$ 11.26\end{array}$ & $\begin{aligned} & 48 \% \text { to } 86 \% \\
& \$ 15.01 \text { to } \$ 8.38 \\
&+\$ 3.75 \text { to }-\$ 2.88\end{aligned}$ \\
\hline
\end{tabular}




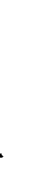




\section{REFERENCES}

1. M. H. Staatz, Geology and Description of the Thorium-Bearing Veins, Lemhi Pass Quadrangle, Idaho and Montana. USGS Bulletin 1351, 94 pp., 1972.

2. M. H. Staatz, "Thorium Veins in the United States". Economic Geology, 69:494-507, 1974 .

3. M. H. Staatz, Proceedings of the Uranium Industry Seminar, 1978, GJ0$108(78)$, U.S. Dept. of Energy, Grand Junction, Colorado, pp. 109-115, 1978.

4. S. R. Borrowman and J. B. Rosenbaum, Recovery of Thorium From Ores in Colorado, Idaho, and Montana, USBM 5916, United States Bureau of Mines, Update, 16 pp. 1976.

5. K. M. Guthrie, Process Plant Estimating Evaluation and Control, Craftman Book Company of America, pp. 80-97, 1974.

6. R. C. Merritt, The Extraction Metallurgy of Uranium, Colorado School of Mines Research Institute, p. 377, 1971. 


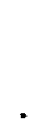




\subsection{THORIUM PRODUCTION FROM HALL MOUNTAIN, IDAHO}

\subsection{RESOURCE DESCRIPTION}

Hall Mountain is located approximately 3 miles east of the U.S. border Station at Porthi11, Idaho (1). Thorium veins exist in the quartz diorite of the Purcell sills and in the belt subgroup of the Prichard Formation. The thorium-bearing mineralization, mainly thorite, is erratic and commonly occurs along fractures.

Thorium has been identified in 11 narrow, steeply dipping veins in a halfsquare mile area of the deposit. The veins strike from $N 42^{\circ} \mathrm{W}$ to $N 30^{\circ} \mathrm{E}$ and dip into the hill from $35^{\circ}$ to over $60^{\circ}$ from the horizontal. The thickness of the veins range from less than $1 \mathrm{ft}$ to $13 \mathrm{ft}$ with an average width of $4 \mathrm{ft}$. The exposed length of the veins range from $6 \mathrm{ft}$ to $700 \mathrm{ft}$ with an average length of $185 \mathrm{ft}$. The poorly exposed veins out crop between $2400 \mathrm{ft}$ and $4000 \mathrm{ft}$ above sea level and are covered with lake deposits and glacial till below $2400 \mathrm{ft}$.

Mineralization of the Hall Mountain area has not been quantified. However, minerals associated with thorite include quartz, calcite, chlorite, altite, and sphene. Based on geological and sample data published by Staatz ${ }^{(2)}$, the mineable ore reserve is estimated at 5210 tons of $\mathrm{ThO}_{2}$ with an average ore grade of $1.3 \%$. The probable potential resource in this district is 29,900 tons. This area contains $3.7 \%$ of the total resource for identified vein deposits in the U.S.

\subsection{MINE DESCRIPTION}

Currently, Hall Mountain is not being mined for thorium. The conceptual Hall Mountain mine is thus based on the Lemhi Pass mine assuming a similar geology. The conceptual mine produces approximately 400 tpd with a mine life of $5 \mathrm{yr}$. The mine is designed to operate two shifts/day, 250 days/yr. A dilution rate of $15 \%$ is assumed for this study. Thus, the average run of mine grade is assumed to be $1.1 \%$. 


\subsubsection{Mining Process}

The process for mining Hall Mountain thorite is essentially the same as for mining Lemhi Pass thorite. The mining process is described in Section 8.2.1 of this report.

\subsection{MILL DESCRIPTION}

The reference thorite mill utilizes acid leaching of ore followed by solvent extraction. The reference thorite mill has a capacity of 400 tpd of ore which matches the output from the Hall Mountain thorite mine. The mill is assumed to operate $5 \mathrm{yr}$. Since the average thorium content of the ore is estimated to be $1.1 \%$, the mill would produce about $8090 \mathrm{lb} /$ day of $\mathrm{ThO}_{2}$.

\subsubsection{Milling Process}

The process for milling Hall Mountain thorite is assumed to be the same as for milling Lemhi Pass thorite. The process is described in Section 8.3.1 of this report.

\subsection{HALL MOUNTAIN PRODUCTION COSTS}

The production costs for developing an estimated 5210 tons $/ \mathrm{ThO}_{2}$ from Hall Mountain is $\$ 6.00 / 1 \mathrm{~b} \mathrm{ThO} \mathrm{C}_{2}$ (Table 9.1). After analyzing the uncertainty in mine capital and operating costs, mill capital and operating costs, plant capacity, and mill recovery efficiency, a unit cost of $\$ 6.30 / 1 \mathrm{~b} \mathrm{Th0_{2 }}$ was found by the method described in Section 16. Costs from Table 9.1 are developed in the following sections.

TABLE 9.1. Hall Mountain Production Costs

$$
\begin{gathered}
\text { Unit Cost } \\
\left(\$ / 1 \mathrm{~b} / \mathrm{ThO}_{2}\right)
\end{gathered}
$$

Mining

Milling

Total from Estimates

Total Including Uncertainty
$\$ 1.41$

$\$ 4.61$

$\$ 6.00$

$\$ 6.30$ 


\subsubsection{Mine Production Costs}

The mine production costs for operating the Hall Mountain mine are shown in Table 9.2. A fixed charge rate of 0.3681 is applied to the capital investment. Capital and operating costs for the mine are developed in the following sections.

TABLE 9.2. Ha11 Mountain Mine Production Costs

Annualized Capital Cost

Annual Operating Costs

Subtotal

Depletion Al lowance

Annual Production Costs

Average Annual Production of $\mathrm{ThO}_{2}$

Unit cost of Mining
$\$ 1,434,000$

$2,217,000$

$\$ 3,651,000$

803,000

$\$ 2,848,000$

$\underline{2,023,000} 1 \mathrm{bs}$

$\$ 1.40 / 1 \mathrm{~b}$

\subsubsection{Mine Capital Costs}

Capital costs are calculated from the Lemhi Pass cost estimate using a 0.75 scaling factor $(4)$. The estimated capital cost is calculated to be $\$ 3,829,000$. A settling pond to handle mine water costs an additional $\$ 21,700$. Miscellaneous equipment to handle uncontrolled dust from storage piles and roads costs approximately $\$ 45,000$. Total capital cost, including effluent control, is $\$ 3,895,000$.

\subsubsection{Mine Operating Costs}

The mine operating cost is estimated using the unit cost calculated from the first 7 years of operating the Lemhi Pass mine (Table 5, Appendix D). This value is $\$ 22.17 /$ ton of ore and includes expenses for exploration and development. Assuming a production rate of $400 \mathrm{tpd}$ for 250 days/yr, the annua 1 operating cost for Hall Mountain is $\$ 2,217,000$.

\subsubsection{Mi11 Production Costs}

The production cost for militing Hail Mountain ore is $\$ 4.60 / 1 \mathrm{~b} \mathrm{ThO}_{2}$ (Table 9.3). A fixed charge rate of 0.3681 is applied to the capital investment. Mi11 Capital and operating costs are discussed in the following sections. 
TABLE 9.3. Hall Mountain Mill Production Costs

Annual Fixed Charges:

Depreciable Capital

$\$ 3,869,000$

Non-Depreciable Capital

92,000

Annual Operating Cost

$\$ 5,363,000$

Production Cost $\$ 9,324,000$

Annual $\mathrm{ThO}_{2}$ Production

$\$ 2,023,000$

Unit cost of Milling

$\$ 4.60 / 1 \mathrm{~b} \mathrm{ThO} 2$

\subsubsection{Mill Capital Costs}

The total capital investment for a 400 tpd thorite mill is estimated at $\$ 11,426,000$. The capital cost is scaled down from the Lemhi Pass mill capital cost by multiplying by the capacity ratio to the 0.7 power ${ }^{(3)}$. The costs are summarized in Table 9.4.

TABLE 9.4. Hall Mountain Mill Capital Cost

400 Tons Per Day

Total Depreciable Capital Investment

$\$ 10,510,000$

Land

179,000

Working Capital

737,000

TOTAL Capital Investment

$\$ 11,426,000$

\subsubsection{Mill Operating Costs}

The components of annual operating cost are shown in Table 9.5. Costs for electric power and fuel oll are scaled down using the 0.7 scaling factor $(3)$ because they depend on equipment size and would be influenced by economies of scale. Total labor force is estimated from typical manpower requirements of a uranium mill of similar size ${ }^{(5)}$. Operating labor rates are estimated at $\$ 8.06 / \mathrm{hr}$. Reagents and water consumption are scaled down linearly. 
TABLE 9.5. Hall Mountain Mill Operating Cost

Direct Costs

$\begin{array}{lr}\text { Operating Labor (62 men) } & 999,000 \\ \text { Supervisory and Clerical } & 150,000 \\ \text { Maintenance and Repairs } & 685,000 \\ \text { Operating Supplies } & 103,000 \\ \text { Laboratory Charges } & 150,000 \\ \text { Reagents } & 354,000 \\ \text { Utilities } & \\ \quad \text { Fuel 0il } & 301,000 \\ \quad \text { Electricity } & 217,000 \\ \quad \text { Water } & 29,000 \\ \text { Sulfuric Acid Operating Cost } & 1,000,000\end{array}$

Indirect Costs

Plant Overhead

$1,100,000$

Administrative Costs

275,000

TOTAL Operating Costs

$\$ 5,363,000$

\subsection{MAJOR UNCERTAINTIES}

Major areas of uncertainty affecting the $\mathrm{ThO}_{2}$ unit cost estimates include mine capital and operating costs, mill capital and operating costs, plant capacity, and mill recovery efficiency. Our estimates for the range of uncertainty in these areas are:

Mine Capital Cost

Mine Operating Cost

Mill Capital Cost

Mill Operating Cost

Plant Capacity

Mill Recovery Efficiency

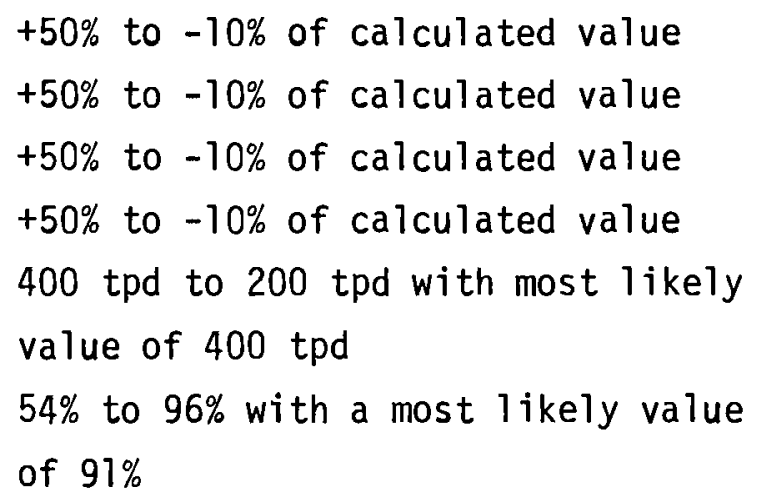
of $91 \%$ 
The impact of these uncertainty ranges on the unit cost of $\mathrm{ThO}_{2}$ is shown in Table 9.6. From the incremental unit cost values, a Monte Carlo statistical analysis is performed using the procedure described in Section 16. From this analysis a most 11 kely value of $\$ 6.30 / 1 \mathrm{~b} \mathrm{ThO}_{2}$ and overall cost range of $\$ 5.60 / 1 \mathrm{~b}$ to $\$ 9.30 / 1 \mathrm{~b}$ is predicted for the unit cost of $\mathrm{ThO}_{2}$.

TABLE 9.6. Uncertainty Ranges for Factors Affecting $\mathrm{ThO}_{2}$ Unit Cost for Hall Mountain

\begin{tabular}{|c|c|c|}
\hline & $\begin{array}{l}\text { Most Likely } \\
\text { Value } \\
\end{array}$ & Range \\
\hline Mine Capital Cost $\$ 10^{3} / y r$ & $1,119^{(a)}$ & 1,678 to 1,007 \\
\hline Unit Mine Capital Cost $\$ / 1 \mathrm{~b} \mathrm{ThO}_{2}$ & .55 & .83 to .50 \\
\hline Incremental Unit Cost $\$ / 1 \mathrm{~b} \mathrm{ThO} \mathrm{T}_{2}$ & & +.28 to -.05 \\
\hline Mine Operating Cost $\$ 10^{3}$ & $1,729^{(a)}$ & 2,594 to 1,556 \\
\hline Unit Mine Operating Cost $\$ / 1 \mathrm{~b} \mathrm{ThO}_{2}$ & .85 & 1.28 to .77 \\
\hline Incremental Unit Cost $\$ / 1 \mathrm{~b} \mathrm{ThO}_{2}$ & & +.43 to -.08 \\
\hline Mill Capital Cost $\$ 10^{3}$ & 3,961 & 5,942 to 3,565 \\
\hline Unit Mill Capital Cost $\$ / 1 \mathrm{~b} \mathrm{ThO}_{2}$ & 1.96 & 2.94 to 1.76 \\
\hline Incremental Unit cost $\$ / 1 \mathrm{~b} \mathrm{ThO}_{2}$ & & +.98 to -.20 \\
\hline Mi11 Operating Cost $\$ 10^{3}$ & 5,363 & 8,045 to 4,827 \\
\hline Unit Mill Operating Cost $\$ / 1 \mathrm{~b} \mathrm{ThO}_{2}$ & 2.65 & 3.98 to 2.39 \\
\hline Incremental Unit Cost $\$ / 1 \mathrm{~b} \mathrm{ThO}_{2}$ & & +1.33 to -.26 \\
\hline Plant Capacity tpd & 400 & 400 to 200 \\
\hline Unit Plant Capacity Cost $\$ / 1 \mathrm{~b} \mathrm{ThO}_{2}$ & & 5.40 to 6.53 \\
\hline Incremental Unit Cost $\$ / 1 \mathrm{~b} \mathrm{ThO}_{2}$ & & +1.13 to 0 \\
\hline Thorium Recovery Efficiency \% & 91 & $54 \%$ to $96 \%$ \\
\hline Unit Recovery Efficiency Cost $\$ / 1 \mathrm{~b} \mathrm{ThO}_{2}$ & 6.02 & 10.14 to 5.71 \\
\hline Incremental Unit Cost $\$ / 1 \mathrm{~b} \mathrm{ThO}_{2}$ & & +4.12 to -.31 \\
\hline
\end{tabular}

(a) Depletion allowance (22\%) is subtracted from cost.

(b) Mill recovery efficiency only. No data is available to predict mine efficiency. 


\section{REFERENCES}

1. M. H. Staatz, Thorium Rich Veins of Hall Mounta in in Northernmost Idaho, Economic Geology, Vol. 67, 1972, pp. 240-248.

2. M. H. Staatz, Proceedings of the Uranium Industry Seminar, 1978, GJ0108 (78), U.S. Dept. of Energy, Grand Junction, Colorado, pp. 109-115, 1978.

3. Robert H. Perry, Chemical Engineers Handbook, 5th Ed., McGraw-Hi11, Inc., New York, pp. 25-16 and 25-17, 1973.

4. Chemical and Operating Cost Estimating System Handbook, Prepared for the United States Dept. of Interior, Bureau of Mines, by STRAAM Engineers, Inc., Arcadia, CA, 374 pp., Ju7y 1978.

5. R. C. Merritt, The Extractive Metallurgy of Uranium, Colorado School of Mines Research Institute, Golden, $\mathrm{CO}, \mathrm{p} .377,1971$. 


\subsection{THORIUM PRODUCTION FROM WET MOUNTAIN}

\subsection{RESOURCE DESCRIPTION}

Thorium has been identified in over 400 narrow, steeply dipping veins in a 22 square mile tract of precambrian rocks on the flank of the Wet Mountain in Colorado $(1,2,3)$.

These veins range in thickness from less than $1 \mathrm{ft}$ to $50 \mathrm{ft}$ with an average thickness of about $5 \mathrm{ft}$ and dip in excess of $60^{\circ}$ from horizontal. The topography is rugged, ranging from $7,900 \mathrm{ft}$ to $9,500 \mathrm{ft}$ above sea level, and the veins are poorly exposed with the exposed length ranging from $1 \mathrm{ft}$ to $5,000 \mathrm{ft}$.

The thorium-bearing mineralization has been described as a "thorite like mineral" ${ }^{4}$, and is presumed to be thorite. The economic thorium vein minerals occur as irregularly distributed constituents of veins, as disseminations, and as small local concentrations in border areas of shattered rock. The $\mathrm{ThO}_{2}$ content of these vein deposits ranges from $0.02 \%$ to $12.5 \%$ with the average ore grade of $1.1 \%$.

Staatz has estimated the size of these reserves at 66,900 tons of $\mathrm{ThO}_{2}$. Total probable potential resource in this district is 158,000 tons, or $46.9 \%$ of the total reserve for identified vein deposits in the U.S. (4)

\subsection{MINE DESCRIPTION}

Currently, Wet Mountain is not being mined for $\mathrm{ThO}_{2}$. Thus, the Wet Mountain mine is modeled after the Lemhi Pass mine. Because of the scattered nature of the deposits, several small mines will be utilized to recover the tonnage rather than one large mine. The conceptual mine produces 350 tpd of ore and operates for 5 years. The mine runs 2 shifts/day for 250 days/yr. A dilution rate of $15 \%$ is assumed and thus the run of mine grade is reduced to $.96 \%$.

\subsubsection{Mining Process}

The mining process is essentially the same as for Lemhi Pass thorite. This process is described in Section 8.2.1 of this report. 


\subsection{MILL DESCRIPTION}

The reference thorite mill utilizes acid leaching of ore followed by solvent extraction. The mill has a capacity of 350 tpd of ore and operates for a life of $5 \mathrm{yr}$ at 3 shifts/day for 250 days/yr. The mill is assumed to process ore with an average grade of $0.96 \%$ and produces $99+\% \mathrm{ThO}_{2}$ with $91 \%$ recovery, or approximately 6,120 tpd of reactor grade $\mathrm{Th}_{2}$.

\subsubsection{Milling Process}

The process for milling Wet Mountain thorite is essentially the same as the process for milling Lemhi Pass thorite. This process is described in Section 8.3.1 of this report.

\subsection{WET MOUNTAIN PRODUCTION COSTS}

The production costs for developing an estimated 66,900 tons $\mathrm{ThO}_{2}$ from Wet Mountain is $\$ 7.30 / 1 \mathrm{~b} \mathrm{ThO} \mathrm{T}_{2}$ (Table 10.1). After analyzing the uncertainty in mine capital and operating costs, mill capital and operating costs, mine capacity, mill capacity, and mill recovery efficiency. a unit cost of $\$ 8.30 / 1 \mathrm{~b}$ $\mathrm{ThO}_{2}$ was found by the method described in Section 16. Costs from Table 10.1 are developed in the following sections.

\section{TABLE 10.1 Wet Mountain Production Costs}

$\begin{array}{lc} & \begin{array}{l}\text { Unit Cost } \\ \$ / 1 \mathrm{~b} \mathrm{Th0} \mathrm{T}_{2}\end{array} \\ \text { Mining } & \$ 1.83 \\ \text { Milling } & \$ 5.48 \\ \text { TOTAL from estimates } & \$ 7.30 \\ \text { TOTAL (including uncertainty) } & \$ 8.30\end{array}$

\subsubsection{Mine Production Costs}

The mine production costs for Wet Mountain are shown in Table 10.2. The unit cost of mining $\mathrm{ThO}_{2}$ is $\$ 1.80 / 1 \mathrm{~b} \mathrm{ThO} \mathrm{C}_{2}$. A fixed charge rate of 0.3681 is applied to the capital investment to annualize it over five years. Capital and operating costs are developed in the following sections. 
TABLE 10.2. Wet Mountain Mine Production Costs

Annualized Capital Cost

$\$ 1,643,000$

Annual Operating Costs

$1,940,000$

Subtotal

$\$ 3,583,000$

Depletion Al lowance

$\frac{788,000}{\$ 2,795,000}$

Annual Production Cost

$1,528,800 \mathrm{lb}$

Annual Production of $\mathrm{ThO}_{2}$

$\$ 1.80 / 1 \mathrm{~b} \mathrm{ThO}_{2}$

\subsubsection{Mine Capital Cost}

The capital cost for the Wet Mountain mine is calculated by scaling down the Lemhi Pass cost estimate with a .75 scaling factor ${ }^{(5)}$. Using this approximation, the capital cost is $\$ 3,463,000$. An additional $\$ 1,000,000$ is added to account for additional exploration necessary due to the scattered nature of this deposit and $\$ 45,700$ is added for effluent control equipment bringing the cost to $\$ 4,508,700$.

\subsubsection{Mine Operating Cost}

Operating costs are estimated to be the same as those from the first 7 years of the Lemhi Pass model (Table 5, Appendix D). Multiplying the value of $\$ 22.17 /$ ton of ore by a production rate of $350 \mathrm{tpd}$, operating costs are calculated to be $\$ 1,940,000$ annually.

\subsubsection{Mi11 Production Costs}

The production costs for milling Wet Mountain thorite is $\$ 5.50 / 1 \mathrm{~b} \mathrm{Th} \mathrm{T}_{2}$. (Table 10.3). The cost assumes a fixed charge rate of .3681 applied to the capital investment. Mill capital and operating costs are described in the following sections.

\subsubsection{Mil1 Capital Costs}

The total capital investment for a 350 tpd thorite mill is estimated at $\$ 10,406,000$. The capital cost is determined by scaling down the Lemhi Pass thorite mill with a 0.70 scaling factor. Capital costs for Wet Mountain mill are summarized in Table 10.4 . 
TABLE 10.3. Wet Mountain Mill Production Costs

Annual Fixed Charges:

Depreciable Capital

Non-Depreciable Capital

Annual Operating Cost

Annual Production Cost

Annual $\mathrm{ThO}_{2}$ Production

Unit Cost of Milling
$\$ 3,523,000$

$\$ 83,000$

$\$ 4,763,000$

$\$ 8,364,000$

$1,528,000$

$\$ 5.50 / 1 \mathrm{~b} \quad \mathrm{ThO}_{2}$

TABLE 10.4. Wet Mountain Mil1 Capital Costs

Total Depreciable Capital Investment

Land

$\$ 9,572,000$

163,000

Working Capital

671,000

TOTAL Capital Investment

$\$ 10,406,000$

\subsubsection{Mil1 Operating Costs}

The components of mill operating costs are shown in Table 10.5. Costs for electric power and fuel oil are scaled down using the 0.7 scaling factor. Operating labor force is estimated at 59 men from data on uranium mills of similar size. Reagents and water consumption are scaled down linearly. 
TABLE 10.5. Wet Mountain Mi11 Operating Cost

Direct Costs

Operating Labor (59 men)

$\$ 951,000$

Supervision

143,000

Maintenance and Repairs

624,000

Operating Supplies

94,000

Laboratory Charges

143,000

Reagents

310,000

Utilities

Fuel $0 i 1$

234,000

Electricity

169,000

Water

27,000

Sulfuric Acid Operating Plant

$\$ 779,000$

Indirect Costs

Plant Overhead

$\$ 1,031,000$

Administrative Costs

$\frac{258,000}{\$ 4,763,000}$

TOTAL Operating Costs

\subsection{MAJOR UNCERTAINTIES}

Major areas of uncertainty affecting the $\mathrm{ThO}_{2}$ unit cost estimates include mine capital and operating costs, mill capital and operating costs, mine capacity, mill capacity, and mill recovery efficiency. Our estimates for the range of uncertainty in these areas are:

Mine Capital Cost

Mine Operating Cost

Mill Capital Cost

Mill Operating Cost

Mine Capacity

Mil1 Capacity

Recovery Efficiency
$+100 \%$ to $-10 \%$ of calculated value $+100 \%$ to $-10 \%$ of calculated value $+50 \%$ to $-10 \%$ of calculated value $+50 \%$ to $-10 \%$ of calculated value 2000 tpd to 200 tpd with most likely value of $350 \mathrm{tpd}$

2000 tpd to 200 tpd with most likely value of $350 \mathrm{tpd}$

$96 \%$ to $40 \%$ with most likely value of $91 \%$ 
The impacts of these uncertainty ranges on the unit cost of $\mathrm{ThO}_{2}$ is shown in Table 10.6. From the incremental unit cost values, a Monte Carlo Statistical Analysis is performed using the procedure described in Section 16. From this analysis, a most $1 \mathrm{ikely}$ value of $\$ 8.30 / 1 \mathrm{~b} \mathrm{ThO}_{2}$ and overall cost range of $\$ 5.92 / 1 \mathrm{~b}$ to $\$ 13.30 / 1 \mathrm{~b}$ is predicted for the unit cost of $\mathrm{ThO}_{2}$ at Wet Mountain.

TABLE 10.6. Uncertainty Ranges for Factors Affecting the $\mathrm{ThO}_{2}$ Unit cost for the Wet Mountains

\begin{tabular}{|c|c|c|}
\hline & $\begin{array}{l}\text { Most Likely } \\
\text { Value } \\
\end{array}$ & Range \\
\hline Mine Capital Cost $510^{3}$, year & $51,232^{(a)}$ & 2,654 to 1,153 \\
\hline Unit Mine Capital Cost S/1b $\mathrm{ThO}_{2}$ & .84 & 1.68 to .75 \\
\hline Incrementa? Unit Cost $s /$ ib $\mathrm{ThO}_{2}$ & & .84 to -.09 \\
\hline Mine Operating Cost $\sin ^{3} /$ year & 1,513 & 3,026 to 1,362 \\
\hline Unit Mine Dperating Cost $\mathrm{S} / 1 \mathrm{~b} \mathrm{ThO}_{2}$ & .99 & 1.98 to .89 \\
\hline Incremental Unit Cost $\$ / 1 \mathrm{~b} \mathrm{ThO}_{2}$ & & +.99 to -.10 \\
\hline Mill Capital Cost $\$ 10^{3} /$ year & 3,606 & 5,409 to 3,245 \\
\hline Unit Mill Capital Cost S/lb $\mathrm{ThO}_{2}$ & 2.36 & 3.54 to 2.12 \\
\hline Incremental Unit cost $5 /$ ib $\mathrm{ThO}_{2}$ & & +1.18 to -.24 \\
\hline Miil Operating Cost $\$ 10^{3}$ /year & 4,763 & 7,144 to 4,287 \\
\hline Unit Miil Capital Cost $5 / 16$ ino 2 & 3.12 & 1.68 to 2.37 \\
\hline Incremental Unit s/ib Tho 2 & & +1.56 to -.31 \\
\hline Mine Capacity tpd & 350 tpd & 2,000 to 200 \\
\hline Unit Mine Capacity Cost $\mathrm{s} / 1 \mathrm{~b} \mathrm{ThO}_{2}$ & & 7.01 to 6.68 \\
\hline Incremental Unit cost $5 / 10 \mathrm{ThO}_{2}$ & & +.21 to -.12 \\
\hline Mill Capacity tpd & $250 \pm p d$ & 2,000 to 200 \\
\hline \multicolumn{3}{|l|}{ Unit Mill Capacity Cost silb $\mathrm{TnO}_{2}$} \\
\hline Incremental Unit Cost $\mathrm{Silb} \mathrm{ThO}_{2}$ & & .29 to -2.03 \\
\hline Mill Recovery Efficiency :' & 91 & 40 to 96 \\
\hline $\begin{array}{l}\text { Unit Recovery Efficiency Cost } S / 1 b \\
\mathrm{ThO}_{2}\end{array}$ & 7.31 & 16.63 to 6.93 \\
\hline Incremental Unit Cost $5 / 1 \mathrm{~b} \mathrm{ThO}_{2}$ & & +9.32 to -.38 \\
\hline
\end{tabular}

(a) Less $22^{\circ}$; depletion ailowance 


\section{REFERENCES}

1. M. H. Staatz, "Thorium Veins in the United States", Economic Geology, Vol. 69, pp. 494-507, 1974.

2. R. A. Christman, et al., Geology and Thorium Deposits of the Wet Mountains, Colorado; A Progress Report, USGS Bulletin 1072-H, pp. 491-535, 1959.

3. F. J. Kelly, Technical and Economic Problems of Rare-Earth-Metal and Thorium Resources in Colorado, New Mexico, and Wyoming, USBM IC 8124 , p. 38, 1961 .

4. M. H. Staatz, United States Mineral Resources, USGS Prof. Paper \#820, p. 474,1973 .

5. Chemical and Operating Cost Estimating System Handbook, Prepared for the United States Dept. of Interior, Bureau of Mines, by STRAAM Engineers, Inc., Arcadia, CA, 374 pp., July 1978. 


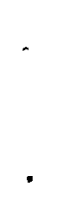




\subsection{THORIUM PRODUCTION FROM PALMER, MICHIGAN}

\subsection{RESOURCE DESCRIPTION}

The Paimer area is located in the east-central portion of Marquette County on the northern peninsula of Michigan. The deposit occupies approximately 3 square miles and includes the town of Palmer. The Palmer area is characterized by relatively rugged, knobby topography covered by a dense forest. Thorium-bearing Goodrich quartzite forms the bulk of the ore deposit. This deposit contains an estimated 193,000 tons of $\mathrm{ThO}_{2}$.

The Goodrich quartzite of the Palmer area is composed of a locally developed basal conglomerate which consists almost entirely of boulders and pebbles of granite. Above the basil unit, alternating beds of coarse quartz$i$ te and pebble conglomerate exist. The monazite concentrations are associated with the pebble conglomerates.

Since surface mining appears to be the most feasible mining method, the monazite is assumed to be evenly distributed throughout the quartzite. The thorium content is estimated at $1.06 \mathrm{~Tb}$ /ton $(.06 \%)$ but ranges from .26 to $3.56 \mathrm{lb} /$ ton $^{(1)}$, while the average monazite content is estimated at $14.7 \mathrm{lbs} /$ ton. The monazite is assumed to be $8.2 \% \mathrm{ThO}_{2}$.

Other heavy minerals associated with the quartzite are mainly hematite, magnetite, ilmenite, and rutile. No estimates are available as to the amount of these minerals. The rare earth oxide content of the monazite is approximately $46 \%(2)$, and, the amount of mineable rare earth oxides contained in the monazite at Palmer is estimated at over 1,000,000 tons. (See Appendix F).

\subsection{MINE DESCRIPTION}

Currentiy, the Palmer, Michigan deposit is not being mined for thorium, al though the Empire Iron Mine is located one mile northwest of the Palmer townsite. The conceptual Palmer, Michigan mine was developed based on information about the deposit. As the Goodrich formation is near the surface, the Palmer, Michigan mine will utilize open pit mining. 
The conceptual mine consists of a pit designed to remove the upper central part of the ore body which contains 123,500 tons of $\mathrm{ThO}_{2}$ in 205 million tons of ore. The pit also contains 55 million tons of waste rock and till. Ten million tpy of ore will be produced from the pit along with about 3 million tons of waste. The mine is designed to operate 3 shifts/day, five days/wk for 240 days/yr for $20 \mathrm{yr}$. Mine equipment and shops are sized for these parameters. Ore recovery is assumed to be approximately $97 \%$.

\subsubsection{Mining Process}

The major process steps for mining are described in the following section.

\subsubsection{Removing the Overburden}

Approximately 30 feet of overlying till must be removed before mining. The till is scraped using bulldozers and the overburden is loaded into trucks using front-end loaders. The waste is then hauled to a dump adjacent to the

pit. The ore is now ready to be mined.

11.2.1.2 Drilling and Blasting

Blast holes are drilled into the ore that constitutes the Palmer deposit using a downhole hammer. The blast holes are loaded with explosives and detonated.

\subsubsection{Loading the Ore}

The ore is loaded into 120-ton electric wheel trucks using $15 \mathrm{yd}^{3}$ shovels. Fifteen cubic yard front end loaders will be provided also to clean up around the shovels.

\subsubsection{Hauling of Ore}

The electric ore trucks transport the carbonatite to a concentrator located approximately one-half mile from the mine. The truck is routed through a scanner to determine ore grade prior to unloading.

\subsubsection{Effluent Control}

The only radioactive solid waste is waste rock from the dry mill and the glacial till overburden. Waste management consists simply of stockpiling the waste rock in a storage pile equipped with wind barriers in a dump site adjacent to the pit. 
The main liquid effluent stream leaving the mine is the mine water. This water is pumped out of the mine at the mill site to a holding pond where it is allowed to settle. It is then recycled for use in the mill or used to wet down haul roads for dust control. Access water will be allowed to drain to natural surface water drainage systems.

The airborne effluents are made up of dust and combustion gases (including blasting gas and equipment exhaust gas). These airborne effluents are given off during blasting, loading, blending, and crushing. The roads and ore piles are periodically wet down to minimize the amount of windblown dust.

\subsection{MILL DESCRIPTION}

Monazite conglomerate has not been processed for any commercial purpose, but laboratory studies have been conducted on the benefication of conglomerate monazite. The overall recoverability of monazite in the Goodrich Quartzite has been reported to be $85 \%{ }^{(2)}$, but no process description was available. Successful laboratory separation of monazite from the Deadwood Conglomerate found at Bald Mountain, Wyoming has also been reported with an overall recovery of $61 \%$. We assume that the concentration process for Bald Mountain also applies to Goodrich Quartzite, thus Palmer, Michigan conglomerate milling utilizes the process described by Borrowman and Rosenbaum ${ }^{(3)}$.

The Palmer, Michigan mill processes 41,700 tpd of ore at the primary crusher and produces approximately 290 tpd of concentrate. The concentrate contains $5.2 \% \mathrm{ThO}_{2}$. The process recovers $61 \%$ of the thorium originally in the ore.

\subsubsection{Milling Process}

The conglomerate milling process consists of crushing followed by gravity and magnetic separation. The process steps for the reference conglomerate mill are described in the following sections. A detailed process flow diaaram is shown in Figure 11.1. 


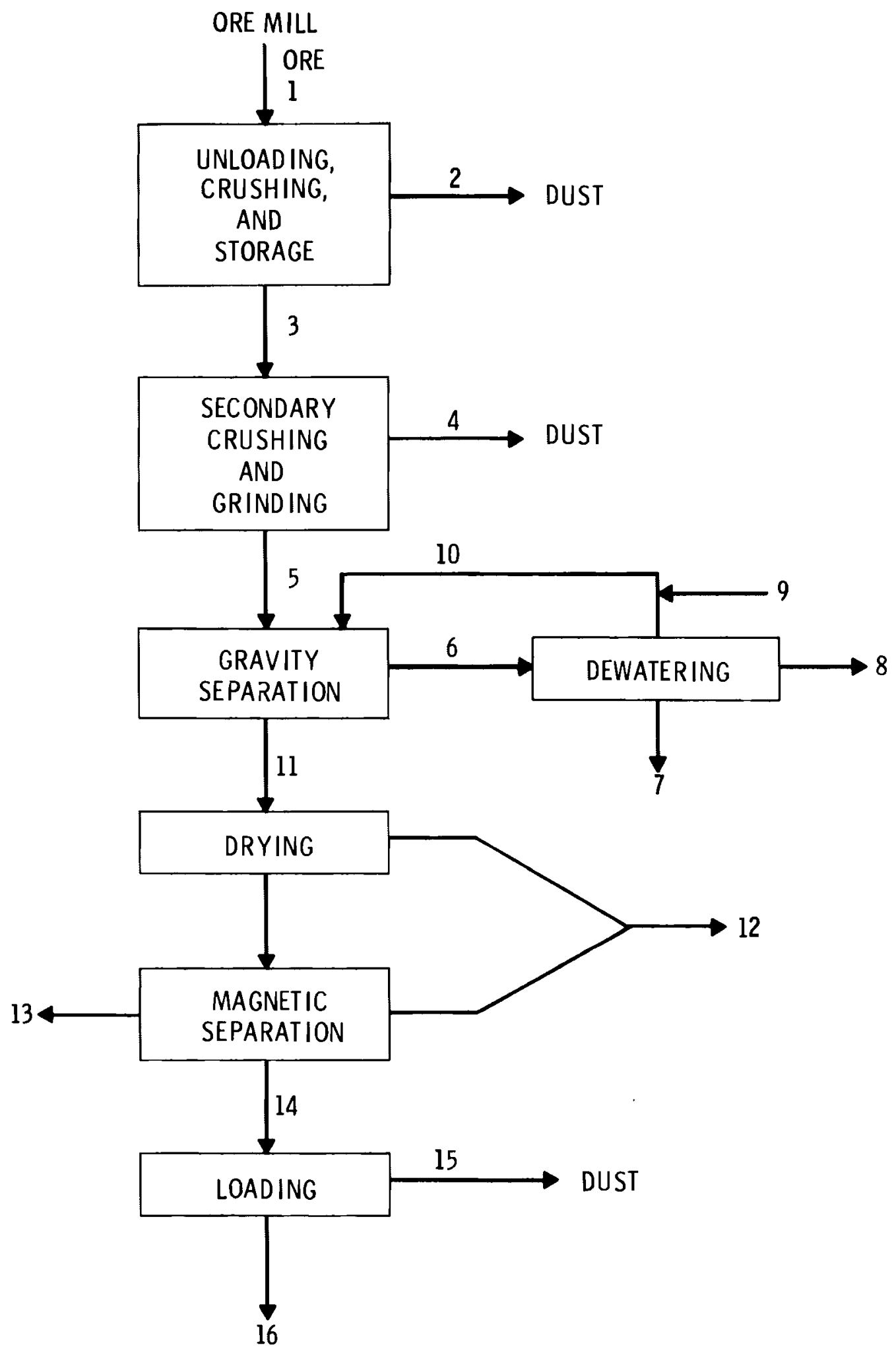

FIGURE 11.1. Palmer Michigan Mi11

11.4 


\section{FLOW STREAMS FOR PALMER, MICHIGAN ORE MILL}

1. 1895.45 tons $/ \mathrm{hr}$ ore $\mathrm{w} /{ }^{232} \mathrm{Th}=.98912 \mathrm{ton} / \mathrm{hr}$

2. $189.545 \mathrm{lb} / \mathrm{hr} \mathrm{w} /{ }^{232} \mathrm{Th}=.0989 \mathrm{lb} / \mathrm{hr}$

3. 1377.27 tons $/ \mathrm{hr}$ ore $\mathrm{w} /{ }^{232} \mathrm{Th}=.7187 \mathrm{ton} / \mathrm{hr}$

4. $137.7 \mathrm{lb} / \mathrm{hr} \mathrm{w} /{ }^{232} \mathrm{Th}=.073 \mathrm{lb} / \mathrm{hr}$

5. 1377.20 tons $/ \mathrm{hr} w /{ }^{232} \mathrm{Th}=.7187 \mathrm{ton} / \mathrm{hr}$

6. 8656.96 tons $/ \mathrm{hr} \mathrm{H} \mathrm{H}_{2} \mathrm{O}$ and 1347.04 tons $/ \mathrm{hr}$ ore $\mathrm{w} /{ }^{232} \mathrm{Th}=.2762 \mathrm{ton} / \mathrm{hr}$

7. 311.13 tons $/ \mathrm{hr} \mathrm{H} \mathrm{H}_{2} \mathrm{O}$ and 1225.78 tons $/ \mathrm{hr}$ ore $\mathrm{w} /{ }^{232} \mathrm{Th}=.2488 \mathrm{ton} / \mathrm{hr}$

8. 779.12 tons $/ \mathrm{hr} \mathrm{H} \mathrm{H}_{2} \mathrm{O}$ and 121.26 tons $/ \mathrm{hr}$ ore $\mathrm{w} /{ }^{232} \mathrm{Th}=.0274 \mathrm{ton} / \mathrm{hr}$

9. 1092.65 tons $/ \mathrm{hr} \mathrm{H}_{2} \mathrm{O}$

10. 8659.36 tons $/ \mathrm{hr} \mathrm{H}_{2} \mathrm{O}$

11. 2.40 tons $/ \mathrm{hr} \mathrm{H} \mathrm{H}_{2} \mathrm{O}$ and 30.16 tons $/ \mathrm{hr}$ ore $\mathrm{w} /{ }^{232} \mathrm{Th}=.4425 \mathrm{ton} / \mathrm{hr}$

12. 2.40 tons $/ \mathrm{hr} \mathrm{H} \mathrm{H}^{\mathrm{O}}$ and $109.98 \mathrm{lb} / \mathrm{hr}$ ore $\mathrm{w} /{ }^{232} \mathrm{Th}=.057 \mathrm{lb} / \mathrm{hr}$

13. 20.60 tons $/ \mathrm{hr} \mathrm{w} /{ }^{232} \mathrm{Th}=8.40 \mathrm{lb} / \mathrm{hr}$

14. 9.505 tons $/ \mathrm{hr} \mathrm{w} /{ }^{232} \mathrm{Th}=876.5 \mathrm{lb} / \mathrm{hr}$

15. $0.95 \mathrm{lb} / \mathrm{hr} \mathrm{w} /{ }^{232} \mathrm{Th}=.044 \mathrm{lb} / \mathrm{hr}$

16. 9.505 tons $/ \mathrm{hr} \mathrm{w} /{ }^{232} \mathrm{Th}=876.5 \mathrm{lb} / \mathrm{hr}$

\section{FIGURE 11.1. (cont'd)}

\subsubsection{Run-of-Mine Storage}

Ore arrives at the mill by truck and is dumped in a storage area. The ore is segregated according to grade, blended to maintain a relatively constant input to the mill, and then transferred from the storage area to the primary crusher conveyor by means of a front-end loader.

\subsubsection{Crushing and Grinding}

The ore is initially crushed in a primary crusher and then transferred to the secondary crusher, which grinds the ore to minus 20 mesh. The discharge is screened and the oversized particles are returned to the secondary crusher. The processed ore is stored in a crushed-ore bunker.

\subsubsection{Gravity Separation}

The crushed ore is mixed with water and is pumped to a rougher shakingtable circuit. The tails are discarded to the tails pond and the milling 
product is processed in the scavenger shaking table circuit. The scavenger shaking table concentrate is returned to the rougher circuit for reprocessing. The rougher circuit concentrate is transferred to the wet-concentrate storage pile for dewatering.

\subsubsection{Drying}

The wet concentrate is transferred from the wet concentrate storage to a rotary dryer using an overhead crane. The concentrate is dryed and discharged to the magnetic separator belt conveyor.

\subsubsection{Magnetic Separation}

The dry concentrate is processed by rougher cross-belt magnetic separators. The tails from the rougher magnetic separator are processed by smaller scavengers magnetic separators in parallel. The tails are discarded and while the concentrate is recycled to the rougher magnetic separator. The final concentrate obtained is discharged to storage until it is shipped to the refinery.

\subsubsection{Effluent Control}

Two types of effluents are generated from the mill. Airborne wastes generated during unloading, crushing and grinding are controlled using 950,000 cyclone dust collection systems. Wet impingement scrubbers control dust from loading, drying, and magnetic separation.

Liquid effluents generated during gravity and magnetic separation are piped to a 200 acre settling pond. Water from the tails pond is recycled to the mill for use in gravity separators.

\subsection{REFINERY DESCRIPTION}

While placer monazite has been successfully mined and refined, conglomerate monazite has not. The conceptual refinery is, therefore, based on a laboratory scale process developed by the United States Bureau of Mines ${ }^{(3)}$. The reference mill has a design capacity of 300 tons of concentrate per day. The process recovers $95 \%$ of the $\mathrm{ThO}_{2}$ and produces a product of $99+\%$ purity. The refinery operates 24 hours/day for 330 days/year for 20 years. The 
refinery is assumed to be located approximately 10 miles from the Palmer mine/mill site.

\subsubsection{Refining Process}

Acid leaching, followed by solvent extraction and caustic digestion, constitute the refining process. The following sections discuss the major steps involved in the refining of conglomerate monazite. A detailed process flow diagram is shown in Figure 11.2.

\subsubsection{Grinding}

The concentrate arrives from the mill by truck and is stored until processing. The concentrate, which has already been crushed to 20-mesh, contains between $1 \%$ and $6 \%$ thorite. Before leaching, the concentrate is dry ground to 100 -mesh in a ball mill.

\subsubsection{Leaching}

The concentrate is mixed with 1.5 times its weight of $96 \% \mathrm{H}_{2} \mathrm{SO}_{4}$ and heated to $200^{\circ} \mathrm{C}$ in agitated tanks for $2 \mathrm{hr}$. The concentrate is then mixed with 5 parts water and agitated for $1 \mathrm{hr}$. The pregnant solution is filtered and washed with acidified water.

\subsubsection{Liquid/Solid Separation}

After the acid leaching process the pregnant solution contains $6 \%$ solids. It is flocculated with 0.2 lb of flocculate per ton of concentrate. After filtration using a leaf type pressure filter, the pregnant liquor is then transferred to the solvent extract process.

\subsubsection{Solvent Extraction}

Thorium in the leach liquor is extracted using an organic solvent with 10\% aliphatic primary amine, 5\% Primary decyl alcohol (PDA) and 85\% kerosene. The leach liquor and the organic solvent are brought into contact in the mixer settler for 15 minutes. The barren leach solution is discarded and the loaded organic is scrubbed in mixer/settlers with $0.2 \mathrm{M}$ sulfuric acid for removal of rare earth oxides. 


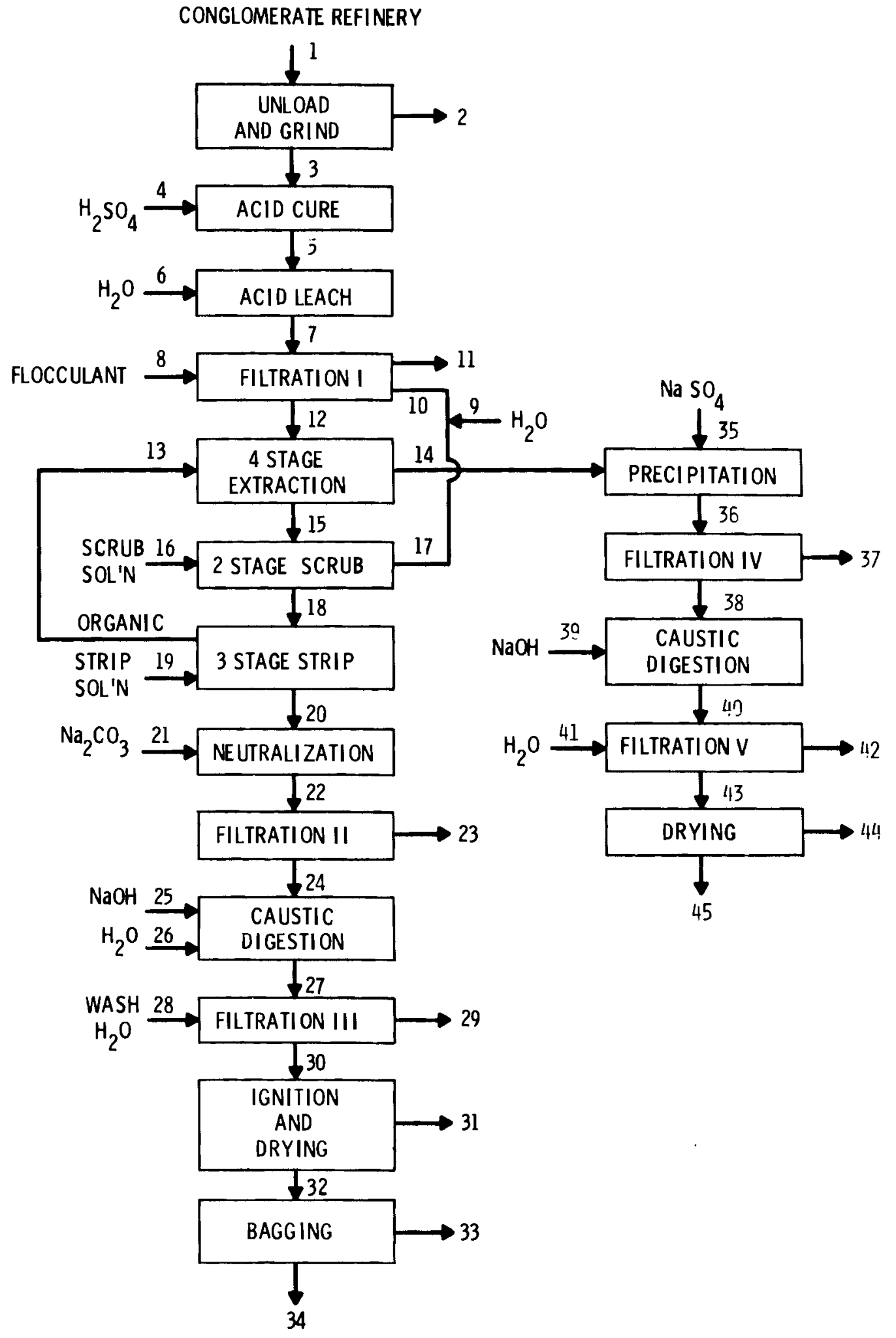

FIGURE 11.2. Palmer Michigan Refinery 
FLOW STREAMS FOR PALMER, MICHIGAN REFINERY

1. 9.505 tons $/ \mathrm{hr}$ concentrate $\mathrm{w} /{ }^{232} \mathrm{Th}=876.48 \mathrm{1b} / \mathrm{hr}$

2. $.9505 \mathrm{lb} / \mathrm{hr} \mathrm{w} /{ }^{232} \mathrm{Th}=.044 \mathrm{lb} / \mathrm{hr}$

3. 9.505 tons $/ \mathrm{hr} \mathrm{w} /{ }^{232} \mathrm{Th}=876.436 \mathrm{bb} / \mathrm{hr}$

4. 16.01 tons $/ \mathrm{hr} \mathrm{H}_{2} \mathrm{SO}_{4}$

5. 25.51 tons $/ \mathrm{hr} \mathrm{w} /{ }^{232} \mathrm{Th}=876.436 \mathrm{lb} / \mathrm{hr}$

6. 47.525 tons $/ \mathrm{hr} \mathrm{H}_{2} \mathrm{O}$

7. 73.035 tons $/ \mathrm{hr} \mathrm{w} /{ }^{232} \mathrm{Th}=876.436 \mathrm{lb} / \mathrm{hr}$

8. $1.90 \mathrm{lb} / \mathrm{hr}$ flocculant

9. 24.71 tons $/ \mathrm{hr} \mathrm{H}_{2} \mathrm{O}$

10. 48.47 tons $/ \mathrm{hr}$ wash solution $\mathrm{w} /{ }^{232} \mathrm{Th}=0.7788 \mathrm{lb} / \mathrm{hr}$

11. 26.46 tons $/ \mathrm{hr} w /{ }^{232} \mathrm{Th}=30.254 \mathrm{lb} / \mathrm{hr}$

12. 121.505 tons $/ \mathrm{hr} \mathrm{w} /{ }^{232} \mathrm{Th}=846.96 \mathrm{lb} / \mathrm{hr}$

13. 71.29 tons $/ \mathrm{hr}$ organic (10\% JM-T, 5\% PDA, $85 \%$ kerosene)

14. 121.505 tons $/ \mathrm{hr} w /{ }^{232} \mathrm{Th}=1.55 \mathrm{lb} / \mathrm{hr}$

15. 71.29 tons $/ \mathrm{hr} \mathrm{w} /{ }^{232} \mathrm{Th}=845.41 \mathrm{lb} / \mathrm{hr}$

16. 23.76 tons $/ \mathrm{hr}$ of scrub solution $\left(0.2 \mathrm{M} \mathrm{H}_{2} \mathrm{SO}_{4}\right)$

17. 23.76 tons $/ \mathrm{hr} w /{ }^{232} \mathrm{Th}=0.779 \mathrm{lb} / \mathrm{hr}$

18. 71.29 tons $/ \mathrm{hr} w /{ }^{232} \mathrm{Th}=844.63 \mathrm{lb} / \mathrm{hr}$

19. 38.02 tons $/ \mathrm{hr}$ strip solution $(1.5 \mathrm{M} \mathrm{NaCl}, .5 \mathrm{M} \mathrm{HCl})$

20. 38.02 tons $/ \mathrm{hr} \mathrm{w} /{ }^{232} \mathrm{Th}=844.63 \mathrm{lb} / \mathrm{hr}$

21. .9505 ton $/ \mathrm{hr} \mathrm{Na}{ }_{2} \mathrm{CO}_{3}$

22. 38.9705 tons $/ \mathrm{hr} w / 232 \mathrm{Th}=844.63 \mathrm{lb} / \mathrm{hr}$

23. 38.02 tons $/ \mathrm{hr} w /{ }^{232} \mathrm{Th}=0.7791 \mathrm{~b} / \mathrm{hr}$

24. .9505 ton $/ \mathrm{hr} w /{ }^{232} \mathrm{Th}=843.85 \mathrm{lb} / \mathrm{hr}$

25. $285.15 \mathrm{lb} / \mathrm{hr} \mathrm{NaOH}$

26. 1.90 tons $/ \mathrm{hr} \mathrm{H} \mathrm{H}_{2} \mathrm{O}$

27. 2.993 tons $/ \mathrm{hr} \mathrm{w} /{ }^{232} \mathrm{Th}=843.85 \mathrm{lb} / \mathrm{hr}$

28. 1.90 tons $/ \mathrm{hr}$ wash solution

29. 3.80 tons $/ \mathrm{hr} \mathrm{w} /{ }^{232} \mathrm{Th}=.080 \mathrm{lb} / \mathrm{hr}$

30. 1.093 tons $/ \mathrm{hr} w /{ }^{232} \mathrm{Th}=843.77 \mathrm{lb} / \mathrm{hr}$

31. 0.609 tons $/ \mathrm{hr} w /{ }^{232} \mathrm{Th}=0.803 \mathrm{lb} / \mathrm{hr}$

32. $968.0 \mathrm{lb} / \mathrm{hr} \mathrm{w} /{ }^{232} \mathrm{Th}=842.967 \mathrm{lb} / \mathrm{hr}$

33. $0.1596 \mathrm{lb} / \mathrm{hr} w /{ }^{232} \mathrm{Th}=.139 \mathrm{lb} / \mathrm{hr}$

34. $967.84 \mathrm{lb} / \mathrm{hr} \mathrm{w} /{ }^{232} \mathrm{Th}=842.831 \mathrm{lb} / \mathrm{hr}$

35. 5.7 tons $/ \mathrm{hr} \mathrm{NaSO}$

36. 127.205 tons $/ \mathrm{hr} w /{ }^{232} \mathrm{Th}=1.55 \mathrm{lb} / \mathrm{hr}$

37. 94.9 tons $/ \mathrm{hr} w /{ }^{232} \mathrm{Th}=1.05 \mathrm{lb} / \mathrm{hr}$

38. 32.3 tons $/ \mathrm{hr} w /{ }^{232} \mathrm{Th}=0.50 \mathrm{lb} / \mathrm{hr}$

39. 9.1 tons $/ \mathrm{hr} \mathrm{NaOH} \mathrm{(30 \% )}$

40. 41.4 tons $/ \mathrm{hr} \mathrm{w} /{ }^{232} \mathrm{Th}=.50 \mathrm{lb} / \mathrm{hr}$

41. 10.2 tons $/ \mathrm{hr} \mathrm{H}_{2} \mathrm{O}$

42. 41.0 tons $/ \mathrm{hr} \mathrm{w} /{ }^{232} \mathrm{Th}=.11 \mathrm{lb} / \mathrm{hr}$

43. 10.6 tons $/ \mathrm{hr} w /{ }^{232} \mathrm{Th}=0.39 \mathrm{lb} / \mathrm{hr}$

44. 3.2 tons $/ \mathrm{hr} w /{ }^{232} \mathrm{Th}=.0062 \mathrm{lb} / \mathrm{hr}$

45. 7.4 tons $/ \mathrm{hr} \mathrm{w} /{ }^{232} \mathrm{Th}=.384 \mathrm{lb} / \mathrm{hr}(46 \% \mathrm{REO})$

\section{FIGURE 11.2. (cont'd)}




\subsubsection{Salt Stripping}

A salt solution is used to strip the thorium from the loaded organic. The loaded organic and the salt solution are brought into contact in three stainless steel agitated tanks. The premixed salt solution containing 1.5 normal sodium chloride and 0.5 normal hydrochloride acid removes the thorium from the organic. The organic is returned to the amine extraction step. The loaded strip liquor is pumped to the neutralization process.

\subsubsection{Neutralization}

The loaded strip liquor is neutralized with soda ash in an agitated tank and the thorium precipitates out of solution. The precipitate is dewatered using a rotary drum filter. The filtrate is discarded.

\subsubsection{Caustic Digestion}

The dewatered precipitate is pumped to a stainless steel agitated tank where the precipitate is digested with caustic soda at room temperature. The caustic digestion forms hydrus thorium oxide which is removed from the caustic solution with a continuous rotary drum filter. The filtrate is discarded.

\subsubsection{Drying and Ignition}

The hydrous thorium oxide is dried to $10 \%$ moisture content in a twinscrew dryer which operates with a jacket temperature of $120^{\circ} \mathrm{C}$ and a screw temperature of $154^{\circ} \mathrm{C}$. The twin-screw dryer discharges thorium hydroxide into a rotary kiln where it is converted to $\mathrm{Th}_{2}$. The kiln operates at $850^{\circ} \mathrm{C}$ and runs $7 \%$ full $^{(4)}$. The discharge from the rotary $k i l n$ is $\mathrm{ThO}_{2}$ of $99+\%$ purity. The $\mathrm{ThO}_{2}$ is packaged in drums and shipped to the fabrication facility.

\subsubsection{Byproduct Recovery}

The raffinate from the solvent extraction phase contains the rare earth oxides. To precipitate the rare earths, $60 \mathrm{~g} / \mathrm{l}$ of sodium sulfate is added to the raffinate. Ninety-eight percent of the rare earth byproducts are converted to the sulfate salt. The rare earth sulfates are treated with caustic soda, and a rare earth hydroxide precipitate is formed. The precipitate is dried at $140^{\circ} \mathrm{C}$. Product purity is estimated at $46 \%$ rare earth oxides ${ }^{(3)}$. 


\title{
11.4.2 Effluent Control
}

Effluent control methods are similar to those utilized for the Lemhi Pass refinery. They are described in Section 8.3.2 of this report.

11.4.3 Sulfuric Acid Plant

In order to reduce the cost of sulfuric acid, an on-site sulfuric acid plant is included with the refinery.

\subsection{PALMER, MICHIGAN PRODUCTION COSTS}

The production costs for developing an estimated 70,000 tons of $\mathrm{ThO}_{2}$ from Palmer, Michigan is $\$ 12.88 / 1 \mathrm{~b} \mathrm{ThO}_{2}$. After taking into account uncertainties in mine capital and operating costs, refinery capital and operating costs, and thorium recovery, a unit cost of $\$ 14.20 / 1 \mathrm{~b} \mathrm{Th} \mathrm{O}_{2}$ is estimated from the method described in Section 16. These costs, (Table 11.1) are developed in the following sections.

\section{TABLE 11.1. Palmer Production Cost Summary}

\author{
Unit Cost \\ $\left(\$ / 1 \mathrm{~b} \quad \mathrm{ThO}_{2}\right)$ \\ Mining/Milling \\ 10.90 \\ Refining \\ 2.00 \\ Total from Estimates \\ 12.90 \\ Total Including Uncertainty \\ 14.20

\subsubsection{Mine/Mill Production Costs} \\ The production costs for Palmer, Michigan mines are shown in Table 11.2. \\ Capital and operating costs were developed by a mining consulting firm and \\ are shown in Appendix E. A fixed charge rate of .2338 was assumed to amor- \\ tize capital investment over 20 years.
}


TABLE 11.2. Palmer Mine/M111 Production Costs

Annual Fixed Charges:

Depreciable Capital

$\$ 42,792,000$

Non-Depreciable Capital

$2,123,000$

Annual Operating Costs

$44,747,000$

Subtotal

$\$ 89,662,000$

Depletion Al lowance

$19,726,000$

Annual Production Costs

$\$ 69,936,000$

Annual Levelized Production of $\mathrm{ThO}_{2}$

$6,432,0001 \mathrm{bs}$

Unit Cost of Mining/Milling

$\$ 10.87 / 1 \mathrm{~b}$

\subsubsection{Mine/Mill Capital Costs}

Capital costs for the mine and mill were determined jointly. (See Appendix E). Total capital costs are approximately $\$ 204,258,000$ (Table 11.3).

TABLE 11.3. Palmer Mine/Mill Capital Cost

Mine/Mill Buildings and Equipment

$\$ 159,720,000$

Effluent Control Buildings and Equipment cost

407,000

Mine Tailings Pond

236,000

Mill Tailings Pond

$7,220,000$

Exploration

$2,977,000$

Development

$11,462,000$

Environmental Impact

Tota1 Depreciable Capital Investment $1,006,000$ Land

Total Capital Investment

$\$ 183,028,000$

$21,230,000$

$\$ 204,258,000$

11.5.1.2 Palmer Mine/Mill Operating Costs

Combined operating costs for the mine and mill are approximately $\$ 44,747,000$ annually (Table 11.4). These costs were developed in Appendix E. 


\section{TABLE 11.4. Palmer Mine/Mi11 Operating Costs}

Mine Labor Costs (a)

$$
\begin{array}{r}
\$ 6,006,000 \\
7,770,000 \\
2,046,000 \\
6,424,000 \\
12,848,000 \\
7,000,000 \\
2,653,000 \\
\hline \$ 44,747,000
\end{array}
$$$$
\text { Mine Equipment Replacement }
$$$$
\text { Materials and Supplies }
$$$$
\text { Mill Equipment Replacement }
$$$$
\text { Mine/Mill Effluent Control Annual cost }
$$$$
\text { TOTAL }
$$

(a) Includes overhead.

\subsubsection{Refinery Production Costs}

The refining costs for the Palmer, Michigan ore is $\$ 2.00 / 1 \mathrm{~b} \mathrm{Th0}{ }_{2}$. (Table 11.5) A fixed charge rate of .2338 was applied to nondepreciable capital investment. A fixed charge of $10 \%$ was applied to land and working capital.

\section{TABLE 11.5. Palmer Refinery Production Costs}

Annual Fixed Charges:

Depreciable Capital

Non-Depreciable Capital

Annual Operating Cost

Subtotal

Annual Transportation cost

Annual Production Cost

Annual Levelized Production of $\mathrm{ThO}_{2}$

Unit cost of Refining
$\$ 3,935,000$

217,000

$8,519,000$

$\$ 12,671,000$

320,000

$\$ 12,991,000$

$6,432,000$ lbs

$\$ 2.00 / 1 \mathrm{~b} \mathrm{ThO} 2$

\subsubsection{Refinery Capital Cost}

The total capital investment for the Palmer, Michigan refinery is estimated to be $\$ 19,000,000$ (Table 11.6). The refinery capital cost and effluent 
control equipment capital cost were estimated using the procedure described in Section 6.0. The capital cost of the sulfuric acid plant was estimated from Guthrie ${ }^{(6)}$ based on annual acid consumption of 110,000 tpd.

\section{TABLE 11.6. Palmer Refinery Capital Costs}

Refinery Buildings and Equipment Cost

$\$ 9,116,000$

Effluent Control Buildings and Equipment Cost

146,000

Sulfuric Acid Plant Buildings and Equipment cost

$4,123,000$

Access Road

100,000

Feasibility Study

100,000

Tailings Pond

$1,216,000$

Environmental Impact

100,000

Contingency ( $15 \%$ of DPC)

TOTAL Depreciable Capital Investment

Land

Working Capital (15\% of DPC)

TOTAL Capital Investment

$$
\frac{1,941,000}{\$ 16,832,000}
$$

227,000

$1,941,000$

$\$ 19,000,000$

\subsubsection{Refinery Operating Costs}

The annual operating costs for the 300 tpd Palmer, Michigan, conglomerate refinery are estimated to be $\$ 8,519,000$ (Table 11.7). Maintenance supplies, plant supplies, and overheads were estimated using the procedure described in Section 6.0. Refinery labor, reagent expenses, utilities, and sulfuric acid plant operating costs will be discussed below.

\subsubsection{Refinery Labor Cost}

The refinery operating labor force was derived from the operator requirements for each piece of equipment. The total operating labor was calculated by adding the labor requirements of each component. Individual component requirement was estimated from Blecker and Nichols ${ }^{(5)}$. The total requirement for operators was estimated to be $11 \mathrm{men} / \mathrm{shift}$ which includes two floaters. Hourly cost of operating labor is assumed to be $\$ 8.06 / \mathrm{hr}$. 
TABLE 11.7. Palmer Refinery Operating Costs

Direct Costs

Operating Labor (33 men)

$\$ 702,000$

Supervisory and Clerical

105,000

Maintenance and Repairs

$1,140,000$

Operating Supplies

171,000

Laboratory Charges

105,000

Utilities

Electricity

306,000

Fuel 0 il

473,000

Water

21,000

Reagents

$\$ 2,494,000$

Indirect Costs

Plant Overhead

$\$ 1,168,000$

Administrative Overhead

292,000

Sulfuric Acid Operating cost

$\$ 1,542,000$

TOTAL Operating Cost

$\$ 8,519,000$

\subsubsection{Reagent Expense}

Reagent expenses were calculated by estimating the annual consumption of each reagent and multiplying by the current cost of the reagent. Since a sulfuric acid plant is provided, no expense for sulfuric acid is included. Table 11.8 presents reagent consumption, unit cost and annual reagent cost for the monazite conglomerate refinery. The total reagent expense was estimated to be $\$ 2,494,000$.

\subsubsection{Sulfuric Acid Plant Operating Expense}

The operating expenses for the sulfuric acid plant (raw materials, operating supplies, maintenance materials, labor, supervision, utilities, and indirect costs) were estimated from Guthrie ${ }^{(6)}$ for an 110,000 ton/day sulfuric acid plant. The operating cost was estimated to be $\$ 1,542,000$. 
TABLE 11.8. Palmer Reagent Consumption and Expense

\begin{tabular}{|c|c|c|c|c|}
\hline Reagent & $\begin{array}{c}\text { Annual } \\
\text { Consumption } \\
\end{array}$ & $\begin{array}{c}\text { Annual } \\
\text { Consumption }\end{array}$ & Unit Cost & Annual Cost \\
\hline $\mathrm{NaCl}$ & $6,700 \mathrm{lb} / \mathrm{hr}$ & 26,500 tons $/ y r$ & $\$ 41 /$ ton & $\$ 1,086,000$ \\
\hline $\mathrm{HCl}$ & $1,400 \mathrm{lb} / \mathrm{hr}$ & 5,500 tons $/ y r$ & $\$ 61 /$ ton & 335,000 \\
\hline Soda Ash & $1,900 \mathrm{lb} / \mathrm{hr}$ & 7,524 tons $/ y r$ & $\$ 69 /$ ton & 519,000 \\
\hline $\mathrm{NaOH}$ & $290 \mathrm{lb} / \mathrm{hr}$ & 1,100 tons/yr & $\$ 480 /$ ton & 528,000 \\
\hline Kerosene & $8.1 \mathrm{gals} / \mathrm{hr}$ & $64,152 \mathrm{gal} / \mathrm{yr}$ & $\$ 0.4 / g a 1$ & 26,000 \\
\hline & \multicolumn{3}{|c|}{ TOTAL Annual Reagent Expense } & $\$ 2,494,000$ \\
\hline
\end{tabular}

\subsubsection{Utilities}

Electric power demand was calculated by adding the electric power demand for each equipment component. The annual power cost was calculated to be $\$ 306,000$ assuming a power factor of 0.9 , a distribution factor of 0.9 , and a power cost of $\$ 0.03 / \mathrm{kWh}$.

No. 6 fuel oil demand was estimated by calculating the fuel oil demand for the utility boiler and rotary calciner. The utility boiler was sized to provide steam for space heating, the twin screw dryer, and heating of the leaching tanks. The total demand for fuel oil was 946,000 gpy with an assumed cost of $\$ 0.5 / \mathrm{gal}$. The annual cost of No. 6 fuel oil is $\$ 473,000$.

Water demand was calculated from the process flow charts as $140,000,000$ assuming a cost of $\$ 0.15 / 1000$ gallons ${ }^{(4)}$. The annual expense for water is $\$ 21,000$.

\subsubsection{Transportation Cost}

The transportation cost for hauling the ore from the mill to the refinery is assumed to be $\$ 300,000$ per year. Assuming a haul distance of $10 \mathrm{miles}$, two 30 ton haul trucks will move 290 tpd of concentrate. The capital cost of the trucks is estimated to be $\$ 320,000$. The useful life of the trucks is assumed to be 5 years. The operating costs are summarized in Table 11.9. 
TABLE 11.9. Transportation Cost

Annual Transportation Cost

\begin{tabular}{lr} 
Fixed Charge & $\$ 110,000$ \\
Operating Labor & 120,000 \\
Labor Overhead & 40,000 \\
Maintenance & 20,000 \\
Fue & 30,000 \\
\multicolumn{1}{l}{ TOTAL } & $\$ 320,000$
\end{tabular}

\subsubsection{Byproduct Credit}

Due to the high consumption of sodium hydroxide necessary to precipitate the rare earths, they are not economic to recover. Operating costs would exceed revenue by approximately $\$ 5,100,000 / \mathrm{yr}$ or $\$ .80 / 1 \mathrm{~b} \mathrm{ThO}_{2}$. The conceptual process to recover rare earths is discussed in the following sections.

\subsubsection{Byproduct Production Cost}

The incremental production cost of byproducts is approximately $\$ 16,130,000$ (Table 11.10). A fixed charge rate of .2338 was applied to depreciate capital investment over 20 years. A fixed charge of $10 \%$ was applied to land and working capital.

TABLE 11.10. Incremental cost of Byproducts

Annual Fixed Charges:

Depreciable Capital

Non-Depreciable Capital

$\$ 1,321,000$

79,000

Annual Operating Cost

$14,730,000$

Annual Production Cost

$\$ 16,130,000$

\subsubsection{Capital Costs for Rare Earth Recovery}

The estimated additional capital cost associated with recovering byproducts is summarized in Table 11.11. This cost is approximately $\$ 6,437,000$. 
TABLE 11.11. Components of Byproduct Capital Cost

Buildings and Equipment Cost

$\$ 4,847,000$

Feasibility Study

100,000

Contingency

704,000

Total Depreciable Capital Investment

$\$ 5,651,000$

Land

82,000

Working Capital

704,000

TOTAL Capital Investment

$\$ 6,437,000$

\subsubsection{Operating Cost for Rare Earth Recovery}

Incremental byproduct operating costs are approximately $\$ 14,730,000$

(Table 11.12). Labor costs are based on the number of operators necessary for equipment operation. Supervision, maintenance, repairs, operating supplies, laboratory charges, utilities, and indirect costs are estimated using the procedure described in Section 6.0. Reagent expense is discussed below.

\section{TABLE 11.12. Annual Operating Costs of Byproduct Recovery}

Direct Costs

Operating Labor (4 man/shift)

$\$ 271,000$

Supervision

41,000

Maintenance and Repairs

386,000

Operating Supplies

57,000

Utilities

500,000

Laboratory Charges

41,000

Reagents

$\frac{12,910,000}{\$ 14,206,000}$

Indirect costs

Plant Overhead

419,000

Administrative Overhead 105,000

$\$ 14,730,000$ 


\subsubsection{Reagent Expense}

Reagent cost estimates are based on process information ${ }^{(3)}$ and theoretical consumption requirements. These costs are summarized below.

\begin{tabular}{llll} 
Reagent & \multicolumn{1}{c}{ Consumption } & Unit Cost & Annual Cost \\
$\mathrm{NaOH}$ & 22,000 tons $/ y r$ & $\$ 480 /$ ton & $\$ 10,560,000$ \\
$\mathrm{Na}_{2} \mathrm{SO}_{4}$ & 45,000 tons $/ \mathrm{yr}$ & $\$ 51.9 /$ ton & $\frac{2,350,000}{}$
\end{tabular}

\subsection{MAJOR UNCERTAINTIES}

Major areas of uncertainty affecting the $\mathrm{ThO}_{2}$ unit cost estimates include mine/mill capital and operating costs, refinery capital and operating costs, and thorium recovery. Our estimates for the ranges of uncertainty in these areas are:

Mine/Mill Capital Cost

Mine/Mil1 Operating Cost

Refinery Capital Cost

Refinery Operating Cost

Thorium Recovery Efficiency
$+50 \%$ to $-10 \%$ of calculated value $+50 \%$ to $-10 \%$ of calculated value $+50 \%$ to $-10 \%$ of calculated value $+50 \%$ to $-10 \%$ of calculated value $50 \%$ to $62 \%$ with a most 1 ikely value of $56 \%$

The impact of these uncertainty ranges on the unit cost of $\mathrm{ThO}_{2}$ is shown in Table 11.13. From the incremental unit cost values, a Monte Carlo Statistical Analysis is performed using the procedure described in Section 16. From this analysis, a most likely value of $\$ 14.20 / 1 \mathrm{~b} \mathrm{Th0_{2 }}$ and overall cost range of $\$ 9.90 / 1 \mathrm{~b}$ to $17.10 / 1 \mathrm{~b} \mathrm{ThO}_{2}$ is predicted for the unit cost of $\mathrm{ThO}_{2}$. 
TABLE 11.13. Uncertainty Ranges for Factors Affecting $\mathrm{ThO}_{2}$ Unit Cost

Most Likely

Mine/Mill Capital Cost $\$ 10^{3} /$ year

Unit Mine/Mi11 Capital Cost $\$ / 1 \mathrm{~b} \mathrm{ThO}_{2}$

Incremental Unit Cost $\$ / 1 \mathrm{~b} \mathrm{ThO}_{2}$

Mine/Mill Operating Cost $\$ 10^{3} /$ year

Unit Mine/Mill Operating Cost $\$ / 1 \mathrm{~b} \mathrm{ThO}_{2}$

Incremental Unit Cost $\$ / 1 \mathrm{~b} \mathrm{ThO}_{2}$

Refinery Capital Cost $\$ 10^{3} /$ year

Unit Refinery Capital Cost $\$ / 1 \mathrm{~b} \mathrm{ThO}_{2}$

Incremental Unit Cost $\$ / 1 \mathrm{~b} \mathrm{ThO}_{2}$

Refinery Operating Cost $\$ 10^{3} /$ year

Unit Refinery Operating Cost $\$ / 1 \mathrm{~b} \mathrm{ThO}_{2}$

Incremental Unit cost $\$ / 1 \mathrm{~b} \mathrm{ThO}_{2}$

Thorium Recovery Efficiency (\%)

Unit Recovery Efficiency Cost $\$ / 1 \mathrm{~b} \mathrm{ThO}_{2}$

Incremental Unit cost $\$ / 1 \mathrm{~b} \mathrm{Th0} 2$
Range

$35,034^{(a)}$
5.45

$34,903^{(a)}$

5.43

4,152

.65

8,519

1.32

56

12.88

\begin{tabular}{r} 
Range \\
\hline 52,551 to 31,530 \\
8.17 to 4.90 \\
+2.72 to -.55 \\
52,354 to 31,412 \\
8.14 to 4.88 \\
+2.71 to -.55 \\
6,228 to 3,737 \\
.97 to .58 \\
+.32 to -.07 \\
12,779 to 7,667 \\
1.99 to 1.19 \\
+.67 to -.13 \\
50 to 62 \\
14.43 to 11.63 \\
+1.55 to -1.25
\end{tabular}

(a) Depletion allowance (22\%) is subtracted from cost 


\section{REFERENCES}

1. J. E. Gair, Bedrock Geology and Ore Deposits of the Palmer Quadrangle. Professional Paper 769, U.S. Geological Survey, Marquette County, MI, 1975.

2. R. C. Vickers, "Geology and Monazite Content of the Goodrich Quartzite, Palmer Area, Marquette County, Michigan", in Contributions to the Geology of Uranium. Bulletin 1030-F, U.S. Geological Survey, pp. 171-185, 1956.

3. S. R. Borrowman and J. B. Rosenbaum, Recovery of Thorium From A Wyoming Ore. U.S. Bureau of Mines Report Inv. 5917, p. 8, 1962.

4. H. R. Perry and C. H. Chilton, Chemical Engineering Handbook. McGrawHill Book Company, New York, NY, 1971.

5. H. G. Flecker, T. M. Nichols, Capital and Operating Costs of Pollution Control Equipment Modules, EPA-R5-73-023b, Report to the Environmental Protection Agency by Icarus Corp., Silverspring, MD, 183 pp. July 1973.

6. R. M. Guthrie, Process Plant Estimating Evaluation and Control. Craftman Book Company of America, 1974.

7. J. G. Cannon, "Rare Earths - '76 Was Slow; Pickup Seen for '77". Engineering and Mining Journal, 178(3):183-186, March 1977.

8. D. W. Gentry and M. J. Hrebar, "Procedure for Determining Economics of Mines". Minerals Industry Bulletin, 19(1), Colorado School of Mines.

9. M. S. Peters and R. D. Timmerhaus, Plant Design and Economics for Chemical Engineers. McGraw Hi11 Book Company, New York, NY, 1968. 


\subsection{THORIUM PRODUCTION FROM BEAR LODGE, WYOMING}

\subsection{RESOURCE DESCRIPTION}

Located about 6 miles north of Sundance, Wyoming and occupying 1.5 square miles, the Bear Lodge deposit contains about 228,000 tons of $\mathrm{ThO}_{2}$. Disseminated veinlets of thorium occur in iron-manganese zones. The grade of rock containing the veinlets ranges from $46 \mathrm{ppm} \mathrm{ThO}_{2}$ to $1,200 \mathrm{ppm} \mathrm{ThO}_{2}$. Principal identified thorium-bearing minerals are brockite, monazite and thorite. Rare earths are also contained in the mineralization at concentrations ranging from 12,000 to $18,000 \mathrm{ppm}$ total rare earth oxides. (1)

\subsection{MINE DESCRIPTION}

Three possible sites for an open pit mine are located in the north, central, and south blocks of the Bear Lodge deposits. The average grade of the north block is .023\% $\mathrm{ThO}_{2}$ and $.75 \%$ rare earth oxides. The central block averages $.042 \% \mathrm{ThO}_{2}$ and $1.71 \%$ rare earth oxides. The south block contains $.035 \% \mathrm{ThO}_{2}$ and $1.35 \%$ rare earth oxides $(1)$.

The open pit mines shall be modeled after the Palmer, Michigan mine. Each mine shall operate 3 shifts/day, 5 days/week, for 240 days/year. Since tonnages for each pit are unknown, we assume approximately 51,700 tpd of material will be mined from each pit to recover $41,700 \mathrm{tpd}$. Thus, a total of 155,000 tpd of material or 125,000 tpd of ore will be mined.

\subsubsection{Mining Process}

The mining process for the Bear Lodge mine is similar to the process utilized for Palmer, Michigan mine. The mining process is described in Section 11.2.1 of this report.

\subsection{MILL DESCRIPTION}

The Bear Lodge deposit is not currently processed for thorium and laboratory studies on the benefication of thorium are not available. Since the mineralization at Bear Lodge is extremely fine grained, many separations processes such as gravity and flotation would be impractical. Thorium is, 
therefore, assumed to be submitted to the milling process developed for the thorites using a dilute, sulfuric acid leach. The thorite would probably be the primary mineral amenable to acid attack. Recovery is assumed to be $60 \%$ because the thorium contained in the monazite would be almost inert to the low concentration of acid.

The Bear Lodge mill is assumed to process $125,000 \mathrm{tpd}$ of ore and produce 25 tpd of $\mathrm{ThO}_{2}$. The mill operates 3 shifts/day, 240 days/yr, for $20 \mathrm{yr}$ and produces $\mathrm{ThO}_{2}$ of $99+\%$ purity.

\subsubsection{Milling Process}

The milling process is described in Section 8.3.1 of this report. However we assumed the equipment would be modified to account for the large scale of this operation. Therefore, equipment will be comparable to the Conway Granite refining equipment described in Section 14.3.1 of this report.

\subsection{BEAR LODGE PRODUCTION COST}

The production costs for developing an estimated 137,000 tons of $\mathrm{ThO}_{2}$ from Bear Lodge range from $\$ 53.20 / 1 \mathrm{~b}$ to $\$ 56.80 / 1 \mathrm{~b}$. After taking into account uncertainties in mine capital and operating costs, mill capital and operating costs, and thorium recovery efficiency, a most likely cost of $\$ 56.70$ to 57.80 was determined by the method described in Section 16 . The costs from Table 12.1 are developed in the following sections.

\section{TABLE 12.1. Bear Lodge Production Cost Summary}

\begin{tabular}{|c|c|c|c|}
\hline & North & Central & South \\
\hline Mining & $\$ 7.86$ & $\$ 4.31$ & $\$ 5.17$ \\
\hline Milling & 48.92 & 48.92 & 48.92 \\
\hline Total from Estimates & $\$ 56.80$ & $\$ 53.20$ & $\$ 54.10$ \\
\hline Total (Including Uncertainty) & $\$ 57.80$ & $\$ 56.80$ & $\$ 57.70$ \\
\hline
\end{tabular}

\subsubsection{Mine Production Cost}

The production cost for mining the Bear Lodge resource range from $\$ 4.30 / 1 \mathrm{~b}$ $\mathrm{ThO}_{2}$ to $\$ 7.90 / 1 \mathrm{~b} \mathrm{Th0} 0_{2}$ (Table 12.2). A fixed charge rate of .2338 is applied to annualize the capital investments over $20 \mathrm{yr}$. 
TABLE 12.2. Bear Lodge Mine Production Costs

North Block

Annual Fixed Charges on Capital Investment

Depreciable Assets

Non-Depreciable Assets

Annual Operating Costs

Annual Production Cost

Depletion

Total Annual Production Cost

Annual Levelized Production of $\mathrm{ThO}_{2}$

Unit cost of Mining
$\$ 8,127,000$ 900,000

$15,822,000$

$\$ 24,849,000$

$-5,467,000$

$\$ 19,382,000$

$2,466,000$

$\$ 7.90 / 1 \mathrm{~b} \mathrm{ThO}_{2}$

Central Block

Annual Fixed Charge on Capital Investment

Depreciable Assets

Non-Depreciable Assets

$\$ 8,127,000$

900,000

Annual Operating Cost

$15,822,000$

Annual Production Cost

$\$ 24,849,000$

Depletion

Total Production Cost

$5,467,000$

Annual Levelized Production of $\mathrm{ThO}_{2}$

$\$ 19,382,000$

Unit cost of Mining

4,502,000

$\$ 4.30 / 1 \mathrm{~b} \mathrm{ThO} \mathrm{TH}_{2}$

South Block

Annual Fixed Charge on Capital Investment

Depreciable Assets

Non-Depreciable Assets

Annual Operating Cost

Annual Production Cost

Depletion

Total Production Cost

Annual Levelized Production of $\mathrm{ThO}_{2}$

Unit cost of Mining
$\$ 8,127,000$

900,000

$15,822,000$

$\$ 24,849,000$

$5,467,000$

$\$ 19,382,000$

$3,752,000$

$\$ 5.20 / 1 \mathrm{~b} \mathrm{ThO} 2$ 


\subsubsection{Mine Capital Costs}

Mine capital costs are estimated from the Palmer, Michigan mine model to be approximately $\$ 43,761,000$. Cost per pit is summarized in Table 12.3.

TABLE 12.3. Mine Capital cost

Mine Buildings and Equipment Cost

$\$ 5,720,000$

Mine Tailings Pond 236,000

Exploration $2,827,000$

Development $25,588,000$

Environmental Impact

Total Depreciable Capital Inves tment 390,000 Land $\$ 34,761,000$

Total Capital Investment $\$ 43,761,000$

\subsubsection{Mine Operating Cost}

Operating costs for the mine are approximately $\$ 15,822,000$ annually (Table 12.4). These costs are assumed from the Palmer, Michigan mine model.

TABLE 12.4. Bear Lodge Mine Operating Costs

Mine Labor Costs

Material and Supplies

Mine Equipment Replacement
$\$ 6,006,000$

$7,770,000$

$2,046,000$

$\$ 15,822,000$

\subsubsection{Mil1 Production Costs}

The milling/refining costs for Bear Lodge are $\$ 48.90 / 1 \mathrm{~b} \mathrm{ThO}_{2}$. A fixed charge of .2338 was applied to nondepreciable capital investment. A charge of $10 \%$ was applied to land and working capital (Table 12.5). 
TABLE 12.5. Bear Lodge Mill Production Costs

Annual Fixed Charge

$\$ 56,133,000$

Annual Operating Cost

$467,712,000$

Subtota 1

$\$ 523,845,000$

Annual $\mathrm{ThO}_{2}$ Production

$10,709,000 \mathrm{lb}$

Unit Cost

$\$ 48.90 / 1 \mathrm{~b} \mathrm{ThO}_{2}$

\subsubsection{Mill Capital Costs}

Mill equipment cost is estimated from both the Conway Granite mill and by scaling up of the Lemhi Pass mill with a .70 scaling factor. Costs are shown below:

$\begin{array}{ll}\text { Conway Granite } & \$ 156,000,000 \\ \text { Lemhi Pass } & \$ 251,000,000\end{array}$

These costs only include mill equipment and facilities.

Since the Conway Granite costs do not include the calcining step, they are assumed to be low. The Lemhi Pass value is assumed to be high because of the substantial economies of scale that would be realized. Thus, an average value of $\$ 200,000,000$ will be assumed. Additional charges include (1) $\$ 100 /$ day/ton for tailings disposal, (2) an additional $\$ 1$ million for environmental impact studies, and (3) a contingency fee. Mill capital cost is thus approximately $\$ 240,000,000$.

\subsubsection{Mi11 Operating Cost}

Mill operating costs are estimated from Conway Granite operating costs and adjusted to reflect a capacity of 90,900 tons per day of ore. Costs are approximately $\$ 467,712,000$ (Table ${ }^{-12.6)}$ ).

\section{Mill Labor Cost}

Mill labor cost is derived from data on the Conway Granite mill. Approximately 87 men $^{(2)}$ are required for acid leaching, solvent extraction and precipitation steps assuming a highly automated processing circuit. An estimated 13 men will also be employed to handle the calcination and packaging operation. 
TABLE 12.6. Bear Lodge Mill Operating Costs

Operating Labor (100 men)

Direct Supervisory and Clerical

Maintenance and Repairs

Utilities

Reagents

Operating Supplies

Laboratory Charges

Plant Overhead

Administrative Overhead

Total
$\$ 2,130,000$

320,000

$2,086,000$

$15,024,000$

$444,117,000$

313,000

320,000

$2,722,000$

680,000

$\$ 467,712,000$

\section{Reagents}

The largest cost consideration in determining reagent expense is the sulfuric acid consumption. Based on data from the U.S.B.M. ${ }^{(3)}$, the process will utilize approximately 450 lb of acid per ton of ore. Consumptions for all other reagents is determined from the thorite milling process ${ }^{(4)}$. Reagent costs are summarized on Table 12.7.

TABLE 12.7. Reagent Consumption and Expense

\begin{tabular}{|c|c|c|c|}
\hline Reagent & $\begin{array}{c}\text { Annual } \\
\text { Consumption }\end{array}$ & Unit Cost & Annual Cost \\
\hline Sulfuric Acid & $6,750,000$ & $\$ 45 /$ ton & $303,750,000$ \\
\hline Lime & $4,185,000$ & $\$ 32 /$ ton & $133,920,000$ \\
\hline $\mathrm{HCl}$ & 15,000 tons & $\$ 61 /$ ton & 915,000 \\
\hline Soda Ash & 18,000 tons & $\$ 69 /$ ton & $1,242,000$ \\
\hline $\mathrm{NaCl}$ & 60,000 tons & $\$ 41 /$ ton & $2,460,000$ \\
\hline $\mathrm{NaSO}_{4}$ & 7,500 tons & $\$ 52 /$ ton & 390,000 \\
\hline \multirow[t]{2}{*}{$\mathrm{N}_{2} \mathrm{OH}$} & 3,000 tons & $\$ .24 / 1 b$ & $1,440,000$ \\
\hline & & & $444,117,000$ \\
\hline
\end{tabular}




\section{$\underline{\text { Utilities }}$}

Utilities consumption is based on data from the Conway Granite refinery. Approximately $10.7 \mathrm{kWh} /$ ton ore will be required at a total cost of $\$ 9,630,000$ annual1y ${ }^{(2)}$. Water consumption is approximately 5 tons/ton ore ${ }^{(4)}$ from the thorite milling process. Cost for water is approximately $\$ 5,394,000$ annually.

\subsubsection{Byproduct Credit}

Since the major rare earth bearing mineral, monazite, is almost inert to dilute sulfuric acid leach, most of the rare earths cannot be recovered using the process outlined in this section.

\subsection{MAJOR UNCERTAINTIES}

Major areas of uncertainty affecting the $\mathrm{ThO}_{2}$ unit cost estimates include mine capital and operating costs, mill capital and operating costs, and thorium recovery efficiency. Our estimate for the ranges of uncertainties in these areas are:

Mine Capital Cost

Mine Operating Cost

Mill Capital Cost

Mill Operating Cost

Thorium Recovery Efficiency

$$
\begin{aligned}
& +50 \% \text { to }-10 \% \text { of calculated value } \\
& +50 \% \text { to }-10 \% \text { of calculated value } \\
& +50 \% \text { to }-10 \% \text { of calculated value } \\
& +60 \% \text { to }-45 \% \text { of calculated value } \\
& 40 \% \text { to } 85 \% \text { wi th a most likely value of } \\
& 60 \%
\end{aligned}
$$

The impact of there uncertainty ranges on the unit cost of $\mathrm{ThO}_{2}$ is shown in Table 12.8. From the incremental unit cost values, a Monte Carlo Statistical analysis is performed using the procedure described in Section 16. From this analysis a most 1 ikely value of $\$ 57.77 / 1 \mathrm{~b} \mathrm{Th0_{2 }}$ and overa11 cost range of $\$ 77.61 / 1 \mathrm{~b} \mathrm{Th0_{2 }}$ to $39.95 / 1 \mathrm{~b} \mathrm{ThO_{2 }}$ is predicted for the unit cost of $\mathrm{ThO}_{2}$ from the north block. Predictions for the central and south blocks are most 1 ikely values of $\$ 56.80 / 1 \mathrm{~b} \mathrm{ThO} \mathrm{O}_{2}$ and $\$ 57.74 / \mathrm{bl} \mathrm{ThO}_{2}$ respectively with ranges of $\$ 87.98 / \mathrm{bl} \mathrm{ThO} \mathrm{T}_{2}$ to $30.96 / 1 \mathrm{~b} \mathrm{ThO} \mathrm{T}_{2}$ and $\$ 89.20 / 1 \mathrm{~b} \mathrm{ThO}_{2}$ to $31.70 / 1 \mathrm{~b} \mathrm{ThO}_{2}$ respectively. 


\section{TABLE 12.8. Uncertainty Ranges for Factors Affecting Bear Lodge Cost Estimates}

\begin{tabular}{|c|c|c|c|c|c|c|}
\hline & & h Block & & al Block & & h Block \\
\hline & $\begin{array}{l}\text { Most Likely } \\
\text { Value } \\
\end{array}$ & Range & $\begin{array}{l}\text { Most Likefy } \\
\text { Value }\end{array}$ & Range & $\begin{array}{l}\text { Most Likely } \\
\text { Value } \\
\end{array}$ & Range \\
\hline Mine Capital Cost $\left(\$ 10^{3} / y r\right)$ & 7,041 & 10,561 to 6,337 & 7,041 & 10,561 to 6,337 & 7,041 & 10,561 to 6,337 \\
\hline Unit Capital Cost $\left(\$ / 1 \mathrm{lb} \mathrm{ThO}_{2}\right)$ & 2.86 & 4.28 to 2.59 & 1.56 & 2.35 to 1.41 & 1.88 & 2.81 to 1.69 \\
\hline Incremental Unit cost $\left(\$ / 1 \mathrm{~b} T \mathrm{Th}_{2}\right)$ & & 1.42 to -.27 & & .79 to -.15 & & .93 to -.19 \\
\hline Mine Operating Cost $\left(\$ / 10^{3} / y r\right)$ & 12,341 & 18,511 to 11,106 & 12,341 & 18,511 to 11,106 & 12,341 & 18,511 to 11,106 \\
\hline Unit Capital Cost $\left(\$ / 1 \mathrm{~b} \mathrm{ThO}_{2}\right)$ & 5.00 & 7.51 to 4.50 & 2.75 & 4.11 to 2.47 & 3.29 & 4.93 to 2.96 \\
\hline Incremental Unit cost $\left(\$ / 1 \mathrm{~b} \mathrm{ThO}_{2}\right)$ & & 2.51 to -.50 & & 1.36 to -.28 & & 1.64 to -.33 \\
\hline Mill Capital Cost $\left(\$ / 10^{3} / y r\right)$ & 56,133 & 84,199 to 50,520 & 56,133 & 84,199 to 50,520 & 56,133 & 84,199 to 50,520 \\
\hline Unit Capital Cost $\left(\$ / 1 \mathrm{~b} \mathrm{ThO}_{2}\right)$ & 5.24 & 7.86 to 4.72 & 5.24 & 7.86 to 4.72 & 5.24 & 7.86 to 4.72 \\
\hline Incremental Unit Cost $\left(\mathrm{S} / 1 \mathrm{~b} \mathrm{ThO}_{2}\right)$ & & 2.62 to -.52 & & 2.62 to -.52 & & 2.62 to -.52 \\
\hline Mill Operating Cost $\left(\$ / 10^{3} / y r\right)$ & 467,712 & 748,399 to 25,692 & 467,712 & 748,339 to 25,692 & 467,712 & 748,339 to 25,692 \\
\hline Unit Capital Cost $\left(\$ / 1 \mathrm{~b} \mathrm{ThO}_{2}\right)$ & 43.67 & 69.87 to 24.02 & 43.67 & 69.87 to 24.02 & 43.67 & 69.87 to 24.02 \\
\hline Incremental Unit Cost $\left(\$ / 1 \mathrm{~b}^{\mathrm{T}} \mathrm{ThO}_{2}\right)$ & & 26.20 to -19.65 & & 26.20 to -19.65 & & 26.20 to -19.65 \\
\hline Thorium Recovery Efficiency $(\%)$ & 60 & 40 to 85 & 60 & 40 to 85 & 60 & 40 to 85 \\
\hline Recovery Efficiency $\cos t\left(\$ / 1 \mathrm{~b} \mathrm{ThO}_{2}\right)$ & 57.80 & 85.62 to 43.57 & 53.20 & 79.82 to 39.89 & 54.10 & 81.15 to 40.57 \\
\hline Incremental Unit cost $\left(\mathrm{S} / 1 \mathrm{lb} \mathrm{ThO}_{2}\right)$ & & 27.82 to -14.23 & & 26.62 to -13.31 & & 27.05 to -13.53 \\
\hline
\end{tabular}




\section{REFERENCES}

1. M. H. Staatz, Proceedings of The Uranium Industry Seminar, 1978, GJ0-108 (78) U.S. Dept. of Energy, Grand Junction, C0. pp. 109-115, 1978.

2. F. J. Hurst, et al., Estimated Costs for Recovery of Thorium and Uranium, ORNL-3988, Oak Ridge National Laboratory, Oak Ridge, TN, November 1966.

3. Jim F. Lemons, Jr. and Luis V. Coppa, Mining and Processing Methods and Cost Models for the Recovery of Thorium from Domestic Occurrences, GJBX-91(79), U.S. Dept. of Energy, Grand Junction, C0, pp. 14-17.

4. S. R. Borrowman and J. B. Rosenbaum, Recovery of Thorium from Ores in Colorado, Idaho, and Montana, USBM 5916, United States Bureau of Mines, Update 1976, 16 pp. 


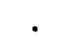




\subsection{THORIUM PRODUCTION FROM BALD MOUNTAIN, WYOMING}

\subsection{RESOURCE DESCRIPTION}

Bald Mountain is located approximately 6 miles north of Sundance, Wyoming in the Bear Lodge Mountain area. With an elevation of 4,802 ft, the Bald Mountain deposit is entirely located in the Black Hills National Forest and is characterized by fairly steep hills and gullies with $800 \mathrm{ft}$ to 1,000 ft relief. The deposit consists of a central core of precambrian granite with syenite porphyries of a tertiary age ${ }^{(1)}$. Microscopic examination of $1,400 \mathrm{lb}$ of drill core from Bald Mountain showed the principal constituents are quartz and feldspars with lessor concentrations of garnet, hematite, limonite, magnetite, ilmenite, zircon, and monazite ${ }^{(2)}$. The monazite in 20 million tons of material is reported to average $2.5 \mathrm{lb} /$ ton of ore. A small but high grade stratum continues 675,000 tons averaging 13.2 lb of monazite per ton ${ }^{(3)}$. For purposes of this study, however, the monazite is assumed to be evenly distributed throughout the rock. The average grade of the monazite is reported to be $8.8 \% \mathrm{ThO}_{2}{ }^{(2)}$. The average ore grade of the Bald Mountain deposit is assumed to be $0.013 \%$ or approximately $2.851 \mathrm{~b}$ of monazite per ton of ore.

Bald Mountain contains approximately 2,600 tons of $\mathrm{ThO}_{2}$. Other byproducts include as much as $7,700,000$ tons of ilmenite and 16,000 tons of rare earth oxides $(4)$.

\subsection{MINE DESCRIPTION}

Currently, Bald Mountain is not being mined for thorium. The conceptual Bald Mountain mine is based on the Palmer, Michigan mine assuming a similar deposit geometry. The conceptual mine shall produce approximately $10,000 \mathrm{tpd}$ of ore assuming a mine 1 ife of $10 \mathrm{yr}$. The mine is designed to operate 3 shifts/day, five days/week for 240 day/yr.

\subsubsection{Mining Process}

The mining process is the same for Bald Mountain mine as the Palmer, Michigan mine. The conceptual mining process is described in Section 11.2.1 of this report. 


\subsection{MILL DESCRIPTION}

No commercial scale conglomerate benefication facilities currently exist; however, laboratory work indicates Bald Mountain monazite can be concentrated with $61 \%$ recovery ${ }^{(2)}$.

A reference facility, based on this laboratory work, was designed to concentrate the output from a conceptual Bald Mountain mine. The mill has a capacity of 6,860 tpd of ore and produces 14 tons of concentrate. The concentrate contains $5.7 \% \mathrm{ThO}_{2}$ and $40.4 \%$ rare earth oxides. The mill is designed to operate three shifts per day, seven days per week, for 350 days per year. The mill is described in Section 11.3 of this report.

\subsection{REF INERY DESCRIPTION}

Monazite from Bald Mountain is shipped to a refining facility. The reference conglomerate refinery is described in Section 11.4 of this report.

\subsection{BALD MOUNTAIN PRODUCTION COSTS}

The production costs for developing an estimated 1,500 tons of $\mathrm{ThO}_{2}$ from Bald Mountain is $\$ 45.70 / 1 \mathrm{~b} \mathrm{ThO}_{2}$ (Table 13.1). After taking into account uncertainties in mine/mill capital and operating costs, refinery capital and operating costs, thorium recovery, plant capacity, and refinery location, a unit cost of $\$ 49.00 / 1 \mathrm{~b} \mathrm{Th0_{2 }}$ is estimated from the method described in Section 10. These costs are developed in the following sections.

TABLE 13.1. Bald Mounta in Production Cost Summary

$$
\text { Unit Cost }\left(\$ / 1 \mathrm{~b} \mathrm{ThO}_{2}\right)
$$

Mining/Milling $\$ 42.50$

Refining 3.19

Total from Estimates $\$ 45.70$

Total Including Uncertainty $\$ 49.00$ 


\subsubsection{Mine/Mill Production Cost}

The production costs for operating the Hall Mountain mine are shown in Table 13.2. A fixed charge rate of .2668 is applied to the capital investment.

\section{TABLE 13.2. Bald Mountain Mine/Mill Production Costs}

Annuar Fixed Charges:

Depreciable Capital

$\$ 16,735,000$

Non-Depreciable Capital

728,000

Annual Operating Costs

$15,335,000$

Subtotal

$32,798,000$

Depletion Allowance

$7,216,000$

Annual Production Costs

$25,582,000$

Annual Levelized Production of $\mathrm{ThO}_{2}$

602,000

Unit Cost of Mining/Milling

$\$ 42.50 / 1 \mathrm{~b} \mathrm{ThO}$

\subsubsection{Mine/Mill Capital Costs}

Capital costs are calculated by scaling down the Palmer, Michigan cost estimate with a .75 scaling factor (Section 6.8). Capital costs for Bald Mountain are approximately $\$ 70,000,000$. These costs are summarized in Table 13.3.

TABLE 13.3. Bald Mountain Mine/Mill Capital Costs

Depreciable Capital Inves tment

$\$ 62,724,000$

Land and Working Capital

$7,276,000$

TOTAL Capital Investment

$\$ 70,000,000$

\subsubsection{Mine/Mill Operating Costs}

Operating costs for Bald Mountain are also scaled down from Palmer using .75 scaling factor. Annual operating costs for Bald Mountain are estimated at $\$ 15,335,000$. 


\subsubsection{Refinery Production Costs}

The summary of refinery production costs are shown in Table 13.4. Bald Mountain ore constitutes only $8.6 \%$ of the total ore refined at the Palmer, Michigan refinery. For calculational purposes, capital and operating costs are scaled down linearly from the Palmer, Michigan costs to reflect the portion of the refinery with only Bald Mountain ore as input.

\section{TABLE 13.4. Bald Mountain Refinery Production Costs}

Fixed Charges:

Depreciable Capital

$\$ 337,000$

Nondepreciable Capital

19,000

Annual Operating Costs

729,000

Subtotal

$\$ 1,085,000$

Annual Transportation Cost

833,000

Annual Production cost

$\$ 1,918,000$

Annual Levelized $\mathrm{ThO}_{2}$ Production

602,000

Unit cost of Refining

\subsubsection{Transportation Cost}

Transportation of thorium ore from the Bald Mountain area to Palmer would be provided by rail. Rail rates are estimated at $\$ 8.50 / \mathrm{cwt}$. Annual transportation charges are estimated at $\$ 833,000$.

\subsubsection{Major Uncertainties}

Major areas of uncertainty affecting the $\mathrm{ThO}_{2}$ unit cost estimates include mine/mill capital and operating costs, refinery capital and operating costs, plant capacity, refinery location, and thorium recovery efficiency. Our estimates for the range of uncertainties in these areas are:

Mine/Mill Capital Cost

Mine/Mil1 Operating Cost

Refinery Capital Cost

Refinery Operating Cost

Plant Capacity
$+50 \%$ to $-10 \%$ of calculated value $+50 \%$ to $-50 \%$ of calculated value $+50 \%$ to $-10 \%$ of calculated value $+50 \%$ to $-10 \%$ of calculated value from 5,000 to 20,000 tpd, with most likely value of 10,000 tpd 
Refinery Location

Thorium Recovery Efficiency onsite or at Paimer, Michigan, most 1ikely at Paimer

from $42 \%$ to $82 \%$, with a most iikety value of $58 \%$

The impact of these uncertainty ranges on the unit cost of $\mathrm{ThO}_{2}$ is shown in Table 13.5. From the incremental unit cost values, a Monte Carlo statistical analysis is performed using the procedure described in Section 16. From this analysis, a most likely value of $\$ 49 / 1 \mathrm{~b} \mathrm{ThO}_{2}$ and overall cost range of $\$ 29 / 1 \mathrm{~b} \mathrm{ThO}_{2}$ to $\$ 68 / 1 \mathrm{~b} \mathrm{ThO}_{2}$ is predicted for the unit cost of $\mathrm{ThO}_{2}$.

TABLE 13.5. Uncertainty Ranges for Factors Affecting $\mathrm{ThO}_{2}$ Unit Cost

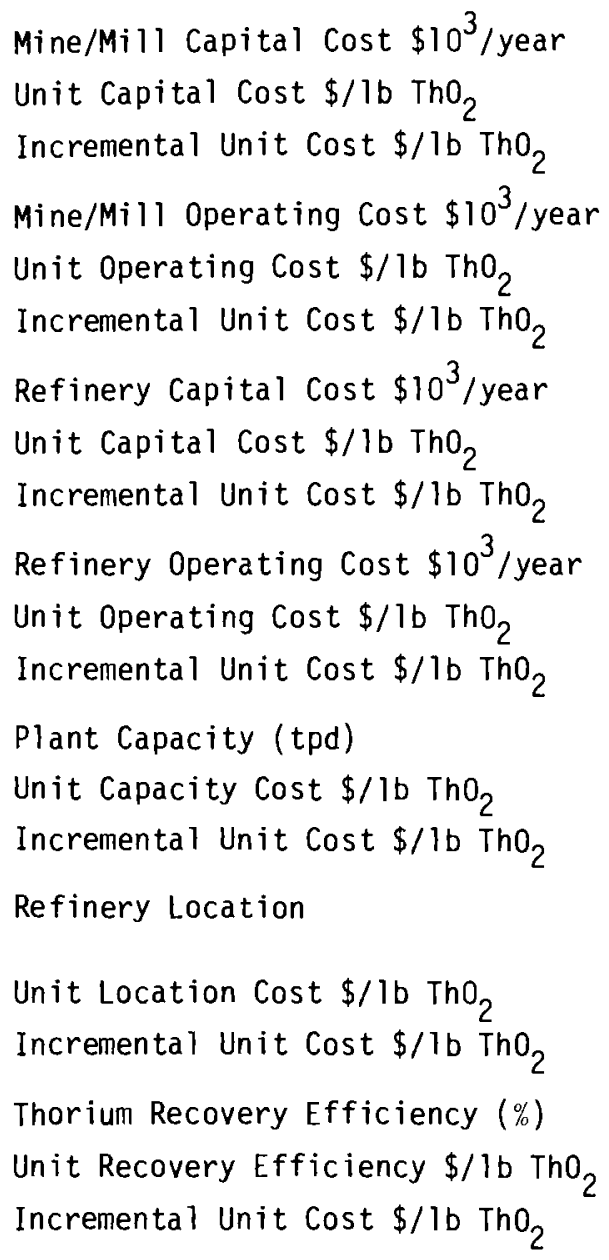

\begin{tabular}{r} 
Range \\
\hline 20,432 to 12,259 \\
33.94 to 20.36 \\
+11.31 to -2.27 \\
17,942 to 5,981 \\
29.80 to 9.93 \\
+9.93 to -9.94 \\
534 to 320 \\
.89 to .53 \\
+.30 to -.06 \\
1.094 to 656 \\
1.82 to 1.09 \\
+.61 to -.12 \\
5,000 to 20,000 \\
51.87 to 40.35 \\
+6.18 to -5.34 \\
Palmer, Michigan \\
or ons $i$ te \\
47.02 to 45.69 \\
+1.33 to 0 \\
42 to 82 \\
63.10 to 32.32 \\
+17.41 to -13.37
\end{tabular}

(a) Depletion allowance $(22 \%)$ is subtracted from cost 



\section{REFERENCES}

1. J. C. 01 son, and W. C. Overstreet, Geologic Distribution and Resources of Thorium. U.S. Geological Survey Bulletin 1204, 1964.

2. S. R. Borrowman, and J. B. Rosenbaum, Recovery of Thorium from a Wyoming Ore. U.S. Bureau of Mines Report Inv. 5917, 1962.

3. V. R. Wilrath, and D. H. Johnson, Preliminary Reconnaissance Survey for Thorium, Uranium, and Rare-Earth Oxides, Bear Lodge Mountains, Crook County, Wyoming. Trace Elements Investigations Report 172, U.S. Geol. Survey, 26 pp., April 1953.

4. R.H. Perry and C.H. Chilton, Chemical Engineers' Handbook, 5th Ec., McGraw-Hil1 Book Company, New York, N.Y., pp.25-16 and 25-17, 1973. 


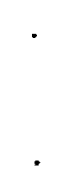




\subsection{THORIUM PRODUCTION FROM CONWAY GRANITE}

A study was conducted by the Atomic Energy Commission (AEC) in 1966 to determine the economics of obtaining thorium from Conway granite. This discussion is based on the AEC report $(1,2)$, but the costs have been updated to 1978.

\subsection{RESOURCE DESCRIPTION}

Conway granite of New Hampshire is a large potential source of $\mathrm{ThO}_{2}$. The deposit, occupying approximately 307 square miles in the White Mountains contains an estimated 35 million tons of thorium and extends to a depth of at least $1000 \mathrm{ft}$. Thorium is distributed evenly in the outcrop with an average grade of $56 \pm 6 \mathrm{ppm}(0.006 \%) \mathrm{ThO}_{2}(1,2)$.

Typical Conway granite consists primarily of quartz, perthite, minor biotite, and plagioclase minerals. It is coarse-grained, pink, and massive al though some outcrops are greenish and locally fine-grained. Uranium is associated with the thorium. Uranium content is at least one-fourth the thorium content.

\subsection{MINE DESCRIPTION}

Granite is mined by open pit methods. Mine production is assumed to be 100,000 tons/day of ore and approximately 20,000 tons/day of waste. The mine operates 3 shifts a day, 350 days/year for 20 years. Ore recovery is assumed to be $100 \%$.

\subsubsection{Mining Process}

The mining process is assumed to be similar to the open pit methods utilized at Palmer, Michigan (see Section 11.2.1). The Conway mining process utilizes standard drills of the "down the hole" type to make blast holes. Shovels $\left(8 \mathrm{yd}^{3}\right)$ load the ore and waste into electric wheel trucks. The ore is carried to the mill. The waste is hauled by electric train to a disposal area. 


\subsection{MILL DESCRIPTION}

Granite is not currently processed for thorium in the United States. However, laboratory studies on the benefication of thorium and uranium from granite reveal that direct leaching of the ore with dilute sulfuric acid yields the best results. The reference granite mill is assumed to process 100,000 tpd of ore and produce 7,200 $\mathrm{lb}$ of $\mathrm{ThO}_{2}$ in the form of 6.3 tpd of concentrate assuming a thorium recovery of $60 \%$. This concentrate contains $57 \%$ $\mathrm{ThO}_{2}$ and $16.7 \%$ uranium. The mill operates 3 shifts/day, 350 days/year for $20 \mathrm{yr}$.

\subsubsection{Milling Process}

The milling circuit consists of acid leaching followed by amine extraction and ammonia precipitation. The milling process is summarized in the following sections. A process flow diagram is shown in Figure 14.1.

\subsubsection{Crushing and Grinding}

The mined ore is crushed to $8 \mathrm{in}$. in large gyratory crushers. The crushed ore is transported to an outside stockpile holding about an $8 \mathrm{hr}$ supply of granite. The ore is then fed to dry, autogenous mills of the aerofall type for grinding to minus 20 mesh.

\subsubsection{Acid Leaching}

The ground ore is then agglomerated in rotating drums with 20-60 ib of sulfuric acid per ton of ore to produce a mix containing $85 \%$ solids. The agglomerated ore is then conveyed to concrete vats and cured for 1 to 5 hours. Recycle process solutions are utilized to wash the ore in the vats to obtain a thorium and uranium solution. The relatively small, high acid portion of the wash solution obtained first is recycled to the agglomeration operation. The next portion of the wash cycle constitutes the pregnant liquor and goes to the solvent extraction step. The latter portion of the wash solution with a much lower concentration of thorium and uranium is recycled for washing subsequent batches of ore. A final flush solution containing ore tailings and water goes to lime neutralization and waste. 


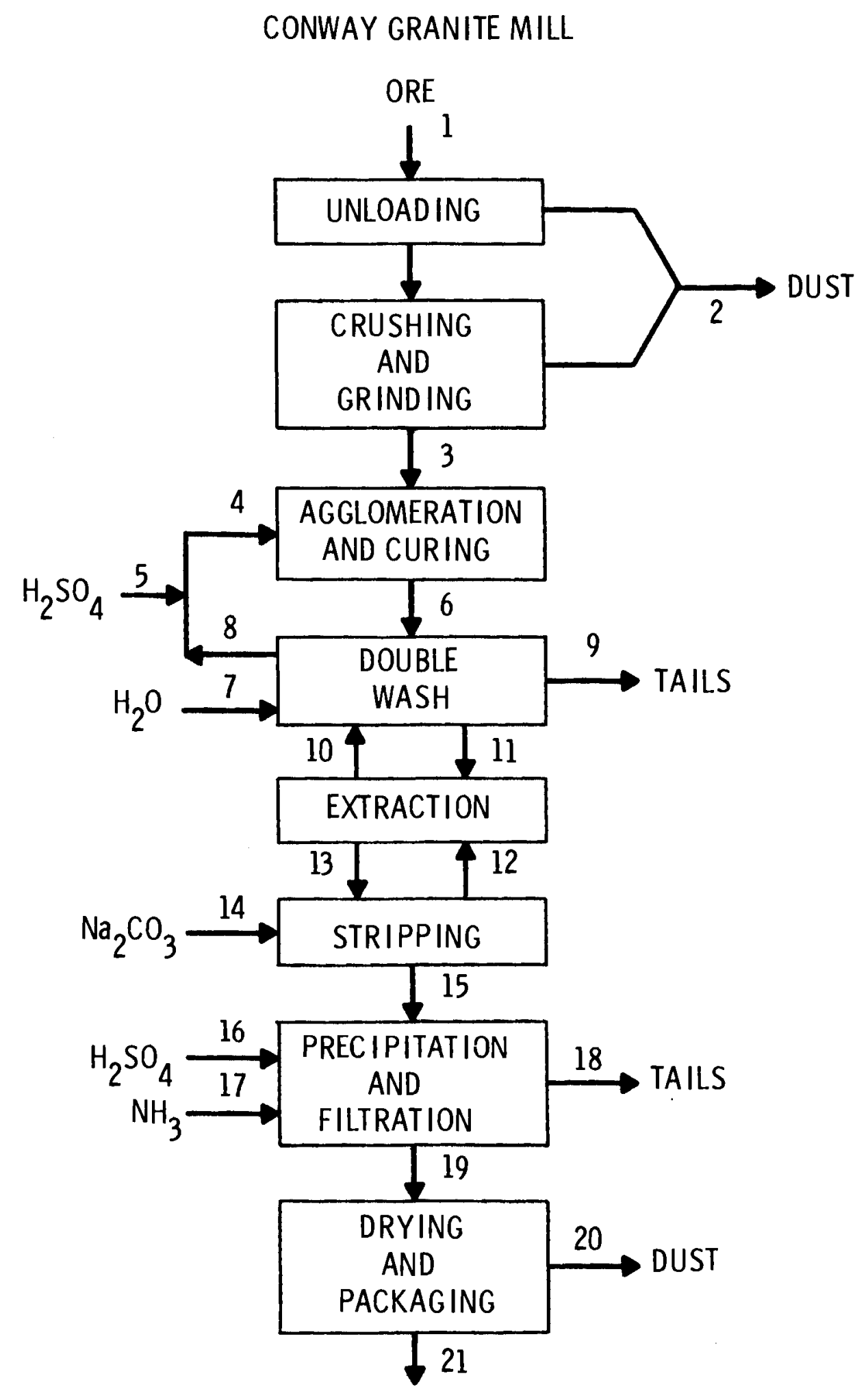

FIGURE 14.1. Conway Granite Refinery 


\section{FLOW STREAMS FOR CONWAY GRANITE MILL}

1. 4545.45 tons $/ \mathrm{hr}$ ore $\mathrm{w} /{ }^{232} \mathrm{Th}=480 \mathrm{lb} / \mathrm{hr}$

2. $454.5 \mathrm{lb} / \mathrm{hr} \mathrm{w} /{ }^{232} \mathrm{Th}=2.4024 \times 10^{-3} \mathrm{lb} / \mathrm{hr}$

3. 4545.22 tons $/ \mathrm{hr} \mathrm{w} /{ }^{232} \mathrm{Th}=480 \mathrm{lb} / \mathrm{hr}$

4. 800 tons $/ \mathrm{hr}$

5. 72.72 tons $/ \mathrm{hr} \mathrm{H}_{2} \mathrm{SO}_{4}$

6. 5345.22 tons $/ \mathrm{hr} \mathrm{w} /{ }^{232} \mathrm{Th}=480 \mathrm{lb} / \mathrm{hr}$

7. 1181.7 tons $/ \mathrm{hr} \mathrm{H} \mathrm{H}_{2} \mathrm{O}$

8. 727.28 tons $/ \mathrm{hr}$

9. 5799.46 tons $/ \mathrm{hr} \mathrm{w} /{ }^{232} \mathrm{Th}=167.96 \mathrm{lb} / \mathrm{hr}$

10. 2908.8 tons $/ \mathrm{hr}$

11. 2908.98 tons $/ \mathrm{hr} w /{ }^{232} \mathrm{Th}=312.04 \mathrm{ib} / \mathrm{hr}$

12. 500 tons $/ \mathrm{hr}$ amine solvent

13. 500.18 tons $/ \mathrm{hr} w /{ }^{232} \mathrm{Th}=312.04 \mathrm{lb} / \mathrm{hr}$

14. 63.63 tons $/ \mathrm{hr} \mathrm{Na} \mathrm{CO}_{3}$

15. 63.81 tons $/ \mathrm{hr} w / 232 \mathrm{Th}=312.04 \mathrm{lb} / \mathrm{hr}$

16. 2.73 tons $/ \mathrm{hr} \mathrm{H}_{2} \mathrm{SO}_{4}$

17. $909 \mathrm{ib} / \mathrm{hr} \mathrm{NH}$

18. 66.71 tons $/ \mathrm{hr} \mathrm{w} /{ }^{232} \mathrm{Th}=23.999 \mathrm{ib} / \mathrm{hr}$

19. $574.24 \mathrm{lb} / \mathrm{hr} w /{ }^{232} \mathrm{Th}=288.04 \mathrm{lb} / \mathrm{hr}$

20. $0.029 \mathrm{lb} / \mathrm{hr} w /{ }^{232} \mathrm{Th}=1.452 \times 10^{-2} \mathrm{lb} / \mathrm{hr}$

21. $574.21 \mathrm{lb} / \mathrm{hr} \mathrm{w} /{ }^{232} \mathrm{Th}=288.024 \mathrm{lb} / \mathrm{hr}$

FIGURE 14.1. (cont'd)

\subsubsection{Solvent Extraction}

The pregnant liquor goes to a two-stage solvent extraction section. The solvent consists of .01 M 1-nondecylamine and .01 M N-benzyl-1-(3 ethylpenty 1)-4-ethylocty 1 amine in $99 \%$ kerosene- $1 \%$ tridecanol diluent. Thorium and uranium are then costripped from the extract with $.25 \mathrm{M} \mathrm{Na}_{2} \mathrm{CO}_{3}$ solution in two stages. Standard mixer-settler equipment performs the extraction and stripping operations. 


\subsubsection{Packaging}

The thorium-uranium precipitate is filtered, dried, and stored for further refinement and separation.

\subsection{REFINERY DESCRIPTION}

The reference granite refinery shall be similar to the reference stockpile refinery except for the addition of a extraction cascade which precedes the $\mathrm{ThO}_{2}$ extraction steps (see Figure 14.2). The cascade shall utilize 10 stages and a 5\% TBP solvent to remove uranium from the thorium solution. The refining process is described in Section 7.2 of this report. The uranium recovery steps shall be discussed below.

\subsubsection{Uranium Recovery}

The thorium-uranium solution enters a 5 stage solvent extraction section where the aqueous is contacted with a 5\% solution of TBP in kerosene. The thorium-bearing aqueous continues on to the next solvent extration section. The organic solution enters a 5-stage scrub section where the uranium is removed from the solvent using a $4 \mathrm{~N}$ nitric acid solution. The uranium solution is precipitated with ammonia, dewatered, and dried. The stripped solvent is recycled.

\subsection{CONWAY GRANITE PRODUCTION COST}

The production costs for developing $\mathrm{ThO}_{2}$ from Conway granite are summarized in Table 14.1. After accounting for uncertainties in mine, mill, and refinery capital and operating costs, byproduct credit, plant capacity, and thorium recovery efficiency, a most likely cost of $\$ 59.30 / 1 \mathrm{~b} \mathrm{ThO}_{2}$ was determined by the method described in Section 16. These costs are developed in the following sections.

\subsubsection{Mine/Mil1 Production Costs}

The production costs for operating the Conway granite mine and mill are shown in Table 14.2. A fixed charge of .2330 was applied to annualize nondepreciable capital investment over $30 \mathrm{yr}$. 


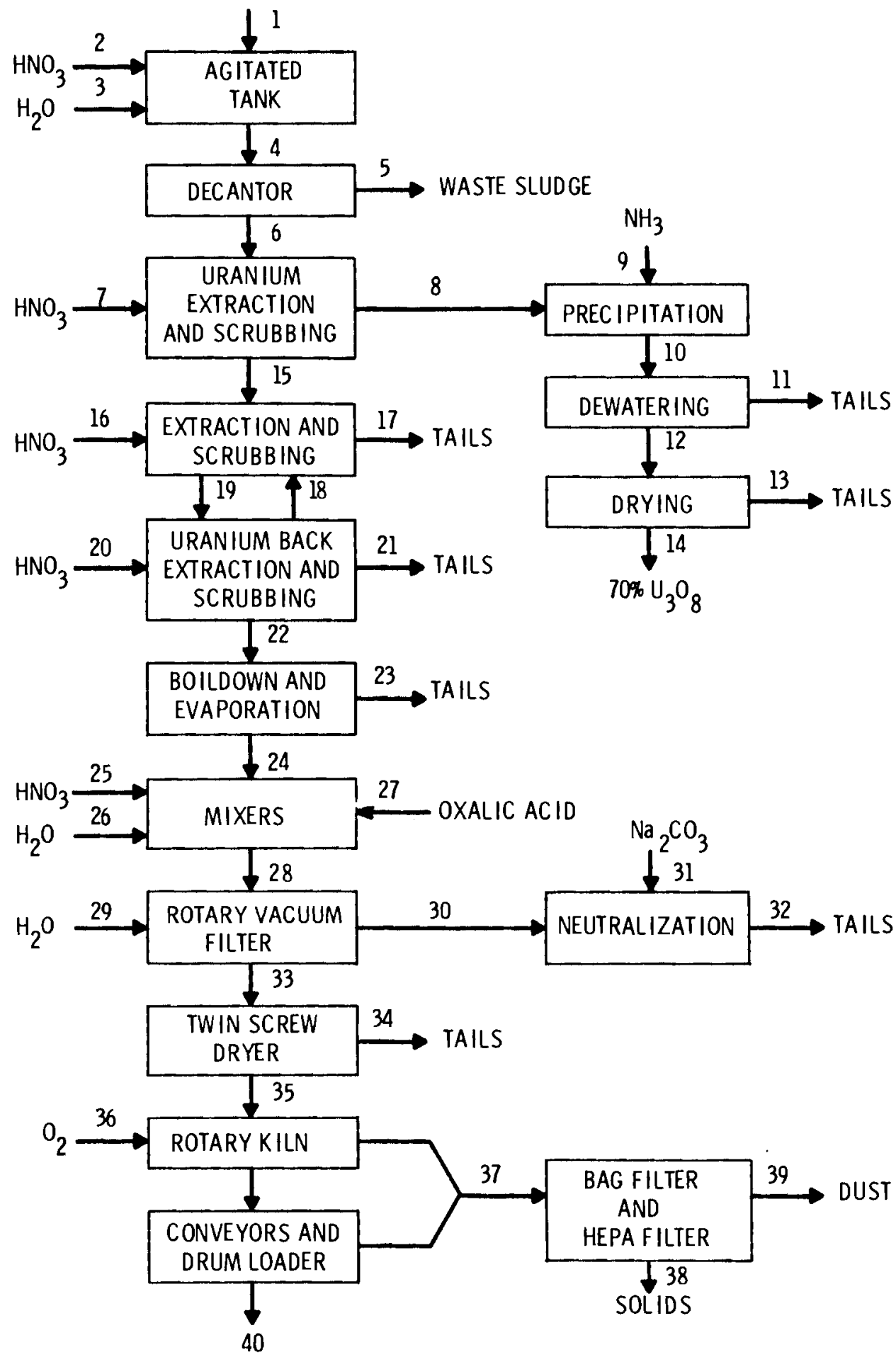

FIGURE 14.2. Conway Granite Refinery 
1. $570 \mathrm{lb} / \mathrm{hr} \mathrm{w} /{ }^{232} \mathrm{Th}=285.91 \mathrm{~b} / \mathrm{hr}$

2. $299 \mathrm{lb} / \mathrm{hr} \mathrm{HNO}_{3}$

3. $491 \mathrm{lb} / \mathrm{hr} \mathrm{H} \mathrm{H}_{2} \mathrm{O}$

4. $1360 \mathrm{lb} / \mathrm{hr} \mathrm{w} /{ }^{232} \mathrm{Th}=285.9 \mathrm{lb} / \mathrm{hr}$

5. $663 \mathrm{lb} / \mathrm{hr} w /{ }^{232} \mathrm{Th}=5.72 \mathrm{lb} / \mathrm{hr}$

6. $697 \mathrm{lb} / \mathrm{hr} \mathrm{w} /{ }^{232} \mathrm{Th}=280.18 \mathrm{lb} / \mathrm{hr}$

7. $1367 \mathrm{lb} / \mathrm{hr} 4 \mathrm{M} \mathrm{HNO}$

8. $1367 \mathrm{lb} / \mathrm{hr} \mathrm{w} /{ }^{232} \mathrm{Th}=.308 \mathrm{lb} / \mathrm{hr}$

9. $33 \mathrm{lb} / \mathrm{hr} \mathrm{NH}$

10. $1400 \mathrm{lb} / \mathrm{hr} \mathrm{w} /{ }^{232} \mathrm{Th}=.308 \mathrm{lb} / \mathrm{hr}$

11. $1216 \mathrm{lb} / \mathrm{hr} w /{ }^{232} \mathrm{Th}=.308 \mathrm{lb} / \mathrm{hr}$

12. $184 \mathrm{lb} / \mathrm{hr}$

13. $56.86 \mathrm{lb} / \mathrm{hr} \mathrm{H} \mathrm{H}_{2} \mathrm{O}$

14. $127.14 \mathrm{lb} / \mathrm{hr}\left(70 \% \quad \mathrm{U}_{3} \mathrm{O}_{8}\right)$

15. $697 \mathrm{lb} / \mathrm{hr} \mathrm{w} /{ }^{232} \mathrm{Th}=279.87 \mathrm{lb} / \mathrm{hr}$

16. $557 \mathrm{lb} / \mathrm{hr} \mathrm{HNO}_{3}$

17. $1254 \mathrm{lb} / \mathrm{hr} \mathrm{w} / /^{232} \mathrm{Th}=.264 \mathrm{lb} / \mathrm{hr}$

18. $6359 \mathrm{lb} / \mathrm{hr}$

19. $6677 \mathrm{lb} / \mathrm{hr} w /{ }^{232} \mathrm{Th}=279.606 \mathrm{lb} / \mathrm{hr}$

20. $6677 \mathrm{lb} / \mathrm{hr}$ of $.1 \mathrm{~N} \mathrm{HNO}_{3}$

21. $318 \mathrm{lb} / \mathrm{hr}$

22. $6677 \mathrm{lb} / \mathrm{hr} \mathrm{w} /{ }^{232} \mathrm{Th}=279.606 \mathrm{lb} / \mathrm{hr}$

23. $5351 \mathrm{lb} / \mathrm{hr} \mathrm{H}_{2} \mathrm{O}$

24. $1326 \mathrm{lb} / \mathrm{hr} \mathrm{w} /{ }^{232} \mathrm{Th}=279.606 \mathrm{lb} / \mathrm{hr}$

25. $7,4 \mathrm{lb} / \mathrm{hr} \mathrm{HNO}_{3}$

26. $87 \mathrm{lb} / \mathrm{hr} \mathrm{H} \mathrm{H}_{2}$

27. $112.6 \mathrm{lb} / \mathrm{hr}$ oxalic acid

28. $1599.6 \mathrm{lb} / \mathrm{hr} \mathrm{w} /{ }^{232} \mathrm{Th}=279.606 \mathrm{lb} / \mathrm{hr}$

29. $288.9 \mathrm{lb} / \mathrm{hr} \mathrm{H}_{2} \mathrm{O}$

30. $1070.9 \mathrm{lb} / \mathrm{hr} \mathrm{w} /{ }^{232} \mathrm{Th}=2.29 \mathrm{lb} / \mathrm{hr}$

31. $309.7 \mathrm{lb} / \mathrm{hr} \mathrm{Na}{ }_{2} \mathrm{CO}_{j}$

32. $1380.6 \mathrm{lb} / \mathrm{hr} \mathrm{w} /{ }^{232} \mathrm{Th}=2.29 \mathrm{lb} / \mathrm{hr}$

33. $817.6 \mathrm{lb} / \mathrm{hr} \mathrm{w} /{ }^{232} \mathrm{Th}=277.316 \mathrm{lb} / \mathrm{hr}$

34. $326 \mathrm{lb} / \mathrm{hr} \mathrm{H} \mathrm{O}$

35. $581.6 \mathrm{lb} / \mathrm{hr} \mathrm{w} /{ }^{232} \mathrm{Th}=277.316 \mathrm{lb} / \mathrm{hr}$

36. $43.3 \mathrm{lb} / \mathrm{hr} \mathrm{O}_{2}$

37. $100.8 \mathrm{lb} / \mathrm{hr} \mathrm{H} \mathrm{H}_{2} \mathrm{O}$ and $205.8 \mathrm{lb} / \mathrm{hr} \mathrm{CO}_{2} \mathrm{w} /{ }^{232} \mathrm{Th}=5.72 \mathrm{lb} / \mathrm{hr}$

38. $5.66 \mathrm{lb} / \mathrm{hr} 232 \mathrm{Th}$

39. $307.7 \mathrm{lb} / \mathrm{hr} \mathrm{w} /{ }^{232} \mathrm{Th}=5.72 \times 10^{-2} \mathrm{lb} / \mathrm{hr}$

40. $311.8 \mathrm{lb} / \mathrm{hr} \mathrm{w} /{ }^{232} \mathrm{Th}=271.60$

FIGURE 14.2. (cont'd) 
TABLE 14.1. Conway Granite Production Costs

$\begin{array}{lc} & \text { Unit Cost } \$ / 1 \mathrm{~b} \\ \text { Mining/Milling } & \$ 58.70 \\ \text { Refining } & \frac{3.30}{\$ 62.00} \\ \text { Total Product Cost (No Byproducts) } & \frac{11.70}{\text { Uranium Byproduct Credit }} \\ \text { Total Product Cost (Full Byproducts) } & \$ 50.20 \\ \text { Total (Including Uncertainty) } & \$ 59.30\end{array}$

TABLE 14.2. Conway Granite Mine/Mil1 Production Costs

Annual Fixed Charges:

Depreciable Capital

$\$ 73,683,000$

Nondepreciable Capital

$3,347,000$

Annual Operating Costs (Mine)

$44,940,000$

Annual Operating Costs (Mill)

$91,922,000$

Annual Production Costs

$\$ 213,892,000$

Depletion Allowance

$-47,056,000$

Annual Production Cost

$\$ 166,836,000$

Average Levelized Production of $\mathrm{ThO}_{2}$

$2,842,700 \mathrm{lb}$

Unit Cost of Mining and Milling

$\$ 58.70 / 1 \mathrm{~b} \mathrm{ThO}_{2}$

\subsubsection{Mine/Mill Capital Costs}

Capital costs were estimated for the mine and mill in two ways: (1) by escalation of the AEC study and (2) by scaling up of Palmer, Michigan mine/ mill capital costs. The costs for Palmer, Michigan do not include a solvent extraction facility. However, land costs are probably higher than necessary because of purchasing the town of Palmer. These costs are shown in Table 14.3. An average cost of $\$ 348,622,000$ is used in this study.

\subsubsection{Mine/Mill Operating Costs}

Mine operating costs are estimated from the Palmer, Michigan, study to be $\$ 1.07 /$ ton of ore or approximately $\$ 44,940,000$ annually. 
TABLE 14.3. Conway Granite Mine/Mi11 Capital Cost

\begin{tabular}{|c|c|c|}
\hline & AEC & Palmer \\
\hline Total Depreciable Capital Investment & $\$ 284,466,000$ & $\$ 345,840,000$ \\
\hline Working Capital & $26,823,000$ & $40,115,000$ \\
\hline Total Capital Investment & $\$ 311,289,000$ & $\$ 385,955,000$ \\
\hline
\end{tabular}

Mill operating costs were determined assuming labor, reagent and utility requirements from the AEC study. Other costs were determined using the procedure outlined in Section 6.0.

Mil1 operating costs are approximately $\$ 91,922,000$ annually (Table 14.4). Reagent and utility requirements were derived from the AEC study and are shown in Tables 14.5 and 14.6.

\subsubsection{Refinery Production Costs}

The unit cost of refining is estimated from the sludge refining data in Table 7.1 by assuming the concentrate contains $57 \% \mathrm{ThO}_{2}$. By interpolating between costs for processing $46 \%$ and $88 \% \mathrm{ThO}_{2}$, the refining cost for Conway granite is $\$ 3.01$.

TABLE 14.4. Mill Operating Costs

Operating Labor (87 men)

Direct Supervisory and Clerical

Maintenance and Repairs

Utilities

Reagents

Operating Supplies

Laboratory Charges

Plant Overhead

Administrative Overhead
$\$ 5,890,000$

884,000

$10,000,000$

$11,750,000$

$57,422,000$

$1,500,000$

900,000

$10,060,000$

$\underline{2,516,000}$ 
TABLE 14.5. Reagent Consumption and Expense

\begin{tabular}{lcccr}
\multicolumn{1}{c}{ Reagent } & Annual Consumption & & Unit Cost & Annual Cost \\
\cline { 5 - 6 } Sulfuric Acid & 700,000 tons & & $\$ 55 /$ ton & $\$ 38,500,000$ \\
Lime & 434,000 tons & & $37 /$ ton & $16,058,000$ \\
Soda Ash & 13,125 tons & $68.9 /$ ton & 904,000 \\
Ammonia & 3,500 tons & $120 /$ ton & 420,000 \\
Amine Solvents & 420,000 lbs & $1 /$ ton & 420,000 \\
Total Solvents & $2,800,000$ gal & 0.4 gal & $1,120,000$ \\
& & & & $\$ 57,422,000$
\end{tabular}

TABLE 14.6. Utilities

Electricity $(10.7 \mathrm{kWh} /$ ton of ore)

$\$ 11,235,000$

Water $\quad(12,500 \mathrm{gpm})$

312,000

Fuel 0 il $(0.008 /$ ton of ore $)$

280,000

$\$ 11,830,000$

\subsubsection{Byproduct Credit}

Byproduct credit is calculated assuming $\$ 40 / 1 \mathrm{~b}$ contained $\mathrm{U}_{3} \mathrm{O}_{8}$. Assuming a $\mathrm{U}_{3} \mathrm{O}_{8}$ production of $771,540 \mathrm{lb} / \mathrm{yr}$ for a $600 \mathrm{lb}$ refinery, byproduct revenue is approximately $\$ 30,861,600$ annually. After subtracting the incremental uranium production costs, full byproduct credit is estimated at $\$ 29,403,000$ annually. This is approximately $\$ 11.70 / 1 \mathrm{~b} \mathrm{ThO}_{2}$.

\subsubsection{Byproduct Capital Cost}

The estimated additional capital cost associated with recovering uranium is summarized in Table 14.7. This cost is approximately $\$ 7,074,000$.

\subsubsection{Byproduct Operating Cost}

The additional operating costs for byproduct recovery are summarized in Table 14.8. Labor costs are based on the number of operators necessary to equipment operation. Supervision, maintenance and repairs, operating supplies, laboratory charges, utilities, and indirect costs are estimated using the procedure described in Section 6.0. Reagent expense is itemized in Table 14.9. 
TABLE 14.7. Conway Granite Byproduct Capital Cost

Byproduct Buildings \& Equipment Cost

$\$ 745,000$

Contingency ( $15 \%$ of DPC)

108,000

Feasibility Study

100,000

Total Depreciable Capital Investment

953,000

Land

3,000

Working Capital

108,200

$\$ 1,074,000$

TABLE 14.8. Conway Granite Byproduct Operating Cost

Direct Costs

Operating Labor ( 5 men/shift)

$\$ 339,000$

Supervision

51,000

Maintenance Repairs

64,000

Operating Supplies

10,000

Utilities ( $5 \%$ of direct costs) (3)

44,000

Laboratory Charges

51,000

Reagents

325,000

Indirect costs

Plant Overhead

$\$ 272,000$

Administrative Overhead

68,000

$\$ 1,224,000$

TABLE 14.9. Reagent Consumption and Expense

\begin{tabular}{|c|c|c|c|}
\hline Reagent & Annual Consumption & Unit Cost & Annual Cost \\
\hline $\mathrm{HNO}_{3}$ & 1,400 tons & $\$ 10.50 / 1001 \mathrm{~b}$ & $\$ 294,000$ \\
\hline $\mathrm{NH}_{3}$ & 150 tons & $120.00 /$ ton & 18,000 \\
\hline TBP & $8,0001 \mathrm{~b}$ & $0.88 / 1 b$ & 7,000 \\
\hline \multirow[t]{2}{*}{ Kerosene } & $15,000 \mathrm{gal}$ & $0.40 / \mathrm{ga} 1$ & 6,000 \\
\hline & & & $\$ 325,000$ \\
\hline
\end{tabular}




\subsubsection{Byproduct Production Cost}

Production costs for uranium byproducts are summarized below. These costs are approximately $\$ 1,459,000$ annually. Annual revenue is estimated at $\$ 30,862,000$ assuming a processing rate of $600 \mathrm{1b} / \mathrm{hr}$ of concentrate.

$\begin{array}{lr}\text { Depreciable Fixed Charge } & \$ 223,000 \\ \text { Fixed Charge on Land and Working Capital } & 12,000 \\ \text { Operating Costs } & 1,224,000 \\ \text { Production Cost } & \$ 1,459,000\end{array}$

\subsection{MAJOR UNCERTAINTIES}

Major areas of uncertainty affecting the $\mathrm{ThO}_{2}$ unit cost estimates include mine/mill capital cost, mine, mill, and refinery capital and operating costs, byproduct credit, plant capacity, and thorium recovery efficiency. Estimates for the ranges of uncertainties in these areas are:

$\begin{array}{ll}\text { Mine/Mill Capital Cost } & +50 \% \text { to }-10 \% \text { of calculated value } \\ \text { Mine/Mill Operating Cost } & +50 \% \text { to }-10 \% \text { of calculated value } \\ \text { Refinery Capital Cost } & +50 \% \text { to }-10 \% \text { of calculated value } \\ \text { Refinery Operating Cost } & +50 \% \text { to }-10 \% \text { of calculated value } \\ \text { Byproduct Credit } & \text { full credit to no credit with ful1 } \\ & \text { credit most } 1 \text { ikely } \\ \text { Plant Capacity } & 50,000 \text { to } 150,000 \text { tpd with most likely } \\ & \text { value of } 100,000 \text { tpd } \\ \text { Thorium Recovery Efficiency } & 32 \% \text { to } 74 \% \text { with most likely value of } \\ & 57 \%\end{array}$

The impact of these uncertainty ranges on the unit cost of $\mathrm{ThO}_{2}$ is shown in Table 14.10. From the incremental unit cost values, a Monte Carlo statistical analysis is performed using the procedure described in Section 16. From this analysis, a most likely value of $\$ 59.30 / 1 \mathrm{~b} \mathrm{ThO}_{2}$ and overal1 cost range of $\$ 36.70$ to $\$ 93.70 / 1 \mathrm{~b} \mathrm{ThO}_{2}$ is predicted for the unit cost of $\mathrm{ThO}_{2}$. 
TABLE 14.10. Uncertainty Ranges for Factors Affecting $\mathrm{ThO}_{2}$ Unit Cost

\begin{tabular}{|c|c|c|}
\hline & $\begin{array}{l}\text { Most Likely } \\
\text { Value } \\
\end{array}$ & Range \\
\hline Mine/Mill Capital Cost & $60,083^{(a)}$ & 90,125 to 54,075 \\
\hline Unit Capital Cost & 21.13 & 30.70 to 19.02 \\
\hline Incremental Unit Cost & & +10.57 to -2.11 \\
\hline Mine Operating Cost $\$ 10^{3} /$ year & $35,053^{(a)}$ & 52,580 to 31,548 \\
\hline Unit Operating Cost $\$ / 1 \mathrm{~b} \mathrm{ThO}_{2}$ & 12.33 & 18.49 to 11.10 \\
\hline Incremental Unit Cost $\$ / 1 \mathrm{~b} \mathrm{ThO}_{2}$ & & +6.16 to -1.23 \\
\hline Mi11 Operating Cost $\$ 10^{3} /$ year & $71,699^{(a)}$ & 107,549 to 64,529 \\
\hline Unit Operating Cost $\$ / 1 \mathrm{~b} \mathrm{ThO}_{2}$ & 25.22 & 37.83 to 22.70 \\
\hline Incremental Unit Cost $\$ / 1 \mathrm{~b} \mathrm{ThO}_{2}$ & & +12.61 to -2.52 \\
\hline $\begin{array}{l}\text { Unit Refinery Capital and Operating } \\
\text { Cost } \$ / 1 \mathrm{~b} \mathrm{ThO}_{2}\end{array}$ & 3.01 & 4.52 to 2.71 \\
\hline Incremental Unit Cost $\$ / 1 \mathrm{~b} \mathrm{ThO}_{2}$ & & +1.51 to -.30 \\
\hline Byproduct Credit \% & 100 & 100 to 0 \\
\hline $\begin{array}{l}\text { Unit Credit Cost } \$ / 1 \mathrm{~b} \mathrm{ThO} \\
\text { Incremental Unit Cost } \$ / 1 \mathrm{~b} \mathrm{ThO}_{2}\end{array}$ & -11.75 & $\begin{aligned}-11.75 & \text { to } 0 \\
0 & \text { to }+11.75\end{aligned}$ \\
\hline Plant Capacity tpd & 100,000 & 150,000 to 50,000 \\
\hline Unit Capacity Cost $\$ / 1 \mathrm{~b} \quad \mathrm{ThO}_{2}$ & 50.25 & 45.17 to 59.75 \\
\hline Incremental Unit Cost $\$ / 1 \mathrm{~b} \mathrm{ThO}_{2}$ & & -5.08 to +9.50 \\
\hline Thorium Recovery Efficiency \% & 57 & 32 to 74 \\
\hline Recovery Efficiency Cost $\$ / 1 \mathrm{~b} \mathrm{ThO}_{2}$ & 50.25 & 89.51 to 38.71 \\
\hline Incremental Unit Cost $\$ / 1 \mathrm{~b} \mathrm{ThO}_{2}$ & & +39.26 to -11.54 \\
\hline
\end{tabular}

(a) Depletion allowance (22\%) is subtracted from cost 



\section{REFERENCES}

1. Hurst, F. J., Crouse, D. J., and Brown, K. B., Recovery of Thorium and Uranium From Granitic Rocks. ORNL-3987, Oak Ridge National Laboratory, Oak Ridge, TN, October 1966.

2. Hurst, F. J., et a1., Estimated Costs for Recovery of Thorium and Uranium. ORill-3988, Oak Ridge National Laboratory, Oak Ridge, Ti, November 1966.

3. Merritt, R. C., The Extractive Metallurgy of Uranium. Colorado School of Mines, Golden, CO, 1971. 


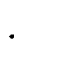




\subsection{PIEDMONT PLACER DEPOSITS}

\subsection{RESOURCE DESCRIPTION}

The United States Geological Survey ${ }^{(1)}$ estimates that there are about 784,000 short tons of monazite, a principal source of thorium in placer deposits located in the Inner Piedmont Belt between the Savannah River in South Carolina and the Catawba River in North Carolina. Fluviatile placers in flood plains constitute the main source of monazite in the area. Placers also exist north and south of this belt, but the monazite content was found to be sparse.

The USGS identified 84 placer deposits downstream from the river headwaters in broad, U-shaped valleys. These placers range from $1 \times 10^{6} \mathrm{yd}^{3}$ to $10 \times 10^{6} \mathrm{yd}^{3}$ of alluvium with an average of $3.1 \times 10^{6} \mathrm{yd}^{3}$. The deposits are an average of 14 to 16 feet thick and contain an average of $1.31 \mathrm{~b} / \mathrm{yd}^{3}$ of monazite. From these figures, the placers are estimated to contain about 375,000 tons of monazite which is contained mainly in the sandy gravel strata of the placer deposit.

0ther smaller, sparser placers also exist in the area. An additional 5,000 small placers deposits are located at the headwaters in narrow $\mathrm{V}$-shaped valleys. These deposits contain an estimated $20,000 \mathrm{yd}^{3}$ of aluvium per deposit with tenor of $5 \mathrm{lb} / \mathrm{yd}^{3}$ of monazite. These deposits account for approximately 250,000 short tons of monazite mineral. Monazite is widely disseminated in the fine sediments downstream of gravel-bearing placers. The average tenor of these sediments is about $.04 \mathrm{lb} / \mathrm{yd}^{3}$ of monazite. These sediments appear impractical to mine for thorium within the time frame of this study.

Over the time frame of this study, it is concluded that only the largest fluviatile placers in the flood plains deposits could be mined. Utilizing current mining technology, recovery efficiency is only about $58 \%$. Thus, the total amount of monazite available from Piedmont placer deposits is about 217,500 short tons.

The $\mathrm{ThO}_{2}$ content in the monazite of these deposits ranges from $5.27 \%$ to $5.83 \%$ with an average of $5.6 \%$. The rare earth oxide content is $62.8 \%$ and 
the $\mathrm{U}_{3} \mathrm{O}_{8}$ content ranges from $.18 \%$ to $.98 \%$ with an average between $.38 \%$ and $.52 \%$. Heavy minerals other than monazlte occurring in these placer deposits are as follows:

$\begin{array}{lc}\text { Heavy Mineral } & \frac{1 \mathrm{~b} / y \mathrm{~d}^{3} \text { Aluvium }}{\text { Ilmenite }} \\ \text { Rutile } & 5.3 \\ \text { Zircon } & .3 \\ & .6\end{array}$

The amount of reactor grade thorium that would be produced from the largest fluviatile placers is calculated to be 11,000 short tons of $\mathrm{ThO}_{2}$. In addition, these deposits would also yield approximately 123,000 tons of rare earth oxides, 400,000 tons of ilmenite, 23,000 tons of rutile, and 45,000 tons of zircon.

\subsection{PRELIMINARY MINE DESCRIPTION}

Since the Piedmont Placer deposits are remote and small in size, mine equipment must be relocated several times. For this reason, the conceptual mine model uses dragline (doodlebug) dredge methods. Dragline dredging is currently employed to recover precious minerals such as gold, tin, and diamonds. The equipment is especially adapted to mining in remote districts where water is at a premium. Advantages of dragline dredging over conventional dredge methods used currently for heavy mineral recovery include: (1) lower capital equipment cost, (2) greater ease of transporting equipment, and (3) smaller dredge pond requirements.

Dragline dredging is accomplished by 2 cubic yard crawler mounted draglines operating on dry land. These draglines feed a dredge wet mill which processes approximately $200 \mathrm{tph}$ of placer sand and discharges $675 \mathrm{lb} / \mathrm{hr}$ of heavy mineral concentrate to a stockpile adjacent to the dredge pond. The concentrate is dewatered and transported by truck to a dry mill.

The dry mill separates monazite from the heavy mineral concentrate by gravity and magnetic separation. To mine Piedmont Placers, approximately 15 dragline wet mill units will feed into the dry mill. The dry mill will 
process 56 tons per day of concentrate and produces 6.91 ton/day of a $95 \%$ monazite sand product. This concentrate is shipped to an extraction and refining facility similar to those described in a report by Enderlin(2).

The draglines and dredge are moved on an average interval of 2.5 years. The parts are dismantled and loaded into a truck for transport to a new deposit. The plant can be dismantled and reassembled in about one week.

\subsection{PRELIMINARY COST ESTIMATE}

A detailed cost estimate for Piedmont Placers was not developed since the preliminary estimate of mining costs exceeded $\$ 142 / 1 \mathrm{~b} \mathrm{ThO} \mathrm{T}_{2}$. Assuming full byproduct credit for ilmenite, rutile, and zircon would reduce the cost to $\$ 140 / 1 \mathrm{~b} \mathrm{ThO} \mathrm{C}_{2}$. Thus, the cost of thorium from the Piedmont Placers would exceed the cost of thorium from the most expensive resource studied - Conway Granite. Because of the large reserve contained in the Conway Granite, we conclude that the Piedmont Placers will not be mined within the timeframe of this analysis. 

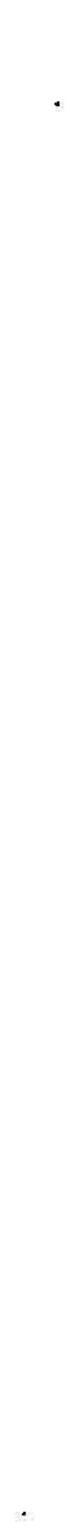

\section{.}




\section{REFERENCES}

1. W. C. Overstreet, et al., Fluvial Monazite Deposits in the Southeastern United States, U.S. Geological Survey Professional Paper 568, 1968, p. 85 , plates in pocket.

2. W. I. Enderlin, An Assessment of U.S. Domestic Capacity for Producing Reactor Grade $\mathrm{ThO}_{2}$ and Controlling Associated Wastes and Effluents, Batte11e Northwest Laboratories, PNL-2593, February 1978. 
. 


\subsection{UNCERTAINTY ANALYSIS}

\subsection{INTRODUCTION}

In estimating the production cost for $\mathrm{ThO}_{2}$ from each resource, we first established the "most likely" estimates for each major variable, e.g., ore grade, capital cost recovery rate, etc. We called these the "reference conditions". We then determined the production cost under the reference conditions.

However, there is considerable uncertainty surrounding the true value for each variable, particularly in a study of this nature. For example, although the most likely value for ore grade is estimated to be $1 \%$, the uncertainty is such that the true value might lie anywhere in a range from 0.5 to $2.0 \%$. In this case the probability of the true value occuring at a specific point in this range can only be expressed through a statistical distribution. Since a similar statistical distribution is applied to many of the major variables in this study, we used a computer code, OPS*, to calculate production costs based on the joint probabilities of occurrence at specific values.

\subsection{COMPUTER ANALYSIS}

OPS calculates the distribution of production costs for reactor grade $\mathrm{ThO}_{2}$ based on high, most likely, and low estimates of cost variables. In order to illustrate the OPS procedure for determining price variation, the Palmer, Michigan uncertainty analysis will be discussed. In this case an open pit mine is designed to produce 10,000 tons per day of ore which is concentrated and refined to reactor grade $\mathrm{ThO}_{2}$. The major cost variables are as follows:

1. Mine/mill operating costs

2. Mine/mill capital costs

3. Refinery operating costs

* R. W. Legan and R. L. Engel, OPS: Risk Analysis in Capital Investment and Development Opportunities, BNWL-1562, May 1972. 
4. Refinery capital costs

5. Ore recovery

6. Byproduct credit

For each of the variables the high, most likely, and low values are estimated (Table 16.1). These values are then translated into the equivalent $\mathrm{ThO}_{2}$ production costs as described in Section 6.0. Items 1 through 4 are costs based on the most likely thorium recovery. Item 5 accounts for cost differences based on the variability in ore recovery.

TABLE 16.1. Uncertainty Ranges $\mathrm{ThO}_{2}$ Unit Cost of Palmer, Michigan

\begin{tabular}{|c|c|c|}
\hline & $\begin{array}{c}\text { Most Likely } \\
\text { Value } \\
\end{array}$ & Range \\
\hline Mine/Mill Capital Cost $\$ 10^{3} /$ year & 35,034 & 52,551 to 31,530 \\
\hline Unit Cost $\$ / 1 \mathrm{~b} \mathrm{ThO}_{2}$ & 5.45 & 8.17 to 4.90 \\
\hline Mine/Mil1 Operating Cost $\$ 10^{3} /$ year & 34,903 & 52,354 to 31,412 \\
\hline Unit Cost $\$ / 1 \mathrm{~b} \mathrm{ThO}_{2}$ & 5.43 & 8.14 to 4.88 \\
\hline Refinery Capital Cost $\$ 10^{3} /$ year & 4,152 & 6,228 to 3,737 \\
\hline Unit Cost $\$ / 1 \mathrm{~b} \mathrm{ThO}_{2}$ & .65 & .97 to .58 \\
\hline Refinery Operating Cost $\$ 10^{3} /$ year & 8,519 & 12,779 to 7,667 \\
\hline Unit Cost $\$ / 1 \mathrm{~b} \mathrm{ThO} 2$ & 1.32 & 1.99 to 1.19 \\
\hline Ore Recovery (\%) & 56 & 50 to 62 \\
\hline Unit Cost $\$ / 1 \mathrm{~b} \mathrm{ThO}$ & 12.88 & 14.43 to 11.63 \\
\hline Byproduct Credit & No Credit & Up to $\$ 12 \mathrm{Mi} 11$ ion $/ \mathrm{yr}$ \\
\hline Unit Cost $\$ / 1 \mathrm{~b} \mathrm{ThO}_{2}$ & 0 & 0 to -1.87 \\
\hline
\end{tabular}

Since the probability distribution for these variables is not known, OPS assigns a beta probability distribution to each cost item. The Monte Carlo simulation method is utilized to select a single random value from each distribution. The Monte Carlo method is such that the most likely values are generated more often than unlikely values, but the specific outcome of any simulation is unpredictable. The cost simulation is done over and over again to obtain a statistically significant distribution of possible 
costs for $\mathrm{ThO}_{2}$. Other output from the code includes:

1. Number of simulations

2. Average cost

3. Standard deviation

4. Maximum value observed

5. Minimum value observed

6. Skewness estimate

7. Kurtosis estimate

Skewness is a measure of assymetry. If this value is less than zero, the distribution is skewed to left; greater than zero, the distribution is skewed to the right.

Kurtosis is a measure of peakedness. If this value is greater than 3.0, the distribution is more peaked than a standard distribution; if less than 3.0, the distribution is less than a normal distribution. A flat distribution has a value of 1.8 .

The output for Palmer, Michigan is shown in Table 16.2.

TABLE 16.2. Uncertainty Analysis for Palmer, Michigan Deposit Number of Entries in Table

Average

Standard Deviation

The Maximum Value is

The Minimum Value is

Skewness Estimate from Moments $-.00935$

Skewness Estimate from K-Statistics

The distribution is skewed to the left; that is, it has a left (low) tail.

Kurtosis Estimate from Moments

Kurtosis Estimate from K-Statistics

The distribution is less peaked than a normal distribution. A value of 1.8 is a flat distribution. 
Data indicates the expected cost for Palmer, Michigan thorite is between $\$ 17.00$ and $\$ 9.70$. The average cost is $\$ 13.30$. The standard deviation is $\$ 1.80$. This means that $68.3 \%$ of the time the price of thorium would range from $\$ 11.58-\$ 15.10$.

OPS also prints a histogram of the distribution curve. The data in Table 16.2 are illustrated in Figure 16.1. The average (mean) cost represented by the letter "A" is approximately $\$ 13.50$, but the most likely (modal) cost is $\$ 14.20$.

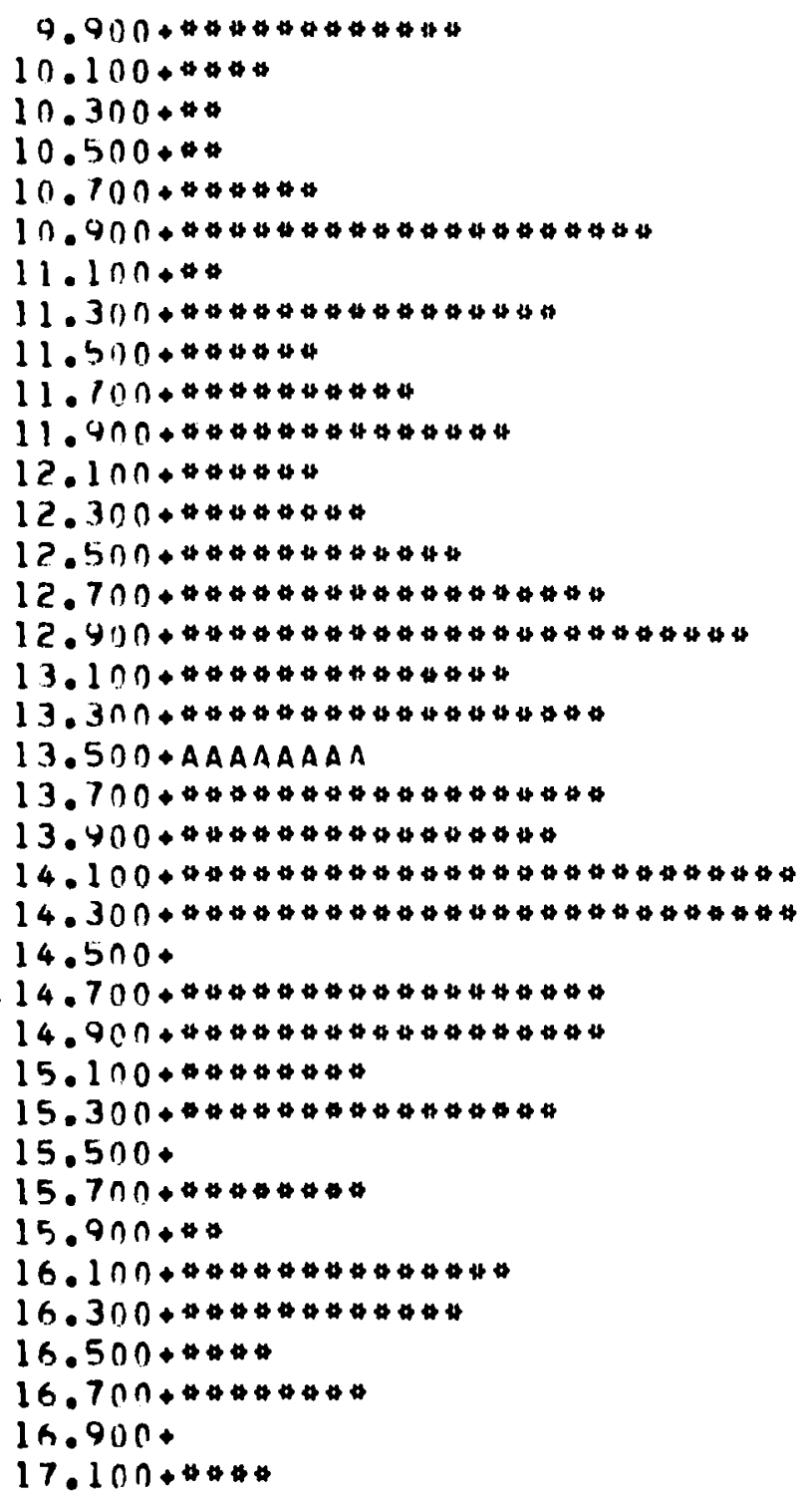

FIGURE 16.1. Distribution of Unit Cost for Palmer, Michigan 
Table 16.3 is a frequency table. The table presents for several intervals of calculated values:

1. The frequency

2. The relative frequency (percent)

3. Cumulative percentages

4. Cumulative remainder (100 minus item 3 )

TABLE 16.3. Frequency Distribution for Palmer, Michigan

\begin{tabular}{|c|c|c|c|c|}
\hline $\begin{array}{l}\text { Upper } \\
\text { Limit }\end{array}$ & $\begin{array}{l}\text { Observed } \\
\text { Frequency }\end{array}$ & $\begin{array}{l}\text { Percent } \\
\text { of Total }\end{array}$ & $\begin{array}{l}\text { Cumulative } \\
\text { Percentage }\end{array}$ & $\begin{array}{l}\text { Cumulative } \\
\text { Remainder }\end{array}$ \\
\hline 9.90 & 6 & 3.00 & 3.00 & 97.00 \\
\hline 10.10 & 2 & 1.00 & 4.00 & 96.00 \\
\hline 10.30 & 1 & .50 & 4.50 & 95.50 \\
\hline 10.50 & $i$ & .50 & 5.00 & 95.00 \\
\hline 10.70 & 3 & 1.50 & 6.50 & 93.50 \\
\hline 10.90 & 10 & 5.00 & 11.50 & 88.50 \\
\hline 11.10 & 1 & .50 & 12.00 & 88.00 \\
\hline 11.30 & 8 & 4.00 & 16.00 & 84.00 \\
\hline 11.50 & 3 & 1.50 & 17.50 & 82.50 \\
\hline 11.70 & 5 & 2.50 & 20.00 & 80.00 \\
\hline 11.90 & 7 & 3.50 & 23.50 & 76.50 \\
\hline 12.10 & 3 & 1.60 & 25.00 & 75.00 \\
\hline 12.30 & 4 & 2.00 & 27.00 & 73.00 \\
\hline 12.50 & 6 & 3.00 & 30.00 & 70.00 \\
\hline 12.70 & 9 & 4.50 & 34.50 & 65.50 \\
\hline 12.90 & 12 & 6.00 & 40.50 & 59.50 \\
\hline 13.10 & 7 & 3.50 & 44.00 & 56.00 \\
\hline 13.30 & 9 & 4.50 & 48.50 & 51.50 \\
\hline 13.50 & 4 & 2.00 & 50.50 & 49.50 \\
\hline 13.70 & 9 & 4.50 & 55.00 & 45.00 \\
\hline 13.90 & 8 & 4.00 & 59.00 & 41.00 \\
\hline 14.10 & 13 & 6.50 & 65.50 & 34.50 \\
\hline 14.30 & 13 & 6.50 & 72.00 & 28.00 \\
\hline 14.50 & 0 & .00 & 72.00 & 28.00 \\
\hline 14.70 & 9 & 4.50 & 76.50 & 23.50 \\
\hline 14.90 & 9 & 4.50 & 81.00 & 19.00 \\
\hline 15.10 & 4 & 2.00 & 83.00 & 17.00 \\
\hline 15.30 & 8 & 4.00 & 87.00 & 13.00 \\
\hline 15.50 & 0 & .00 & 87.00 & 13.00 \\
\hline 15.70 & 4 & 2.00 & 89.00 & 11.00 \\
\hline 15.90 & 1 & .50 & 89.50 & 10.50 \\
\hline 16.10 & 7 & 3.50 & 93.00 & 7.00 \\
\hline 16.30 & 6 & 3.00 & 96.00 & 4.00 \\
\hline 16.50 & 2 & 1.00 & 97.00 & 3.00 \\
\hline 16.70 & 4 & 2.00 & 99.00 & 1.00 \\
\hline 16.90 & 0 & .00 & 99.00 & 1.00 \\
\hline 17.10 & 2 & 1.00 & 100.00 & .00 \\
\hline
\end{tabular}


The cumulative percentage estimates the probability that the calculated attribute will be less than a certain amount. The cumulative remainder tells us the probability that the calculated value will be more than a certain amount. Thus, for Palmer, Michigan, there is a $5 \%$ chance that $\mathrm{ThO}_{2}$ will cost less than $\$ 9.90$ or cost more than $\$ 17.10$.

\subsection{RESULTS}

The uncertainty analysis method utilized for Palmer, Michigan was employed for all deposits. The results are shown in Table 16.4. Frequency tables for each deposit are shown in Appendix $F$.

TABLE 16.4. Range of Unit costs for Thorium Oxide

\begin{tabular}{|c|c|c|c|}
\hline Deposit & Most Likely Value & High Value & Low Value \\
\hline \multicolumn{4}{|l|}{ Stockpiles } \\
\hline Fernald & 2.80 & 4.20 & 2.00 \\
\hline $\begin{array}{l}\text { Miamisburg } \\
\text { Curtis Bay }\end{array}$ & 4.10 & 5.60 & 2.90 \\
\hline Chattanooga & 5.80 & 8.50 & 4.30 \\
\hline $\begin{array}{l}\text { Lemhi Pass } \\
\text { (Stage 1) }\end{array}$ & 15.70 & 22.90 & 10.80 \\
\hline $\begin{array}{l}\text { Lemhi Pass } \\
\text { (Stage 2) }\end{array}$ & 12.10 & 17.40 & 8.90 \\
\hline Hall Mountain & 6.30 & 9.30 & 5.60 \\
\hline Wet Mountain & 8.30 & 13.30 & 5.90 \\
\hline Palmer & 14.20 & 17.10 & 9.70 \\
\hline Bald Mountain & 49.00 & 68.00 & 29.00 \\
\hline Bear Lodge & 57.40 & 84.90 & 34.20 \\
\hline Conway Granite & 59.30 & 88.20 & 38.00 \\
\hline
\end{tabular}




\subsection{DOMESTIC THORIUM SUPPLY CURVE}

\subsection{DESCRIPTION}

The supply curve illustrates that sufficient amounts of thorium exist to supply a domestic thorium-reactor economy. Most likely costs of production range from $\$ 3$ to $\$ 60 / 1 \mathrm{~b} \quad \mathrm{ThO}_{2}$. Costs including undertainty range from $\$ 2$ to $\$ 88 / 1 \mathrm{~b} \mathrm{ThO} \mathrm{T}_{2}$. Near-term thorium oxide resources include the stockpiles in Ohio, Maryland, and Tennessee and the thorite deposits at Hall Mountain, Idaho. Costs are under $\$ 10 / 1 \mathrm{~b}$ thorium oxide. Longer term economic deposits include Wet Mountain, Colorado; Lemhi Pass, Idaho; and Palmer, Michigan. Most likely costs are under $\$ 20 / 1 \mathrm{~b}$ thorium oxide. Long-term deposits include Bald Mountain, Wyoming; Bear Lodge, Wyoming; and Conway, New Hampshire. Costs approximately equal or exceed $\$ 50 / 1 \mathrm{~b}$ thorium oxide.

The supply curve for thorium oxide was developed for domestic thorium resources (see Figure 17.1). The curve illustrates the relationship between

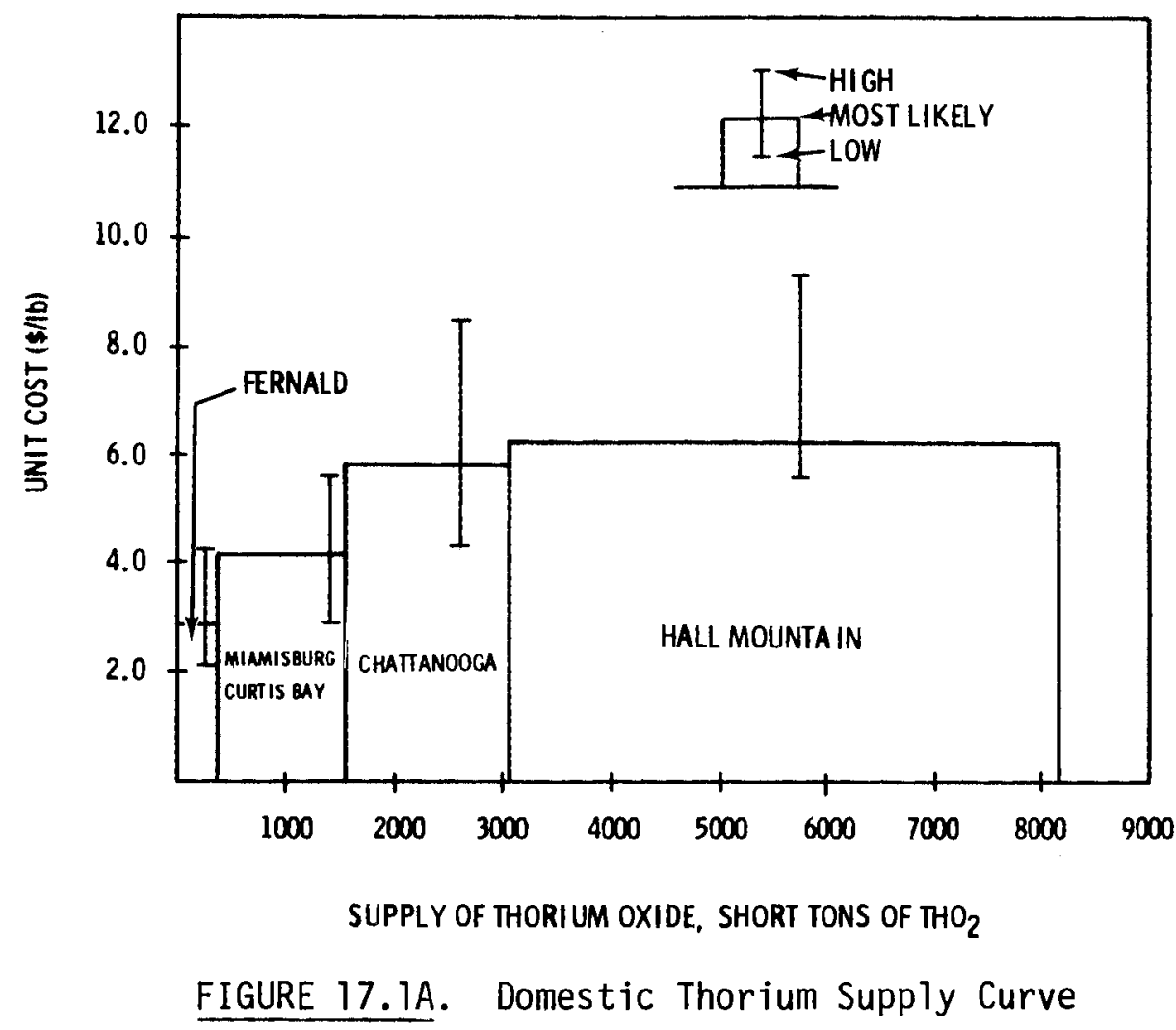




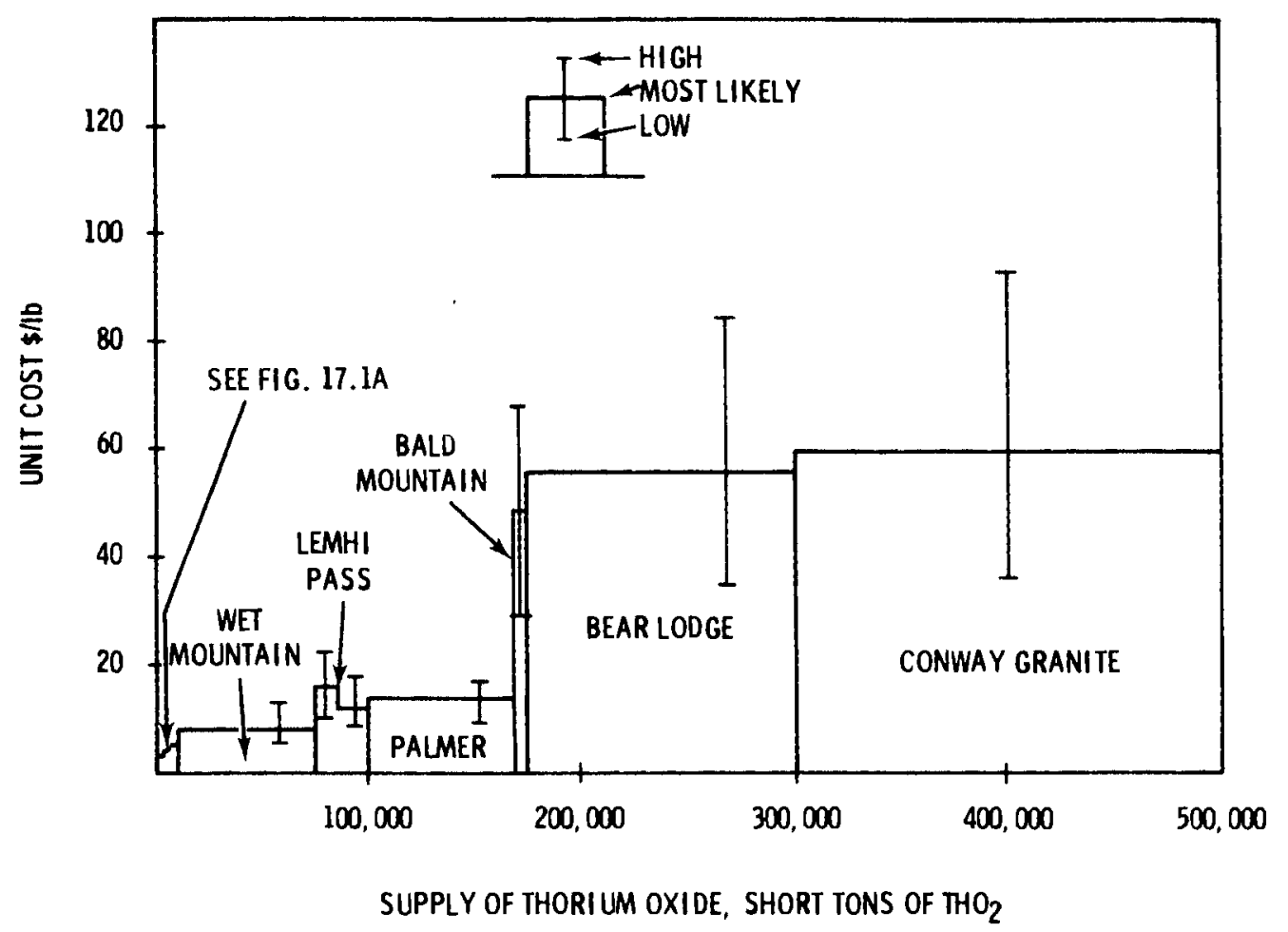

FIGURE 17.1B. Domestic Thorium Supply Curve

production costs and quantity of thorium oxide available. All production costs are in 1978 dollars. Production cost figures include costs for baseline environmental control. The effect of more stringent environmental control measures will be developed in a subsequent report.

In the supply curve, the quantity of reserves is illustrated for each deposit as a function of the most likely production cost by a rectangular area on the supply curve. A double arrow drawn perpendicular to the top of the rectangle illustrates high and low cost estimates for each resource. Resources are arrayed by plotting production costs in increasing order except for Lemhi Pass. The Lemhi Pass resource shows a decrease in cost because Lemhi Pass is mined in two stages. The first stage of mining is higher because a lower grade of ore is developed. As mining progresses, higher grades of ore are accessed (second stage) and production costs decrease.

The supply curve shows production costs for proven reserves oniy unless data is available to allow cost estimates for probable and potential resources. 
Data used to develop the supply curve is derived from the production costs and the quantity of reserves developed which are summarized in Table 17.1. The total estimated amount of reserves are also shown. To the extent that these additional reserves can be developed, the supply curve would shift downward.

TABLE 17.1. Summary of Development Costs for Domestic $\mathrm{ThO}_{2}$ Resources

\begin{tabular}{|c|c|c|c|c|}
\hline Resource & $\begin{array}{l}\text { Production } \\
\text { Most Likely }\end{array}$ & $\begin{array}{l}\text { Costs } \\
\text { Range } \\
\end{array}$ & $\begin{array}{l}\text { Quantity } \\
\text { Recovered } \\
\text { Short Tons } \\
\end{array}$ & $\begin{array}{l}\text { Quantity } \\
\text { in } \\
\text { Deposit } \\
\text { Short Tons (a) } \\
\end{array}$ \\
\hline Fernald & 5.80 & $\$ 4.30-\$ 8.50$ & $\simeq 1,500$ & 1,500 \\
\hline Miamisburg & 4.10 & $\$ 2.90-\$ 5.60$ & $\simeq 800$ & 800 \\
\hline Curtis Bay & 4.10 & $\$ 2.90-\$ 5.60$ & $\simeq 400$ & 400 \\
\hline Chattanooga & 5.80 & $\$ 4.30-\$ 8.50$ & $\simeq 360$ & 360 \\
\hline Lemhi Pass & $13.90^{(b)}$ & $\$ 22.90-\$ 8.90$ & 23,000 & 187,700 \\
\hline Hall Mountain & 6.30 & $\$ 5.60-\$ 9.30$ & $\simeq 5,000$ & 35,000 \\
\hline Wet Mountain & 8.30 & $\$ 5.90-\$ 13.30$ & 61,000 & 224,900 \\
\hline Palmer & 14.20 & $\$ 9.90-\$ 17.10$ & 70,000 & 193,000 \\
\hline Bear Lodge ${ }^{(b)}$ & 57.40 & $\$ 34.20-\$ 84.90$ & 137,000 & $1,620,000$ \\
\hline Bald Mountain & 49.00 & $\$ 29.00-\$ 68.00$ & $\simeq 2,600$ & Unknown \\
\hline Conway Granite & 59.30 & $\$ 36.70-\$ 93.70$ & (c) & $35,000,000$ \\
\hline
\end{tabular}

(a) includes estimates for probable and potential reserves

(b) average costs

(c) ample to melet maximum demand

Low cost resources that would be developed to satisfy near-term requirements for thorium oxide include the stockpiles in Fernald, Ohio; Miamisburg, Ohio; Curtis Bay, Maryland; Chattanooga, Tennessee and the thorite deposit at Hall Mountain. Approximately 8,000 short tons of thorium oxide are available from these resources at a cost below $\$ 10 / 7 \mathrm{~b}$. These resources could adequately supply thorium oxide for prototype purposes and small-scale commercialization of the thorium fuel cycle.

The longer-term economic thorium deposits include Wet Mountain, Colorado; Lemhi Pass, Idaho; and Palmer, Michigan. These deposits represent 
approximately 160,000 short tons of thorium oxide. The resources could support thorium reactor-growth and development for at least the next 50 years under the most likely demand conditions with costs ranging from $\$ 8$ to $\$ 17 / 1 \mathrm{~b}$.

Long term deposits for thorium include Bald Mountain, Wyoming; Bear Lodge, Wyoming; and Conway, New Hampshire. These deposits represent over $17 \mathrm{million}$ tons of thorium oxide. The resources could support a thorium fuel cycle for hundreds of years. Costs approximately equal or exceed $\$ 50 / 1 \mathrm{~b}$ of thorium oxide.

Costs illustrated on the supply curve do not include mine reclamation. Charges for reclamation may decrease the attractiveness of the large surfacedeposits such as Conway Granite, Bear Lodge, and Palmer, Michigan. Reclamation was not analyzed in this report because we assumed that during the time frame of this study the pits would remain open. Thus, when economic conditions favor mining the low-grade ore bordering the pit, the ore can be easily accessed.

The supply curve will aid in the evaluation of the thorium fuel cycle. Feedstock costs, the other costs of the fuel cycle, and fuel exposures can be used to calculate energy costs. Thus, the economic viability of the thorium cycle can be analyzed.

\subsection{COMPARISON WITH U.S.G.S. ESTIMATES}

The United States Geological Survey (U.S.G.S.) recently reassessed several principal thorium resources in the United States. (1) Thorium districts discussed both in our study and the new U.S.G.S. report include Lemhi Pass, IdahoMontana; Hall Mountain, Idaho; Wet Mountains, Colorado; Bear Lodge, Wyoming; and the Piedmont Placers of North and South Carolina. Most of the estimates generated by the U.S.G.S. report agree with the cost estimates obtained in our study. Deposit comparisons are discussed in the following paragraphs.

Both studies show close agreement for the Hall Mountain resource. According to our study, the Hall Mountain deposit contains approximately 5000 tons of reserves at an estimated $\$ 6.30 / 1 \mathrm{~b} \mathrm{Th0_{2 }}$. The U.S.G.S. study reports 
4540 tons of $\mathrm{ThO}_{2}$ reserves available at under $\$ 5 / 1 \mathrm{~b}$. The U.S.G.S. also estimates 29,100 tons of probably-potential reserves which are beyond the scope of our study.

Small discrepancies exist in the Wet Mountain resource analyses. The Wet Mountains deposit contains 54,100 reserves available at under \$15/1b according to the U.S.G.S. and 9820 tons of reserves available at higher costs. Approximately 60,000 tons of $\mathrm{ThO}_{2}$ reserves are reported in our study at $\$ 8.30 / 1 \mathrm{~b} \mathrm{ThO}_{2}$. The new and better data collected during the recent U.S.G.S. thorium reassessment program has enabled them to more accurately determine reserve data. However, the discrepancies in the amount recoverable has a negligible effect on the supply curve. Both studies illustrate the importance of the Wet Mountains area in the closer-term supply picture.

The U.S.G.S. utilizes larger reserve estimates than our study. According to the U.S.G.S. approximately 54,100 tons of reserves could be produced from Lemhi Pass at costs under $\$ 15 / 1 \mathrm{~b}$ of $\mathrm{ThO}_{2}$, 2540 tons of reserves at costs between $\$ 15 / 1 \mathrm{~b}$ and $\$ 30 / 1 \mathrm{~b}$, and 7,280 tons of reserves at costs between $\$ 30 / 7 \mathrm{~b}$ and $\$ 50 / 1 \mathrm{~b}$. Our study evaluates 23,000 tons at $\$ 12 / 1 \mathrm{~b}$ to $\$ 16 / 1 \mathrm{~b}$ of $\mathrm{ThO}_{2}$. Part of the discrepancy can be resolved because the U.S.G.S. study assumes higher ore grades and higher mine recoveries than we assumed for this analysis resulting in recovery of more thorium per pound of ore. Also, additional veins were discovered and included in Staatz reserve estimate based on data unavailable during the course of our study.

Thus, there are probably additional reserves at Lemhi Pass not indicated on our supply curve. We did not undertake additional analysis with the new U.S.G.S. data because the additional reserve would cause only a minor change in the overall supply curve.

The North and South Carolina placer deposits were also evaluated. Because of their small size and low grade, both studies conclude that none of the Piedmont placers could be operated at costs less than $\$ 50 / 1 \mathrm{~b} \mathrm{Th0_{2 }}$. This study indicates the cost would exceed $\$ 100 / 1 \mathrm{~b} \mathrm{ThO}_{2}$.

The Bear Lodge, Wyoming deposit was also discussed by the U.S.G.S., however cost analysis was not completed. An earlier report by Staatz $(2)$ estimated 
228,000 tons of $\mathrm{ThO}_{2}$ potentially exist in the Bear Lodge Mountains. This study estimates it would cost approximately $57.00 / 1 \mathrm{~b} \mathrm{Th0_{2 }}$ to develop these reserves because of the difficulty in beneficiating the ore and concentrating the thorium.

Several resources discussed in our report but beyond the scope of the U.S.G.S. study are located in Palmer, Michigan, Bald Mountain, and Conway, New Hampshire. These deposits offer substantial quantities of thorium and play potentially important roles in the thorium supply picture.

Several deposits are analyzed in the U.S.G.S. study, but are not included in our study (see Section 5.0). Although many of these deposits may someday be developed for thorium, they were excluded from our study due to lack of data, their small size, or their lack of economic feasibility.

The supply curve for thorium illustrates the importance of various deposits in the domestic supply picture. As new exploration programs are undertaken, more thorium will probably be found in all ranges of production costs. Current data indicates, however, that there are abundant sources of thorium in the United States with economically feasible production costs. 


\section{REFERENCES}

1. M. H. Staatz, T. J. Armbrustmacher, J. C. 01 son et al., Principal Trorium Resources in the United States, U.S.G.S. circ. 805, U.S. Geological Survey, Co., 42 pp., 1978.

2. M. H. Staatz, Proceedings of the Uranium Industry Seminar, 1978, GJ0-108(78), U.S. Dept. of Energy, Grand Junction, Colorado, pp. 109-115. 

APPENDIX A

BUILDING AND EQUIPMENT COSTS

The following tables show the detailed building and equipment costs for each thorium facility described in the text. 
TABLE A-1.1. Stockpiled Thorium Buildings and Equipment Cost for Refinery

Equipment

2 - 100 gal Dissolvers

2 - 100 gal Decantors

2 - 100 gal Adjustment Tanks

60 - Mixer Settlers

3 - 100 gal Boil Down Tanks

1 - Single Effect Evaporator

1 - Condensor

2 - 40 gal Mixers

1 - Rotary Vacuum Filter

1 - Vacuum Pump

1 - Plate and Frame Press

1 - Twin Screw Dryer

1 - Variable Speed Feeder

1 - Rotary Calciner

1 - Conveyor

1 - Elevator

1 - Drum Loader

1 - 400 gal Carbonate Mixing Tank

1 - 1000 gal HNO Mixing Tank

1 - 70,000 gal $\mathrm{HNO}_{3}$ Storage Tank

1 - 1000 gal Raffinate Holding Tank

2 - 2000 gal Solvent Storage Tanks

1 - 15,000 gal Water Tank

30 - Pumps ( $1 " \times 2$ ")

Process Equipment Capital Cost (PECC)

Field Erection (14\% of PECC)

Foundations ( $12 \%$ of PECC)

Piping and Chuting (22\% of PECC)

Electrical (19.5\% of PECC)

Instrumentation ( $5 \%$ of PECC)

Miscellaneous Site Preparation (5\% of PECC)

Buildings (35\% of PECC)

Service Facilities ( $55 \%$ of PECC)

Land ( $6 \%$ of PECC)

Total Physical Cost (TPC)

Engineering and Construction (25\% of TPC)

Direct Plant Cost (DPC)

Contractors Fee (5\% of DPC)

Total Plant Cost

Land

TOTAL Building and Equipment Costs
Cost

$\$ 10,000$

10,000

10,000

77,000

105,000

92,000

9,000

11,000

37,000

5,000

6,000

25,000

2,000

32,000

2,000

2,000

4,000

7,000

11,000

13,000

5,000

13,000

8,000

30,000

$\$ 526,000$

74,000

63,000

116,000

102,000

26,000

26,000

185,000

289,000

31,000

$\$ 1,438,000$

359,300

$\$ 1,797,000$

90,000

$\$ 1,887,000$

$\frac{-31,000}{\$ 1,856,000}$ 
TABLE A-1.2. Stockpiles Effluent Control Bufldings and Equipment Cost for Refinery

$\begin{array}{lr}6000 \text { cfm Bag House Filter } & 10,700 \\ 6000 \text { cfm HEPA Filter } & 21,600 \\ \text { Dehumidifier/Heater Unit } & 2,200 \\ \quad \text { Process Equipment Capital Cost } & 34,500 \\ \text { Field Erection (14\% of PECC) } & 4,800 \\ \text { Foundations (12\% of PECC) } & 4,100 \\ \text { Piping and Chuting (22\% of PECC) } & 7,600 \\ \text { Electrical (19.5\% PECC) } & 6,700 \\ \text { Instrumentation (5\% of PECC) } & 1,700 \\ \text { Miscellaneous Site Preparation (5\% of PECC) } & 1,700 \\ \text { Buildings (35\% of PECC) } & 12,100 \\ \text { Service Facilities (55\% of PECC) } & 19,000 \\ \text { Land (6\% of PECC) } & 2,100 \\ \quad \text { Total Physical Cost } & 94,300 \\ \text { Engineering and Construction (25\% of TPC) } & \underline{23,600} \\ \quad \text { Direct Plant Cost } & 117,900 \\ \text { Contractor's Fee (5\% of DPC) } & 5,900 \\ \quad \text { Total Plant Cost } & 123,800 \\ \text { Land } & -2,100 \\ \quad \text { Total Buildings and Equipment Cost } & 121,700\end{array}$


TABLE A-2.1. Lemhi Pass Buildings and Equipment Cost for Mil1

Component

$1-$

2-

$1-$

$1-$

2-

$1-$

$1-$

2-

2-

2-

$12-$

2-

$1-$

9-

2-

$7-$

2-

$1-$

$1-$

$1-$

$1-$

$1-$

$1-$

$1-$

$1-$

$1-$

3-

3-

$1-$

$1-$

Sampler

Thickener
Run of Mine Storage

Front End Loader

Primary Crusher

Secondary Crusher

Vibrating Screens

Crushed Ore Bin

Ball Mills

$2100 \mathrm{Gal}$. Agitated Tank

2500 Gal. Agitated Tank

$3500 \mathrm{Ga}$. Agitated Tank

4300 Gal. Agitated Tank

Pressure Leaf Filter

Vacuum Pump

$2500 \mathrm{Ga}$. Mixer/Settler

Strip Solution Prep Tanks

Disk Centrifuge

Rotary Vacuum Filter

Twin Screw Dryer

Rotary Calciner

Cyclone Dust Collector

Bag Filter

Centrifugal Fan

Drum Loader

550,000 Gal. Acid Tank

Solvent Tanks

Flocculant Tanks

1,000,000 Water Tank

Steam Generator

Materials Handiing Equipment

Pumps
Total

30,000

120,000

55,000

97,000

50,000

20,000

19,000

620,000

70,000

74,000

80,000

104,000

130,000

162,000

60,000

266,000

20,000

120,000

543,000

134,000

185,000

12,000

10,000

2,000

7,000

59,000

28,000

20,000

164,000

116,000

242,000

215,000

$3,834,000$

Process Equipment Capital Cost

A. 3 
TABLE A-2.1. (Continued)

Field Erection (14\% of PECC) $\quad 537,000$

Foundations ( $12 \%$ of PECC) $\quad 460,000$

Piping and Chuting (22\% of PECC) $\quad 843,000$

Electrical (19.5\% of PECC) $\quad 748,000$

Instrumentation ( $5 \%$ of PECC) 192,000

Misc. Site Preparation (5\% of PECC) 192,000

Buildings (35\% of PECC) 134,000

Service Facilities ( $55 \%$ of PECC) $\quad 211,000$

Land ( $6 \%$ of PECC)

Total Physical Cost (TPC)

$-230,000$

Engineering and Construction Overhead

(25\% of TPC)

Direct Plant Cost (DPC)

$7,381,000$

Contractors Fee ( $5 \%$ of DPC)

Total Plant Cost

$1,845,000$

$9,226,000$

461,000

$9,687,000$

Land

230,000

Total Buildings and Equipment Cost

$9,917,000$ 
TABLE A-2.2. Lemhi Pass Effluent Control Buildings and Equipment Cost for $\mathrm{Mi} 11$

26,000 cfm Cyclone

$\$ 6,600$

$21,000 \mathrm{cfm}$ Wet Impingement Scrubber

$\$ 13,300$

4,000 cfm Baghouse Filter

$\$ 7,600$

Process Equipment Capital Cost.

$\$ 27,500$

Field Erection ( $14 \%$ of PECC)

3,800

Foundations ( $12 \%$ of PECC)

3,300

Piping and Chuting (22\% of PECC)

6,000

Electrical (19.5\% of PECC)

5,400

Instrumentation ( $5 \%$ of PECC)

1,400

Miscellaneous Site Preparation (5\% of PECC)

1,400

Buildings ( $35 \%$ of PECC)

9,600

Service Facilities ( $55 \%$ of PECC)

15,000

Land $(6 \%$ of PECC)

1,600

Total Physical Cost

$\$ 75,000$

Engineering and Construction

18,700

(Overhead (25\% of TPC)

Direct Plant Cost

93,700

Contractor's Fee (5\% of DPC)

4,700

98,400

Land

1,600

$\$ 96,800$

30,000

Water Tank Truck

15,000

Storage Pile Barriers

$\$ 142,000$ 
TABLE A-2.3. Lemhi Pass: Sulfuric Acid Plant Buildings and Equipment Cost

Summary of Predesign Capital Cost Estimate for Thorite Mill Sulfuric Acid Plant

Plant Total Physical Cost

Engineering and Construction Overheads (25\% of TPC)

Direct Plant Cost

Contractors Fee (5\% of DPC)

Total Plant Cost

Land
$1,818,000$

454,000

$2,272,000$

114,000

$2,386,000$

109,000

$2,495,000$ 
TABLE A-3.1. Pa1mer, Michigan Buildings and Equipment cost for Refinery

\section{Equipment}

1 - Monazite Storage Hopper

3 - Ba11 Mi11

10 - 600 gal. Agitated Tanks

1 - Leaf Type Pressure Filter

9 - 600 gal. Mixer Settler

1 - Acid Mixer

1 - Strip Solution Mixer

1 - Caustic Mixer

1 - 240 sq. ft. Drum Filter

1 - 150 sq. ft. Drum Filter

1 - 3000 sq. ft. Screw Dryer

1 - $6^{\prime} \times 50^{\prime}$ Rotary Calciner

1 - 2000 CFM Fan

1 - 6000 CFM Cyclone Dust Collector

1 - 6000 CFM Bag Filter

1 - Bag Machine

2 - Vacuum Pumps

Material Handling Equipment

Pumps

Process Equipment Capital Cost

Field Erection (14\% of PECC) $(1)$

Foundations ( $12 \%$ of PECC) $(1)$

Piping and Chuting (22\% of PECC) ${ }^{(1)}$

Electrical ( $19.5 \%$ of PECC) ${ }^{(1)}$

Instrumentation ( $5 \%$ of PECC) ${ }^{(1)}$

Miscel1aneous Site Preparation (5\% of PECC) $(1)$

Building ( $35 \%$ of PECC) (1)

Service Facilities ( $55 \%$ of PECC) ${ }^{(1)}$

Land $(6 \%$ of PECC) $(1)$

Total Physical cost (TPC)

Engineering and Construction (25\% of TPC) ${ }^{(1)}$

Direct Physical Cost (DPC)

Contractor's Fee (5\% of DPC) ${ }^{(1)}$

Total Plant Cost

Land $\underline{\text { Cost }}$

$\$ 4,700$

180,000

552,000

223,800

337,900

21,000

21,000

21,000

112,600

87,500

119,000

450,000

2,100

10,600

12,000

9,800

92,800

110,000

215,000

$\$ 2,582,800$

361,600

309,900

568,200

503,600

129,100

129,100

904,000

$1,420,500$

155,000

$\$ 7,063,800$

$1,765,900$

$\$ 8,829,700$

441,500

$\$ 9,271,200$

$-155,000$

$\$ 9,116,200$ 
TABLE A-3.2. Palmer, Michigan Effluent Control Buildings and Equipment for Refinery

\section{Equipment}

1 - 10,000 CFM Baghouse Filter

1 - 16,000 CFM Venturi Scrubber

1 - 3,000 CFM Baghouse Filter

Total

Field Erection (14\% of PECC)

Foundations ( $12 \%$ of PECC)

Piping and Chuting (22\% of PECC)

Electrical (19.5\% of PECC)

Instrumentation ( $5 \%$ of PECC)

Miscellaneous Site Preparation (5\% of PECC)

Buildings ( $35 \%$ of PECC)

Service Facilities ( $55 \%$ of PECC)

Land $(6 \%$ of PECC)

Total Physical Cost

Engineering and Construction (25\% of TPC)

Direct Plant cost

Contractor's Fee

Total Plant Cost

Land

Total Buildings and Equipment Cost

\section{$\underline{\text { Cost }}$}

$\$ 16,500$

12,300

5,900

$\$ 34,700$

4,900

4,200

7,600

6,800

1,700

1,700

12,100

19,100

2,100

$\$ 94,900$

23,700

$\$ 118,600$

29,600

$\$ 148,200$

$-2,100$

$\$ 146,100$ 
TABLE A-3.3. Paimer, Michigan SuTfuric Acid Plant Buildings and Equipment Cost

Equipment

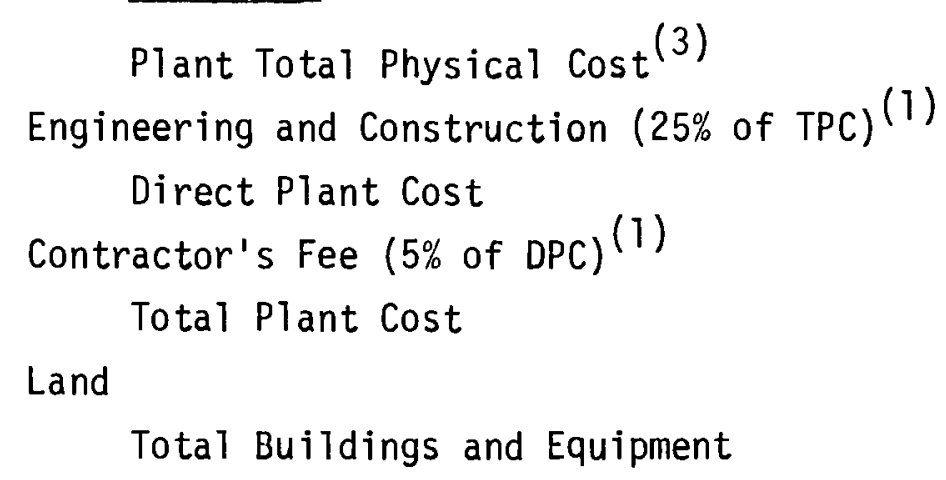

Plant Total Physical Cost ${ }^{(3)}$

Engineering and Construction (25\% of TPC) $(1)$

Direct Plant Cost

Contractor's Fee (5\% of DPC) ${ }^{(1)}$

Total Plant Cost

Land

Total Buildings and Equipment

Total Cost

$\$ 3,195,000$

436,700

$\$ 3,993,750$

109,200

$\$ 4,193,437$

$-70,091$

$\$ 4,123,000$ 
TABLE A-3.4. Palmer, Michigan: Byproduct Recovery Buildings and Equipment for Refinery

Equipment

2 - 30,000 gal. Agitated Tanks

1 - 3,000 sq. ft. Rotary Filter

2 - 20,000 gal. Agitated Tanks

1 - 1,500 sq. ft. Rotary Filter

1 - 500 sq. ft. Rotary Dryer

1 - Bag Packer

1 - 24,000 CFM Wet impingement Scrubber

Pumps

Materials Handling

Process Equipment Capital Cost

Field Erection (14\% of PECC)

Foundation ( $12 \%$ of PECC)

Piping and Chuting (22\% of PECC)

Electrical (19.5\% of PECC)

Instrumentation ( $5 \%$ of PECC)

Miscellaneous Site Preparation (5\% of PECC)

Buildings ( $35 \%$ of PECC)

Service Facilities ( $55 \%$ of PECC)

Land ( $6 \%$ of PECC)

Total Physical cost

Engineering and Construction (25\% of TPC)

Direct Plant Cost

Contractor's Fee ( $5 \%$ of DPC)

Total Plant Cost

Land
Total Cost

$\$ 276,000$

320,000

202,400

200,000

110,000

80,000

14,900

50,000

120,000

$\$ 1,373,300$

192,300

164,800

302,100

267,800

68,700

68,700

480,600

755,300

82,400

$\$ 3,756,000$

939,000
$\$ 4,695,000$

$\$ 4,695,000$

$\frac{234,700}{\$ 4,929,700}$

$-82,400$

$\$ 4,847,000$ 
APPENDIX B

FIXED CHARGE RATE 


\section{APPENDIX B}

\section{CALCULATION OF FIXED CHARGE RATES}

$i_{e}=$ Weighted average cost of equity as a fraction (preferred stock and common equity).

$i_{b}=$ Bond interest rate as a fraction.

b = Fraction of capital provided by bonds.

$k=$ State $\operatorname{tax}(1-$ Fed Tax $)+$ Fed Tax

$\mathrm{n}=$ Economic life of facility in years.

$v=$ Property tax rate.

$i=$ Effective cost of capital to the utility taking into consideration the tax credit for bond interest $=b \cdot i_{b}(1-k)+(1-b) i_{e}$.

crf = Capital recovery factor (level annual fraction of initial capital required to recover investment plus interest $)=\frac{i(1+i)^{n}}{(1+i) n-1}$.

pwf $=$ Uniform series present worth factor $=1 / \mathrm{crf}$.

tcf = Tax credit factor (level annual fraction for depreciation credit equivalent to a sum-of-years digits depreciation schedule).

$$
=\frac{2}{N(n+1) i} \quad\left[\frac{n}{p w f}-1\right]
$$

$f c=$ Fixed charges to recover investment, pay taxes, pay bond interest and return on equity

$$
=c r f+\frac{k}{(T-K)} \quad[c r f-t c f]
$$

$\operatorname{tax}=$ Level annual income taxes

$$
=k\left(f c-b \cdot i_{b}-t c f\right) \text {. }
$$

sf = Sinking fund (level annual fraction of capital which, when reinvested at rate $i$, produces the original investment after $n$ years)

$$
=\frac{1}{(1+i)^{n}-1}
$$


$p \cdot \operatorname{tax}=$ Level annual property tax equivalent to tax on depreciated investment using straight line depreciation

$$
=V\left[1-\frac{1}{n}\left(\frac{1}{i}-\frac{n}{(1+i)^{n}-1}\right)\right]
$$

Total fixed charges are the sum of the following items:

Interest on Bonds $\left(i_{b} \cdot b\right)$

Return on Equity $\left[i_{c} \cdot(1-b)\right]$

Recovery of Capital (sf)

Federal and State Income Taxes (tax)

Property Tax (p.tax)

Property Insurance Allowance

Interim Replacements Allowance

State Revenue Tax (Sum of above $\div(1$ - Revenue Tax Rate)) 
APPENDIX C

EFFECT OF URANIUM DECAY DAUGHTER

(Th-230) ON THORIUM RECOVERY 


\section{SUMMARY}

In ores containing both thorium and uranium, the economic effect of a decay product of uranium, Th-230, has been questioned in thorium-232 reactor fuel. U-232 is formed by irradiation of Th-230 and decays into daughter products emitting penetrating gamma radiation. Thus, U-233 fuel containing U-232 in great enough concentration must be remotely fabricated. Utilizing thorium containing essentially zero Th-230 has been hypothesized as a means of controlling U-232. However, studies accomplished using the ORIGEN ${ }^{(1)}$ code indicate that $n, 2 n$ reactions of neutrons with Th-232 also produce significant quantities of U-232. Thus, remote fabrications of U-233 will be necessary regardless of the Th-230 content of the $\mathrm{ThO}_{2}$ reactor fuel unless current reactor design or operating procedure is modified. Since the effectiveness of these modifications is questionable, no extra economic considerations are warranted in regard to Th-230 level for ores in this study. 


\section{INTRODUCTION}

Thorium is a valuable source of fertile material. Thorium by itself is not fissionable, but when natural thorium (Th-232) is irradiated, the fissile isotope U-233 is formed. U-233 is then separated from the thorium and fabricated into nuclear fuel. The thorium is either regenerated and returned to the reactor for further irradiation or discarded.

Fabrication of the U-233 may have to be conducted remotely because of the presence of the isotope $\mathrm{U}-232$ which has daughter products emitting high energy gamma rays. U-232 is mainly attributed to the presence of thorium230 in the original thorium-232 fuel. Th-230, in turn, is derived from the decay of uranium contained in some thorium-bearing ores.

The purpose of this report is to determine whether the presence of Th-230 in natural thorium will warrant special economic considerations. The report discusses: (1) when thorium-230 will be present in thorium reactor fuel, (2) the relationship between $T h-230$ and $\mathrm{U}-232$, and (3) the importance of Th-230 in the formation of $\mathrm{U}-232$ inside the reactor. The above information will then be related to the ores in this study and also compared to ores containing large quantities of Th-230. Finally, possible alternatives which affect the results of this study will be discussed. 
Occurrence of Th-230

Naturally occurring Thorium-230 is present in thorium ores associated with uranium. Uranium decays into Thorium-230 by the following reaction:

$\mathrm{U}-238 \frac{\alpha}{4.5 \times 10^{9} y}-\mathrm{Th}-234 \frac{\beta}{24 \mathrm{~d}}-\mathrm{Pa}-234 \frac{\beta}{6.7 \mathrm{~h}}-\mathrm{U}-234 \frac{\alpha}{2.5 \times 10^{5} y}-\mathrm{Th}-230$

Thorium wil1 thus be present in natural thorium (Th-232) uranium ore mixtures at some equilibrium concentration. Since Th-232 and Th-230 are chemical isomers, they cannot be chemically separated and the refined $\mathrm{ThO}_{2}$ will be a mixture of both isotopes.

Th-230 concentrations in Th-232 for ores in this study can be computed assuming the uranium equilibrium concentration of $18 \mathrm{ug} \mathrm{Th}-230 / \mathrm{gu}^{(2)}$. The thorium to uranium ratio of the ore is then estimated for different thorium deposits. Table C.1 illustrates the various concentrations of Th-230 in Th-232 for several thorium-containing ores. The Th-230 concentration varies from negligible to $60 \mathrm{ppm}$.

\section{Relationship Between Th-230 and U-232}

When thorium oxide containing Th-230 is irradiated, U-233 and U-232 are formed by the following reactions:

$$
\begin{aligned}
& \text { Th-232 } \frac{\mathrm{n}, \mathrm{y}}{\longrightarrow} \mathrm{Th}-233 \frac{\beta}{23 \mathrm{~min} .} \mathrm{Pa}-233 \frac{\beta}{27.4 \mathrm{~d}}-\mathrm{U}-233 \\
& \text { Th-230 } \mathrm{n,y}=\mathrm{Th}-231 \frac{\beta}{25.5 \mathrm{~h}} \mathrm{~Pa}-231 \mathrm{n,y}-\mathrm{Pa}-232 \frac{\beta}{1.31 \mathrm{~d}}-\mathrm{U}-232
\end{aligned}
$$

$\mathrm{U}-233$ is a long-life fissile isotope of uranium and utilized as a reactor fue1. U-232 is a useless activation product which in itself is not detrimenta1. However, U-232 decays into a series of short-1ived daughter products, some of which emit penetrating gamma radiation. Thus, after U-233 and U-232 are chemically separated from irradiated thorium, the U-232 decay products gradualiy build up in gamma activity. As a result, fabrication either has to be carried out quickly or will have to be conducted remotely ${ }^{(3)}$. 
TABLE C.1. Th-230 Content in Domestic Ores

\begin{tabular}{lcc}
\multicolumn{1}{l}{ Source } & $\frac{T h}{U}$ & $\frac{u g T h-230}{g T h-232}$ \\
Thorite (Lemhi Pass) & $\frac{100^{\mathrm{b}}}{1}$ & $.17^{\mathrm{a}}$ \\
Granite & $\frac{15^{\mathrm{c}}}{4}$ & 4.8 \\
Placer Monazite & $\frac{23^{\mathrm{d}}}{1}$ & .77 \\
Conglomerate Monazite & $\frac{23^{\mathrm{e}}}{1}$ & .77
\end{tabular}

(a) Analys is by C. A. Rohrman from personal communication between J. E. Minor, and E. R. Astley, Exxon Nuclear, Feb. 17, 1976.

(b) Francis J. Kelly, Technological and Economic Problems of Rare-Earth Metal and Thorium Resources in Colorado, New Mexico, and Hyoming. Information circular 8124, United States Department of Interior-Bureau of Mines, Update 1976 , p. 18.

(c) Nishimori, Richard K., et al., Uranium Deposits in Granitic Rocks, A report to the Energy Research and Development Administration, January, 1977, p. 7 .

(d) Cutbert, Thorium Production Technology, Addison-Wesley Publ. Co., Inc., Reading, Mass., 1958, p. 53.

(e) S. R. Borrowman and J. B. Rosenbaum, Recovery of Thorium from A Wyoming Ore, USBM Inf. report 5916, 1961.

\section{Importance of Th-230 in U-232 Formation}

As shown in the previous paragraph, irradiation of Th-230 results in the formation of $U-232$, but $U-232$ is also formed in reactor fuels as follows:
1. Th-232 $\stackrel{n, 2 n}{\longrightarrow} T h-23$

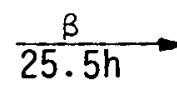
$\mathrm{Pa}-231 \stackrel{\mathrm{n}, \mathrm{\gamma}}{\longrightarrow} \mathrm{Pa}-232$
$1.32 d-B$
U-232

2. U-233 $\stackrel{n, 2 n}{\longrightarrow} U-232$

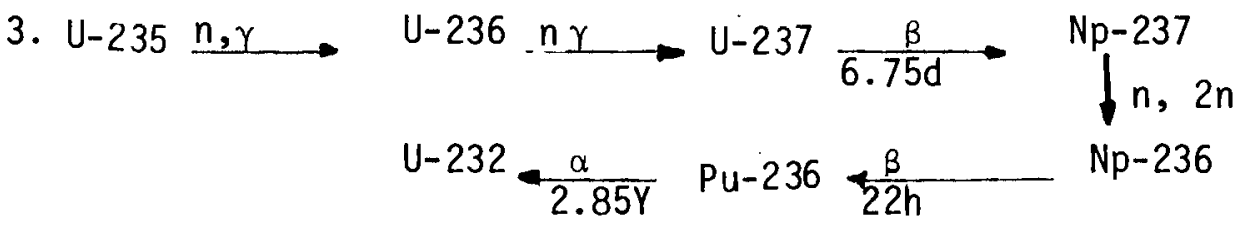


Assuming the above reactions form only negligible U-232, utilization of thorium with low Th-230 content will limit the formation of U-232. Thus, the higher costs associated with remote fabrication could be avoided by using fuel with a negligible Th-230 content.

To estimate the importance of $\mathrm{Th}-230$ in the formation of $\mathrm{U}-232$, a sensitivity analysis was conducted using the ORIGEN computer code. ${ }^{(1)}$ The calculation is based on a typical LWR cell of $\mathrm{UO}_{2}$ fuel design, a goal exposure of $33,000 \mathrm{MWD} / \mathrm{t}$, and one year of post irradiation cooling. The results are shown as follows:

Recoverable ${ }^{232} U$ for various ${ }^{230}$ Th concentrations

\begin{tabular}{cc}
$\mathrm{ppm}^{230} \mathrm{Th} \mathrm{in}{ }^{232} \mathrm{Th}$ & $\begin{array}{c}\text { Grams per ton } \\
\text { Uranium Enrich }\end{array}$ \\
\hline 1000 & 133 \\
100 & 30.6 \\
10 & 20.5 \\
0 & 19.3 \\
$0^{\star}$ & 0.234
\end{tabular}

${ }^{*} \mathrm{Th}^{232}$ cross section for the $\mathrm{n}, 2 \mathrm{n}$ reaction set to zero.

The results indicate that even with no Th-230 in the reactor fuel, $19.3 \mathrm{~g}$ U-232 will be present in recoverable uranium per ton of thoria fuel. Assuming approximately 34,500 grams of recoverable uranium per ton initial heavy metal, approximately $560 \mathrm{ppm}$ of U-232 will be present in the discharged uranium. Multiplying this by $3.84 \mathrm{mR} / \mathrm{hr} / \mathrm{ppm}^{(4)}$ gives a dose rate of $2.15 \mathrm{R} / \mathrm{hr}$. An acceptable dose rate for restricted personnel working $40 \mathrm{hrs} /$ week is $2.9 \mathrm{mR} / \mathrm{hr}$ according to 10 CFR 20. Thus, remote fabrication will be required for even very low Th-230 content of the original thorium. In addition, the U-232 resulting from a hypothetical fuel containing Th-232 with a zero $n, 2 n$ crosssection is almost negligible. Therefore, much of the U-232 in recoverable U233 results from $(n, 2 n)$ reactions on the $T h-232$. 
Thus, it appears that for current thermal reactor designs, remote fabrication will be necessary and no premium is warranted for ore with low Th-230 content.

\section{Effect of High Th-230 Concentrations}

For ores in this study, Th-230 content in Th-232 ranges from almost zero to approximately $5 \mathrm{ppm}$ (Table C.1). According to Battelle's analysis, the thorium-230 content of these ores warrants little concern. Even for ores containing 1000 ppm Th-230 in Th-232, only a 7-fold increase in U-232 content in recoverable uranium is realized. According to data calculated at Battelle, a ten-fold increase in dose will require only an additional $1 \mathrm{ft}$. of concrete shielding.

Extremely high Th-230 concentrations must be avoided, however. In the case of residues from typical uranium ore mills, $\mathrm{Th}^{230}$ in total thorium range from $.08-3.7 \%(1)$. Th-230 ranges of this nature would not only pose increased shielding requirements, but the dilution of Th-232 would result in lower reactor conversion ratios. As mentioned previously, ores in this study contain significantly lower Th-230 in Th-232 concentrations.

\section{Possible Uses of Th-230 Free Fuel}

Modifications to current fuel cell design have been proposed which limit $n, 2 n$ reactions with $T h-232$ and the formation of $T h-230$. An example of a proposed method is as follows: The thorium charges can be loaded in zones separate from the fissile fuel zone. This, in turn, reduces the amount of fast neutron flux in the thorium zone. Since fast neutrons (6 MeV) result in $n, 2 n$ reactions with $T h-232$, reducing the fast neutron flux reduces the formation of U-232. Unfortunately, the thermal neutron flux is also decreased and consequently a lower $\mathrm{U}-233$ conversion ratio results.

The goal exposure of the thoria fuel can also be reduced. Currently, a burn-up of 30,000 MWD/ton for an LWR cell can be assumed. If we reduce this exposure by one-third to 10,000 MWD/ton, approximately one-third the U-233 will be bred inside the reactor. However, the formation of U-232 is dependent on two neutron captures and varies exponentially with time to approximately the second power. Thus, reducing the exposure by one-third will reduce U-232 formation by one-ninth. 
If these methods prove to be adequate, Th-230-free fuel might be advantageous. However, the economic considerations of higher reactor operation costs vs. higher fabrication costs would have to be analyzed and is beyond the scope of this report. 


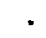




\section{REFERENCES}

1. M. J. Be11, ORIGEN--The ORNL Isotope Generation and Depletion Code, ORNL-4628, Oak Ridge NationaT Laboratory, Oak Ridge, Tennessee, May 1973.

2. C. A. Rohrmann, Special Radioisotopes for Power: Availability and Applications of Thorium-230 (Ionium) from Uranium Ore Mi11s. HW 71319 (REV), Report for AEC Research and Development by General Electric, Hanford Atomics Produces Operation, Richland, WA 99352, October 16, 1961.

3. B. Prakesh, S. R. Kanton and N. K. Rao, Metallurgy of Thorium, IAEA, Vienna, p. 52, 1952.

4. Assessment of Thorium Fuel Cycles in Pressurized Water Reactors--Final Report, EPRI-NP-359, Combustion Engineering, Inc., February 1977. 


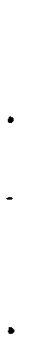


APPENDIX D

LEMHI PASS MODEL MINE

This a ppendix is a report completed for PNL by a consulting agency. 


\title{
Golder Associates
}

CONSULTING MINING AND GEOTECHNICAL ENGINEERS

\author{
REPORT TO \\ BATTELLE-PACIFIC NORTHWEST LABORATORIES \\ FOR \\ MINING THORIUM-BEARING VEINS \\ AT LEMHI PASS \\ BY UNDERGROUND MINING METHODS
}

Distribution:

3 copies - Battelle-Pacific Northwest Laboratories

3 copies - Golder Associates, Inc.

S78008

June 1978 


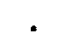


1.0 INTRODUCTION

2.0 SUMMARY

2.1 Description of the Lemhi Pass Area

2.2 Geological Information

2.3 Hypothetical Orebody

2.4 Conceptual Mining Methods

2.5 Project Costs

3.0 DESCRIPTION OF THE LEMHI PASS AREA

3.1 Location

3.2 Geography

3.3 Climate

3.4 Environmental Considerations

4.0 GEOLOGICAL INFORMATION

4.1 Geological Setting

4.2 structure

4.3 Mineral Deposits

4.3.1 Dimensions and Attitudes of Veins

4.4 Geotechnical Data

4.5 Proposed Exploration Program

5 .0 HYPOTHETICAL OREBODY MODEL

6 .0 CONCEP'TUAL MINING METHODS

6.1 Resuing

6.2 Cut and Fill

6.2.1 Backfill System

6.3 Overall Mine Design

7.0 PRO.JLCT cosTS

7.1 Exploration and Prerevenue Lxpenditure

7.2 Operating Costs

7.3 Capital Costs

7.4 Upper and Lower Bound Costs 


\section{REFERE'NCLS}

\section{APPENDIX}

A.1 Diamond Drilling

A.2 Resue Stoping

A.3 Cut and Fill Stoping

A. 4 Backfill System

A.5 Ore Reserves

A.6 Development and Construction

A. 7 Operating Costs

A. 8 Capital Costs 


\section{LISI OF' TABLLS}

1. Dimensions and attitudes of some of the thorium-boaring veins in the Iemhi Pass Area.

2. Manpower requirements and costs at 250,000 tons per year (250 days).

3. Estimated exploration and prerevenue expenditures.

4. Prerevenue development.

5. Estimated operating costs to produce 1,750,000 tons, year 1 to 7 inclusive.

6. Estimated operating costs to produce 1,794,000 tons, year 8 to 14.1 .8 inclusive.

7. Estimated capital expenditure and annual depreciation.

8. Summary of upper and lower bound and estimated project costs.

9. Effect of a variation in mine grade on the cost of $\mathrm{ThO}_{2}$.

10. Effect of a variation in vein width on the cost of $\mathrm{IhO}_{2}$.

11. Effect of a variation in mining reserve on the cost of $\mathrm{ThO}_{2}$.

A1 Estimated cost of resue stoping .

A2 Estimated cost of cut and fill stoping.

A3 Estimated costs of sandfill.

A4 Summary of hypothetical ore and mining reserves.

A5 Determination of development and construction quantities.

A6 Summary of development and construction quantities.

A7 Estimated costs of development.

A 8 Estimated costs of construction.

A9 Summary of ventilation requirements.

A10 Ilaul distances and tonnage of Lower Blocks.

A11 Lstimated costs of rail haulage.

A12 Summary of compressed air requirements.

A13 Annual power costs.

A14 Operating costs of personnel and supplies transport.

A15 Hourly equipment costs.

A16 Indirect operating costs year 1 to 7 inclusive.

A17 Indirect operating costs year 8 to 14.18 inclusive. 


\section{LIST OF FIGURES}

1. Index map of eastern Idaho and southwestern Montana, showing the location of the Lemhi Pass area.

2. A geological map and sections of the Lemhi Pass area, Lemhi County, Idaho, and Beaverhead County, Montana.

3. Idealized resue stope.

4. Idealized cut and fill stope.

5. Schematic flowsheet of the backfill system.

6. Production and development schedules, Lemhi Pass thorium deposits.

7. Exploration, prerevenue and development schedule.

8. Schedule of estimated annual operating, capital, replacement, depreciation and amortization costs.

A1 Idealized section of the Wonder Lode Vein.

A2 Idealized sections of the Lucky Strike Vein.

A3 Idealized sections of the Lucky Strike and Trapper Veins.

A4 Idealized sections of the Last Chance Vein. 


\section{$1.0 \quad$ INTRODUCTION}

This report complies with the request of Battelle-Northwest to investigate the cost of mining thorium-bearing veins by underground mining methods at Lemhi Pass, Idaho, as described in Consultant Agreement B-65327-A-L, Prime Contract EY-76-C-061830. It forms part of a thorium resource price analysis to provide the data needed for the fuel cycle economic studies under investigation by Savannah River Laboratory and Pacific Nor thwest Laboratories.

Thus, to furnish the necessary data, conceptual mining approaches for the underground working of the thorium deposits were postulated in conjunction with an estimate of their related capital and operating costs.

These estimates are based on an appropriate orebody model and various production parameters hypothesized from the limited geological information available. 


\subsection{SUMMARY}

\subsection{Description of the Lemhi Pass Area}

The Lemhi Pass area is situated in the east-central part of the Beaverhead Mountains along the Idaho-Montana border in the northwestern United States.

For the most part, the area is uninhabited, and the Beaverhead Mountains are a generally rugged, single-crested divide that trends southeast and separates the valley of the Lemhi River on the west from the Horse Prairie of the Beaverhead Valley on the east. Drainage has dissected the slopes of the range into a series of deep gorges and steep ridges that are heavily timbered on the north-facing slopes and also in shaded canyons. The district lies within the Salmon National Forest and will have to comply with the new environmental regulations.

\subsection{Geological Information}

The level of geological data available upon which to base an orebody model is low, and therefore any models developed must be regarded as hypothetical.

The major groups of rocks exposed in the Lemhi Pass area are fine-grained clastic sedimentary rocks (Precambrian Belt Supergroup), volcanic rocks (Tertiary Challis Volcanics) and unconsolidated deposits (Quaternary). These rocks have been folded and faulted and have been considerably disturbed a number of times. A generally low competence of the country rocks is indicated. 


\subsection{Hypothetical Orebody Mode 1}

The thorium-bearing veins are irregular siliceous replacement bodies formed along zones of shearing and faulting. The vein geometry is irregular but may be regarded as a tabular narrow body with a steep dip of about 60 degrees and a strike length from 50 feet to approximately 1,000 feet. Vein thicknesses are usually less than 5 feet but can be 10 feet and greater. Mineralization is also extremely variable with an overall mean for the district of 0.46 percent thorium.

\subsection{Conceptual Mining Methods}

Given the narrow veins, which dip steeply in rocks of low competence, two stoping methods are postulated; namely, the resue, and the cut and fill methods. Veins narrower than 5 feet are mined by resuing and veins of greater thickness by cut and fill methods.

\subsection{Project Costs}

The total cost of mining the thorium deposits at a production rate of 250,000 tons per year is $\$ 71,389,734$. Operating costs account for $\$ 63,781,234$ of this sum and capital expenditure amounts to $\$ 7.608,500$. The upper and lower bounds for the total project cost are $\$ 105,000,000$ and $\$ 64,400,000$ respectively.

\subsection{Major Uncertainties}

The major areas of uncertainty in this report which could affect the costs estimated, include geological data such as vein geometry and ore grade, ground conditions and the cost of stope fill. 


\subsection{DESCIIP'LION OF THE LEMIII PASS AREA}

The Lemhi Pass area lies astride the Continental Divide along the Idaho-Montana border in the northwestern United States (see Figure 1). This area represents a zone of abundant thorium-bearing veins.

\subsection{Location}

The major Part of the Lemhi Pass area is in Beaverhead County, Montana, and is sited approximately 40 miles southwest of Dillon, Montana. The remaining area is in Lemhi County, Idaho, and is some 25 miles southeast of Salmon, Idaho. The district lies between State Highway 28 to the west and Interstate Highway 15 to the east. An unimproved dirt road that crosses the northern part of the Lemhi Pass quadrangle connects these major highways. Roads and trails lead off from this county road and give access to most of the properties and old mine sites in the area. However, travel over some sections of these roads requires the use of four-wheel drive vehicles. To the east of the area a line of the Union Pacific Railroad runs along the east side of the Clark Canyon Reservoir, Montana.

Although, for the most part, the area is uninhabited, it is envisaged that future mining operations could be staffed from the populations of the outlying towns such as Salmon and Dillon.

\subsection{Geography}

The Beaverhead Mountains in this area are a generally rugged, single-crest divide that trends southeast and separates the valley of the Lemhi River on the west from the Horse Prairie of the Beaverhead Valley on the east. The range rises steeply from the flanking valleys to reach elevations in places of almost 

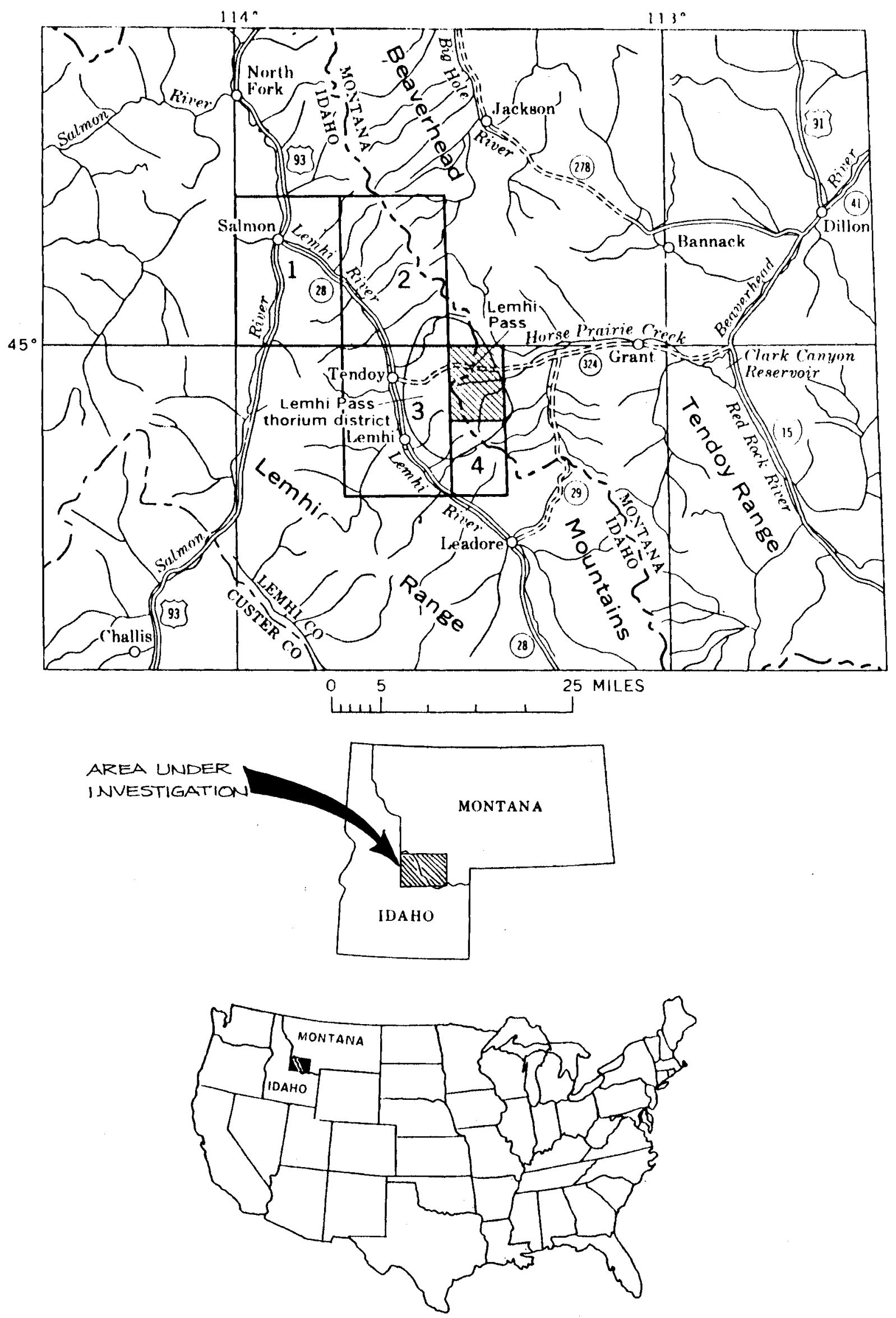
11,000 feet but at the Lemhi Pass an altitude of on $1 y 7,373$ feet is attained. In cross-section, the range is asymmetric with a generally irregular eastward slope that is less abrupt than the more unbroken front of the western slope (Figure 2). Thus, due east of Lemhi Pass the country is characterized by rolling barren hills. Glacial cirques are prominent on the east side of the crest of the divide which is broadly rounded and is almost park-like for several miles in the area of the broad shallow saddle of Lemhi Pass. However, the crest becomes more rugged as well as higher in altitude both to the south and north of the pass area.

Drainage has dissected the slopes of the range into a series of deep gorges and steep ridges that are heavily timbered on the north-facing slopes and also in shaded canyons. The general pattern of both open and forested areas is controlled by the amount of moisture obtained and held by the surficial soil, as well as by the rock type. In general, the area underlain by volcanic rocks is less forested than that underlain by other rocks. For example, the roughly triangular patch of volcanic rocks near the center of the area is for the most part unforested but is surrounded by forest-covered areas that are underlain by Belt rocks concealed by glacial till. Yellow pine, lodgepole pine, douglas fir, and aspen are the principal trees of the area; limber pines grow at places on the highest crest. Unforested areas are heavily covered with grasses and sparse amounts of sagebrush.

\subsection{Climate}

Snow is abundant from mid-October to mid-May with average accumulations of approximately 36 inches. During these fall, winter, and spring months the air temperature can drop to $-40^{\circ} \mathrm{F}$ but is more usually in the region of $45^{\circ} \mathrm{F}$. The summers are mild 


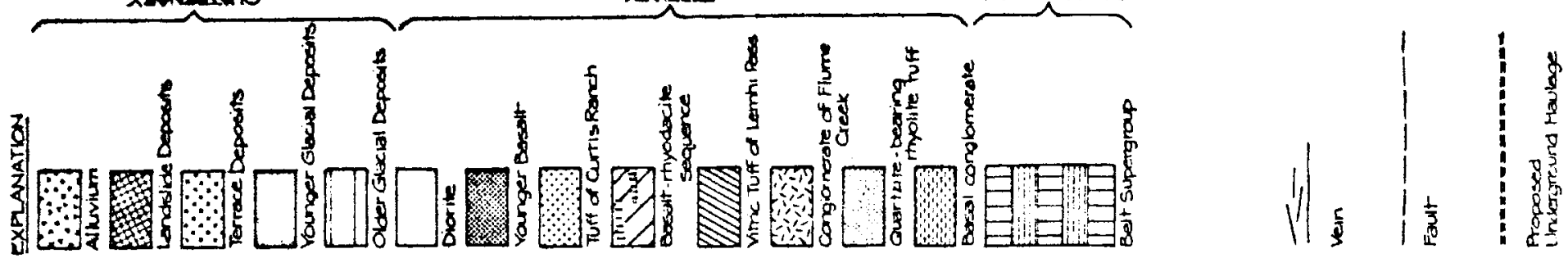
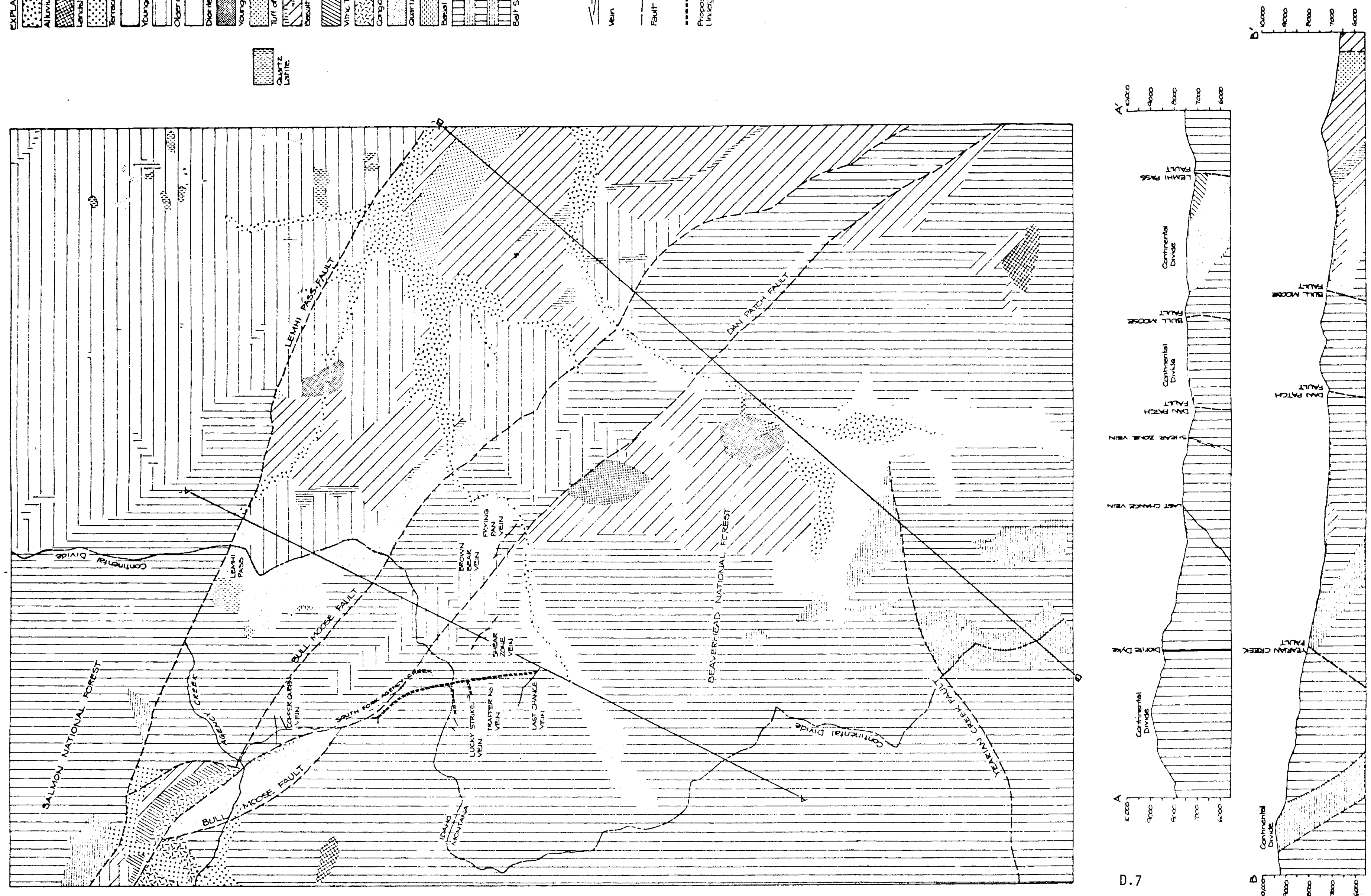

and occasional showers and thunderstorms provide sufficient moisture to maintain the flow of all the creeks and numerous springs. The average annual rainfall is about 18 inches.

\subsection{Environmental Considerations}

Future mining operations in the Lemhi Pass district, which lies within the Salmon National Forest, will have to comply with the new regulations that fall under the "Mineral Resources on National Forests Use Under U.S. Mining Laws, Title 36, Code of Federal Regulations, Part 252." However, as mining operations have been carried out previously in this area, the revival of operational activities will probably be considered as a minimal disturbance of the area. Thus it is unlikely that environmental considerations will be of major importance to the overall project cost. 
4.0 GEOLOGICAL INFORMATION

Previous geological work in the Lemhi Pass area dates back to 1804 when an expedition was commenced by Lewis and Clark (Sharp and Cavender, 1962). Exploration work has been sporadic since the initial investigation, apart from two periods of prospecting during which the geology of the area was further studied. Copper was the subject of the first period which started about 1883 and resulted in the discovery of the main vein in the Copper Queen, a small underground mine. The second period was initiated with the finding of thorium in the Lemhi Pass area in 1949. Prospecting activity has been maintained throughout this latter period with the emphasis on the search for radioactive minerals.

The greater part of the work on the thorium veins concentrated on their size, shape, and grade. These data were obtained by shallow bulldozer trenches, short adits (with the exception of the Last Chance vein), drifts, and three boreholes (Sharp and Cavender, 1962). Recovery from these boreholes was on the whole poor, being 51 percent (DDH1), 39 percent (DDH3), and 0 percent $(\mathrm{DDH} 4)$. Further, as the overburden is thick in many areas and outcrops are few, the position of contacts of the veins had to be inferred in many places. From this level of information it can be seen that any orebody model developed must at best only be regarded in a hypothetical light.

Of the reological studies (see references, this roport) which have beon carrled out in ho hemht Pusis aren over these: years, the most recent work of Sharp and Cavender (1962) and staatz (1972) is considered to be the most appropriate to this report. The former used aerial mapping and detailed mapping by plane table methods for the surface exposures and Brunton compass and tape for the underground mapping. In addition to 
some of these techniques for mapping the regional geology, Staatz (1972) in his detailed study of the mineralogy of the thorium veins, separated individual minerals by heavy liquids, magnetic separation, and hand picking. Minerals were then identified by $\mathrm{X}$-ray diffraction. All the known underground workings were also investigated by staatz for radioactivity with a scintillation counter.

\subsection{Geological Setting}

The major groups of rocks exposed in the Lemhi Pass area are fine grained clastic sedimentary rocks (Precambrian Belt Supergroup), volcanic rocks (Tertiary Challis Volcanics) and unconsolidated deposits (Quaternary), (Figure 2). The Precambrian Belt Supergroup consists principally of fine-grained micaceous quartzite, interbedded in places with siltite. These rocks underlie the entire district and are poorly exposed at the surface over about 60 percent of the area. With one exception, all veins in the Lemhi Pass area occur in rocks of the Belt Supergroup which probably at one time was entirely overlain by flows and tuffs of the Tertiary Challis Volcanics. These volcanic rocks were subsequently eroded and are now exposed in only about 15 percent of the area in downfaulted blocks and small erosional remnants (Figure 2). The consolidated Quaternary deposits that conceal the underlying rocks in about 25 percent of the area consist of older glacial deposits, river gravels, younger glacial deposits, terrace deposits, landslide deposits and alluvium.

Diorile dikes, of post-Challis age, are scatlered throughout the area. 


\subsection{Structure}

The Precambrian rocks in the Lemhi Pass area were folded and faulted by the forces that produced the Beaverhead Mountains and other ranges of east-central Idaho and southwest Montana. Tertiary rocks of the district are also folded and faulted but to a much lesser degree. So far as is known, the folds are small and the major structural features in the area are long and continuous forming wide broken-rock zones, but most of the faults appear to be relatively short and only a few feet wide (Figure 2). Many such faults that are present along the Continental Divide south of the pass trend principally north to northwest, but other faults in the same area have diverse trends. The faults all have steep to near-vertical dips.

The beds of the Belt series are generally thin, from 1 inch to a few feet, and mostly dip from about 20 to 50 degrees to the north. Minor folds are present, and more complex folding is suggested by some of the mapping data. A conspicuous fracture cleavage is present in the same beds which dips at a much lower angle than the Belt rocks.

The most prominent structural feature in the area is the zone of faulting called the Lemhi Pass fault which forms a zone 350 to 1,000 feet wide. The dip of these faults is, in general, to the south at 60 degrees or more.

In places, the bedded tuffs are inclined as much as 35 degrees which indicates considerable post-volcanic tilting in the area. The Tertiary lake beds along the flanks of the Beaverhead range in the Lemhi Pass area are generally inclined 20 to 25 degrees to the east. 


\subsection{Mineral Deposits}

The greater part of the mineralization in the area occurs in quartz veins and irregular siliceous replacement bodies that contain copper, gold, and thorium. Veins were noted by Staatz (1972) at 107 localities and, of these, 87 were found to contain thorium. Base and precious metals are present in some of the thorium deposits and in other veins of the district and along its border. However, only the Copper Queen mine and the Blue Bird mine near Agency Creek in Idaho have actually produced copper. The area is also known to contain several thousand tons of rare earths.

The veins were formed by fissure-filling and wall-rock replacement along zones of shearing and faulting in the micaceous quartzite of the Belt series. Recurrent movement along the faults has broken and sheared most of the vein material. The grade can therefore be expected to vary considerably within the veins. For example, the 14 samples taken from the Last Chance vein ranged from 0.074 percent to 1.7 percent, with a mean of 0.45 percent and a coefficient of variation of 106 percent. It is therefore evident that the many single samples recorded by staatz have very little meaning other than to confirm the presence of thorium.

\subsubsection{Dimensions and Attitudes of Veins}

Throughout the latest period of exploration the dimensions and attitudes of the outcrops of the numerous veins in the area have become better defined. For example, the length of the Last Chance vein exposed in 1952 was about 1,200 feet in comparison to its known length at the present time of approximately 3,900 feet. In order to produce a realistic model of the veins in the 
district for the purposes of doveloping concoptual mining methods, several of the veins have been studied. Dimensions of these veins, as detailed by staatz, are given in Table 1. 
TABLE 1

DIMENSIONS AND ATTITUDES OF SOME OF THE THORIUM-BEARING VEINS IN THE LEMHI PASS AREA

\begin{tabular}{|c|c|c|c|c|}
\hline Vein & $\begin{array}{l}\text { Exposed } \\
\text { Length } \\
\text { (feet) }\end{array}$ & $\begin{array}{c}\text { Thickness } \\
\text { (feet) }\end{array}$ & Strike & Dip \\
\hline Lucky Horseshoe & 1,400 & $0.8-1.5$ & $\mathrm{~N} 67^{\circ} \mathrm{W}$ & $70^{\circ} \mathrm{NE}$ \\
\hline Betty Jo & 425 & 1.0 & $\mathrm{~N} 35^{\circ} \mathrm{E}$ & $20^{\circ} \mathrm{NW}$ \\
\hline Buffalo & 250 & $2.0-11.0$ & $N 5^{\circ}-27^{\circ} \mathrm{W}$ & $60^{\circ} \mathrm{SW}$ \\
\hline Deer Fraction & 60 & $2.0-3.0$ & $\mathrm{~N} 72^{\circ} \mathrm{W}$ & $70^{\circ} \mathrm{SW}$ \\
\hline Deer & 250 & 2.0 & $\mathrm{~N} 67^{\circ} \mathrm{W}$ & $*$ \\
\hline Wonder & 1,200 & $1.0-10.0$ & $\mathrm{E}-\mathrm{W}$ & $40^{\circ}-89^{\circ} \mathrm{S}$ \\
\hline Cago No. 12 & 2,800 & $0.3-13$ & $\mathrm{~N} 55^{\circ} \mathrm{W}$ & $46^{\circ}-48^{\circ} \mathrm{S}$ \\
\hline Cago No. 10 & 100 & 1.3 & $\mathrm{~N} 45^{\circ} \mathrm{W}$ & Steep W \\
\hline Contact & 1,950 & $0.7-10.0$ & $\mathrm{~N} 70^{\circ} \mathrm{E}$ & $26^{\circ}-56^{\circ} \mathrm{S}$ \\
\hline East Vein & 60 & +3.0 & $\mathrm{~N} 39^{\circ} \mathrm{W}$ & Steeply \\
\hline West Vein & 50 & 4.5 & $\mathrm{~N} 30^{\circ} \mathrm{E}$ & $40^{\circ} \mathrm{NW}$ \\
\hline Beaverhead & 525 & $2.0-4.0$ & $\mathrm{~N} 85^{\circ} \mathrm{E}$ & $40^{\circ} \mathrm{S}$ \\
\hline Trapper No. 1 & 235 & $5.0-11.0$ & $\mathrm{~N} 75^{\circ}-85^{\circ} \mathrm{N}$ & $45^{\circ}-60^{\circ} \mathrm{S}$ \\
\hline Wonder East Vein & 100 & $1.5-2.0$ & $\mathrm{~N} 38^{\circ} \mathrm{W}$ & $30^{\circ} \mathrm{SW}$ \\
\hline Little Dandy No. 1 & 90 & 2.5 & $\mathrm{~N} 75^{\circ} \mathrm{W}$ & $80^{\circ} \mathrm{NE}$ \\
\hline Shear Zone & 6,000 & $0.5-2.5$ & $\mathrm{~N} 55^{\circ} \mathrm{W}$ & $65^{\circ}-81^{\circ} \mathrm{SW}$ \\
\hline Black Rock & 1,630 & $2.0-6.0$ & $\mathrm{~N} 47^{\circ} \mathrm{W}$ & $70^{\circ} \mathrm{W}$ \\
\hline Last Chance & 3,900 & $7.0-30.0$ & $\mathrm{~N} 65^{\circ}-80^{\circ} \mathrm{W}$ & $43^{\circ}-70^{\circ} \mathrm{SW}$ \\
\hline Frying Pan West & 100 & 3.0 & $\mathrm{~N} 30^{\circ} \mathrm{W}$ & $54^{\circ} \mathrm{SW}$ \\
\hline Frying Pan Southeast & 1,100 & $0.5-0.7$ & $\mathrm{~N} 36^{\circ}-73^{\circ} \mathrm{W}$ & $72^{\circ}-78^{\circ} \mathrm{SW}$ \\
\hline $\mathrm{G} \& \mathrm{G}$ No. $6 \& 8$ & 1,300 & $1.0-2.0$ & $\mathrm{~N} 48^{\circ} \mathrm{W}$ & Stecp \\
\hline $\mathrm{G} \& \mathrm{G}$ No. 1 \& 2 & 1,600 & $0.8-2.0$ & $\mathrm{~N} 48^{\circ} \mathrm{W}$ & $58^{\circ} \mathrm{SW}$ \\
\hline Thorite No. 1 & 300 & 0.9 & $\mathrm{~N} 45^{\circ} \mathrm{W}$ & $85^{\circ} \mathrm{NE}$ \\
\hline Dan Patch & 1,050 & $0.3-2.5$ & $\mathrm{~N} 77^{\circ} \mathrm{W}$ & $60^{\circ}-80^{\circ} \mathrm{SW}$ \\
\hline Reactor & 1,650 & $0.3-3.0$ & $\mathrm{~N} 42^{\circ} \mathrm{W}$ & $72^{\circ} \mathrm{SW}-78^{\circ} \mathrm{NE}$ \\
\hline
\end{tabular}

* Not determined. 
It is evident from Table 1 that the thorium-bearing veins are irregular tabular bodies ranging in thickness from less than 1 foot to 30 feet. About 50 percent of the known veins average more than 1 foot thick and about 12 percent are more than 5 feet thick. The thickest vein is the Last Chance which is from 7 to 30 feet thick. Several other veins are as much as 10 feet thick. Most veins are extremely variable in thickness, but a few are fairly uniform. For instance, the Reactor vein ranges in thickn from 1.5 to 2.0 feet for at least 975 feet of its strike length.

The majority of the thorium-bearing veins strike $\mathrm{N} 40^{\circ}-50^{\circ} \mathrm{W}$ or $\mathrm{N} 70^{\circ}-80^{\circ} \mathrm{W}$, although almost every direction except due north is represented. Strike on individual veins commonly varies, but these variations are more apparent on the larger veins. Most of the veins dip steeply to the southwest, but may dip moderately to steeply either to the north or south.

\subsection{Geotechnical Data}

Based on the very scant information available to date, only the broadest of assumptions can be made with regard to the characteristics of the rock mass in the Lemhi Pass area. It is apparent that the rocks in the area have been disturbed a number of times, and a moderately complex structure exists, probably in conjunction with residual stresses. However, the regional stress field is unlikely to have an overriding adverse effect on mining operations at the shallow depths envisaged.

The effect of the many joints and fractures on the rock mass quality are of great importance to operations and their viability. The data obtained from the three boreholes drilled through the hangingwa11, orebody and footwall of the Last Chance 
vein indicates the generally low competence of the country rocks. For example, the Wonder Lode vein lies in a zone of faulting that affects not only the entire vein along its exposed length, but also the country rock for as much as 100 feet on either side (Sharp and Cavender, 1962). It is therefore likely that considerable support problems could arise in both stopes and associated excavations. This situation could be considerably worsened by the presence of an excessive level of groundwater, particularly in the vicinity of major faults. There is little evidence at this date, however, to suggest that such levels of groundwater exist.

\subsection{Proposed Exploration Program}

To the best of our knowledge, no systematic exploration program has been carried out in the Lemhi Pass area to substantiate the existence of economic deposits of thorium. On the other hand, the information available indicates, that owing to the methods of exploration used, it is quite possible that many veins remain undiscovered. In addition to these factors, geotechnical data must be compiled to better assess the in-situ ground and water conditions. It is therefore imperative that a substantial exploration program is initiated prior to commencement of any mining operation.

The drilling required to prove as orebodies the six veins selected for mining cost purposes in this report, is a minimum of 70,000 feet of "NX" diameter diamond drill core. This figure is based on vertical geological sections at 100-foot centers and intersecting the veins at 250-foot vertical intervals, with holes inclined at -60 degrees to the horizontal (see Appendix A1). A minimum period of two years would be required for the 
drilling and data collection program, given reasonable weather conditions.

D. 18 
5.0 IYYOTIE'ICAL OREBODY MODEL

A hypothetical model of the likely orebodies can be described as follows:

Deposit Type: Quartz veins and irregular siliceous replacement bodies formed by fissure filling and wall rock replacement along zones of shearing and faulting.

Geometry: Irregular tabular narrow bodies subdivided into veins less than 5 feet wide and veins greater than fivefeet wide. Strike length ranges upwards from 50 feet with some 12 veins greater than 1,000 feet long. The inclination of both vein classes can be regarded as steep, with an average dip of approximately 60 degrees. The depth of one vein has been established at about 250 feet below surface.

Grade: Mineralization within the veins is extremely variable. The mean grade of the Last Chance vein is 0.47 percent $\mathrm{ThO}_{2}$ which compares with an overall mean for the district of 0.46 percent $\mathrm{ThO}_{2}$.

Ground Conditions: Overall a poor rock mass quality of both orebody and country rocks. Stopes and associated tunnels will probably require support.

Water Conditions: Little likelihood of an excessive level of groundwater. 
6.0 CONCEPTUAL MINING METHODS

Two mining methods are indicated from the hypothetical orebody model. These are the resue and the cut and fill mining techniques. The resue method is suitable for the extraction of the veins less than 5 feet thick, and the cut and fill technique will satisfy the constraints on mining of the veins greater than 5 feet thick. The stope walls are supported in both methods which, owing to their probable weakness, is a prime consideration for the satisfactory removal of the veins. A distinct advantage of each method is that most of the likely variations in the dip, strike and continuity of the veins can, to a large extent, be included within the boundaries of stopes. The major disadvantages of both methods are economic, in that operating costs are usually high, coupled with low productivities owing to the limited possibilities for mechanization.

\subsection{Resuing}

Resue mining has generally been used to work very narrow high-grade veins, but its use has diminished over the years. The ore grade and thickness are limiting factors in resuing, since a narrow vein must bear the cost of handling a much greater quantity of waste rock. Another requirement of this method is a well-defined plane of weakness along the contact of the vein and country rock to ensure that the ore and waste can be worked separately with a minimum of dilution. The vein-wall rock contacts at Lembi Pass are generally sheared.

The sequence of mining resue stopes necessitates the opening of a flat-back overhand stope of minimum width alongside a portion of the narrow vein (Figure 3 ). The broken waste is 

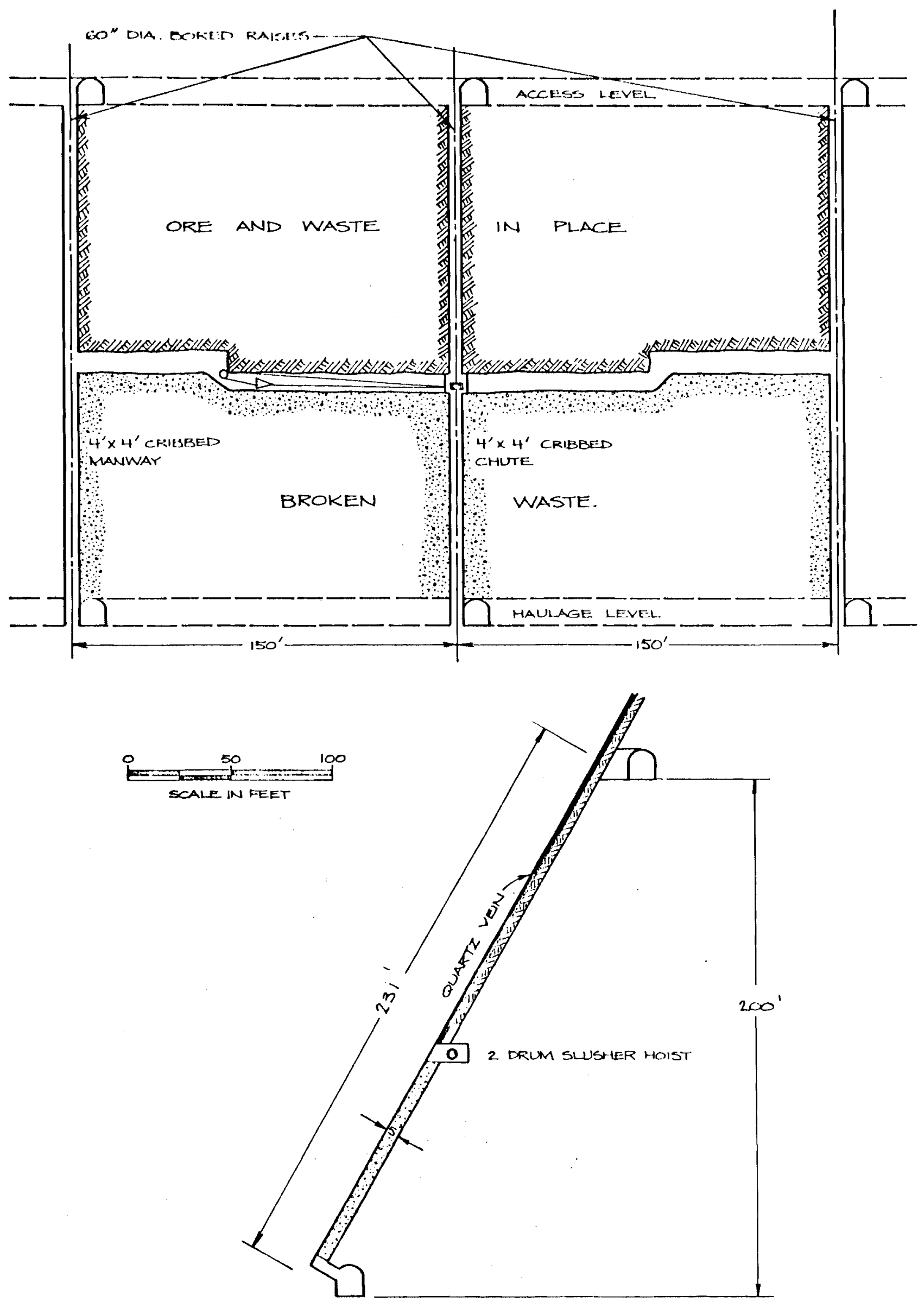
used to fill the stope for support of the hangingwall and to provide a working base for mining the narrow vein. The broken ore is delivered, probably by scraping, into ore chutes, which are carried through the waste fill. These chutes are extended from the haulage below as mining progresses towards the upper access level.

The layout proposed for the narrow veins at Lemhi Pass is based on 5 feet thick by 300-feet long by 31-feet down dip stopes (Figure 3). Five-foot diameter machine-bored raises are placed in the plane of the vein on 150-foot centers along strike. These raises are utilized for manways, ventilation and ore chutes. Access and haulage levels are situated in the footwall of the veins and are not, as is more usual, developed along the vein. This is done to avoid possible accumulations of radon gas and to seek more competent rock. Proximity of these drifts to veins will be controlled by geotechnical and practical considerations.

Two drum slusher hoists, placed in the center of the stopes, are able to clean either side of a stope to permit a sound operational cycle. A productivity of 4.5 tons per man shift is expected with this method from a two-man crew, based on mucking 34 tons per drilling shift. This rate compares with 25.8 tons mucked per drilling shift in a resue stope at the Tayoltita Mine (Haptonsta11, 1978). Assumptions made to determine the expected productivity are enumerated in Appendix A2.

\subsection{Cut and Fil1}

Cut and fill stoping is a suitable method for the extraction of steeply dipping veins greater than 5 feet thick. 
Costs estimated for this method have been based on a 10-foot thick vein (see Appendix A3). This technique is currently practiced in one form or another throughout the world. One of the most important aspects of cut and fill stoping, both economically and practically, is the design and implementation of the filling system.

As in resuing, stoping commences from the haulage level and progresses upward. Ore is usually removed in horizontal slices in overhand stopes and delivered to an ore chute which connects to the haulage level below. On completion of each cut, fill is distributed throughout the stope and so provides both support to the hangingwall and a working platform for the next cut.

The design of cut and fill stopes for the Lembi Pass employs a central 6 foot by 8 foot two-compartment raise (Figure 4). This raise, divided into an ore chute and service compartment, connects the haulage and access levels, which are 200 feet apart, vertically. The assumed stope length of 300 feet along strike could alter, depending upon varations in the strike length and width of the vein.

An air-operated loader is used in the stope to haul the broken ore to the central ore chute. For stopes less than 10 feet wide, a slusher would be utilized. It is estimated that a three-man crew can produce at a rate of 116 tons per shift.

\subsubsection{Backfi11 System}

It is intended to obtain fill material from adjacent Quaternary deposits as opposed to using deslimed mill tailings, which have a potential for releasing radon gas into the mine airstream. Thus, the fill material is a high-cost item, 

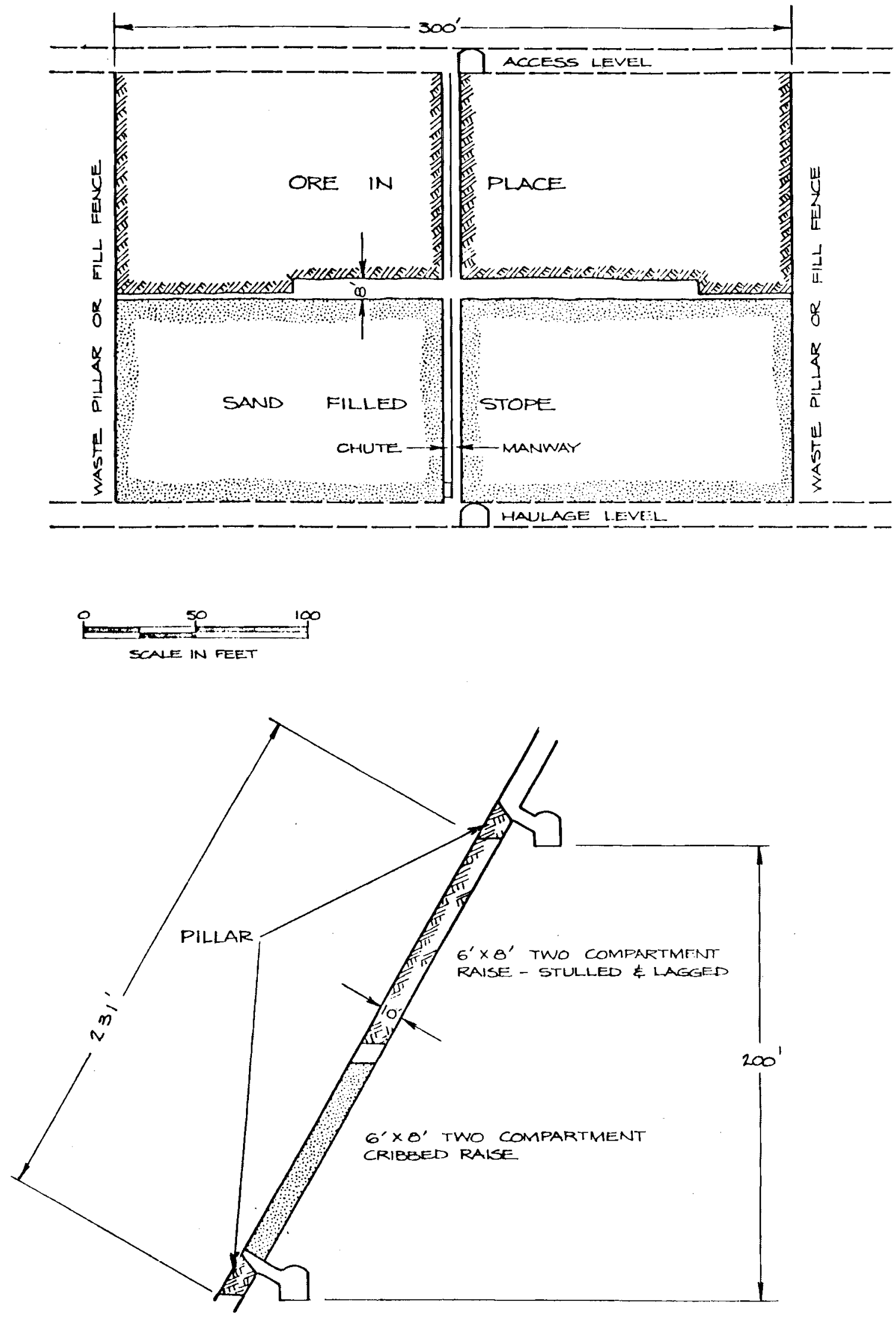
particularly if the handling problems expected in cold weather are considered. It has been assumed that sand is delivered to the mine site by a subcontractor at a cost of $\$ 5.00$ per cubic yard, including stripping the sand deposit, mining, reclamation, hauling, processing, royalties, and protection of the sand during cold weather. Processing of the sand at the mine site involves screening off the plus 1/8-inch fraction and would also include removal of any clay materials.

The fill system envisaged consists of a water tank, agitator tank, cement hopper and, for the lower blocks, a 5 foot diameter bored storage raise (Figure 5). For the upper blocks, sand is conveyed to an agitator tank where it is mixed with water to form a 60 percent solids slurry. Sufficient water for this system could be pumped from the local streams. From the agitator, hydraulic fill passes to the stopes through a 3 inch diameter borehole and pipe system. For the lower blocks, the slurry would be mixed underground adjacent to the storage raise. The final 6 inches of each fill lift would consist of a sand and cement mix to provide a satisfactory working surface for the efficient working of the rubber-tired loader.

\subsection{Overall Mine Design}

The basis for the cost estimates for mining the thoriumbearing veins in the Lemhi Pass area are outlined in this section and are detailed in Appendix A. The constraints of vein geometry, topography and environmental considerations limit both the mine entrance location and potential size of possible mining operations in this district. The site for surface mine buildings exists adjacent to the south fork of the Agency Creek 


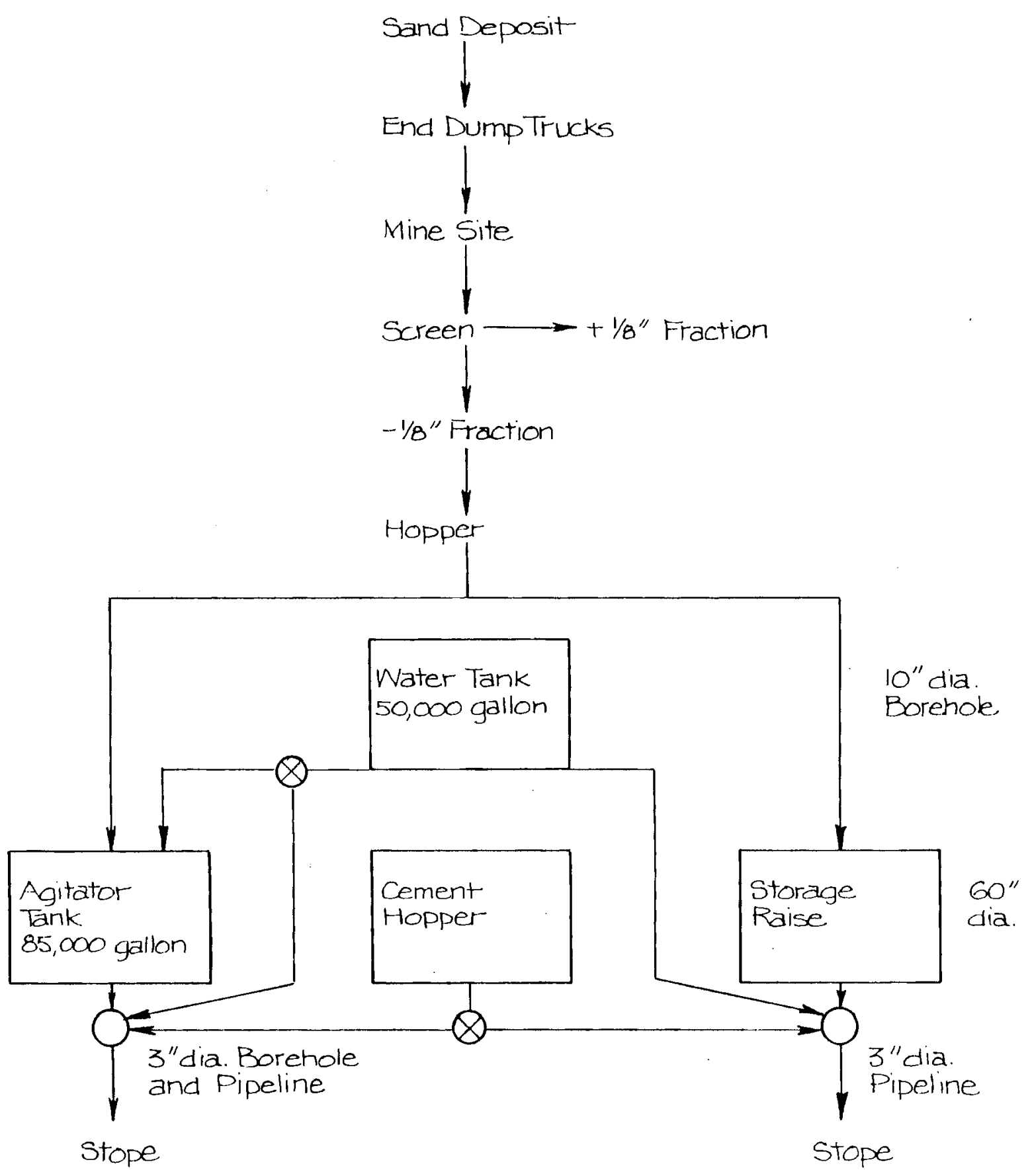


road (ligure 2). The T'endoy Copper Queen Mine and the Wonder Mine were both served by this road.

The portal of the major adit would therefore be sited in this vicinity, which has the added advantage of being only 6,600 feet above mean sea level. This is one of the lowest elevations from which to gain access to the greater part of the lower blocks of the veins selected for mining. The direction of this adit would be approximately due south at a gradient of $+1 / 2$ percent (Figure 2), thus crossing the strike of the known veins at approximately right angles and giving the best chance of exposing additional mineralization. This type of major access is preferred to establish an early cash flow. It offers an apparent cost advantage relative to shaft access, speed of development compared to shaft sinking, cost savings afforded by the use of gravity for ore transportation and drainage, and relative ease and flexibility associated with ventilation. A further four adits are planned to provide access to the upper sections of the lower blocks at 200-foot intervals up to the 7,400-foot level. The upper blocks will also be accessed by a further eight adits.

A production rate of 1,000 tons per day is thought to be a target that can be reasonably attained. Ordinarily, various production capacities would be analyzed and the capacity demonstrating the highest economic return chosen. However, this degree of refinement has not been possible within the scope of this report, and with the restricted geological information available.

Calculations to establish a hypothetical ore reserve were made on six veins selected for their potential mineability. A reserve of approximately 3.5 million tons was estimated from the 
data available, assuming that the veins extended in depth to the level of their respective access adits, and were inclined at the angle of dip measured at their outcrop. Based on these major assumptions, the potential life of the mine is about 14 years at a production rate of 250,000 tons per year (250 days per year; two shifts per day), an estimated mining recovery of 90 percent, and dilution rates of 20 percent in resuing and 10 percent in CuL and I11. 'lhe relative rates of production for the resue and cut and ril1 methods are 20,000 and 230,000 tons per year, respectively during the first four years of production (Figure 6). These change slightly to 10,000 and 240,000 tons per year, respectively, during the fourth year of production and remain at this level until the projected end of operations.

Following the completion of the exploration program and feasibility study, predevelopment of the mine is initiated some eight months prior to the startup of production (Figure 7). This development consists of 4,825 feet of trackless drifts and 1,650 feet of bored and stulled raises for the upper blocks. An additional 1,800 feet of tracked drift is required for the lower blocks. Thus, 12 stopes would be prepared for production to ensure the maintenance of a continuous flow of ore to the mill.

Trackless drifts in conjunction with 10-ton tip-dump trucks were adopted for hauling ore from the upper blocks because of the apparent cost advantage of this system relative to tracked drifts. The advantage of rubber-tired equipment derives from the short hauls involved (average of 1,500 feet), its flexibility, versatility, simplicity, and the lower tonnages available in the upper blocks. Conversely, these distances are too great for a reasonably sized load-haul-dump unit. The tracked haulage favored for the greater haul distances and tonnages of the lower blocks consists of a 10-ton locomotive and 
PRODUCTION AND DE LEMHI PASS THORIUI

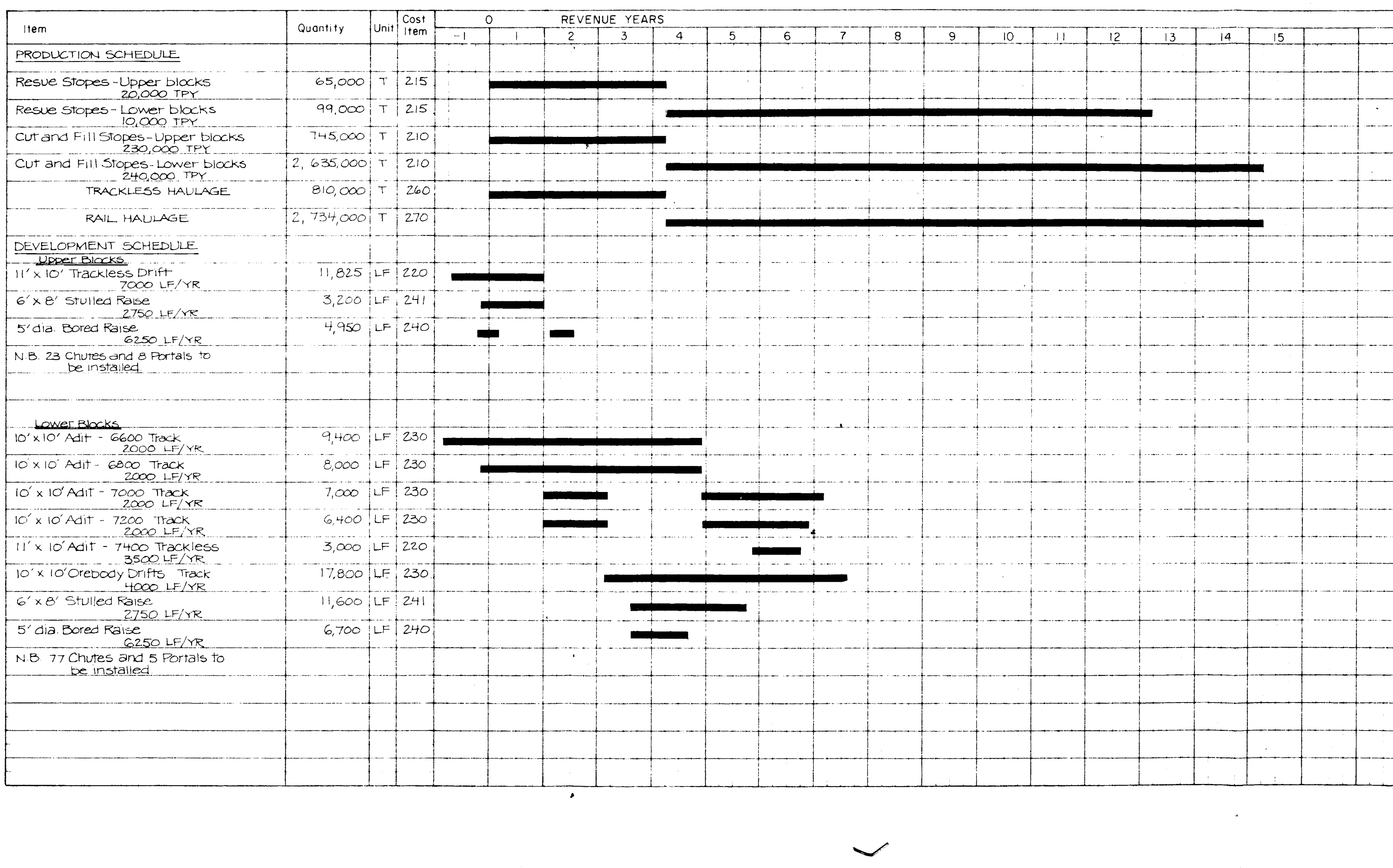


PRODUCTION AND DEVELOPMENT SCHEDULES

LEMHI PASS THORIUM DEPOSITS

Figure 6

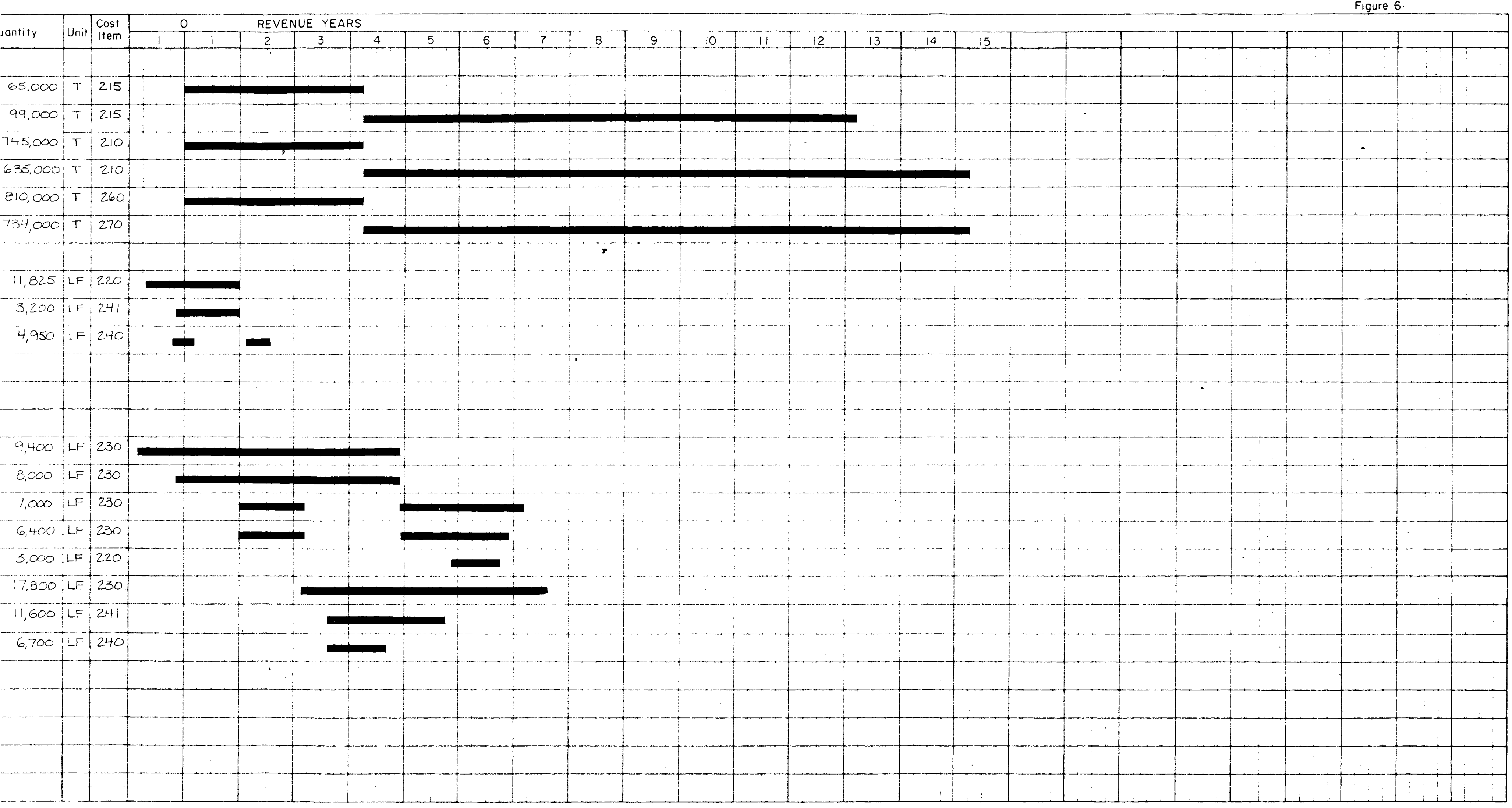




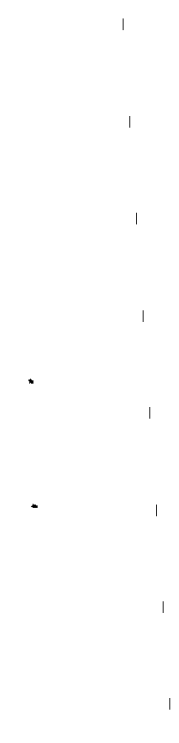




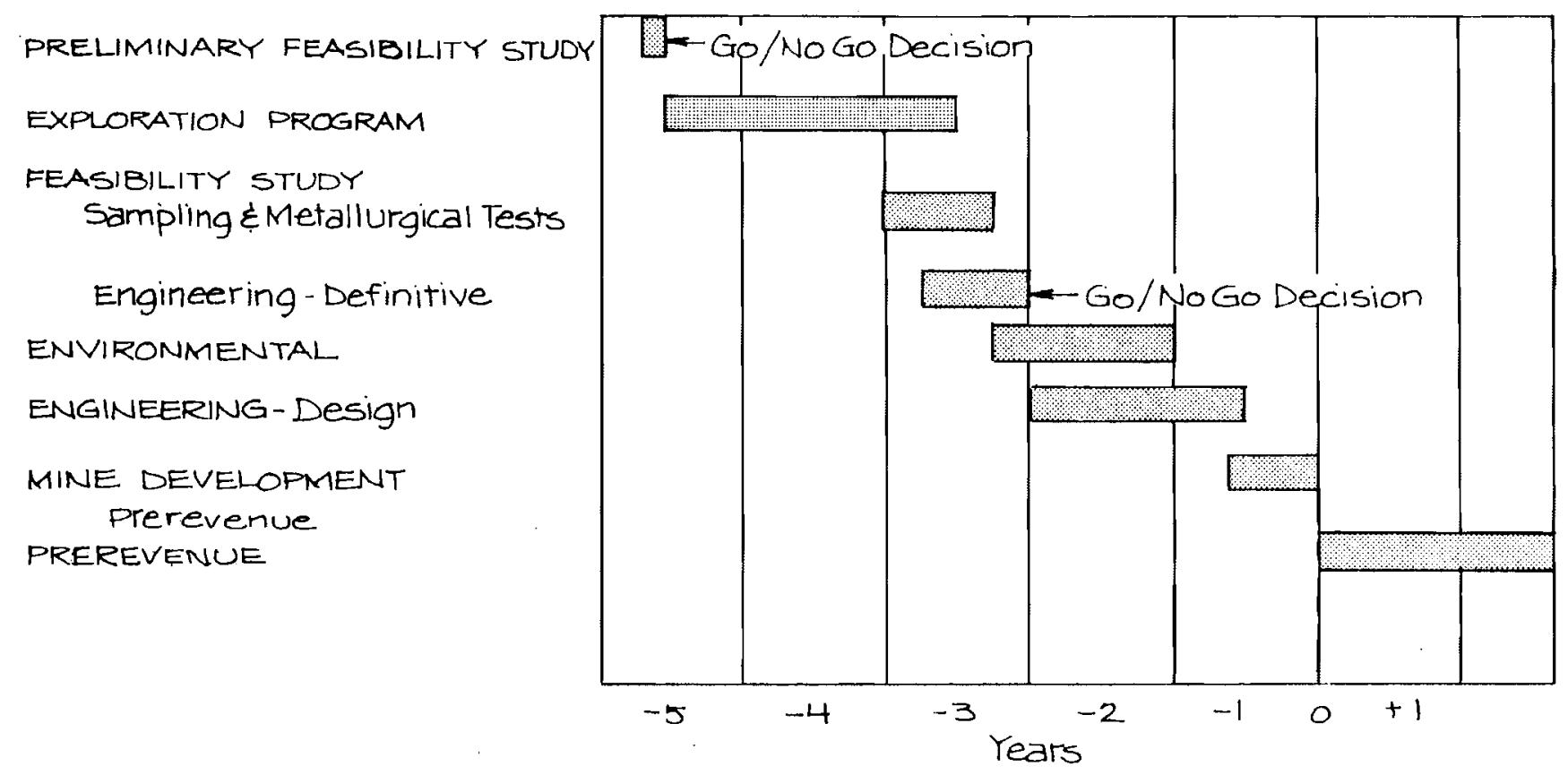


10 cars of 7 ton capacity. Width and height of the tracked and trackless drifts for the necessary haulage equipment and ventilation are $10 \mathrm{ft}$ by $10 \mathrm{ft}$ and $11 \mathrm{ft}$ by $10 \mathrm{ft}$, respectively. Two boom drilling jumbos with 10-foot feeds will be used for the development of the drifts. A 2 cubic-yard load-haul-dump unit with an ejector bucket will clean the trackless drift and an air-powered overshot mucker with conveyor belt will clean the development muck from the tracked drift.

Development costs for the various drifts have been estimated exclusive of support costs (Appendix A6). If ground conditions are such that support is required, as is thought most likely, the cost of support will increase the overall development cost about $\$ 50$ per foot. Some form of shotcrete lining applied by a dry mix shotcrete machine would provide a satisfactory solution to most of the support problems envisaged.

The ventilation of a mine subjected to emission of radon gas requires special attention in its design and application (Rock, 1969, and Schroeder and Evans, 1969). The most important factors accouring to liock (1969) are to:

1. Minimize recirculation.

2. Drive intake air headings (adits, haulages) in barren ground.

3. Maintain fans running during off shifts.

4. Keep mined-out areas on the return side of the ventilation circuit.

5. Drive drifts as large as possible to minimize air resistance.

6. Keep air velocities through the workings at a minimum flow of 100-feet per minute. 
A push-pull system of ventilating the numerous working areas, using secondary fans maintained at a high standard, is considered most suited to dealing with the emission of radon gas from the exposed veins and broken ore. Provision has been made in the project cost to heat the ventilating air during the winter months.

Given the basic configuration of the mine and the production rate of 1,000 tons per day, total manpower requirements have been estimated at 142 , with 112 men required for the operation of the mine, 17 men employed on maintenance duties, and 13 staff to carry out administrative and supervisory roles (Table 2). 
TABL,E 2

MANPOWER REQUIREMENTS AND COSTS AT 250,000 TONS PER YEAR (250 DAYS)

\begin{tabular}{c} 
Number \\
ITEM \\
\hline
\end{tabular}

OPERATING LABOR

Mine

Miners

11.2590 .00

20

40

Fill Crew

$7.13 \quad 57.00$

3

2

6

Miners-Develop

$11.25 \quad 90.00$

14

2

28

Diamond Drillers

11.2590 .00

2

2

4

10-Ton Truck Operators

11.2590 .00

11.2590 .00

3

2

Loco Operators

Timber/Pipe/Vent. Crews

9.7578 .00

2

2

6

Track/Tool/Supply \& Labor Crews

$7.13 \quad 57.00$

$\begin{array}{lll}6 & 2 & 12\end{array}$

$6 \quad 2 \quad 12$

Sub-Tota1

112

Maintenance

Electricians

$\begin{array}{rr}11.25 & 90.00 \\ 11.25 & 90.00 \\ 7.50 & 60.00 \\ 9.75 & 78.00 \\ 7.13 & 57.00\end{array}$

2

2

Mechanics

Lampman.

Drill Doctors

Supply/Labor Crews

$7.13 \quad 57.00$

$\begin{array}{llr}1 & 2 & 2 \\ 2 & 2 & 4 \\ 1 & 1 & 1 \\ 1 & 2 & 2 \\ 4 & 2 & \underline{8} \\ & & \end{array}$

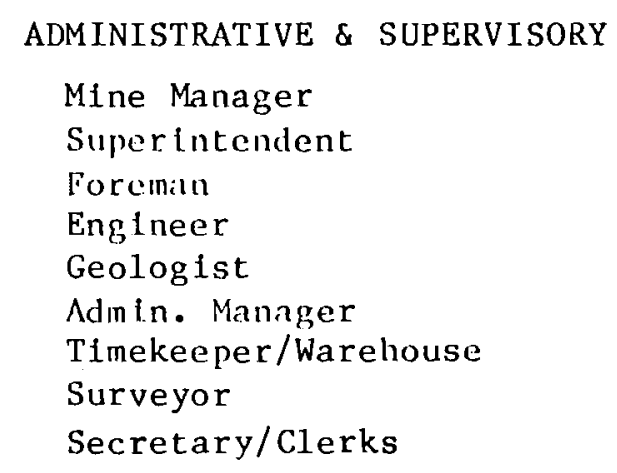

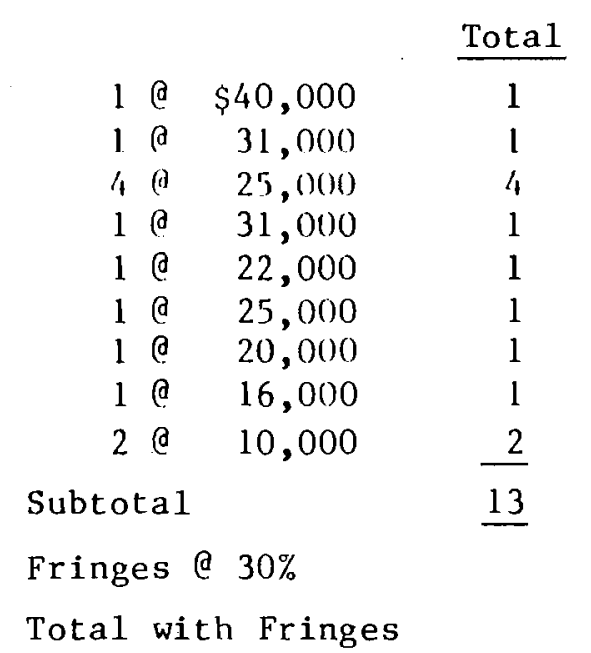

$$
\begin{aligned}
& \frac{\$ / \text { Year }}{\$ 40,000} \\
& 31,000 \\
& 100,0000 \\
& 31,000 \\
& 22,000 \\
& 25,000 \\
& 20,000 \\
& 16,000 \\
& 20,000 \\
& \hline \$ 305,000 \\
& 91,500 \\
& \hline 396,500 / Y R
\end{aligned}
$$

MANPOWER GRAND TOTAL 142 


\subsection{PROJEC'I COS'IS}

The capital and operating costs outlined in this section are founded on the proposed development of a mining complex and infrastructure to mine six thorium-bearing veins with an estimated hypothetical ore reserve of approximately 3.5 million tons. These costs are related to the mining costs, inclusive of water and waste management but exclusive of the cost of milling, environmental considerations, disposal of mill tailings, land acquisition and royalties.

\subsection{Exploration and Prerevenue Expenditure}

The main stages of the exploration and prerevenue program include the preliminary feasibility study, drilling program, feasibility study, engineering design, mine development and mill construction (Figure 7). During the later stages of the exploration program, assuming that initial ore reserve calculations are encouraging, a sampling and metallurgical testing program should be initiated. The data developed from these tests will provide information relative to milling characteristics, recoveries, costs and design parameters.

With regard to environmental considerations, it may be expedient to provide data for purposes of aiding in the preparation of impact statements. Such data may also be useful to concerned agencies as an indication that adequate consideration to the environment has been given. The cost and timing of this expenditure nre dependent an the particular locnl chvirenment, location, proposed extent of operations and political climate. Consequently, the magnitude of the cost and timing of this effort are difficult to estimate and have not been attempted. Careful analysis of the preliminary environmental data should be 
conducted prior to any significant expenditure relative to continuation of the exploration program and feasibility study.

Expenditure for the exploration program amounts to $\$ 1,915,000$, which is just over half the total prerevenue expenditure of $\$ 3,442,000$ (Table 3 ). An allowance of $\$ 100,000$ is made for the feasibility study performed by a firm of consultants and an additional lump sum of $\$ 150,000$ is appraised for the engineering design work. The other major cost item prior to production is the prerevenue development cost at $\$ 1,267,000$ (Table 4). This sum includes $\$ 570,675$ for 6,625 feet of tracked and trackless drifts, $\$ 164,130$ for 1,650 feet of raise development and chute installations and $\$ 450,550$ for indirect charges such as staff salaries, utilities, transport and personnel acquisition and training (Table 4). Minor provisions of $\$ 24,000$ and $\$ 42,420$ have been made for access to and construction of the portals for the upper and lower blocks. The derivations of the units used to calculate the total cost of the different items are detailed in the Appendix.

During this prerevenue period, only nine of the 13 staff necessary for full production are required. Thus, only nine staff members have been accounted for in the eight-month period prior to startup of production. A significant contribution to the cost set against utilities, etc., is made by the operating cost of the transport facilities which are necessary to convey personnel and materials from salmon and Dillon.

\subsection{Operating Costs}

The materials and supply costs for each piece of mining and ancillary equipment were computed based upon the projected productivity of the types of equipment and manpower specified by the mining schedule. 
TARLE 3

ESTIMATED EXPLORATION AND PREREVENUE EXPENDITURES

\begin{tabular}{|c|c|c|c|c|c|c|}
\hline \multirow[b]{2}{*}{ ITEM } & \multicolumn{5}{|c|}{ PROJECT YEAR AND COSTS } & \multirow{2}{*}{$\begin{array}{l}\text { TOTAL } \\
\text { CosT } \$\end{array}$} \\
\hline & -5 & -4 & -3 & -2 & -1 & \\
\hline $\begin{array}{l}\text { Preliminary Feasibility } \\
\text { Study }\end{array}$ & 10,000 & & & & & 10,000 \\
\hline \multicolumn{7}{|l|}{ Exploration Program } \\
\hline Consulting Geologists & 30,000 & 60,000 & 30,000 & & & 120,000 \\
\hline Drilling & 395,000 & 788,000 & 395,000 & & & $1,578,000$ \\
\hline Other & 54,000 & 109,000 & 54,000 & & & 217,000 \\
\hline \multicolumn{7}{|l|}{$\begin{array}{l}\text { Feasibility Study } \\
\text { Englneering }\end{array}$} \\
\hline $\begin{array}{l}\text { economic, marketing, } \\
\text { transport, etc. }\end{array}$ & & & 100,000 & & & 100,000 \\
\hline Englneering-Design & & & & 100,000 & 50,000 & 150,000 \\
\hline $\begin{array}{l}\text { Prerevenue } \\
\text { Development }\end{array}$ & 489,000 & 957,000 & 479,000 & 100,000 & $\frac{1,267,000}{1,317,000}$ & $\frac{1,267,000}{3,442,000}$ \\
\hline
\end{tabular}


TกBL' 4

PREREVENUE DEVELOPMENT

\begin{tabular}{|c|c|c|c|c|c|c|}
\hline \multirow{2}{*}{\multicolumn{2}{|c|}{ ITEM }} & \multirow[b]{2}{*}{ UNITS } & \multicolumn{4}{|c|}{ Costs $(\$)$} \\
\hline & & & LABOR & SUPPLIES & TOTAL & UNIT \\
\hline Trackless Drifts & $11^{\prime} \times 10^{\prime}$ & $4,825^{\prime}$ & 149,575 & 212,300 & 361,875 & $75 / \mathrm{ft}$. \\
\hline Tracked Drifts & $10^{\prime} \times 10^{\prime}$ & $1,800^{\prime}$ & 102,600 & 106,200 & 208,800 & $116 / \mathrm{ft}$ \\
\hline \multicolumn{7}{|c|}{ Stope Development \& Preparation } \\
\hline Bored Raise & $60 "$ dia. & $1,250^{\prime}$ & 30,000 & 50,000 & 80,000 & $64 / \mathrm{ft}$ \\
\hline Stulled Raise & $6^{\prime} \times 8^{\prime}$ & $400^{\prime}$ & 14,800 & 13,600 & 28,400 & $71 / \mathrm{ft}$ \\
\hline Chutes & & 12 & & & 55,730 & 4,644 ea. \\
\hline \multicolumn{7}{|c|}{ Indirects ( 8 months) } \\
\hline Staff Salaries & & & & & 150,000 & \\
\hline Utilities, Trans & sport, Power & & & & 180,550 & \\
\hline Personnel Acquis & sition and 'I & Training & & & 20,000 & \\
\hline \multicolumn{7}{|c|}{$\begin{array}{l}\text { Access Roads (to portals } \\
\text { and levels) }\end{array}$} \\
\hline Site Preparation & Portals & 9 & & & 42,420 & 4,713 ea. \\
\hline \multicolumn{3}{|l|}{ Subtotal } & & \multicolumn{3}{|c|}{$1,151,775$} \\
\hline \multicolumn{2}{|c|}{ Contingency } & & & \multicolumn{2}{|r|}{115,225} & \\
\hline \multicolumn{2}{|c|}{ TOTAL PREREVENUE } & DEVELOPM & $\mathrm{NT}$ & \multicolumn{2}{|r|}{$\$ 1,267,000$} & \\
\hline
\end{tabular}


Supplies are specified as items consumed by or installed on the mechanized equipment, such as fuel, electric power, tires, parts, lubricants, drill stee1 and bits. These costs were assigned either as an operating cost, hourly, per shift, or yearly per operating unit; or, as in the case of drill steel and bits, on a unit footage or tonnage basis. The buildup of machine operating costs generally follow manufacturers' recommendations, except in cases where operating experience or background indicate a more conservative estimate is appropriate. In most cases a more conservative, and hence generally higher, operating cost was derived than that which would be obtained by strictly following manufacturer assessments.

The costs of labor and staff are detailed in Table 2 and reflect the likely rates of pay in the states of Montana and Idaho. The hourly cost given for the operating labor is inclusive of fringe benefits and bonus payments.

Operating costs for the 14-year life of the mine are summarized in Tables 5 and 6 . During the first seven years of production the operating cost per ton of ore is $\$ 22.17$ compared to a cost of $\$ 13.92$ per ton for the final seven years. Over the life of the mine, the average operating cost per ton is $\$ 18.00$. The higher initial operating cost reflects the cost of development and exploration, which are completed during the first seven years of production. Indirect costs also contribute to reduced costs during the final phase of operations since fewer maintenance and supervisory personnel are required. A detailed breakdown of these costs is included in the Appendix. The total operating cost for the producing life of the mine is $\$ 63,781,234$. 
TABLE 5

ESTIMATED OPERATING COSTS TO PRODUCE 1,750,000 TONS,

YEAR 1 to 7 INCLUSIVE

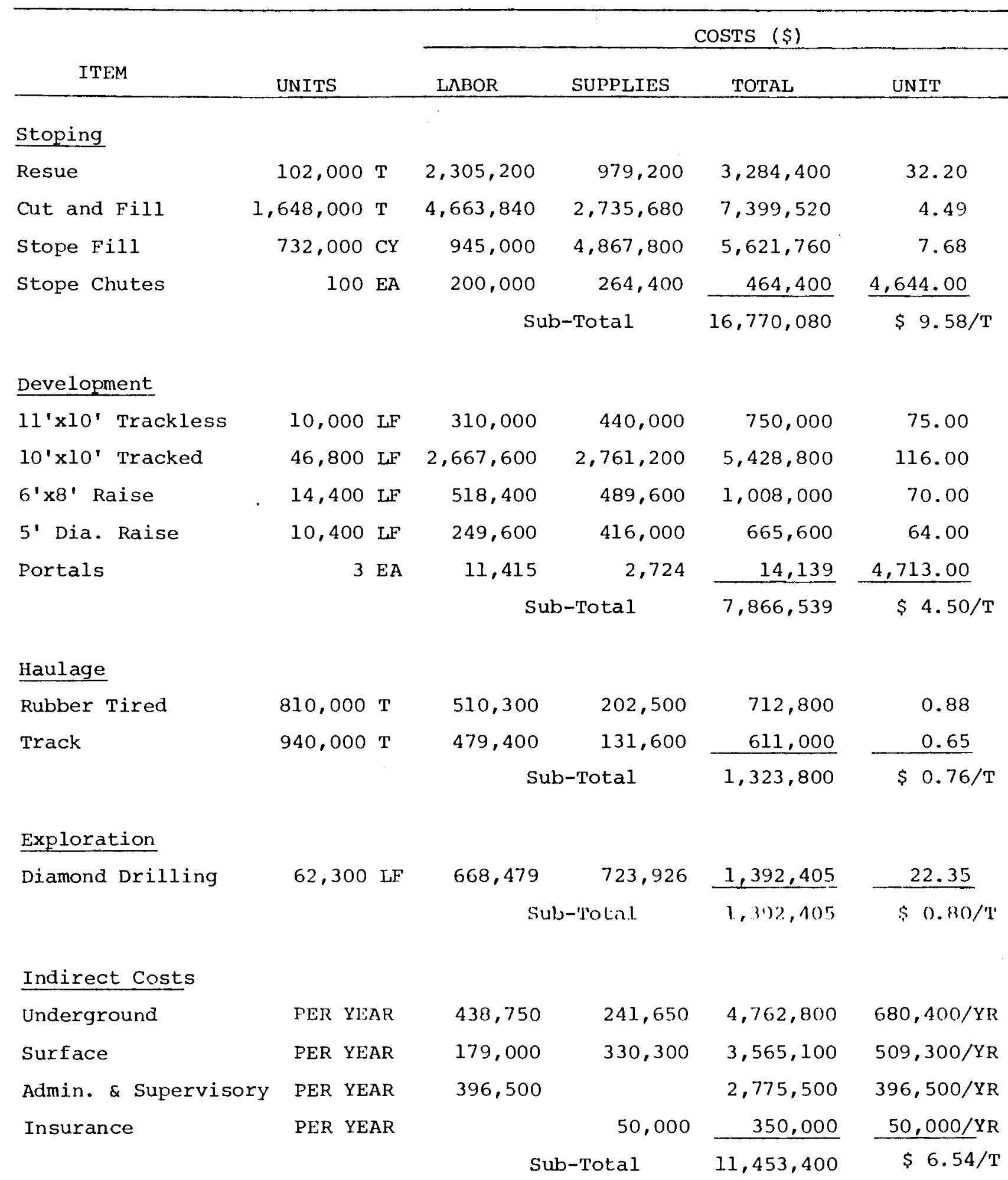

TOTAL OPERATING COSTS FOR YEAR 1 TO 7 INCLUSIVE $=\$ 38,806,224$ 
TABLE 6

ESTIMATED OPERATING COSTS TO PRODUCE $1,794,000$ TONS,

YEAR 8 TO 14.18 INCLUSIVE

\begin{tabular}{|c|c|c|c|c|c|}
\hline \multirow[b]{2}{*}{ ITEM } & \multirow[b]{2}{*}{ UNITS } & \multicolumn{4}{|c|}{$\operatorname{Costs}(\$)$} \\
\hline & & LABOR & SUPPLIES & TOTAL & UNIT \\
\hline \multicolumn{6}{|l|}{ Stoping } \\
\hline Resue & 62,000 & $1,401,200$ & 595,200 & $1,996,400$ & 32.20 \\
\hline Cut and Fill & $1,732,000$ & $4,901,560$ & $2,875,120$ & $7,776,680$ & 4.49 \\
\hline \multirow[t]{2}{*}{ Stope Fill } & 750,400 & 772,912 & $4,990,160$ & $5,763,072$ & 7.68 \\
\hline & & \multicolumn{2}{|c|}{ Sub-Total } & $15,536,152$ & $\$ 8.66 / T$ \\
\hline \multicolumn{6}{|l|}{ Haulage } \\
\hline \multirow[t]{2}{*}{ Track } & $1,794,000$ & 914,940 & 251,160 & $1,166,100$ & 0.65 \\
\hline & & \multicolumn{2}{|c|}{ Sub-Total } & $1,166,100$ & $\$ 0.65 / \mathrm{T}$ \\
\hline \multicolumn{6}{|l|}{ Indirect Costs } \\
\hline Underground & PER YEAR & 303,745 & 222,920 & $3,781,454$ & 526,665 \\
\hline Surface & PER YEAR & 100,500 & 220,030 & $2,301,405$ & 320,530 \\
\hline \multicolumn{6}{|l|}{ Administrative } \\
\hline \multirow[t]{2}{*}{ Insurance } & PER YEAR & & 50,000 & 359,000 & 50,000 \\
\hline & & \multicolumn{2}{|c|}{ Sub-Total } & $8,272,759$ & $\$ 4.61 / \mathrm{T}$ \\
\hline
\end{tabular}

TOTAL OPERATING COSTS FOR YEAR 8 TO 14.18 INCLUSIVE $=\$ 24,975,010$

Cost per ton $\$ 13.92$ 


\subsection{Capita1 costs}

Initial capital expenditure on equipment and buildings amounts to $\$ 3,614,000$ ('Table 7 ). The total cost of replacing equipment during the revenue years of the mine is $\$ 552,500$.

Operating, capital, replacement, depreciation, prerevenue expenditure and amortization costs are summarized in a schedule of estimated annual expenditure shown in Figure 8 .

\subsection{Upper and Lower Bound Costs}

The upper and lower bounds and estimated costs for the project are summarized in lable 8 .

I'ABLE 8

SUMMARY OF UPPER AND LOWER BOUND AND ESTIMATED PROJECT COSTS

\begin{tabular}{lrrr}
\hline \multicolumn{1}{c}{ Cost Center } & \multicolumn{1}{c}{$\begin{array}{l}\text { Lower } \\
\text { Bound }\end{array}$} & $\begin{array}{r}\text { Estimated } \\
\text { Costs } \$\end{array}$ & \multicolumn{1}{c}{$\begin{array}{c}\text { Upper } \\
\text { Bound }\end{array}$} \\
\hline Capital & $3,253,000$ & $3,617,000$ & $5,100,000$ \\
Replacement & 507,000 & 552,500 & 780,000 \\
Prerevenue & $3,240,000$ & $3,442,000$ & $8,000,000$ \\
Total Operating & $\underline{57,400,000}$ & $\underline{63,781,234}$ & $\underline{91,120,000}$ \\
& $\underline{64,400,000}$ & $\underline{71,389,734}$ & $\underline{105,000,000}$ \\
\hline
\end{tabular}

The upper bound estimated cost of $\$ 105,000,000$ is based on the assumptions that ground conditions could be extremely difficult and that the geometry of the veins varies considerably. The cost of the exploration program could therefore conceivably triple. Poor ground conditions would also seriously affect both 
SCHEDULE OF ES

CAPITAL, REPLA

AMORTIZATION C

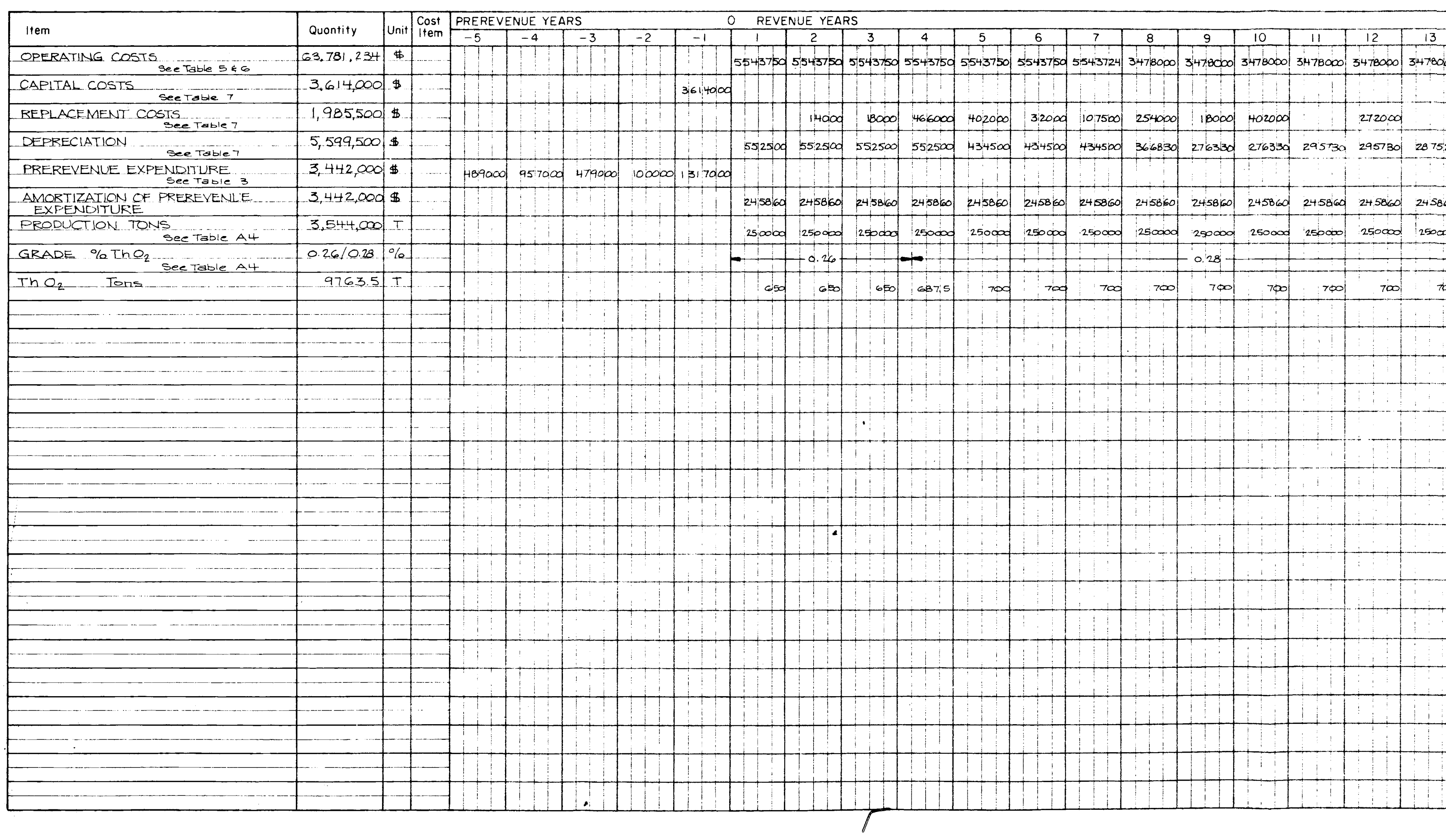



Тา

ESTIMATED CAPITAL EXPENDITURE AND ANNUAL DEPRECIATION

\begin{tabular}{|c|c|c|c|c|c|}
\hline \multirow[b]{2}{*}{ ITEM } & \multirow[b]{2}{*}{ UNITS } & \multicolumn{2}{|c|}{$\operatorname{cosT}(\$)$} & \multirow{2}{*}{$\begin{array}{l}\text { LIFE } \\
\text { YEARS }\end{array}$} & \multirow{2}{*}{$\begin{array}{c}\text { ANNUAL } \\
\text { DEPRECIATION } \\
\end{array}$} \\
\hline & & UNIT & TOTAL & & \\
\hline LHD - 2 Cubic Yard & 1 & 78,000 & 78,000 & 7 & 11,143 \\
\hline Truck 10T & 3 & 124,000 & 372,000 & 7 & 53,142 \\
\hline Jumbo 2 Boom & 1 & 60,000 & 60,000 & 8 & 7,500 \\
\hline Jumbo 2 Boom (Rail) & 4 & 60,000 & 240,000 & 8 & 30,000 \\
\hline Jackleg & 6 & 3,000 & 18,000 & 5 & 3,600 \\
\hline Stoper & 12 & 2,500 & 30,000 & 5 & 6,000 \\
\hline Raise Borer & 1 & 472,000 & 472,000 & 4 & 118,000 \\
\hline Loader $1-3 / 4 \mathrm{~T}$ & 10 & 34,000 & 340,000 & 5 & 68,000 \\
\hline Slusher $15 \mathrm{HP}$ & 5 & 6,000 & 30,000 & 14 & 2,143 \\
\hline Mucker & 4 & 53,000 & 212,000 & 4 & 53,000 \\
\hline Trolley Loco 10T & 1 & 82,500 & 82,500 & 14 & 5,893 \\
\hline Trolley Loco 8T & 1 & 66,000 & 66,000 & 14 & 4,714 \\
\hline Granby Car & 20 & 7,400 & 148,000 & 14 & 10,571 \\
\hline Shotcrete $\mathrm{M} / \mathrm{C}$ & 2 & 7,000 & 14,000 & 5 & 2,800 \\
\hline Diamond Drill & 1 & 8,500 & 8,500 & 7 & 1,214 \\
\hline Tugger Hoist & 15 & 1,500 & 22,500 & 7 & 3,214 \\
\hline Ventilation Ducting & 16,000 & 0.50 & 8,000 & 2 & 4,000 \\
\hline Boss Buggy & 1 & 27,000 & 27,000 & 7 & 3,857 \\
\hline Fan $20 \mathrm{HP} / 10,000 \mathrm{CFM}$ & 18 & 2,500 & 45,000 & 7 & 6,429 \\
\hline Fan $10 \mathrm{HP} / 5,000 \mathrm{CFM}$ & 7 & 2,000 & 14,000 & 7 & 2,000 \\
\hline Compressor $10,000 \mathrm{CFM}$ & 1 & 300,000 & 300,000 & 14 & 21,429 \\
\hline Bus 45 seat & 3 & 80,000 & 240,000 & 4 & 60,000 \\
\hline 5T Truck & 1 & 14,000 & 14,000 & 7 & 2,000 \\
\hline Pickup & 3 & 6,000 & 18,000 & 3 & 6,000 \\
\hline Car & 1 & 6,000 & 6,000 & 2 & 3,000 \\
\hline Offices & & & 40,000 & 14 & 2,857 \\
\hline Workshops and Equipment & & & 145,000 & 14 & 10,357 \\
\hline Compressor House & & & 40,000 & 14 & 2,857 \\
\hline Utilities & & & 125,000 & 14 & 8,928 \\
\hline Powder Magazine & & & 30,000 & 14 & 2,143 \\
\hline \multirow[t]{2}{*}{ Mine Dry } & & & 40,000 & 14 & 2,857 \\
\hline & & & $3,285,500$ & & 519,648 \\
\hline \multirow[t]{2}{*}{ Contingency } & & & 328,500 & 14 & 32,850 \\
\hline & & TOTAL & $3,614,000$ & & 552,498 \\
\hline
\end{tabular}


development and stoping costs. Variable vein grometry would result in increased exploration and development requirements and hence an overall increase in costs.

\subsection{Sensitivity Analysis}

A sensitivity analysis of three parameters has been carried out in order that the estimates made in this study may be applied to similar vein deposits. These parameters are grade, vein width, and ore reserve; the basis on which these analyses were made are:

I) The effect of a change in vein width is related to the cost per pound of $\mathrm{ThO}_{2}$ per stope and not to the overall cost of the mine.

II) The effects of changes in mine grade and ore reserve are related to the cost per pound of $\mathrm{ThO}_{2}$ inclusive of the overall cost of the mine.

III) The costs of development for standard resue and a cut and fill stopes per $300^{\prime}$ strike length and $231^{\prime}$ dip length are 56,712 dollars and 43,314 dollars, respectively. These costs include 4,644 dollars for the installation of chutes.

\subsubsection{Grade Variation}

The total cost of $\mathrm{ThO}_{2}$ produced from the proposed mine is 3.66 dollars per pound at a grade of 0.28 percent Tho 2 . Grade is directly related to the cost per pound of $\mathrm{ThO}_{2}$ ('Table 9). 
TABLE 9

EFFECT OF $\Lambda$ VARIATION IN MINE GRADE

ON THE COST OF $\mathrm{ThO}_{2}$

\begin{tabular}{lcccc}
\hline \multirow{2}{*}{$\begin{array}{c}\text { Grade } \\
\text { Percent }\end{array}$} & $\begin{array}{l}\text { Lb. Th0 } \\
\text { Per Ton }\end{array}$ & \multicolumn{3}{c}{ CosTS/LB. $(\$)$} \\
\hline 0.1 & 2 & 9.00 & 1.08 & 10.08 \\
0.2 & 6 & 3.00 & 0.36 & 3.36 \\
0.5 & 10 & 1.80 & 0.22 & 1.44 \\
0.7 & 14 & 1.29 & 0.15 & 1.12 \\
0.9 & 18 & 1.00 & 0.12 & 1.01 \\
1.0 & 20 & 0.90 & 0.11 & 0.50 \\
2.0 & 40 & 0.45 & 0.05 &
\end{tabular}

Thus, if the average grade of ore varied from 1 percent to 0.1 percent, the cost per pount of $\mathrm{ThO}_{2}$ produced would vary between 1.01 dollars and 10.08 dollars, respectively.

\subsubsection{Vein Width Variation}

A change in the width of veins has a significant effect on the cost per pound of $\mathrm{ThO}_{2}$ produced by the resue stoping method (Table 10). The grade assumed for the purpose of analyzing the sensitivity of the cost of $\mathrm{ThO}_{2}$ to vein width is 0.28 poreont of 5.6 lb. por lom ol ore. 
TABLI 10

EFFECT OF A VARIATION IN VEIN WID'TII

ON TIIE COST' OF $\mathrm{ThO}_{2}$

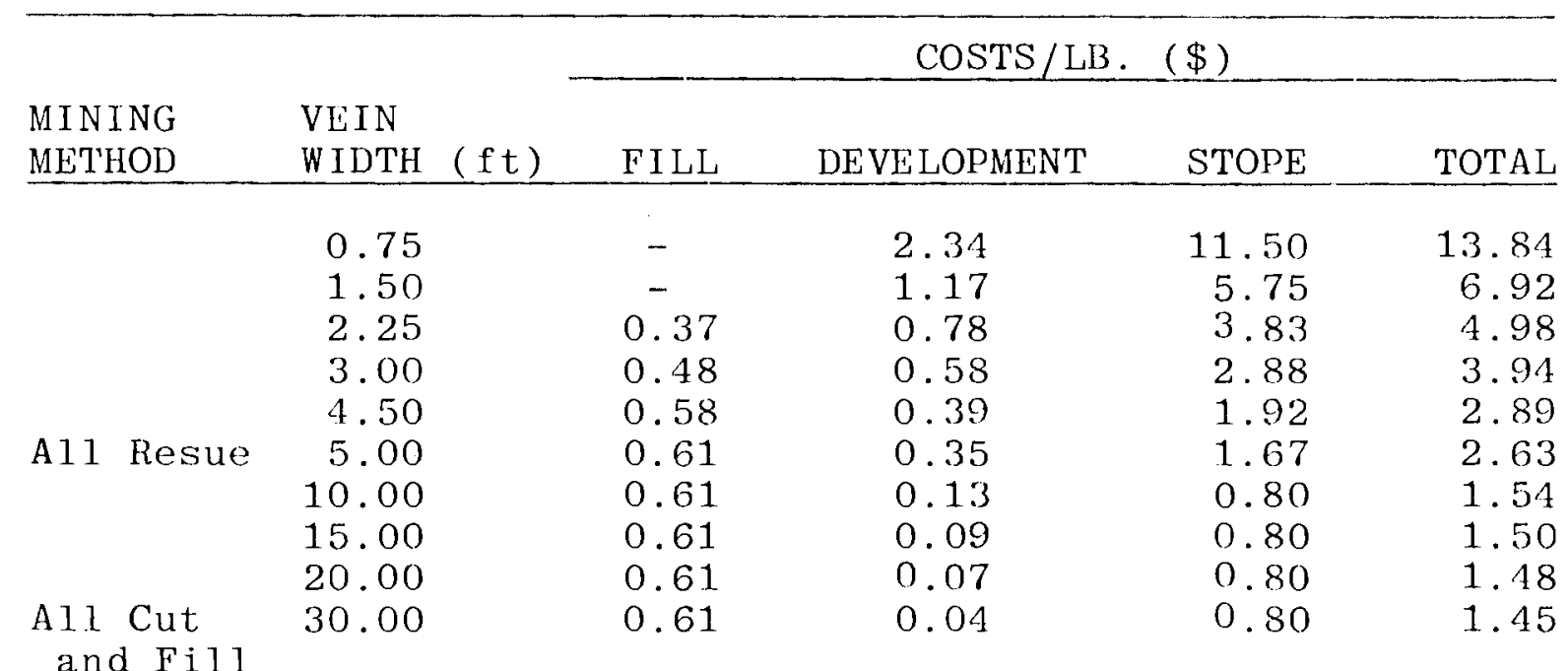

From Table 10 it can be seen that it is necessary to introduce fill into the resue stopes with vein widths of $2.25 \mathrm{ft}$, and both development and stoping costs greatly affect the cost of $\mathrm{ThO}_{2}$ in resue stopes with vein widths up to $5 \mathrm{ft}$. Thereafter, in cut and fill stopes, only the cost of development changes by a small amount. Only stope development is included for this analysis. Thus, for a variation in vein width from $0.75 \mathrm{ft}$. to $30 \mathrm{ft}$, the cost of $\mathrm{ThO}_{2}$ changes from 13.84 dollars to 1.45 dollars per pound, respectively.

\section{5 .3 Ore Reserve Variation}

The effect of a variation in ore reserve on the cost of a pound of $\mathrm{ThO}_{2}$ is controlled by a number of factors. For example, the distance between the vein deposits of Tho 2 can require extensive development to expose even decreasing amounts of ore of diminishing grade. The datum for this sensitivity analysis is the ore reserve of 14,161 tons as indicated in 
Table A4.1, of which only 9761 tons can be mined. The maximum additional ore reserve available for this analysis is some 23,751 tons of $\mathrm{ThO}_{2}$, as detailed in Table A4.2, of which on $1 \mathrm{y}$ 13,993 tons can be extracted. The effect on the cost of $\mathrm{ThO}_{2}$ of mining this extra ore is enumerated in three stages (Table 11). Other veins in the district that contain thorium have been studied for this analysis, such as the Lucky Horseshoe and the Buffalo veins, but have no- been used, as a shaft is required for their development. It has not been possible to account for the cost of a shaft within the time constraints of this report. The effect on the cost of $\mathrm{ThO}_{2}$ by sinking shaft is difficult to assess without a detailed study, for while capital expenditure is necessary for its development, operating costs would be increased by hoisting operations. The ore reserve could be improved not only from the Lucky Horseshoe veins but also from such veins as the Wonder Lode and Last Chance veins.

TABLE 11

EFFECT OF A VARIATION IN MINING

RESERVE ON THE COST OF $\mathrm{ThO}_{2}$

\begin{tabular}{|c|c|c|c|c|c|}
\hline \multirow[b]{2}{*}{$\begin{array}{l}\text { Mining Reserve } \\
\text { Tons of } \mathrm{ThO}_{2} \\
\end{array}$} & \multirow[b]{2}{*}{$\begin{array}{l}\text { Mean } \\
\text { Grade \% }\end{array}$} & \multicolumn{3}{|c|}{ COsT } & \multirow[b]{2}{*}{$\$ / L B$} \\
\hline & & Capital & Operating & Total & \\
\hline 9,761 & 0.28 & $7,611,500$ & $63,781,234$ & $71,392,734$ & 3.66 \\
\hline 11,762 & 0.40 & $3,000,000$ & $84,084,000$ & $87,084,000$ & 3.70 \\
\hline 413 & 0.51 & 20,000 & $4,200,000$ & $1,220,000$ & 5.19 \\
\hline 1,818 & 0.46 & $1,000,000$ & $18,350,000$ & $19,350,000$ & 5.32 \\
\hline
\end{tabular}

It is evident from Table 11 that the estimated cost per pound of thorium increases from 3.66 dollars to 5.32 dollars as mining reserves increase from 9761 tons to 23,754 tons, respectively. The major factors which contribute to this 
increase are the distance of the veins from the mine site in Agency Creek and that the final 2200 tons of $\mathrm{ThO}_{2}$ are extracted by resuing methods. Further, the high capital cost to remove the final 2200 tons is necessitated by the purchase of additional haulage trucks and road construction. A haulage cost of 2.00 dollars per ton was estimated to move the ore from the Bear and Trapper Creeks to Agency Creek. Other cost factors for this analysis were take from Tables 5, 6, and 7 .

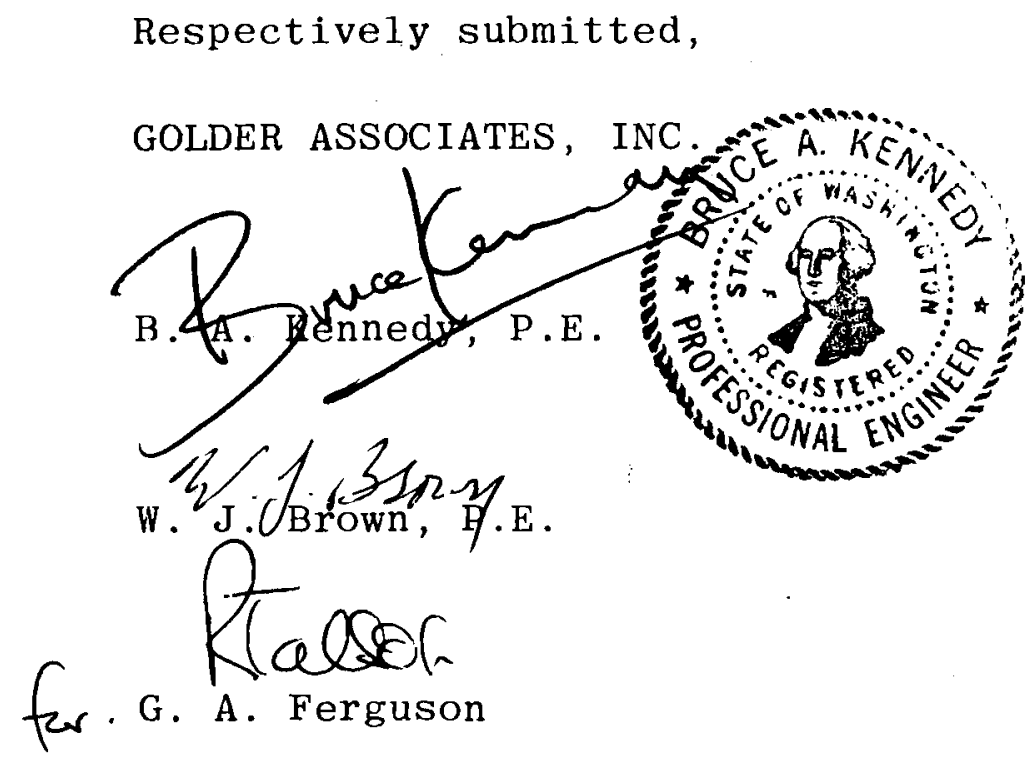


RELERLENCES

ANDELSON A.L., 1958. Uranium, thorium, columbium and rare earth deposits in the Salmon region, Lemhi County, Idaho. Idaho Bureau of Mines and Geology, Pamphlet 115. 81 pp.

AUSTIN S.R., HETLAND D.L., SHARP B.J., 1970. Mineralogy of the Lemhi Pass, thorium and rare earth deposits. Idaho Bureau of Mines and Geology, Mineral Resources Report 11. $10 \mathrm{pp}$.

ENG F.G., 1960. Geology of the Lucky Horseshoe thorium deposit, Lemhi County, Idaho. M.Sc. Thesis, University of Idaho, Moscow (83843).

GEACH R.D., MATSON R.E., 1966. Thorium deposits of the Lemhi Pass district, Beaverhead County, Montana. Montana Bureau of Mines and Geology, SP 41.

HAP'TONSTALL J.C., 1978. Modernization of the Tayoltita Mine, one of Mexico's major silver and gold operations. Mining Engineering, pp. 171-176.

NEWTON J., et al., 1960. Study of two Idaho thorite deposits . Idaho Bureau of Mines and Geology, Pamphlet 122. 57 pp.

ROCK R.L., 1969. Mine engineering and ventilation problems unique to the control of radon daughters. U.S.B.M. Report No. 1001 .

SCHIPPER W.B., 1955. The Tendoy Copper Queen Mine. M.Sc. Thesis, University of Idaho, Idaho. 
SCllROEDliR G.L., LVANS R.I)., 1969. Some basic concopts in uranium mine ventilation. Society of Mining lingineers, AIME, Transactions, Vol 244, pp. 301-307.

SHARP W.N., CAVENDER W.S., 1962. Geology and thorium- bearing deposits of the Lemhi Pass area, Lemhi County, Idaho and Beaverhead County, Montana. U.S.G.S. Bulletin 1126, pp. 76 with maps, etc.

STAATZ M.H., 1972. Geology and description of the thorium-bearing veins, Iemhi Pass Quadrangle, Idaho and Montana. U.S.G.S. Bulletin 1351, 94 pp., with map.

STAATZ M.H., 1973. Geologic map of the Goat Mountain Quadrangle, Lemhi County, Idaho, and Beaverhead County, Montana. U.S.G.S. Geological Quad. Map GQ-1097.

STAATZ M.H., 1974. Thorium veins in the U.S. Econ. Geol. V. 69 , p. 494-567.

TRITES A.F., TOOKER E.W., 1953. Uranium and thorium deposits in east-central Idaho and southern Montana. U.S.G.S. Bulletin 988-H. 
APPENDIX A

UNDERGROUND MINING OF THORIUM DEPOSITS, LEMHI PASS

The basic data utilized to determine the costs given in this report are detailed in this appendix.

\section{A.1 DIAMOND DRILLING}

$\underline{\text { Data }}$

1. Geological vertical sections required on 100 -foot centers.

2. Three holes drilled per section, at $-60^{\circ}$ to intersect vein at vertical depths of 250 feet, 500 feet and 750 feet below surface.

3. Length of drilling per section $=250^{\prime}+500^{\prime}+750^{\prime}=1730^{\prime}$

$$
\sin 60^{\circ}
$$

4. Forty sections drilled for feasibility study, or about 70,000 feet. A further 36 sections drilled from startup of production to year 7, approximately 62,300 feet.

5. Advance rate of 20 feet per shift, i.e., 25 shifts for 500 foot hole plus three shifts moving machine.

Costs - Item 280

1. Average drilling cost per foot in $1976-\$ 14.50$ exclusive of ancillary charges.

2. Inflation discounted at six percent per year and ancillary charges at 38 percent.

3. $1978 \mathrm{drilling}$ cost $=\$ 14.50 \times 1.38 \times 1.12=\$ 22.35$, made up of $\$ 10.73$ labor and $\$ 11.62$ supplies.

4. Estimated 1 ife of dril1 bit, 500 fect, at a cost of $\$ 10$ per foot.

A.2 RESUE STOPING

Data

1. Slushing limit of 150 feet to give stope length of 300 feet.

2. Single central raise of stopes, raise bored to provide adequate ventilation.

D.A. 1 
3. Stope thickness 5 feet: waste 3.5 feet, ore 1.5 feet.

4. Drilling efficiency 35 feet/man-hour.

5. Drilling required for $24 \mathrm{~T}$ of waste and $10^{\prime} \mathrm{T}$ ore per shift, is 140 feet and 90 feet respectively. Length of round along strike 15 feet drilled with 6-ft steels. 6. Total drilling time for driller $\frac{140^{\prime}+90^{\prime}}{35^{\prime} / \mathrm{MH}}=6.6$ man-hours.

7. Average cycle time for $10 \mathrm{H.P}$. slusher over $75-\mathrm{ft}$. pull with 30 -inch slusher is 1.10 minutes per 627 pound load in iron ore.

Equivalent in quart/z $3.8 \mathrm{~min} / \mathrm{T}$,

i.e., $2.2 \mathrm{Hr}$. for slushing per shift.

8. Shift work of second crew member:

$2.2 \mathrm{Hr}$. - Slushing

$1.0 \mathrm{Hr}$. - Trimming

$3.2 \mathrm{Hr}$. - Loading holes

$0.2 \mathrm{Hr}$. Utilities

$6.6 \mathrm{Hr}$.

9. Each 12-foot lift, four crew shifts are estimated to move cribbing and slusher.

10. Ore tons per stope lift $=\frac{300^{\prime} \times 1.5^{\prime} \times 12^{\prime}}{12 \mathrm{ft}^{\prime} / \mathrm{T}}=450 \mathrm{~T}$

11. Productivity of two-man crew $=\frac{450 \mathrm{~T}}{10 \mathrm{~T}}=45 \mathrm{crew}$ shifts +4 crew shifts moving to other stopes, therefore $\frac{450 \mathrm{~T}}{49 \text { crew shifts }}$ $=9 \mathrm{~T} / \mathrm{shift}$ or $4.5 \mathrm{~T} / \mathrm{man}-\mathrm{shift}$.

12. Slusher repair costs estimated at $\$ 5.00$ per hour for parts and supplies. Steel rope costs figured at $\$ 1.00$ per foot, or $\$ 300$ per stope. Life estimated at 40 shifts, thus cost per shift is $\$ 7.50$.

13. Explosives use estimated at $2.51 \mathrm{~b}$. per ton of ore for 75 percent ANFO - 25 percent Dynamite. 


\section{Costs - Item 210}

1. The contribution of labor and supplies to the cost of $\$ 32.20 /$ ton of ore by resue stoping is given in Table A1.

2. Average explosives cost, including caps, is $\$ 0.63$ per ton of ore broken.

\section{A.3 CUT AND FILL STOPING}

Data

1. Standard stope thickness - 10 feet.

2. One 10-ft. breast round drilled per shift by two men, third crew member mucks and charges drill holes. Area of rock per round is 78 square feet. Thus, number of holes per round $=\frac{78 \mathrm{sq} \cdot \mathrm{ft} .}{3 \mathrm{sq} \cdot \mathrm{ft} \cdot / \text { hole }}=26.33$ rounds needed per lift.

3. Tonnage broken per round - 58 tons.

4. Central ore pass required per 300-foot long stope.

5. Productivity of three-man crew - 116 tons per shift.

6. Stope volume $=\frac{300^{\prime} \times 10^{\prime} \times 200^{\prime}}{\sin 60^{\circ}}=\frac{693,000 \mathrm{ft}^{3}}{}$

therefore, tons per stope $=\frac{693,000 \mathrm{ft}^{\prime} 3}{12 \mathrm{ft}, 3 / \mathrm{T}}=57,700$ tons

7. Stopes required to produce 900 tons per day $=$

$$
\frac{900}{116}=8 \text { stopes }
$$

8. Powder factor - $21 \mathrm{~b}$. per ton of ore or $1161 \mathrm{~b}$. per round.

9. 75 board feet of cribbing placed per foot of raise.

10. Estimated productivity of air loader - 40 tons per hour. Muckout time $\frac{58 \mathrm{~T}}{40 \mathrm{TPH}}=1.5 \mathrm{Hr}$ for $150^{\prime}$ tramming distance.

Costs - Item 210

1. The breakdown of labor and supplies towards the $\$ 4.49$ cost per ton ore is detailed in Table A2.

2. Miscellaneous stope timber is not included in direct stope costs. 
TABLH: A1.

ESTIMATED COST OF RESUE STOPING

\begin{tabular}{|c|c|c|c|c|c|}
\hline Cost Item & Units & Labor & Supplies & Total & $\begin{array}{l}\text { Unit } \\
\text { Cost }\end{array}$ \\
\hline Miners $4.5 \mathrm{~T} / \mathrm{MS}$ & $2.22 \mathrm{MS}$ & 200 & & 200 & 90 \\
\hline Bits \& Steel & $2.30 \mathrm{LB}$ & & 23 & 23 & $0^{10}$ \\
\hline Explosives & $85 \mathrm{LB}$ & & 21 & 21 & $0^{25}$ \\
\hline Raise Cribbing & $0.28 \mathrm{LF}$ & & 21 & 21 & $37^{34}$ \\
\hline Stopers (4) & $6.60 \mathrm{Hr}$ & 20 & 23 & 43 & $6^{50}$ \\
\hline 15 HP Elec. Slusher & $2.20 \mathrm{Hr}$ & 6 & 8 & 14 & $6^{00}$ \\
\hline Cost/Round & & 226 & 96 & 322 & \\
\hline Cost/Ton & & $22^{60}$ & $9^{60}$ & $32^{20}$ & \\
\hline
\end{tabular}

NOTE: Basis of estimate is one round in ore plus removal of $3 \frac{1}{3}$ ft. thickness of waste. This would yield 10 tons of ore. Figure 1 round is $15 \mathrm{I}$. F. along strike, drill 6 ft, pull $5 \frac{1}{2} \mathrm{ft}$. This would be one shift work for 2 men, $10^{\prime} \Gamma /$ crew-shift. 
T $\Lambda$ BJ.]: A2

\section{ESTIMATED COST OF CUT AND FILL STOPING}

\begin{tabular}{|c|c|c|c|c|c|}
\hline Cost Item & Units & Labor & Supplies & Tota 1 & $\begin{array}{l}\text { Unit } \\
\text { Cost }\end{array}$ \\
\hline Miners $38.7 \mathrm{~T} / \mathrm{MS}$ & $1.50 \mathrm{MS}$ & 135 & 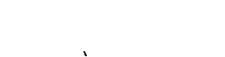 & 135 & 90 \\
\hline Bits \& Steel & $260 \mathrm{LF}$ & & 26 & 26 & $0^{10}$ \\
\hline Explosives & $116 \quad \mathrm{I} J 3$ & & 29 & 29 & $0^{2.5}$ \\
\hline Raise Cribbing & $0.28 \mathrm{LF}$ & & 10 & 10 & $37^{34}$ \\
\hline Jacklegs (4) & $6.50 \mathrm{HR}$ & 20 & 23 & 43 & $6^{50}$ \\
\hline $1^{3} / 4 \mathrm{~T}$ R.T. Loader & $1.50 \mathrm{HR}$ & 9 & 8 & 17 & $11^{00}$ \\
\hline Cost/Round & & 164 & 96 & 260 & \\
\hline Cost/Ton & & $2^{83}$ & $1^{66}$ & $4^{49}$ & \\
\hline
\end{tabular}

NOTE: Basis of estimate is one breast round of advance. One round breaks 58 Tons. In one work place 2 men drill, 1 man mucks, loads holes, raises cribbing. Total productivity is $58 \mathrm{~T} \times 2$ rounds $\div 3 \mathrm{MS}=38.7 \mathrm{~T} / \mathrm{MS}$; $116 \mathrm{~T} / \mathrm{Crew}-\mathrm{shift}$ 
3. Cribbing labor included under stope labor.

4. Cost of cribbing - $\$ 500$ per 1,000 board feet.

5. Jackleg labor cost $-\frac{260 \mathrm{ft} .}{40 \mathrm{ft} / \mathrm{Hr} .}=6.5 \mathrm{Hr}$.

6. Average explosives cost, including caps, $\$ 0.50$ per ton.

\section{A.4 BACKF ILL SYSTEM}

Data

1. Flow rate of slurry, 200 gallons per minute or 50 tons of dry solids per hour to fill one lift of 10-foot wide stope in three shifts of 6.5 hours' duration.

2. Stope fill crew to consist of three men.

3. Top 6-inch sand-cement mat of each fill lift requires 435 sacks of cement at $\$ 3.00$ per sack.

4. Cost of sand assumed at $\$ 5.00$ per cubic yard could be more or less dependent upon actual source.

5. Normal fill cycle will place 1,350 dry tons of sand.

\section{Costs - Item 205}

1. The makeup of the cost of labor and supplies to 1 cubic yard of fill at $\$ 7.94$ per cubic yard is detailed in Table A3.

\section{A.5 ORE RESERVES}

Hypothetical ore reserves have been developed from the data available and the assumptions that the six veins chosen extend in depth to the level of thoir respoctive accessis ad is. Idealized sections were drawn up; Figure A1 to A4, from which hypothetical volumes of veins were determined. From these, ore and mining reserves were assessed. These reserves are summarized in Table A4. A bulk density of $1651 \mathrm{~b} / \mathrm{ft} 3$ was assumed for the conversion of volumetric ore reserves. 
TABLE A3

ESTIMATED COSTS OF SANDFILL

\begin{tabular}{|c|c|c|c|c|c|}
\hline Cost Item & Units & Labor & Supplies & Tota 1 & $\begin{array}{l}\text { Unit } \\
\text { Cost }\end{array}$ \\
\hline \multicolumn{6}{|c|}{ Filling Operations: } \\
\hline U.G. Labor & $9 \mathrm{MS}$ & 513 & & 513 & 57 \\
\hline Pipe & $1 \mathrm{I} . \mathrm{S}$ & & 150 & 150 & \\
\hline Sealing Stope & $9 \mathrm{MS}$ & 513 & 200 & 813 & 57 \\
\hline Cement & $435 \mathrm{SK}$ & & 1300 & 1300 & $3^{00}$ \\
\hline Sand & $1000 \mathrm{Cy}$ & & 5000 & 5000 & $5^{00}$ \\
\hline Cost/1000 Cy & & 1026 & 6650 & 7676 & \\
\hline $\operatorname{Cost} / \mathrm{Cy}$ & & $1^{29}$ & $6^{65}$ & $7^{68}$ & \\
\hline
\end{tabular}

NOTE: Usual filling cycle would be: $300^{\prime} \times 8^{\prime} \times 11.6 \div 27=$ $1000 \mathrm{Cy}=1350$ Dry Tons Sand. 

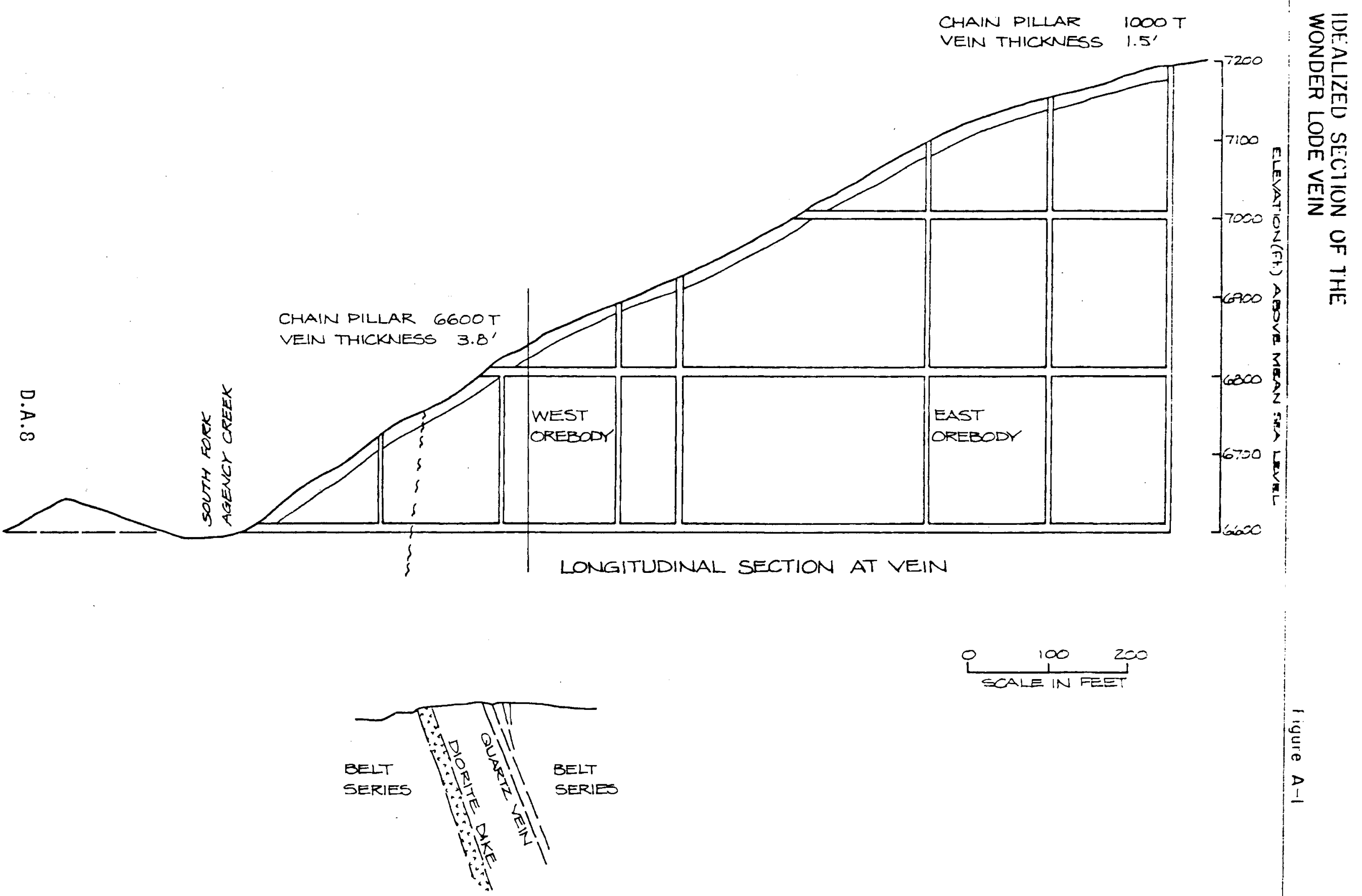
CHAIN PILLAR

$\begin{array}{ll}\text { SILL PILLAR } & =8,000 \mathrm{~T} \\ \text { TOTAL LOSS IN PILLARS } & =23,000 \mathrm{~T}\end{array}$

$=15,000 \mathrm{~T}$

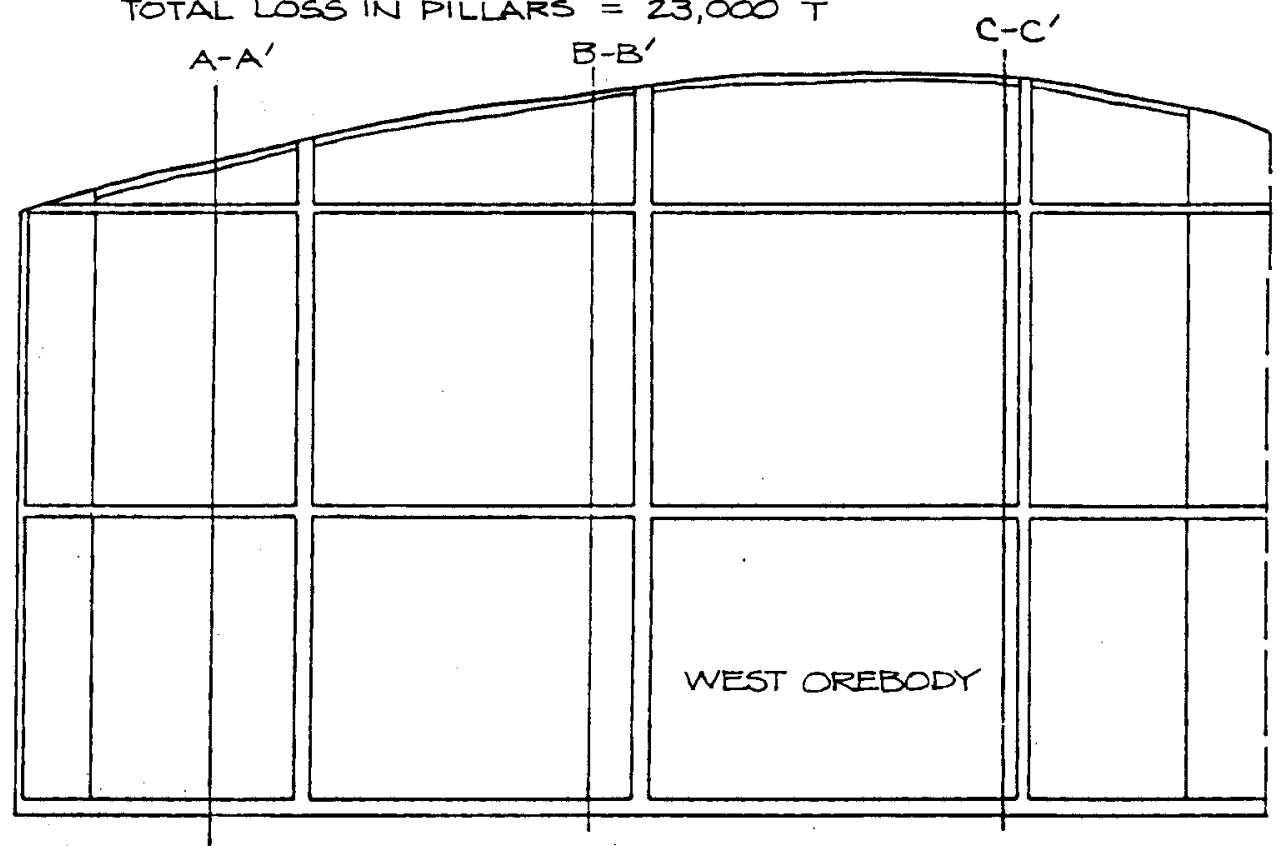

LONGITUDINAL SECTION

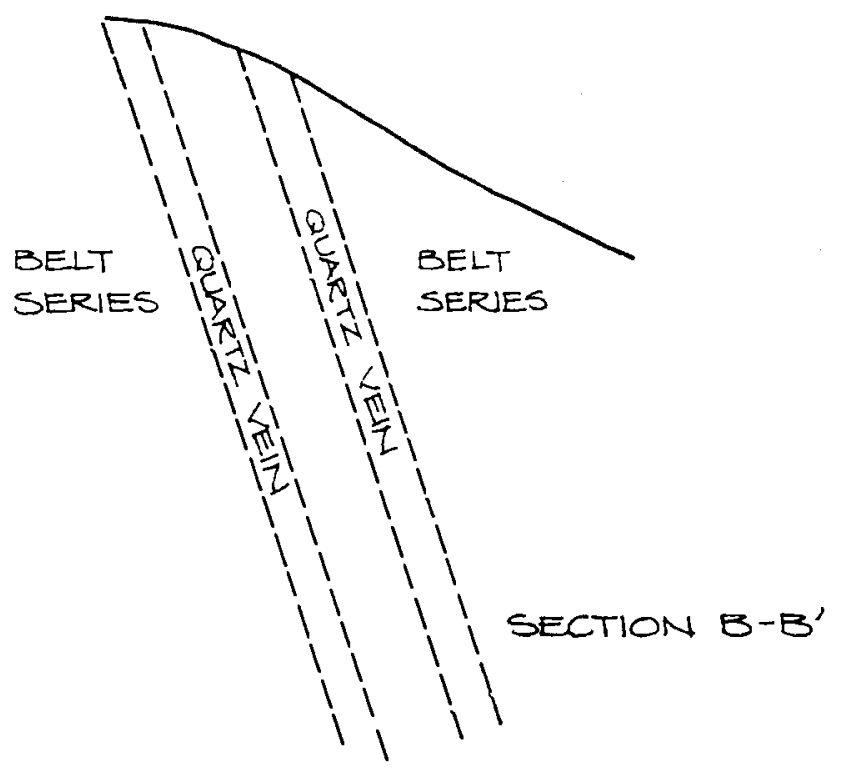

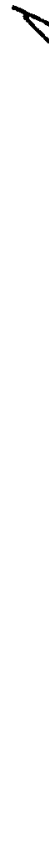
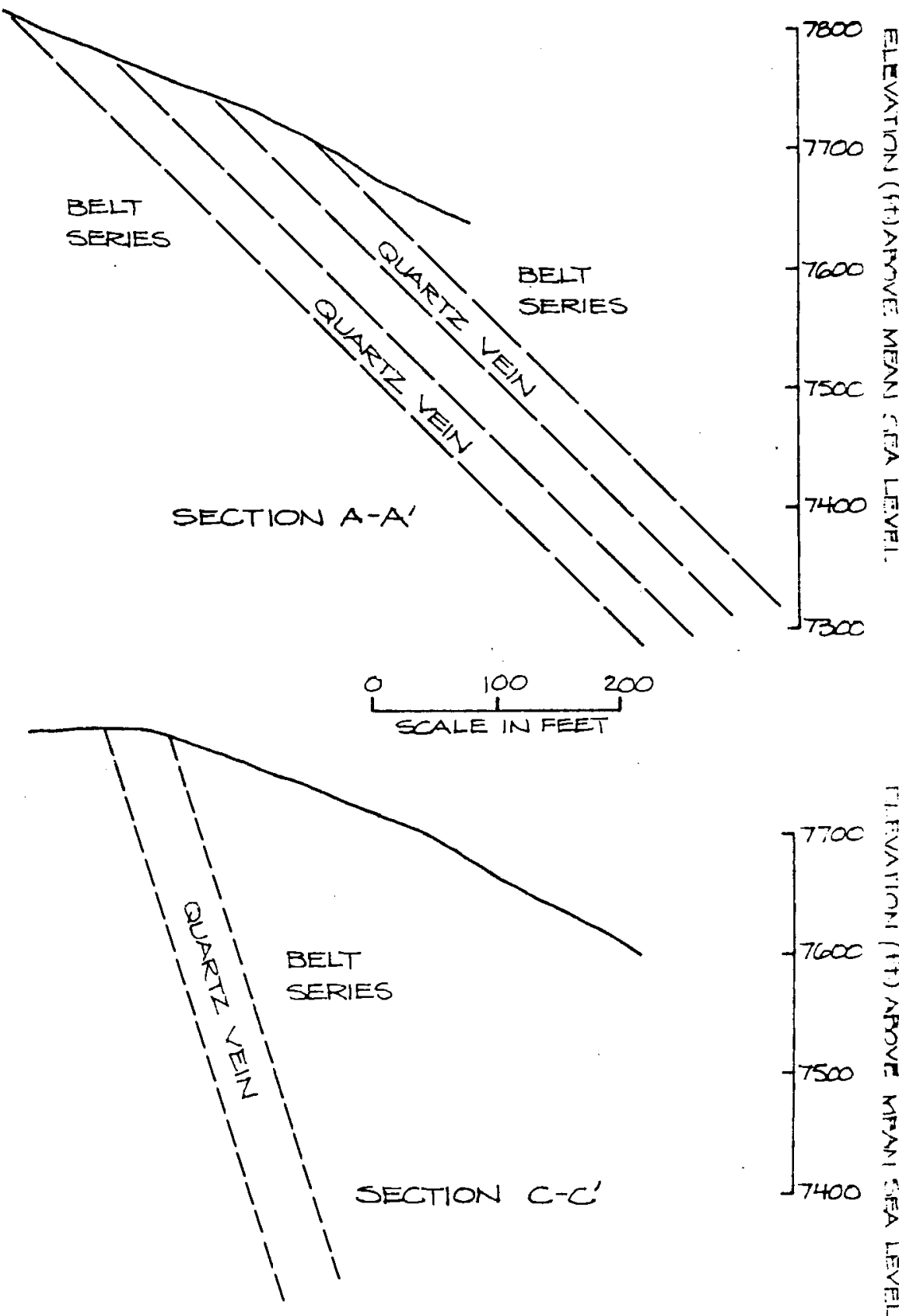
CHAIN PILLAR

SILL PILLAR

$=20.000 \mathrm{~T}$

$=21,000 \mathrm{~T}$

TOTAL LOSS IN PILLARS $=41,000 \mathrm{~T}$

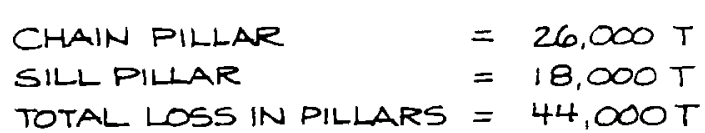

SILL PILLAR

$18,000 \mathrm{~T}$

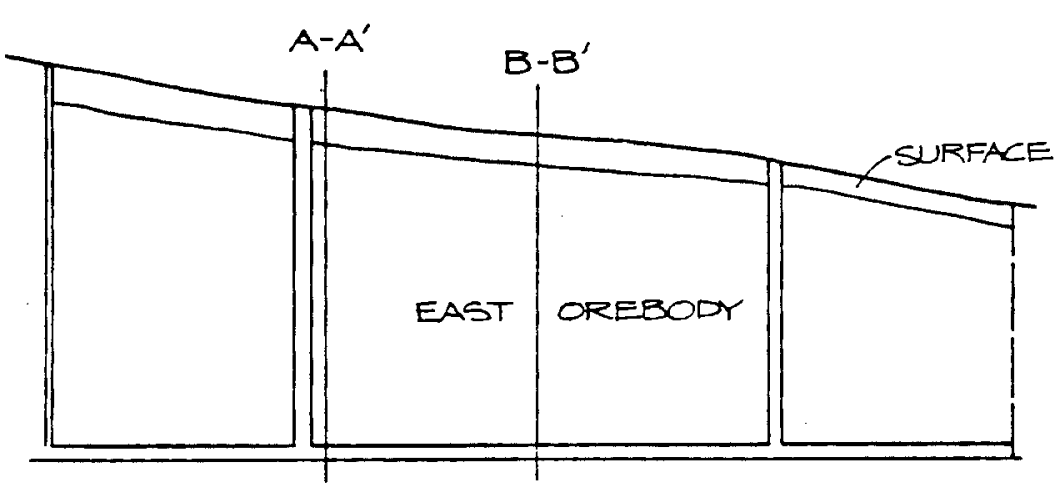

LONGITUDINAL SECTION LUCKY STRIKE NO.I

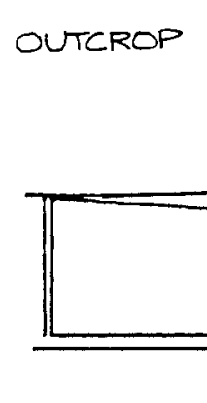

LONGITUDINAL SECTION
TRAPPER NO.I

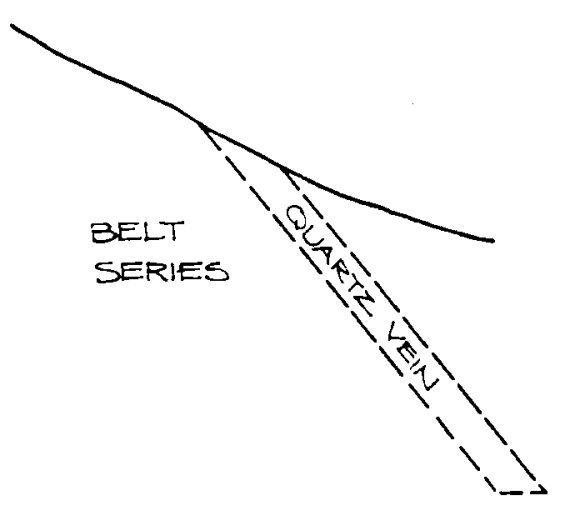

SECTION A-A'

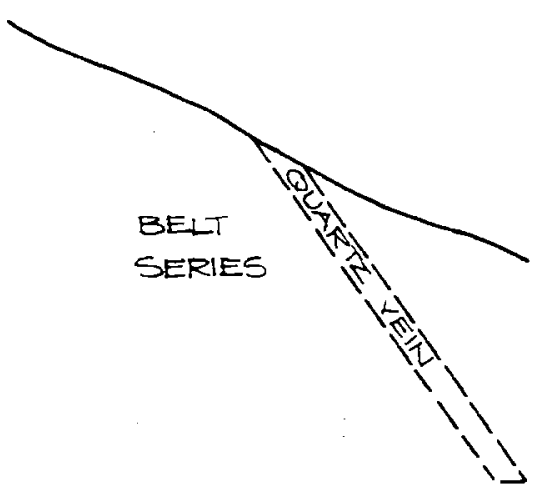

SECTION B-B'

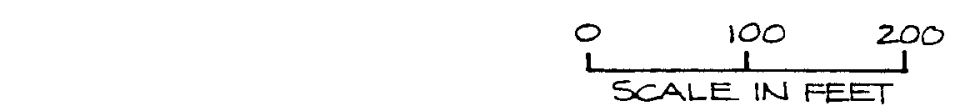

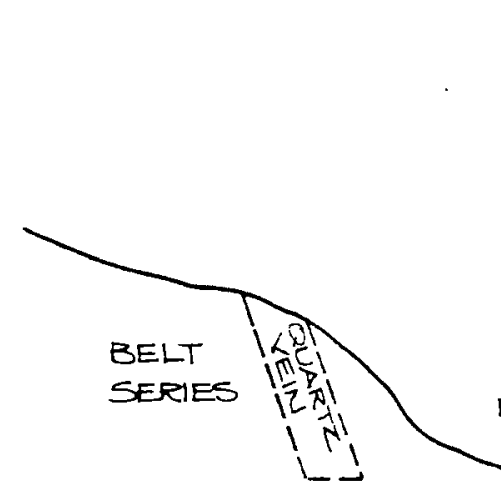

SECTION C-C'

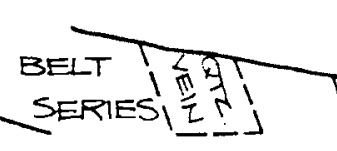

SECTION

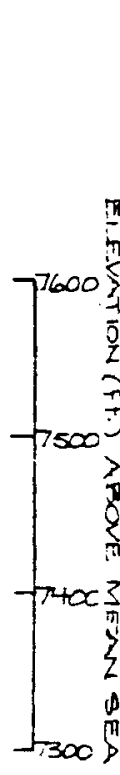

fi 
UHAIN PILLAR SILL PILLAR

$=7000 \mathrm{~T}$

$=2000 \mathrm{~T}$

TOTAL LOSS $I N$ PILLARS $=9000 T$ $\begin{array}{ll}\text { CHAIN PILLAR } & =45,000 \mathrm{~T} \\ \text { SILL PILLAR } & =25,000 \mathrm{~T}\end{array}$

TOTAL LOSS IN PILLARS $=70,000 \mathrm{~T}$

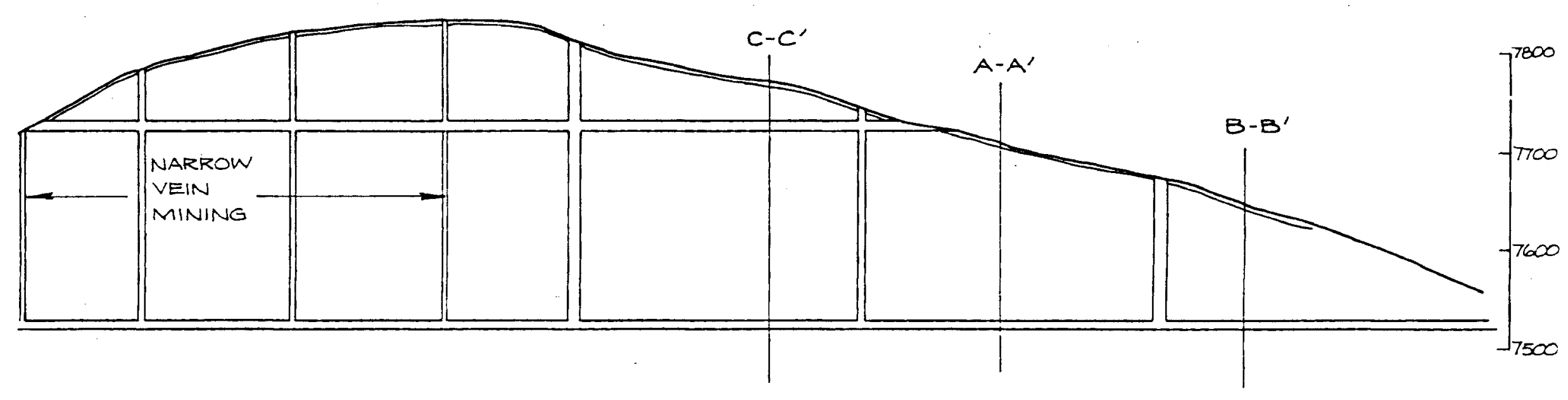

\begin{tabular}{l}
0 \\
$\square$ \\
\hline \\
\hline
\end{tabular}
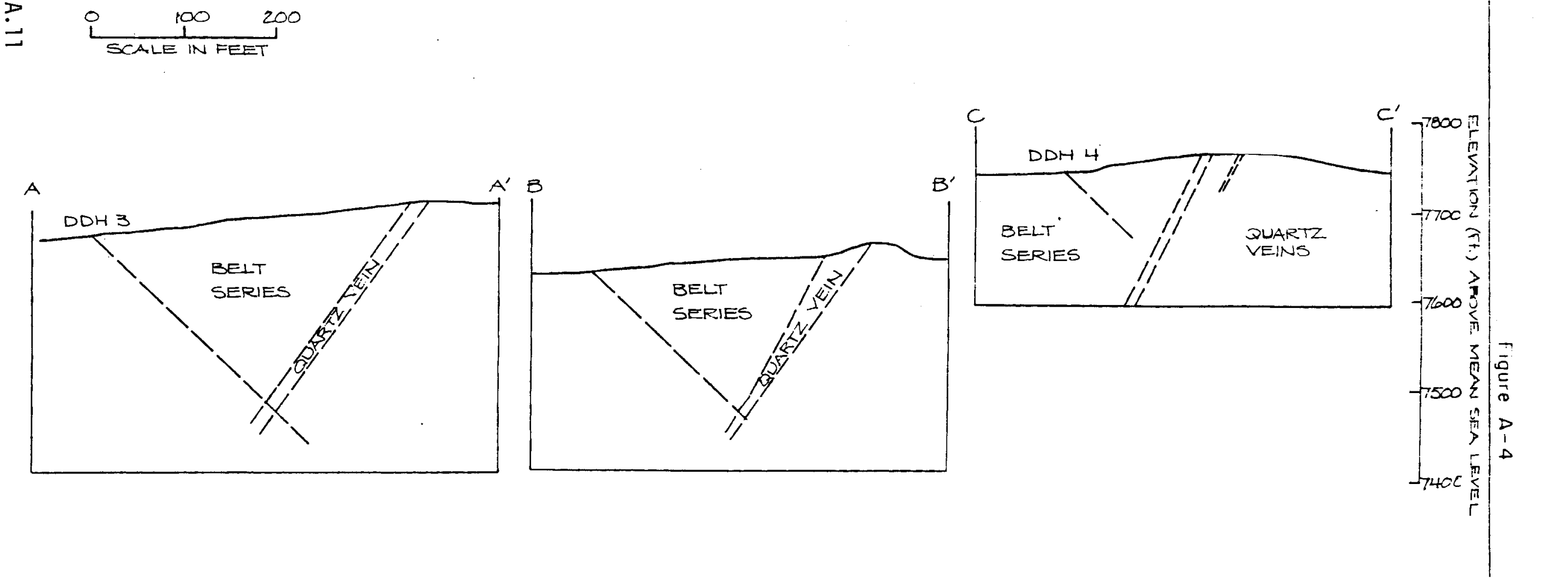
TABLE A4

SUMMARY OF HYPO'THETICAL ORE AND MINING RESERVES

\begin{tabular}{|c|c|c|c|c|c|}
\hline & $\begin{array}{l}\text { Sampled } \\
\text { Grade }\end{array}$ & $\begin{array}{l}\text { Run of } \\
\text { Mine } \\
\text { Grade }\end{array}$ & $\begin{array}{c}\text { Ore } \\
\text { Reserve }\end{array}$ & $\begin{array}{l}\text { Mining } \\
\text { Reserve }\end{array}$ & $\begin{array}{l}\text { Mining } \\
\text { Method }\end{array}$ \\
\hline Vein & $\%$ & $\%$ & Tons & Tons & \\
\hline
\end{tabular}

UPPER BLOCKS

$\begin{array}{lrrrrr}\text { Wonder Lode West } & 0.19 & 0.15 & 28,000 & 19,000 & \mathrm{R} \\ \text { Wonder Lode East } & 1.20 & 0.96 & 21,000 & 18,000 & \mathrm{R} \\ \text { Lucky Strike No.1 East } & 0.02 & 0.02 & 298,000 & 231,000 & \mathrm{CF} \\ \text { Lucky Strike No.1 West } & 0.25 & 0.23 & 254,000 & 208,000 & \mathrm{CF} \\ \text { Trapper No.1 West } & 0.30 & 0.27 & 116,000 & 65,000 & \mathrm{CF} \\ \text { Trapper No.1 East } & 1.45 & 1.31 & 13,000 & 8,000 & \mathrm{CF} \\ \text { Last Chance A } & 0.47 & 0.42 & 329,000 & 233,000 & \mathrm{CF} \\ \text { Last Chance B } & 0.47 & 0.38 & 40,000 & 28,000 & \mathrm{R} \\ & \underline{0.30} & 0.26 & 1,099,000 & 810,000 & \end{array}$

LOWER BLOCKS

\begin{tabular}{lllllll} 
Lucky Strike No.1 East & 0.02 & 0.02 & 998,000 & 802,000 & CF \\
Lucky Strike No.1 West & 0.25 & 0.23 & 381,000 & 306,000 & CF \\
Trapper No.1 West & 0.30 & 0.27 & 818,000 & 659,000 & CF \\
Trapper No.1 East & 1.45 & 1.31 & 152,000 & 122,000 & CF \\
Last Chance A & 0.47 & 0.42 & 923,000 & 746,000 & CF \\
Last Chance B & 0.47 & 0.38 & 123,000 & 99,000 & R \\
\cline { 2 - 5 } & $\underline{0.32}$ & 0.28 & $3,395,000$ & $2,734,000$ &
\end{tabular}

From Table A4 it is evident that 810,000 tons of hypothetical ore at a grade of 0.26 percent can be mined from the upper blocks and that 2,734,000 tons of hypothetical ore at a grade of 0.28 percent can be mined from the lower blocks. Overal.l recoveries from these veins are 74 percent and 81 percent for the upper and lower blocks, respectively. 


\section{A6 DEVELOPMEN'T AND CONSTRUCTION}

'The length of development and the number of chutes required to mine each vein were determined from the assumed geometry of the veins, as detailed in Table A5.

T $\triangle B L E \triangle \Lambda 5$

DETERMINATION OF DEVELOPMEN'T AND CONSTRUC'TION QUANTITIES

\begin{tabular}{|c|c|}
\hline $\begin{array}{l}\text { Type of Development/ } \\
\text { Construction }\end{array}$ & Algorithm \\
\hline $11^{\prime} \times 10^{\prime}$ Drift & Strike length $\frac{\text { Vertical Depth }}{200}$ to next \\
\hline Cut and Fill 6'x8' Raise & $\begin{array}{l}\text { integer) } \times 1.25=\text { Length required. } \\
\text { (Strike length to next integer) } x \text { Dip }\end{array}$ \\
\hline Resue $5^{\prime}$ dia. Raise & $\begin{array}{l}\text { length } \times 1.10=\text { Length required. } \\
\frac{\text { Strike length }}{150} \text { to next integer) } \times \text { Dip }\end{array}$ \\
\hline Chutes (Cut and Fill) & $\begin{array}{l}\text { length } \times 1.10=\text { Length required. } \\
\text { (Strike length to next integer) } \times \text { Number }\end{array}$ \\
\hline Chutes (Resue) & $\begin{array}{l}\text { of levels. = Number required. } \\
\frac{(\text { Strike length }}{150} \text { to next integer) } \times \text { Number }\end{array}$ \\
\hline
\end{tabular}

The development and construction quantities estimated for the various veins are summarized in Table $\Lambda 6$. 
TABLE A6

SUMMARY OF DEVELOPMENT AND CONSTRUCTION QUANTITIES

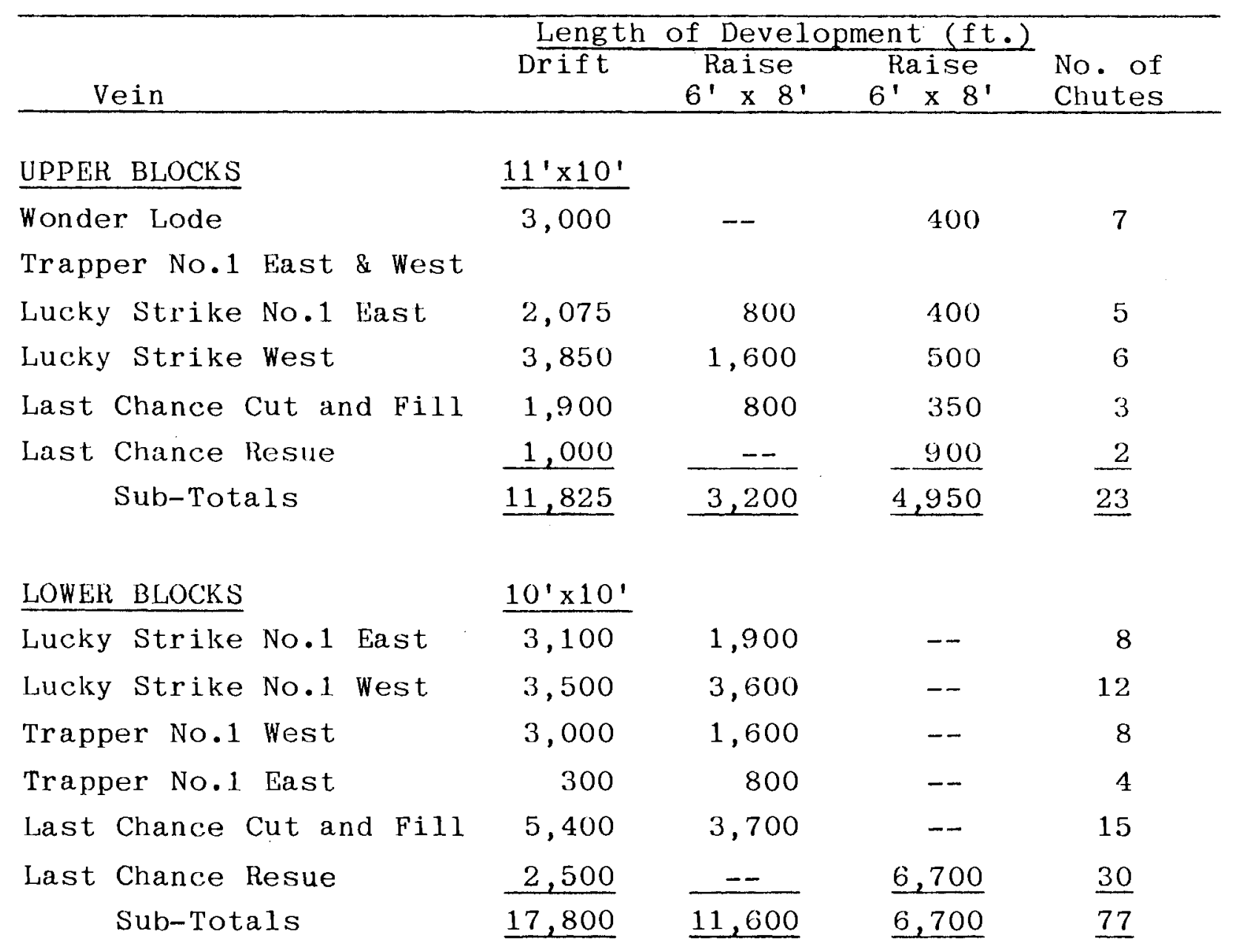


$\underline{\text { Data }}$

$11^{\prime} \times 10^{\prime}$ Trackless Drift

1. Productivity of inanpower - 3.5 feet per manshift, three-man crews.

2. Length of round $10^{\prime}$, actual advance $9^{\prime}$.

3. Explosives used, $51 \mathrm{~b}$. per cubic yard of rock, dynamite or slurry.

4. Two-boom trackless jumbo with $10^{\prime}$ feed, utilized for drilling.

5. Development dirt lashed by a 2-cubic-yard capacity LHD with ejector bucket. Dirt hauled by 10-ton truck with push plate dumping facility .

\section{$10^{\prime} \times 10^{\prime}$ Track Drift}

6. Productivity of manpower - $2 \mathrm{ft}$. per man-shift, 3 man crew.

7. Length of round $10^{\prime}$, actual advance $9^{\prime}$.

8. Explosives used 5 1b. per cubic yard of rock, dynamite, or slurry

9. Two-boom rail jumbo with $10^{\prime}$ feed, utilized for drilling.

10. Air-powered overshot mucker with conveyor belt used for lashing development dirt into granby cars hauled by trolley locomotive.

\section{$6^{\prime} \times 8^{\prime}$ Stulled Raise}

11. Productivity of manpower $-2.75 \mathrm{ft}$. per man-shift, 2 man crew.

12. Length of round $6^{\prime}$, actual advance $5.5^{\prime}$.

13. Explosives used 5.28 1b. per cubic yard of rock, dynamite or slurry

14. Round drilled by hand-held stopers.

5'dia. Bored Raise

15. Productivity of manpower - $6.25 \mathrm{ft}$. per man-shift, 2 man crew.

16. Set up time assumed at three days and drilling time for $200^{\prime}$ raise estimated at five days. 


\section{Construction}

17. Productivity of manpower assumed for chute construction 20 manshifts per chute, including $10^{\prime}$ of $4^{\prime} \times 6^{\prime}$ raise.

18. Portals costed on basis of the additional labor and materials required over and above the standard drifting cost.

19. Dozer time for construction of portals assessed at two shifts for a 50' long portal. Labor for portal construction estimated at 30 man-shifts.

20. Assessment of support necessary for portals is a 6-inch lining of shotcrete over 50: i.e., 28.7 cubic yards per portal.

Costs

1. Estimates of the labor and materials needed for the various types of development are given in Table A7 and details of construction costs are enumerated in Table $\Lambda 8$. 
TABLE A7

ESTIMATED COSTS OF DEVELOPMENT

\begin{tabular}{|c|c|c|c|c|c|c|}
\hline \multirow{2}{*}{$\begin{array}{r}\text { Items } 220,230, \\
240 \text { and } 241\end{array}$} & \multirow[b]{2}{*}{ Units } & \multicolumn{5}{|c|}{$\operatorname{cosTs}(\$)$} \\
\hline & & \multicolumn{2}{|r|}{ Labor } & \multirow[t]{2}{*}{ Supplies } & \multirow[t]{2}{*}{ Total } & \multirow[t]{2}{*}{ Unit } \\
\hline $11^{\prime} \times 10^{\prime}$ Trackless Dr & ift $(220)$ & & & & & \\
\hline Miners & $2.75 \mathrm{M}$ & MS & 231.00 & & 231.00 & 90.00 \\
\hline Drill steels \& bits & $400.00 \mathrm{~L}$ & LF & & 60.00 & 00 & 0.15 \\
\hline Explosives & $203.00 \mathrm{~L}$ & LB & & 122.00 & 122.00 & 0.6 \\
\hline $6^{\prime \prime}$ Air line & $9.00 \mathrm{I}$ & $\mathrm{LF}$ & & 117.00 & 117.00 & 13.0 \\
\hline $2 "$ Water line & $9.00 \mathrm{I}$ & $L F$ & & 22.00 & 22.00 & 2.45 \\
\hline Jumbo & $5.00 \mathrm{H}$ & $\mathrm{HR}$ & 36 & 29.00 & 65.00 & 13.00 \\
\hline LHD & $3.00 \mathrm{H}$ & HR & & 37.00 & 46.00 & 15.25 \\
\hline $10 \mathrm{~T}$ Truck & $2.00 \mathrm{H}$ & $\mathrm{HR}$ & 0 & 13.00 & 18 & 8.6 \\
\hline & & & & er round & $\$ 681$ & \\
\hline $10^{\prime} \times 10^{\prime}$ Track D & $\frac{\text { per foot }}{(230)}$ & $\$ 7$ & 5.00 & & & \\
\hline Miners & $4.50 \mathrm{~N}$ & MS & 405 & & 405.00 & 90.0 \\
\hline Drill steels \& bits & $360.00 \mathrm{I}$ & LF & & 54.00 & 00 & $0.1:$ \\
\hline Explosives & $185.00 \mathrm{I}$ & LB & & 111.00 & 111 & 0.6 \\
\hline 6" Air line & $9.00 \mathrm{~L}$ & LF & & & 117 & \\
\hline 2" Water line & $9.00 \mathrm{I}$ & LF & & 22.00 & 00 & 2.45 \\
\hline Rail & $18.00 \mathrm{I}$ & LB & & 108 & 108 & \\
\hline Ties & $3.00 \mathrm{E}$ & $\mathrm{EA}$ & & 24 & 00 & \\
\hline Track Miscellaneous & $9.00 \mathrm{I}$ & LF & & 9.00 & 9.00 & 1.0 \\
\hline Jumbo & $4.50 \mathrm{l}$ & $\mathrm{HR}$ & & 20.00 & 47.00 & 10 \\
\hline Loader & $00 \mathrm{H}$ & $\mathrm{HR}$ & & 20.00 & 44.00 & 11.0 \\
\hline 'Trolley Locomotive & $6.00 \mathrm{l}$ & HR & & 33.00 & 71.00 & 11.75 \\
\hline Granby cars & $20.00 \mathrm{l}$ & $\mathrm{HR}$ & 16.00 & 16.00 & 32.00 & 1.6 \\
\hline
\end{tabular}

Cost per foot $\$ 116.00$

$6^{\prime} \times 8^{\prime}$ Stulled Raise (241)

$\begin{array}{lrrrrr}\text { Miners } & 2.00 \mathrm{MS} & 180.00 & & 180.00 & 90.00 \\ \text { Drili steels \& bits } & 200.00 \mathrm{LF} & & 20.00 & 20.00 & 0.10 \\ \text { Explosives } & 50.00 \mathrm{LB} & & 30.00 & 80.00 & 0.60 \\ 4 " \text { Air line } & 5.50 \mathrm{LF} & & 33.00 & 33.00 & 6.00 \\ \text { 1" Water line } & 5.50 \mathrm{LF} & & 6.00 & 6.00 & 1.00 \\ \text { Timber } & 200.00 \mathrm{BF} & & 40.00 & 40.00 & 0.20 \\ \text { Ladders } & 11.00 \mathrm{LF} & & 33.00 & 33.00 & 3.00 \\ \text { Stoper } & 7.00 \mathrm{HL} & 21.00 & 24.00 & 45.00 & 6.50 \\ & & & \text { Cost per round } & \$ \$ 387.00 & \end{array}$

Cost per foot $\$ 70.00$

5' dia. Bored Raise (240)
Miners
32.00 MS $2,880.00$
$2,880.00 \quad 90.00$
Cutters
$3,927.00 \mathrm{CuFt} \quad 5,890.00$
$5,890.00 \quad 1.50$
Raise Borer
$80.00 \mathrm{HR} 1,808.002,140.00 \quad 3,948.00 \quad 49.35$
Cost per foot $\$ 64.00$
Cost per round $\$ \overline{12,718.00}$ 
TABLE A8

ESTIMATED COSTS OF CONSTRUCTION

\begin{tabular}{|c|c|c|c|c|c|}
\hline \multirow{2}{*}{ ITEMS 223,250} & \multicolumn{5}{|c|}{ COSTS $(\$)$} \\
\hline & UN ITS & LABOR & SUPPLIES & TO'TAL & UN IT \\
\hline \multicolumn{6}{|l|}{ Chutes $(250)$} \\
\hline Chute Raise & $10.00 \mathrm{LFF}$ & 200.00 & 90.00 & 290.00 & 29.00 \\
\hline Labor & $20.00 \mathrm{MS}$ & $1,800.00$ & & $1,800.00$ & 90.00 \\
\hline Chute Timber & & & 454.00 & 454.00 & \\
\hline Air Cylinder & & & $1,000.00$ & $1,000.00$ & $1,000.00$ \\
\hline Rollers & $8.00 \mathrm{EA}$ & & & 160.00 & 20.00 \\
\hline Used Rail & $100.00 \mathrm{LF}$ & & & 400.00 & 4.00 \\
\hline \multirow{2}{*}{\multicolumn{6}{|c|}{$\begin{array}{l}\text { Misc. Hardware } \\
\text { \& Pipe Fittings }\end{array}$}} \\
\hline & & & 500.00 & & \\
\hline Misc. Timber & $200.00 \mathrm{BF}$ & & & $\begin{array}{r}40.00 \\
\$ 4,644.00 \\
\end{array}$ & 0.20 \\
\hline & $\underline{\text { Cost }}$ & er chute & $\$ 4,644.00$ & & \\
\hline \multicolumn{6}{|l|}{ Porta1s (223) } \\
\hline Shotcrete & $28.70 \mathrm{CY}$ & 795.00 & 640.00 & $1,435.00$ & 50.00 \\
\hline Miners & $30.00 \mathrm{MS}$ & $2,700.00$ & & $2,700.00$ & 90.00 \\
\hline Dozer & $16.00 \mathrm{HR}$ & 310.00 & 268.00 & $\begin{array}{r}578.00 \\
\$ 4,713.00 \\
\end{array}$ & 36.15 \\
\hline
\end{tabular}




\section{A.7 OPERATING COSTS}

Ventilation

1. Each working place must be supplied with air at a velocity of $100 \mathrm{f} \cdot \mathrm{p} . \mathrm{m}$.

On this basis, cut and fill stopes require $10,000 \mathrm{cfm}$ per stope; resue stopes 6,000 cfm each; drifts $11,000 \mathrm{cfm}$ each .

2. A brief summary of the ventilation requirements for the mine are enumerated in Table A9.

TABLE A9

SUMMARY OF VENTILATION REQUIREMENTS

\begin{tabular}{|c|c|c|c|c|}
\hline Working Place & $\begin{aligned} \text { Total } & \text { Air } \\
\text { Quantity } & \text { c.f.m. }\end{aligned}$ & Fans & Required & $\begin{array}{l}\text { Tota1 } \\
\text { Power }\end{array}$ \\
\hline $\begin{array}{l}\text { Cut and Fill stopes ( } 8) \\
\text { Resue stopes ( } 4) \\
\text { Drifts and raises (6) } \\
\text { Workshops, etc. } \\
\text { Miscellaneous }\end{array}$ & $\begin{array}{l}80,000 \\
24,000 \\
66,000 \\
10,000 \\
25,000\end{array}$ & $\begin{array}{ll}8 & x \\
4 & x \\
6 & x \\
4 & x \\
5 & x\end{array}$ & $\begin{array}{ll}20 & \mathrm{H} . \mathrm{P} . \\
10 & \mathrm{H} . \mathrm{P} . \\
20 & \mathrm{H} . \mathrm{P} . \\
10 & \mathrm{H} . \mathrm{P} . \\
10 & \mathrm{H.P} .\end{array}$ & $\begin{array}{r}160 \\
80 \\
120 \\
40 \\
50 \\
\end{array}$ \\
\hline & 205,000 & & & 450 \\
\hline
\end{tabular}

3. Leakage assessed at 30 percent of total air quantity.

4. Ventilation ducting purchased as capital equipment.

Tramming

Trackless Haulage

1. Requirements based on: $4 \mathrm{~m} \cdot \mathrm{p} \cdot \mathrm{h}$. traveling speed; 4 minute fixed journey time; 10-ton load; 50 minute hour. Thus, 1,500 feet hauling productivity is approximately 40 tons per hour, or 260 tons per shift.

2. Three 10-ton trucks are needed for the Wonder, Last Chance and Trapper-Lucky Strike veins owing to the distance between portals. 
3. 'Trucks used for supply when not hauling.

4. Productivity would, therefore, be at a production rate of 500 tons per shift, 167 tons per machine shift.

5. Labor cost $\$ 316$ per shift, supplies $\$ 123$ per shift, thus cost per 500 tons is $\$ 439$ or $\$ 0.88$ per ton hauled.

Rail Haulage

1. The decision to utilize rail haulage on the main 6600 level was based on the large tonnages and long haul distances involved ('Table A10).

TABLE A10

HAUL DISTANCES AND TONNAGE OF LOWER BLOCKS

\begin{tabular}{lrrr}
\hline \multirow{2}{*}{ Vein } & \multicolumn{1}{c}{ Mining } & \multicolumn{2}{c}{ Haul Distances (feet) } \\
\cline { 4 - 4 } Reserve (tons) & Average & Longest \\
Last Chance & 369,000 & 1,000 & 1,500 \\
Lucky Strike E & 298,000 & 1,250 & 1,500 \\
Lucky Strike W & $1,980,000$ & 2,100 & 2,400 \\
Trapper & 129,000 & 500 & 950 \\
Wonder & 49,000 & 400 & 1,100 \\
\hline
\end{tabular}

2. A factor of 174 minutes travel time per shift is estimated for a speed of $528 \mathrm{fpm}$ to haul 500 tons, i.e. seven trips per shift with 71 ton loads.

3. Ten-ton loco required to haul 10 7-ton granbies.

4. Breakdown of rail haulage costs are listed in Table AIl. 
'LABILA Al

ESTIMATED COS'IS OF RAIL HAULAGE

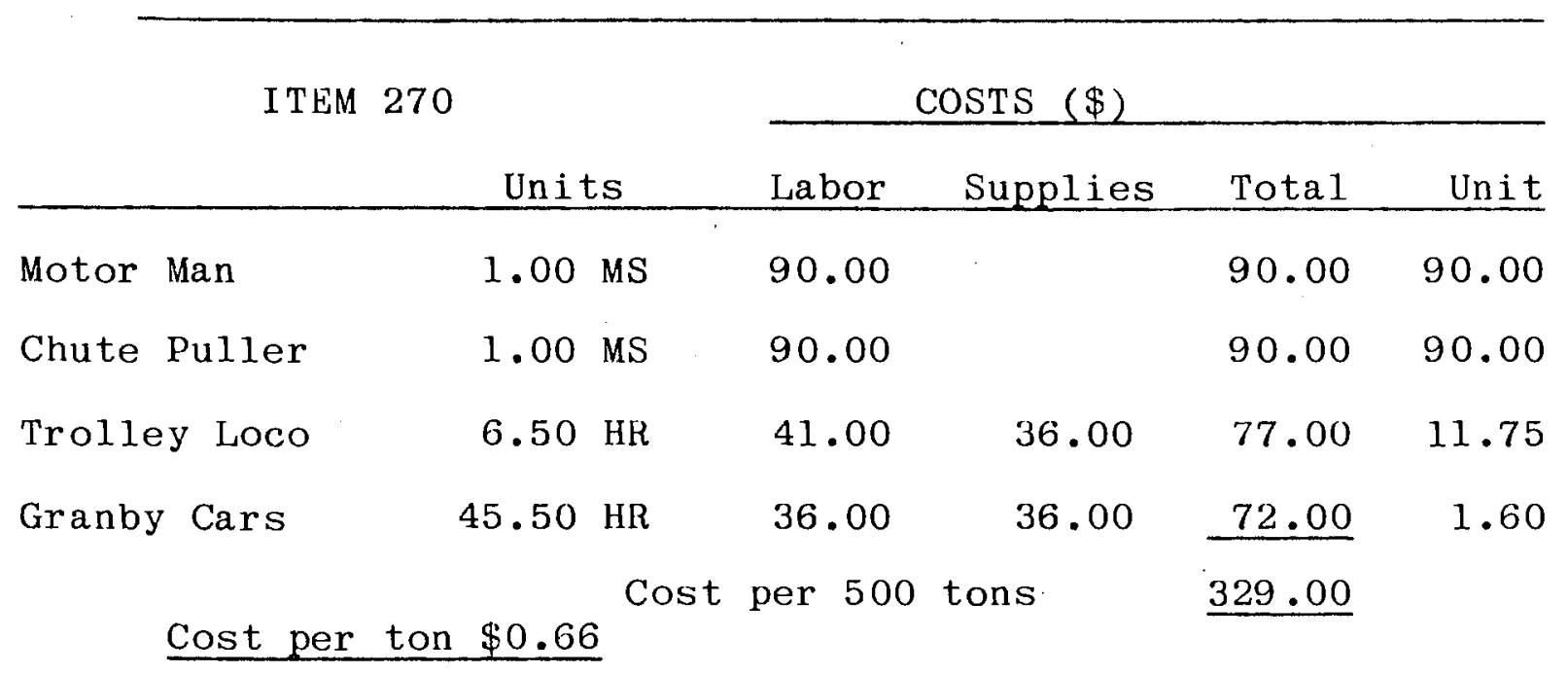

Compressor Plant

1. The 10,000 cfm quantity of compressed air necessary to operate the air-powered equipment in the mine was based on the estimates of consumption for the various activities. These consumptions are summarized in Table A12.

TABLE A12

SUMMARY OF COMPRESSED AIR REQUIREMENTS

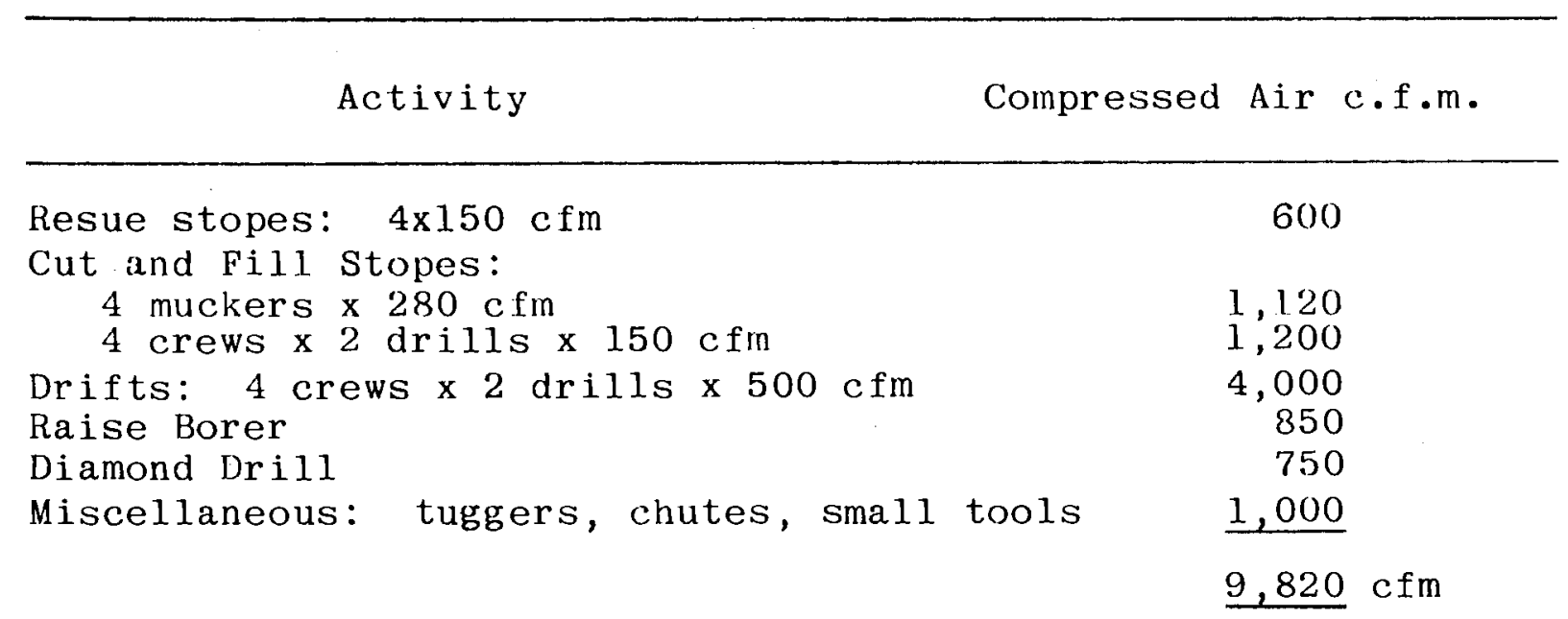


2. Diversity factor for 30 operating pieces of equipment

$=\frac{23.5}{30}=0.78$.

Altitude multiplier $=1.22$.

$$
\begin{aligned}
& \text { Estimated consumption }=9,820 \times 1.22 \times 0.78 \mathrm{cfm} \\
&=9,285 \mathrm{cfm} \\
& \text { Rounded up to } 10,000 \mathrm{cfm}
\end{aligned}
$$

3. Power requirements for compressor plant can be estimated from a factor of 20 brake horsepower per $100 \mathrm{cfm}$. Thus $2,000 \mathrm{HP}$ synchronous motor is needed to produce $10,000 \mathrm{cfm}$.

4. Power cost of motor can be calculated as follows:

$$
\begin{aligned}
& 2,000 \times 0.746 \times \$ 0.025 \times 1 / 1=\$ 37.30 / \mathrm{HR} . \\
& \text { Cost per annum }=\$ 149,200
\end{aligned}
$$

5. Power cost of motor represents $65 \%$ of the running costs of a compressor plant compared to $20 \%$ for operating charges and $15 \%$ for fixed charges and repairs. Thus:

$$
\begin{array}{ll}
\text { Power cost } 65 \% & \$ 149,200 / \mathrm{YR} . \\
\text { Operating charges 20\% } & \$ 46,000 / \mathrm{YR} . \\
\text { Fixed charges and repairs 15\% } & \$ 34,000 / \mathrm{YR} .
\end{array}
$$

Annual operating cost $\$ 229,200 / Y R$.

\section{Electricity Supply}

1. The annual power costs per annum at a production rate of 250,000 tons per year are 1 isted in Table $\Lambda 13$. 
TABI.E $\mathrm{A} 13$

$\triangle$ NNUAL POWER COSTS

Item

Annual Costs $\$$

Ventilation fans ( 0.80 power factor)

Tramming

Lighting Underground

Slushers \& heaters ( 0.80 power factor)

Compressor plant

Lighting surface, heaters, etc.

$$
\begin{aligned}
& 92,000 \\
& 6,400 \\
& 21,900 \\
& 20,000 \\
& 149,200 \\
& 20,000 \\
& \text { Sub Tota1 } 309,500 \\
& 340,000 \text { per year }
\end{aligned}
$$

\begin{tabular}{|c|c|c|c|c|}
\hline Personnel & Vehicle & $\begin{array}{c}\text { Estimated } \\
\text { Miles } \\
\text { Per Year } \\
\end{array}$ & $\begin{array}{l}\text { Cost } \$ \\
\text { Per Mile }\end{array}$ & $\begin{array}{l}\text { Cost } \$ \\
\text { Per Year }\end{array}$ \\
\hline $\begin{array}{l}\text { Mine Manager } \\
\text { Superintendent } \\
\text { Foreman } \\
\text { Foreman } \\
\text { Personnel (from Dillon) } \\
\text { Personnel (from Dillon) } \\
\text { Personnel (from Salmon) } \\
\text { Supplies }\end{array}$ & $\begin{array}{l}\text { Saloon } \\
\text { Pick-up } \\
\text { Pick-up } \\
\text { Pick-up } \\
\text { Bus } 1 \\
\text { Bus } 2 \\
\text { Bus } 3 \\
\text { 5'T I'ruck }\end{array}$ & $\begin{array}{l}52,000 \\
22,500 \\
22,500 \\
16,250 \\
45,000 \\
45,000 \\
30,000 \\
20,800\end{array}$ & $\begin{array}{l}0.21 \\
0.21 \\
0.21 \\
0.21 \\
0.50 \\
0.50 \\
0.50 \\
0.50\end{array}$ & $\begin{array}{r}10,920.00 \\
4,725.00 \\
4,725.00 \\
3,410.00 \\
22,500.00 \\
22,500.00 \\
15,000.00 \\
10,400.00\end{array}$ \\
\hline & & & & $\$ 94,180.00$ \\
\hline
\end{tabular}$$
\text { Contingencies } \quad 30,000
$$

\section{Transportation}

1. The provision of transport facilities for the staff and personnel is detailed in Table A.14 together with the assumed running costs.

TABLE $\quad$ A14

OPERATING COSTS OF PEIRONNEL AND SUPPLIES TRANSPORT 
2. Mileages for the buses were calculated on the assunption of a 250-day year and two journeys per day.

\section{Hourly Equipment Costs}

1. The basis for the hourly equipment costs charged to the various cost centers is outlined in Table Al4.

TABLE $\quad 414$

HOURLY EQUIPMENT COSTS

I TEM

COSTS $(\$) /$ HOUR

\begin{tabular}{|c|c|c|c|c|c|}
\hline Repair & Filter, & Repair & Total & Tota 1 & Total \\
\hline Supplies & $\begin{array}{l}\text { Lube, } \\
\text { 'ires, }\end{array}$ & Labor & Supplies & Labor & Cost \\
\hline
\end{tabular}

$\begin{array}{lrrrrrr}\text { LHD 2 Cubic Yard } & 3.00 & 9.25 & 3.00 & 12.25 & 3.00 & 15.25 \\ \text { l0-Ton Haul Truck } & 2.35 & 3.95 & 2.35 & 6.30 & 2.35 & 8.65 \\ \text { Trackless Jumbo } & 4.40 & 1.40 & 7.20 & 5.80 & 7.20 & 13.00 \\ \text { Jacklegs \& Stopers } & 3.00 & 0.50 & 3.00 & 3.50 & 3.00 & 6.50 \\ \text { Raise Borer } & 21.10 & 5.65 & 22.60 & 26.75 & 22.60 & 49.35 \\ \text { 1.75-Ton Loader } & 4.15 & 1.00 & 5.85 & 5.15 & 5.85 & 11.00 \\ \text { Granby Car 135 cf } & 0.75 & 0.05 & 0.80 & 0.80 & 0.80 & 1.60 \\ \text { Trolley Loco 11 Ton } & 5.10 & 0.40 & 6.25 & 5.50 & 6.25 & 11.75 \\ \text { Slusher 2 Drum 15 HP } & 2.50 & 1.00 & 2.50 & 3.50 & 2.50 & 6.00 \\ \text { D8 Dozer } & 10.00 & 6.75 & 19.40 * & 16.75 & 19.40 & 36.15 \\ \text { Rail Jumbo } & 3.50 & 1.00 & 6.00 & 4.50 & 6.00 & 10.50 \\ \text { Mucker } & 4.00 & 1.00 & 6.00 & 5.00 & 6.00 & 11.00 \\ \text { Boss Buggy U/G } & 2.50 & 4.00 & 2.50 & 6.50 & 2.50 & 9.00 \\ \text { Diamond Dril1 } & 2.00 & 3.00 & 2.00 & 5.00 & 2.00 & 7.00\end{array}$

* Includes Operating $(\$ 11.60 / \mathrm{HR})$ and Service $(\$ 2.80 / \mathrm{HR})$ Labor. 


\section{Indirect Operating Costs}

The indirect operating costs for the life of the mine amount to $\$ 19,726,159$ (Tables $A 16$ and $A 17$ ). The indirect costs for the first seven years of production are greater than the latter half of the mine life since development and exploration activities are carried out during the initial years of production. 


\section{A8 CAPITAL COSTS}

1. The estimate of expenditure for capital equipment is based on approximate costs, free on rail, given by some of the major mining equipment manufacturers.

2. Building costs are estimates made on the basis of $\$ 15$ per square foot of the approximate area required.

3. The mine life is assumed to be 14 years for capital items normally written off over the working life of a mine.

4. Equipment ordinarily due for replacement within the 13 th and 14 th years of production have not been replaced. 
APPENDIX E

PALMER, MICHIGAN MODEL MINE/MILL

This appendix contains a report completed for PNL by a consulting agency. 



\title{
Golder Associates
}

CONSULTING MINING AND GEOTECHNICAL ENGINEERS

\author{
REPORT TO \\ BATTELLE-PACIFIC NORTHWEST LABORATORIES \\ FOR \\ MINING AND MILLING A THORIUM-BEARING QUARTZITE \\ AT PALMER, MICHIGAN \\ BY OPEN PIT METHODS
}

Distribution:

3 copies - Battelle-Pacific Northwest Laboratories

3 copies - Golder Associates, Inc.

S78008

June 1978 

1.0 INTRODUCTION

2.0 GENERAL DESCRIPTION OF THE PALMER AREA

2.1 Location

2.2 Geography

2.3 Clinate

3. 0 GEOLOGY

3.1 General - Palmer Area

3.2 The Goodrich Quartzite

3.2 .1 General

3.2.2 Shape and Thorium Content

3.2.3 Upper Part of the Central Area

3.2.3.1 Mining Geology and Pit Design

3.2.3.2 Concentrator Recoverability

4.0 DEVELOPMEN'T SCHEDULE

\subsection{General}

4.2 Exploration Phase

4.2.1 Purpose

4.2.2 Details

4.3 Pre-Mine Development Phase

4.3.1 Purpose

4.3.2 Details

4.4 Construction Phase

4.4.1 Purpose

4.4.2 Details

4.5 Operational Phase

4.5.1 Purpose

4.5.2 Details

4.5.2.1 Mine Operations

4.5.2.2 Mill Operations

5.0 COST SUMMARY

APPENDIX A. COST ESTIMATES

B. MINE EQUIPMENT SELECTION

C. SUMMARY OF MAJOR ASSUMPTIONS USED IN STUDY 


\section{LIST OF FIGURES}

1. Index Map Showing Location of the Palmer Area, Michigan.

2. Contour Map of Conceptual Orebody.

3. Pit 1 .

4. Pit 2 .

5. Pit 3 .

6. Bedrock Geology.

7. Cross Sections.

8. Deadwood Conglomerate, Bald Mountain, Wyoming: Materials Balance Laboratory Test.

9. Goodrich Quartzite, Palmer, Michigan: Materials Balance for a Conceptual Mill.

10. Development Schedule.

\section{LIST OF TABLES}

1. Ore and Waste in Pits 1,2 and 3 .

2. Mine Excavation Schedule.

3. Cost Summary.

A1 Fixploration Phase Costs.

A2 Pre-Mine Development Phase Costs.

A3 Construction phase Costs.

A4 Operational Phase Mill Costs.

A5 Operational Phase Mine Costs. 


\subsection{INTRODUCTION}

This report examines the estimated costs of mining and concentrating the thorium-bearing mineral monazite from a rock formation known as the Goodrich Quartzite, which occurs under and around the town of Palmer, Michigan.

The amount of monazite contained in the Goodrich Quartzite and the amount of thorium contained in the monazite have been inferred only from very scanty data and from tests made and reported in the mid 1950's. These inferred percentage amounts have been used as a basis for this study. As the Goodrich Formation is near the surface, open pit mining methods were considered.

The mining and milling process would end with the production of a concentrate largely containing monazite which would be loaded into rail cars for shipment to a refinery. The overall process would start with the advance stripping of waste glacial till and rock to expose the thorium-bearing portions of the Goodrich Formation. This stripping of waste and the subsequent mining of ore would be done by large electric shovels loading into mining trucks. The Goodrich Quartzite is a hard rock and would have to be broken prior to loading by drilling and blasting. The waste would be hauled to a waste dump and the ore to a concentrator, where the monazite component of the ore would be separated. The remaining gangue would be slurried to a tailings storage area.

In order to obtain a more complete estimate of the costs of this process and the work required to bring a mine into production, an exploration, pre-mine development, construction, and operational schedule was formulated. The costs of each of 
these components were estimated and then broken into annual sums.

The schedule was divided into pre-revenue and revenue periods (revenue is assumed to commence when the mill is onstream producing concentrate). Ten years of pre-revenue activity were allocated to explore and develop the Goodrich Quartzite, and to construct the concentrator and mine buildings. The annual production rate from the mine during the revenue years was set to give it approximately twenty years of operational life.

Because of the general level of uncertainty that is associated with the grade, grade distribution, and concentrating characteristics of this deposit, order-of-magnitude cost estimates have been used. These are based on current industrial experience in processes most relevant to those envisioned as being applicable to the recovery of thorium in the Goodrich Quartzite. 


\subsection{GENERAL DESCRIPTION OF THE PALMER AREA}

\subsection{Location}

The Palmer area is in the east-central portion of Marquette County, Michigan, which occupies a part of the northern penninsula of Michigan (see Pigure 1). The town of Palmer is located about 10 miles southeast of the iron-ore shipping port of Marquette. The area is served by a network of good highways and railroads. The population of Palmer is approximately 800 according to Marquette County officials.

The general area of interest is approximately 4 miles in length and .75 miles in width. It occupies parts of sections 27 through 34, T47N, $\mathrm{R} 26 \mathrm{~W}$, and includes the town of Palmer. The Palmer area is part of a major iron-mining region. Three miles north of the area is Negaunce, site of the first discovery of iron ore in the Lake Superior region. About 1 mile northwest of the Palmer townsite is the Empire iron mine, which currently produces 5.2 million tons per year (tpy) of iron pellets. A 250 million dollar expansion program is underway to expand this to 8 miliion tpy by 1980 .

\subsection{Geography}

The Palmer area is characterized by relatively rugged, knobby topography, and is covered by a dense second-growth forest. Elevations range from 1,160 feet above sea level in the southeast to a maximum of 1,780 feet about 1.5 miles northwest of Palmer. The most prominent topographic reliefs are the Kona Hills and Wewe Hills to the northeast, and a small belt of hills north and south of Palmer. To the east is an extensive sand plain. 


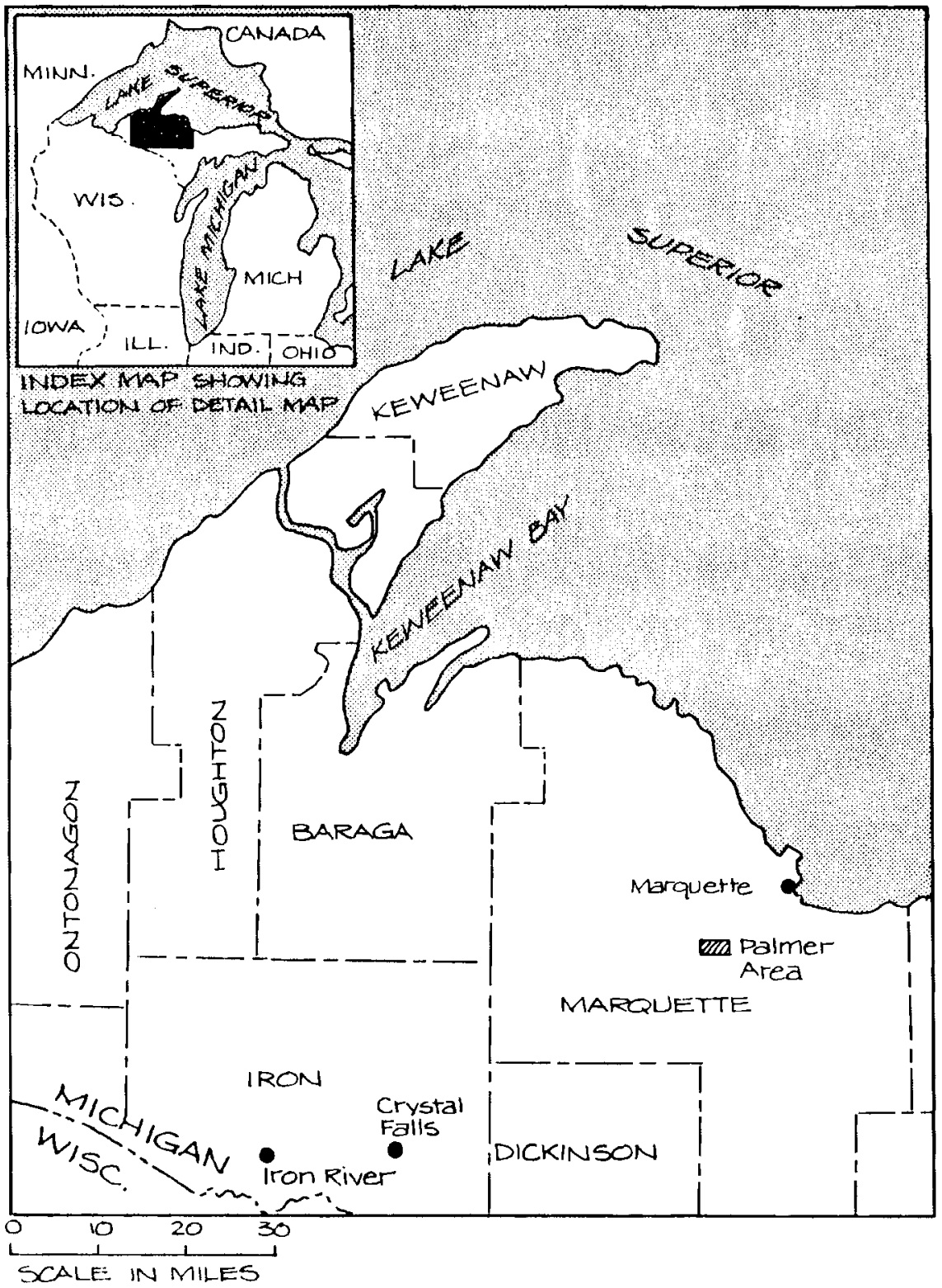


The area is entirely within the Lake Michigan drainage basin, and the localized drainages have a distinctive southeastward configuration. The largest stream is the East Branch of the Escanaba River, which forms from the confluence of Warner and Schweitzer Creeks and flows southeastward to Lake Michigan. The Goose Lake system drains the areas to the northeast and east. Small swamps occur in widely different elevations in much of the area.

\section{$2.3 \quad$ Climate}

The nearest climatological stations which are operated and maintained by the National Oceanic and Atmospheric Administration, U.S. Environmental Data Service, are located in downtown Marquette (latitude $46^{\circ} 34^{\prime}$ north, longitude $87^{\circ} 24^{\prime}$ west elevation 677 feet above sea level), and about 8 miles south at the Marquette Airport (latitude $46^{\circ} 32^{\prime}$ north, longitude $87^{\circ} 34^{\prime}$ west, elevation 1,415 feet above sea level). Detailed tables giving normals, means, and extremes of the various weather data collected by these stations are available from NOAA.

The following excerpt from a 1963 summary gives the salient climatolical features of the region:

\footnotetext{
"Based on the record to 1963 for the downtown Marquette station, the average data of the last occurrence of freezing temperatures in spring is May 14 and the average data of the first freezing temperature in autumn is October 20. The length of the growing season ranges between 134 and 182 days and averages 159 days annually. The warmest year on record was 1931 with an average annual temperature of $46.8^{\circ} \mathrm{F}$, and the coldest year was 1885 with
} 
an average temperature of $36.6^{\circ} \mathrm{F}$. Precipitation is rather evenly distributed throughout the year, there being no pronounced wet or dry periods. Total Precipitation for the driest year on record, 1925, was 19.68 inches and for the wettest year, 1881, 42.70 inches. Snowfall is heavy, exceeding 100 inches in 7 out of every 10 winter seasons. 'The greatest snowfali on record for any winter was 189.1 inches during the 1890-91 season, followed closely by the winter of 1959-60 with 188.1 inches and that of 1949-50 with 188.0 inches. Least snowfall for any seasn was 53.4 inches in 1940-41. The greatest depth of snow on the ground was 48.6 inches and occurred on Januay 2, 1911." (U.S. Department of Commerce, Weather Bureau, 1963). 


\subsection{GEOLOGY}

3.1 General - Palmer Area

The geology of the area surrounding Palmer is thoroughly covered in U.S. Geological Survey Professinal Paper 769 on "Bedrock Geology and Ore Deposits of the Palmer Quadrangle, Marquette County, Michigan" by Jacob E. Gair, 1975. The ore deposits mentioned in the title are iron deposits; the thorium-bearing Goodrich Quartzite is of minor importance within the intent of that publication.

\subsection{The Goodrich Quartzite}

\subsubsection{Genera1}

The Goodrich Quartzite in the Palmer area is composed of a locally-developed basal conglomerate which grades upward into interbedded quartzites and conglomerates. The lithology of the basal conglomerate varies with the character of the subjacent Negaunne Formation. The basal portion of the Goodrich is composed almost entirely of boulders and pebbles of granite. Above the basal unit, the Goodrich Quartzite consists of alternating beds of coarse quartzite and pebble conglomerate. Thicknesses of the observed conglomerate beds or lenses range from approximately 2 inches to 2 feet. The separating quartzite beds of coarse sand range from 1 to 30 feet in thickness. The observed relationships in this area are limited to outcrops which represent only the lower 200 feet of the formation.

The maximum thickness of the Goodrich Quartzite has not been determined. Three diamond drill holes penetrated approximately., 100 feet of the Goodrich, but no younger formations were encountered (Vickers 1956). 
The monazite concentrations are associated with the pebble conglomerates. Only the upper 700 feet of the three diamond dri11 holes were gamma-ray logged. The lower portion of these holes exceeded the length of cable available for the gamma ray probe. These logs show a general increase in radioactivity in the upper and middle portions of the formation. This led Vicker's (1956) and Gair (1975) to assume that the percentage of conglomerate beds proportionally increased in the upper part of the formation. For the purposes of this theoretical study, that untested assumption has been retained.

The main structural features in the area are the eastward-striking Palmer fault, several faults of smaller displacement, and folds. The Palmer fault separates the Palmer area from the main portion of the Marquette synclinorium. The Palmer area occupies the south limb of the synclinorium.

\subsubsection{Shape and Thorium Content}

The shape, or geometry, of the Goodrich Quartzite has been taken from the geologic map produced by Gair (1975) and must be considered to be approximate only, as sufficient drilling has not been done to confirm the precise locations of several of the boundaries.

The grade, or thorium content, has been evaluated by Gair (1975, pp. 144-146), and is based on a curve he developed relating the thorium content of samples from the Goodrich (measured by gamma ray spectrometer) and the radioactivity (in microengens per hour) observed at the sample sites. The results of his estimates are tabulated on Plate 7 of his paper, in which 
the Goodrich is divided into three areas: 1) Central (which is divided into the upper and lower), 2) Isabella Syncline, and 3) Old Volunteer Mine. Examination of the thorium grades estimated for these areas quickly shows that the upper part of the Central Area is the portion of the Goodrich that contains the highest grade. Thus, the Central Area was chosen as the "conceptual orebody" for this study. In estimating the grade and acertaining the shape of this portion of the Goodrich, Gair leans heavily on work done by Vickers (1956).

We are uncertain as to whether Gair uses thorium assays taken from the core examined by Vickers, or whether he uses the radiometric logs Vickers obtained and published when be probed the holes with a gieger counter. In any event, the grade of 1.06 pounds of thorium per ton was used as the grade basis of the upper portion of the central area in this study. Monazite was assumed to be evenly distributed throughout this part of the deposit for the purposes of mine and concentrator planning. It must be noted that, in fact, this is not the case, as the conglomeratic portions of the upper Central Goodrich Quartzite contain higher radiometric values (hence presumably more monazite) than the quartzite portions. Recognizing this weakness, but also noting that the quartzite portions contain enough radioactivity to make them at least low-grade ore (if Gair's correlation is correct), it is possible that the entire upper portion of the Central Area could be high enough to cover milling costs. Hence, this simplifying assumption is considered reasonable, given the very limited data available.

Vickers had two assays made to establish the thoria $\left(\mathrm{ThO}_{2}\right.$ ) content of the monazite found in the Goodrich. These suggest that the thoria content of this mineral is 8.2 percent 
(also see Overstreet, 1967, p. 167). Accepting the 1.06 pounds Th per ton figure estimated by Gair (for the upper part of the Central Area), the following assumptions were drawn and used in this study: 1) The upper Central Area of the Goodrich Quartzite contains 1.06 pounds per ton of thorium (Th) which is equivalent to 1.21 pounds of thoria $\left(\mathrm{ThO}_{2}\right)$; and 2 ) As the thoria is 8.2 percent of the monazite, the average monazite content inust be 14.7 pounds per ton.

3.2.3 Upper Part of the Central Area

\subsubsection{Mining Geology and Pit Design}

As discussed above, the upper part of the Central Area of the Goodrich Quartzite was selected for conceptual mine purposes. Its shape is based on the "Bedrock Geologic Map and Sections of the Palmer Quadrangle, Marquette County, Michigan," Plate 1 of Gair's 1975 report, and the grade is based on Gair's evaluation of Vicker's work done in 1956.

In order to obtain an appreciation of the total tonnages involved (hence, the potential production rates) and the final shape of an open pit, the following map work was undertaken. Based on the cross sections, the areal extent of the Goodrich Central Area, and the structure interpreted by Gair, a contour map was constructed at a scale of 1 inch equals 2,000 feet, with a contour interval of 50 feet. The contour map (Figure 2) represents the shape of the conceptual orebody. This conceptual orebody has an assumed average grade of 1.06 pounds of Thorium per ton, which is contained in 14.7 pounds of monazite per ton. 


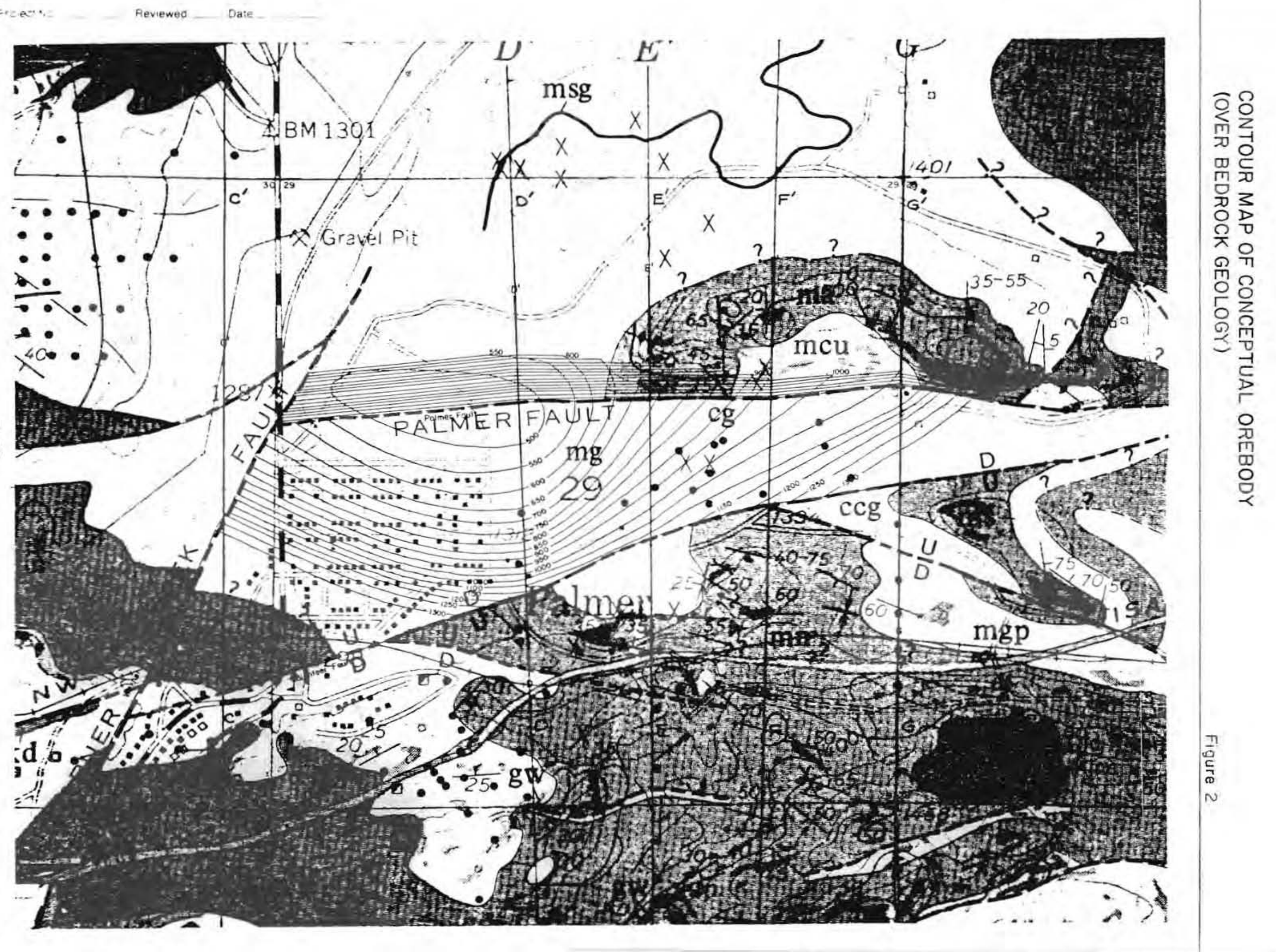


Three pits were designed to remove increasingly larger portions of this assumed orebody. The first has a western edge just to the east of the town of Palmer, avoiding the need to purchase and remove that town. Except for the overlying till, which is assumed to be uniformly 30 feet thick over all of the pits, the pit envelops only ore shown on the contour map of the orebody discussed above.

The second pit has as its boundaries the total areal extent of the upper Central Goodrich, thus, it covers most of the town of Palmer.

The third pit is the same as the second, with the exception of the north wall, which intersects the upper Goodrich halfway between its bedrock surface and its contact with lower Goodrich along the Palmer fault. This permits the excavation of a considerably larger amount of the upper Central Area "orebody" but, of course, also includes more waste rock. After discussing these options with Battelle Northwest, it was decided to use this as the basis for the costing exercise.

The various pits are shown as Figures 3,4 and 5 . Figure 6 shows the bedrock geology and cross sections immediately around the Central Area of the Goodrich Quartzite. All of the pits have 45 degree walls, a reasonable assumption in competent rock such as quartzite. The pits were measured in volume and the specific gravity of all rock was assumed to be 2.7 . The amount of ore and waste contained in each pit is summarized in Table 1. The cross sections showing the various pits projected onto the Upper Goodrich are displayed in Figure 7 . 


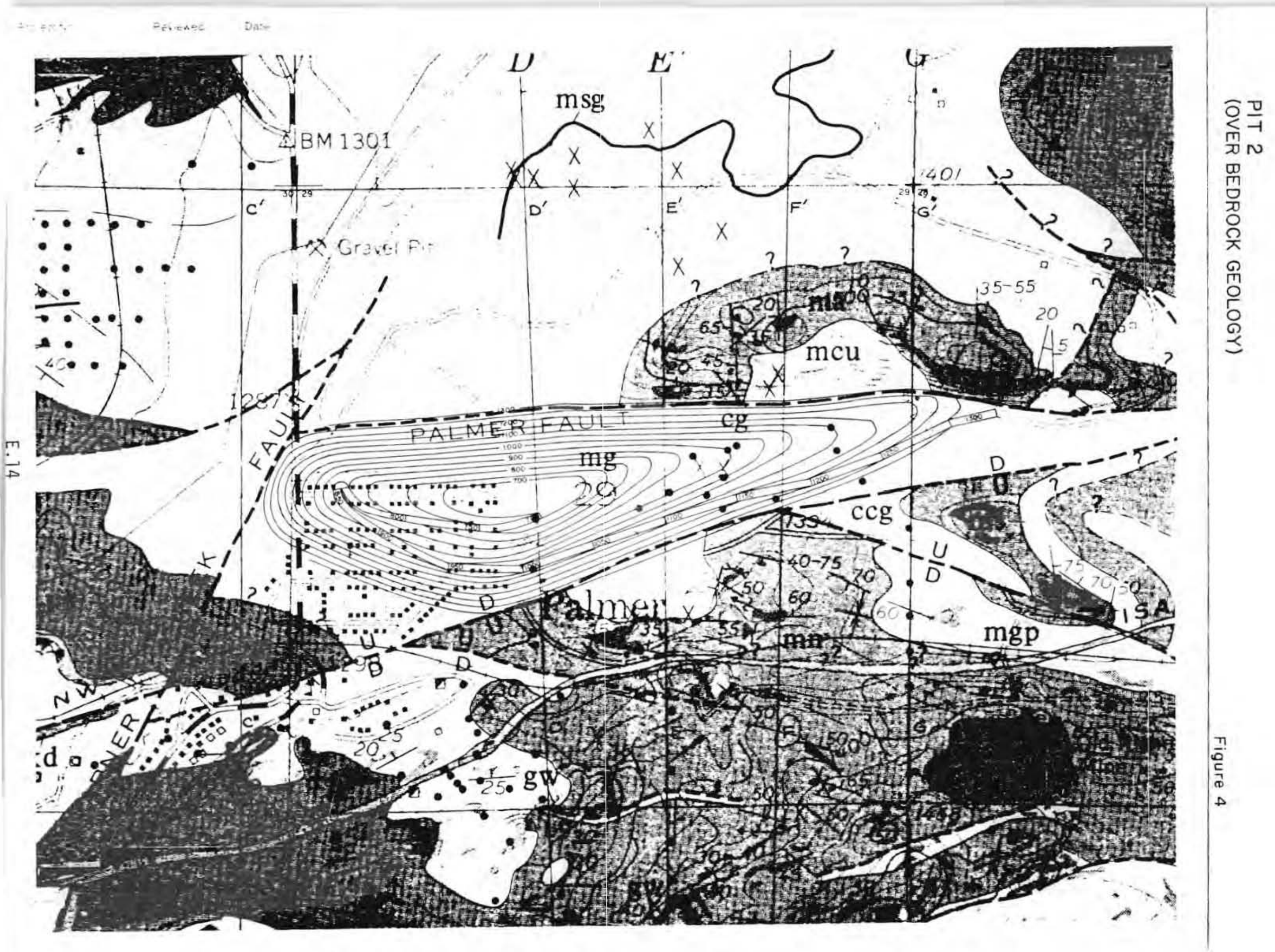


Renewe: Date

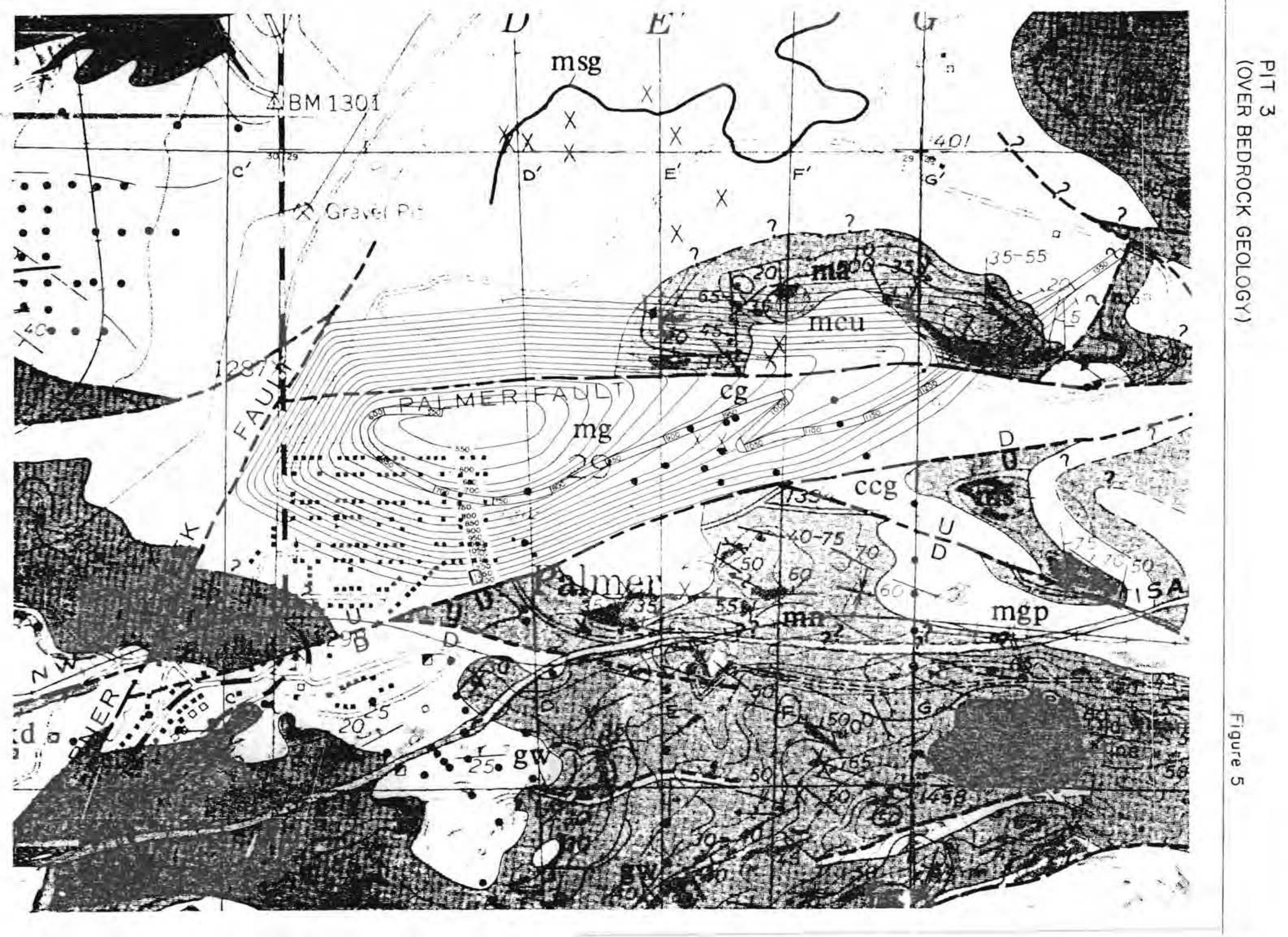



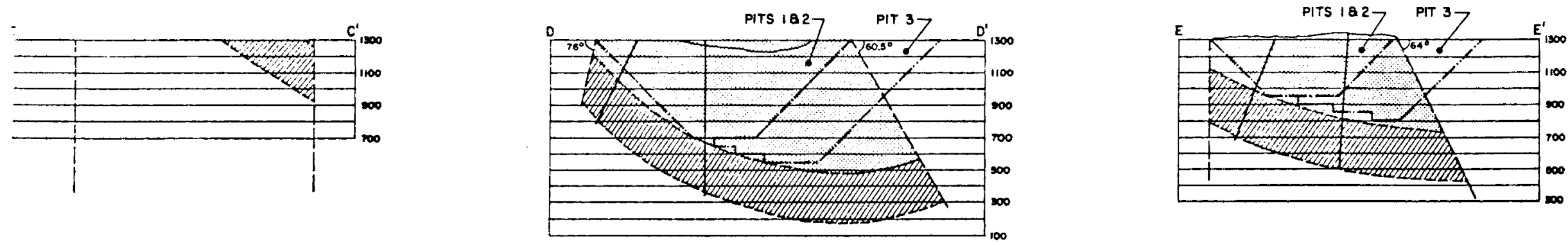

$m$

$\vec{\sigma}$

GODRICH QUARTZITE CENTRAL AREA
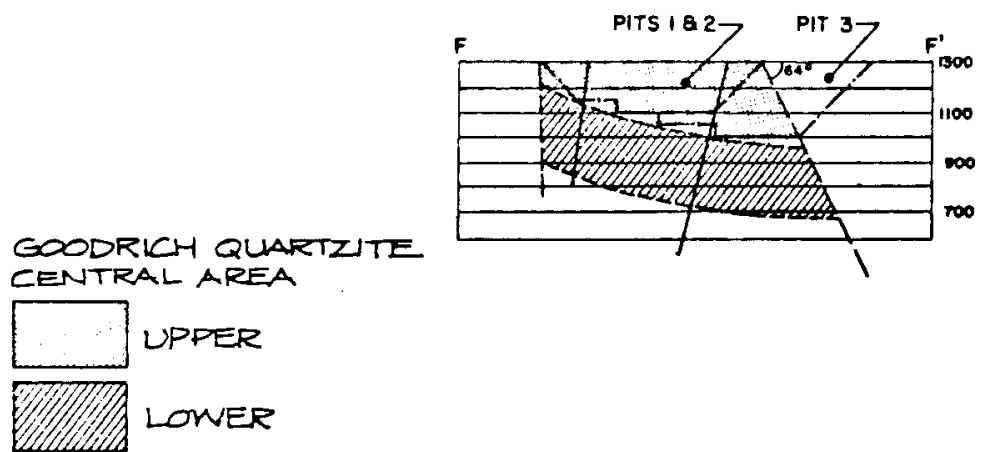

- - FAULTS

DRILLHOLES

(DETAILS ON REFERENCE BELOW)

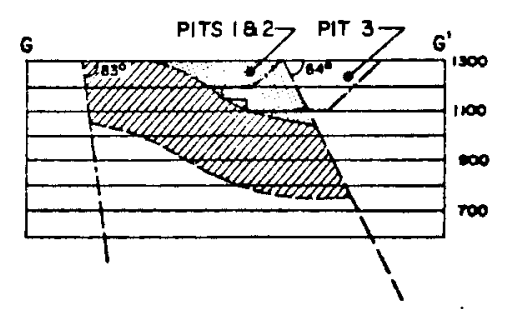

-.-...-PIT OULINES

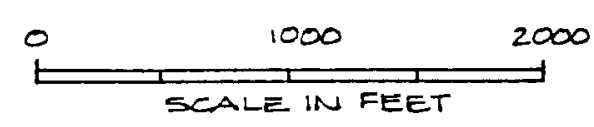

(AfTER GAIR, 1975, PLATE I) 
TABLE 1

ORE \& WASTE IN PITS 1,2 and 3

\begin{tabular}{|c|c|c|c|}
\hline PIT & ORE (TONS) & WASTE (TONS) & SR* \\
\hline 1 & $49,000,000$ & $8,300,000$ & 0.17 \\
\hline 2 & $111,000,000$ & $16,000,000$ & 0.14 \\
\hline 3 & $205,000,000$ & $55,000,000$ & 0.27 \\
\hline
\end{tabular}

$\frac{\text { * Tons Ore }}{\text { Tons Waste }}$ 
The largest pit, which was selected for further study contains 205 million tons of rock containing an assumed 14.7 pounds of monazite per ton, with an assumed 8.2 percent $\mathrm{ThO}_{2}$ content. The pit also contains 55 million tons of waste rock and till. Using a 20-year production life, $10 \mathrm{million}$ tons of ore could be produced each year from the selected pit. In addition, about three million tons per year of waste rock and till would have to be moved.

\subsubsection{Concentrator Recoverability}

To our knowledge, no tests have been made on the Goodrich to determine the overall recoverability of the monazite minerals (the percentage of monazite recovered in the concentrate and an well the percentage of gangue or waste minerals reporting to that concentrate). Vickers (1956) reported that heavier minerals, including monazite, could be separated after crushing and grinding, but did not attempt to quantify the percentage recoverability. Borrowman and Rosenbaum (1962, p.2-3) indicate the successful laboratory separation of monazite from the Deadwood Conglomerate found at Bald Mountain, Wyoming. The overal1 recovery of monazite was 61 percent by weight. Our interpretation of these results is shown in Figure 8.

Assuming that the Goodrich behaves in much the same manner as the Deadwood (an argument can be advanced that they both may have at least similar monazite grain size distributions), then a materials balance would result as indicated on Figure 9.

Lacking other data, the assumption that a 61 percent overal1 recovery through the concentrator was applied to the Goodrich in this study. The concentrator would require the following elements: 


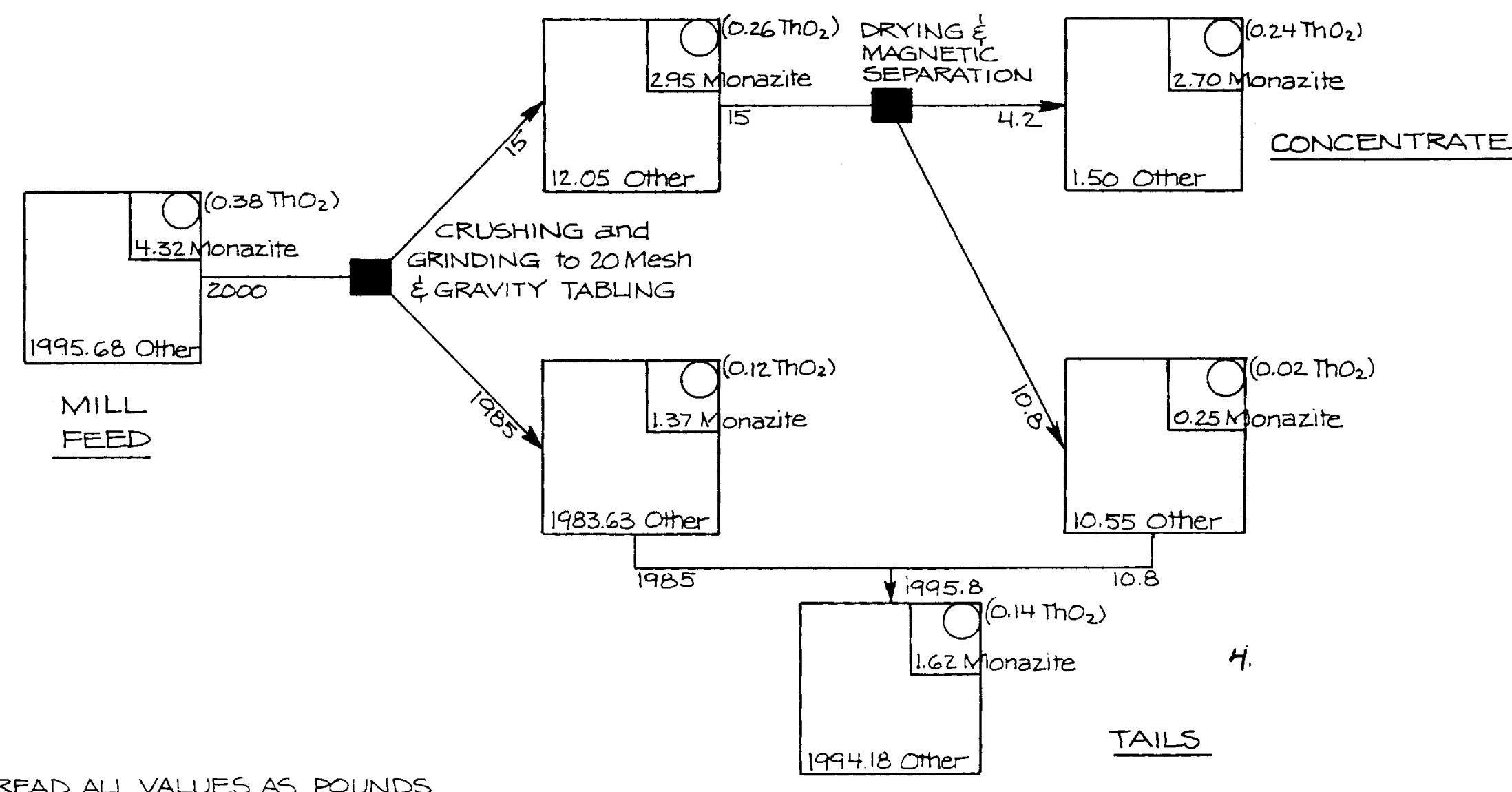




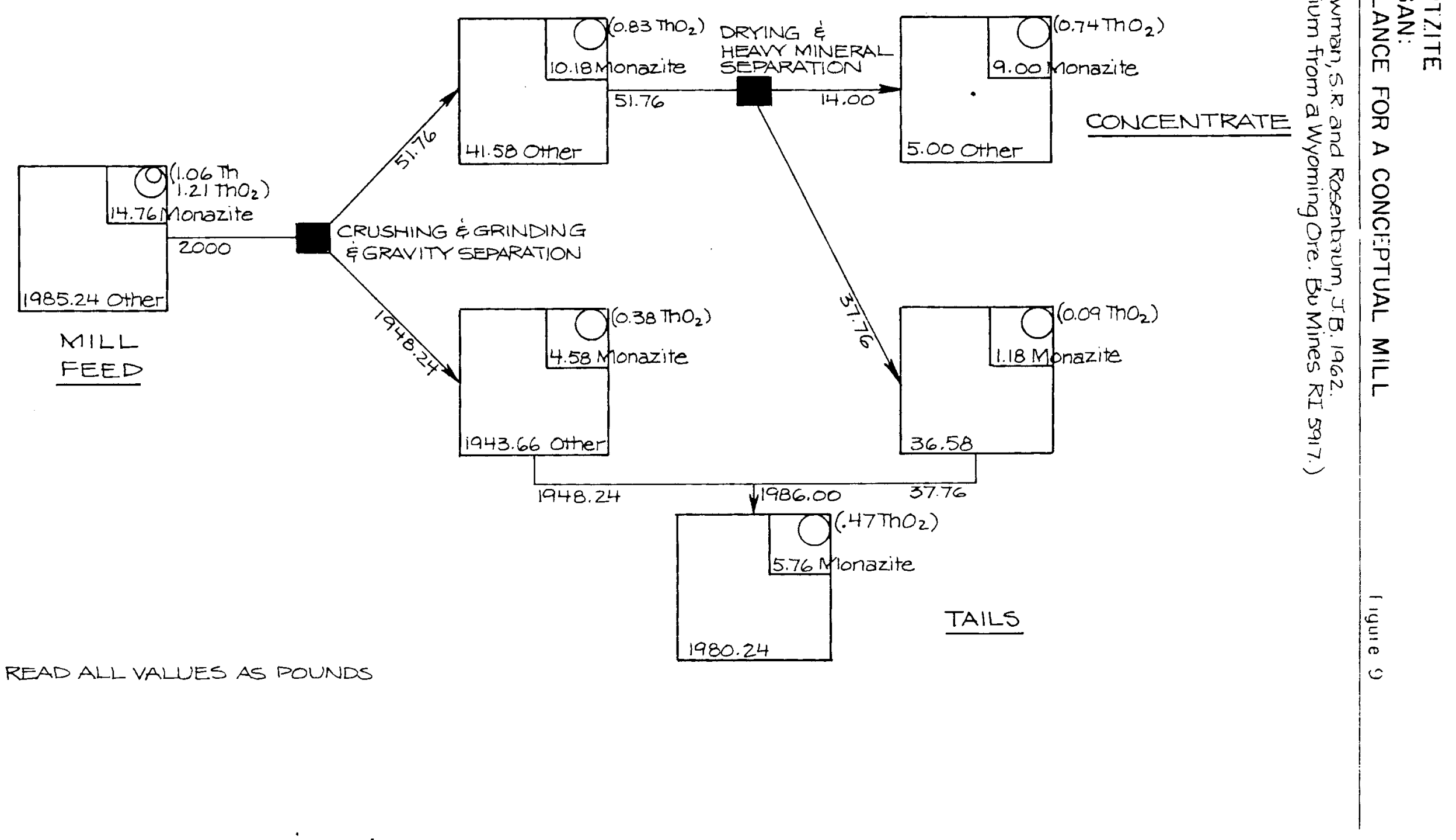


1. A crushing and grinding circuit which would reduce the run of mine ore to optimum size (probably -20 mesh).

2. A gravity section (probably spirals) which separates the heavy minerals from the lighter gangue minerals.

3. A heavy mineral section which would separate the heavy minerals (i.e., rutile, ilmenite, and magnetite) from monazite.

4. A tailings disposal section which would transport and place the mill tailings to the tailings pile. 
4.0 DEVELOPMENT SC'HLUULL:

\subsection{General}

In order to examine and estimate costs for the many and diverse tasks that need to be completed before the mine and mill could successfully be brought onstream, a development schedule was prepared and is attached as Figure 10. The schedule is divided into years, with a zero point designated as the time at which the mill would commence production of monazite concentrate. The sales of this concentrate would presumably produce revenue. For this reason, the years after the zero point are designated "revenue" and the years before "pre-revenue". Eleven pre-revenue years requiring large expenditures of capital are thought to be necessary to bring the mine into production in an order 1y way.

Four different activities or phases have been identified: exploration, pre-mine development, construction, and operations. The purpose and scope of each of these phases is discussed in more detail below and costed in section 5.0 .

\subsection{Exploration Phase}

\section{2 .1 purpose}

The shape and distribution of the monazite, within the Goodrich the thorium content of the monazite, and the physical characteristics of the ore that will determine the recovery of the monazite in a concentrating plant, are not well understood. The assumptions made for the purposes of this study would have to be verified before any further funds could prudently be ventured. The U.S. Geological Survey classifies the Goodrich Quartzite as an identified resource which, in terms of certainty, 
pre-revenue orevenue.

EXPLORATION PHASE LAND AQUISITION

EXPLORATION GEOLOGY

OTHER

PRE-MINE DEVELOPMENT PHASE LAND AQUISITION

MINE GEOLOGY

TECH \&ECON. FEASIBILITY STUDY PERMITS

CONSTRUCTION PHASE MILL CONSTRUCTION CONST. OF MINJE FACILITIES

OPERATIONAL PHASE MILL OPERATIONS MINE OPERATIONS

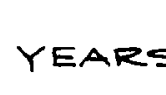

YEARS |

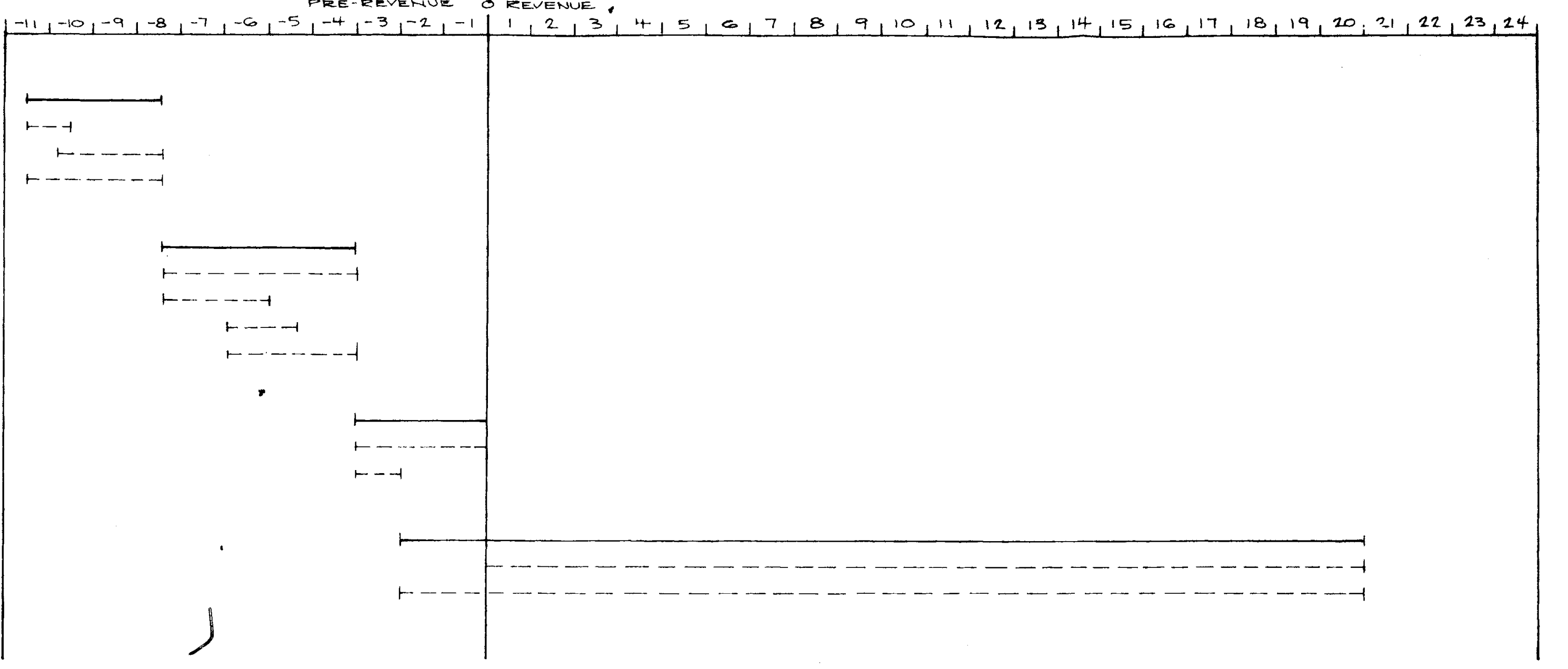


is far from being a possible, much less proven, orebody.

For these reasons, mineral exploration will have to precede al1 the other phases. Assuming these results are favorable, the project could then proceed.

\subsubsection{Details}

This phase has been divided into two important subtasks. The first of these is land acquisition. During this subtask, enough mineral rights with overlying surface rights would be tied up, probably by means of options that could be exercised later, to ensure the success of the operation should exploration results prove favorable. Also required would be landowners' permission to allow access for drilling and other necessary tests during the drilling portions of the exploration phase.

The second subtask, exploration geology, has been further subdivided into two subphases. During the first subphase, several holes (15 are thought to be sufficient) would be cored through the Goodrich. These holes would test the concept of the resource, both from a geometrical and grade/tenor standpoint, and also develop enough physical data on the mineralized zone to enable judgements to be made with some assurance about recoverability of the monazite mineral in a concentrator. At the end of first subphase drilling, the deposit would be interpreted geologically and a prefeasibility study would be done. If this study were favorable, second-subphase drilling would be allowed to continue (having been started before the study was completed). If the prefeasibility study is unfavorable, the whole project, including the land options, could be dropped. 
The second subphase of drilling would require about 85 holes. Assuming that a reliable correlation can be developed between thorium content and amplitude of the radiometric log, only 22 holes would require complete coring. The other 63 could be drilled and logged radiometrically, which would be less expensive than coring.

The 100 holes from subphases one and two would now be reinterpreted and another prefeasibility study made. If the results were favorable, the deposit would enter the pre-mine development phase as a largely proven orebody. Through both drilling phases, enough metallurgical tests (grain size, grindability, and recoverability analyses) would be necessary to assure the recovery of the monazite mineral in a concentrator. Three years is estimated to be required to complete the exploration phase.

\subsection{PRE-MINE DEVELOPMENT PHASE}

\subsubsection{Pur pose}

The purpose of this phase is to: 1) continue the land acquisition program; 2) completely delinate and determine grade and recoverability distributions within the orebody; 3 ) perform a first-order technical and economic feasibility study; and 4) obtain the necessary mining permits to allow construction, mining and mill operations to proceed.

\section{3 .2 Details}

Land acquisition would continue, with surface and mineral rights being purchased or leased as necessary. The mine geology subtask would consist of sinking another 200 holes to completely delineate the orebody and determine the grade distribution of the monazite mineral and its recoverability by milling. In 
addition, a large bulk sampling program would be required to provide ore to a pilot mill. The purpose of the pilot mill is to provide detailed mill design parameters. This program would obtain ore from underground workings by sinking a shaft in a "representive" spot in the orebody, and by driving drifts at various vertical intervals down the shaft.

As certain portions of this data become available, feasibility studies would commence. These studies would have as an overall purpose the mine design and costs, the mill design and costs, and an overall project cost determination, as well as a financial analysis.

Assuming favorable results, necessary permits would be sought. These would probably require environmental impact studies, followed by submission of plans, hearings and, hopefully, the issuance of permits.

Four and one-half years are thought to be necessary to complete the pre-mine development phase in an orderly fashion.

\subsection{Construction Phase}

\subsubsection{Purpose}

During this period, the stationary plant required for the project will be constructed. This will consist of a concentrator, mine service buildings, power lines, access roads, and all other items that are required to make production posisible. 
4.4.2 Details

In this study, all construction, including final design, procurement and construction management, will be assumed to be handled by an engineering construction firm. Their services will not extend to pre-mine stripping, a point which will be covered below.

The construction phase has been assumed to require three years to complete.

\subsection{Operational Phase}

\section{5 .1 Purpose}

The purpose of mine and mill operations is to perform the operations necessary to produce a salable concentrate throughout the life of the project.

\subsubsection{Details}

\subsubsection{Mine Operations}

An excavation schedule has been formulated (Table 2) which indicates the annual tonanges of ore and waste that are estimated to be required to maintain a constant mill feed to the concentrator.

Normally, such a schedule is based on a detailed mining excavation plan which shows, bench by bench, pit expansion by pit expansion, the flow of ore and waste throughout the life of the mine. Such a detailed study is not warranted, and would normally not be made until the feasibility stage of the pre-mine development phase. The schedule presented herein is simply 
TABLE 2

ANNUAL EXCAVATION SCHEDULE - PALMER THORIUM MINE

\begin{tabular}{|c|c|c|c|}
\hline YEAR & WASTE & $\underline{\mathrm{ORE}}$ & ORE \& WASTE \\
\hline & (Millions of & Tons) & \\
\hline-2 & 3 & & 3 \\
\hline-1 & 3 & & 3 \\
\hline 1 & 3 & 6 & 9 \\
\hline 2 & 3 & 8 & 11 \\
\hline 3 & 3 & 10 & 13 \\
\hline 4 & 3 & 10 & 13 \\
\hline 5 & 3 & 10 & 13 \\
\hline 6 & 3 & 10 & 13 \\
\hline 7 & 3 & 10 & 13 \\
\hline 8 & 3 & 10 & 13 \\
\hline 9 & 3 & 10 & 13 \\
\hline 10 & 3 & 10 & 13 \\
\hline 11 & 3 & 10 & 13 \\
\hline 12 & 3 & 10 & 13 \\
\hline 13 & 3 & 10 & 13 \\
\hline 14 & 3 & 10 & 13 \\
\hline 15 & 3 & 10 & 13 \\
\hline 16 & 3 & 10 & 13 \\
\hline 17 & 1 & 10 & 11 \\
\hline 18 & & 10 & 10 \\
\hline 19 & & 10 & 10 \\
\hline 20 & & 10 & 10 \\
\hline 21 & & 10 & 10 \\
\hline 22 & + & 1 & 1 \\
\hline DTALS & 55 & 205 & 260 \\
\hline
\end{tabular}


an estimate based on our present appreciation of the geometiry of the orebody and the most probable results of a detailed study.

This schedule calis for two years of pre-revenue stripping at a three million ton-per-year (tpy) rate. This is followed by two years of increasing ore deliveries (plus stripping), after which the total movement of ore and waste would stabilize at $13 \times 106$ tpy, consisting of $10 \times 10^{6}$ (tpy) of ore and $3 \times 10^{6}$ tpy of waste.

This is assumed to be done on a three shifts per day, five days per week basis, with an allowance of 10 days per year for holidays and 10 days per year lost due to weather and other work stoppages. The schedule, therefore, calls for a 240-day (at three shifts per day) working year for mine operation or 720 shifts per year.

When production has reached the 13 million tpy level, an average daily movement of 54,167 tons will be required. Of this, 41,667 tpd will be ore and 12,500 tpd will be waste on average. Mine equipment and shops will be sized around these parameters.

\subsubsection{Mil1 Operations}

The mill will be designed to operate with three shifts around the clock all year long. Practically, however, an estinated 35 days will be lost to holidays, other work stoppages, and maintenance. In this study, a 330-day working year was assumed. 
$\Lambda$ discussed in section 4.5 .2 .1 on mine operations, the average daily deliveries to the primary crusher will be 41,667 tpd. On peak days, when all equipment is operating and mining ore, this will be much larger. The primary crusher will have to be manned 240 days a year, and a storage facility for primary crushed ore will have to be provided. This facility should hold about a five-day milling supply, or about 150,000 tons.

Downstream from the storage facility at the secondary crushing and ore-grinding stations, the mill would be designed to handle 10 million tpy, or $30,303 \mathrm{tpd}$. These parameters have been used to size the mill. 


\subsection{COS'T SUMMARY}

The following tabulation (Table 3 ) summarizes the costs estimated to place this project onstream and to produce a concentrate throughout the operating life of the project. The annual production of concentrate is also indicated.

These costs are developed in more detail in Appendix A. 
APPENDIX A 
CAPITAL COSTS (\$000 MISSING)

EXPLORATION PHASE

PRE-MINE DEVELOPMENT PHASE

CONSTRUCTION PHASE

OPERATIONAL PHASE

PRE-RE-VENUE_ STRIPPING

REPLACEMENT OF MILI EOLIPMENT

REPLACEMENT OR MILL EQLIPMENT

TOTAL CAPITAL

DEPRECIATION OF CAPITAL (\$ 000 MISSING)

DRE-REVENUE EXDENDITUEES (20yrl. fe -o m.mine equip.)

MILL EQUIDMENT REPLACEMENT

MINE EQUIPMENT

TOTAL OEPRECIATION

OPERATING COSTS (\#00O MISSING)
MILL
(TABLE A-L)
LABOR
$M \xi S$
MINE
(TABLE A-5)
LABOE
$M \& S$

TOTAL OPERATING

CONCENTRATE PRODUCTION (TONS OOO MISSING)

TONS OF CONCENTRATE, ')

MINE PRODUCTION (TONS OOO MISSING)

WASTE

ORE

TOTAL

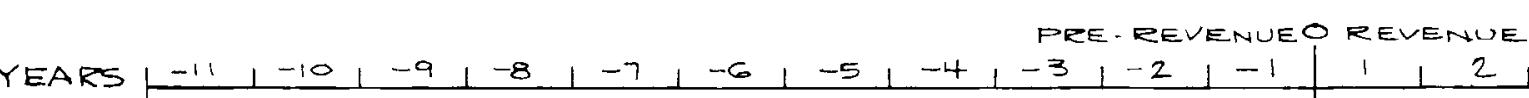

\section{$\begin{array}{lllll}\text { (TABLE A-1) } & 320 & 1,289 & 1,152 & 2,7\end{array}$}

(TABLE A-2)

(TABLE A-3)

$\begin{array}{lllll}3,128 & 8,457 & 8,63 & 8,906 & 504+2\end{array}$

$19,720 \quad 55,000 \quad 85,000$

15,8117906

$320 \quad, 289 \quad 0,52 \quad 3,345 \quad 8,457 \quad 8,165 \quad 8,906 \quad 5,0+2 \quad 35,531 \quad 65,994 \quad 88,080$
7,000

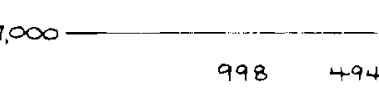

$998 \quad 494$

$9484 \quad 4737$

$998 \quad 494$

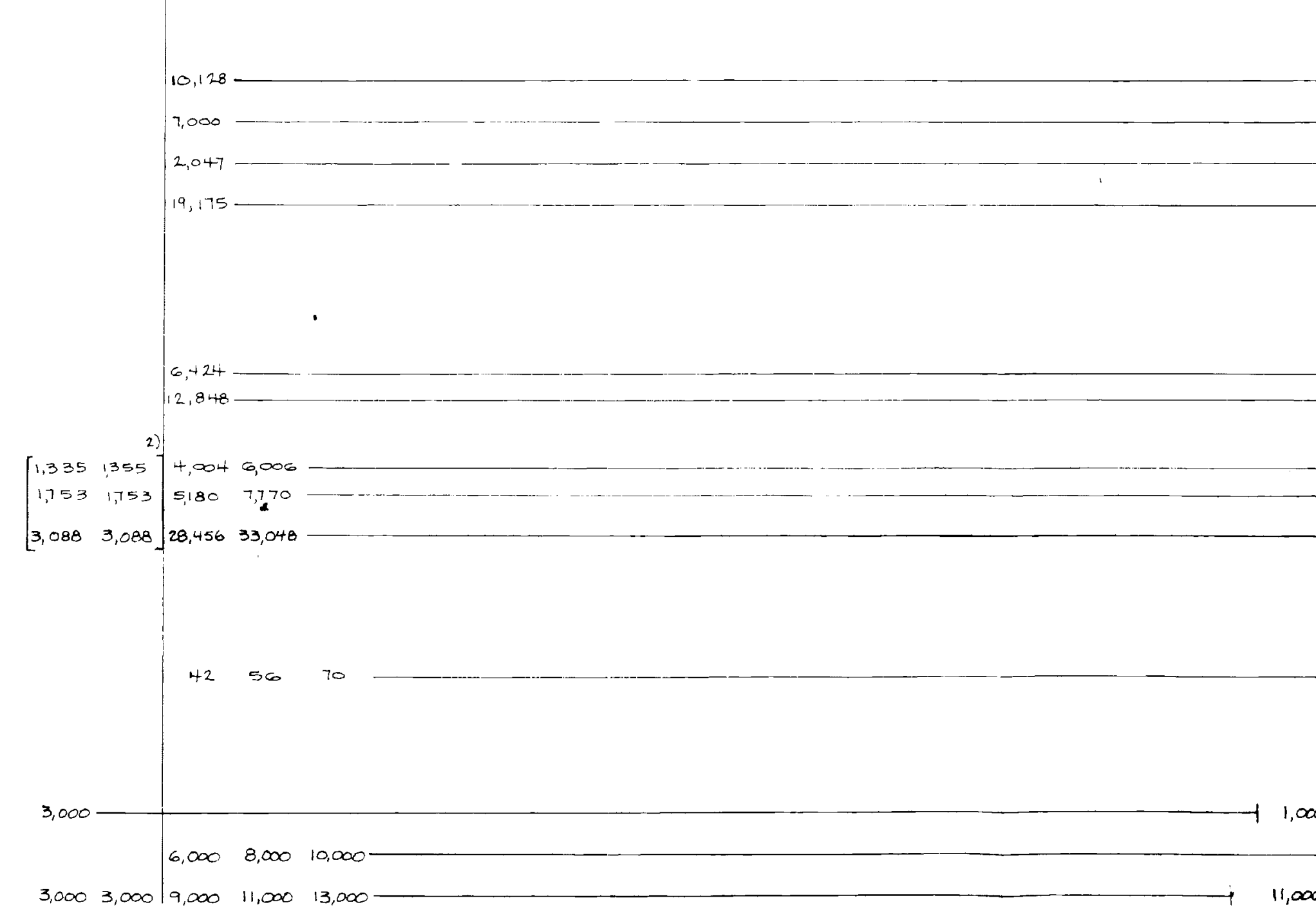

NOTES: 1.) (a) Each ton of concentrate requires 142.9 tons of mill feed (b) Each ton of concentrate contains 1286 pxunds of monazite. (c) Monazite is $8.2 \%$ by weight $\mathrm{ThO}_{2}$.

3.) Last two years on tted 


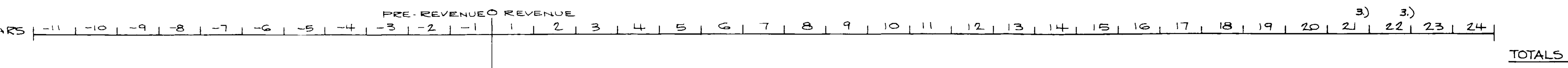

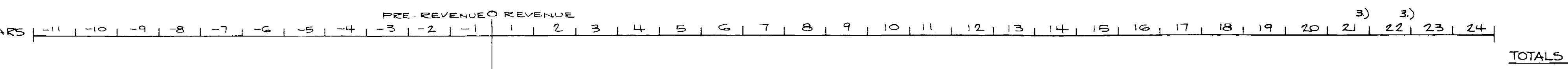

$320 \quad 1,289 \quad 1,152 \quad 217$

$\begin{array}{lllll}3,28 & 8,457 & 8,65 & 8,906 & 504+2\end{array}$

$19,720 \quad 55,00085,000$

$3,088 \quad 3,088$

$5,8117,906$
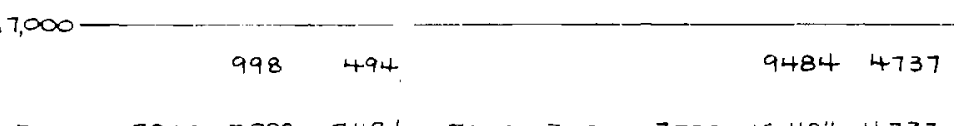

$998 \quad 494$

(NO REPLACMTI)

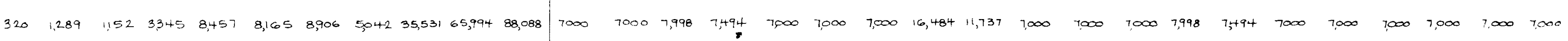

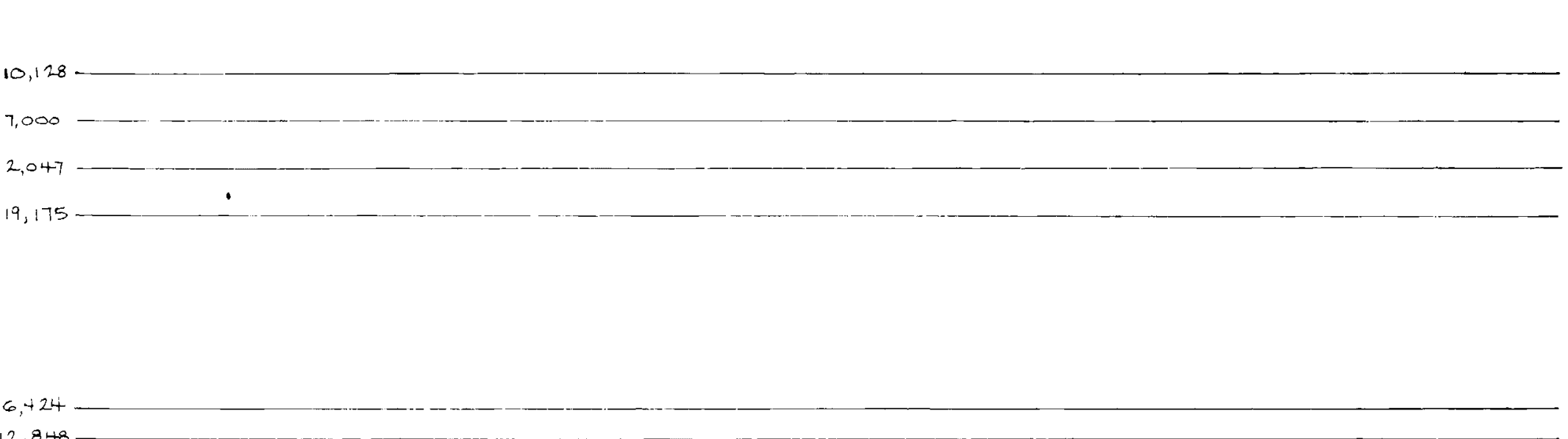

6,424

2,978

33,698

159,720

6,76

140,000

40.922

383,500

202,560

140,000

40,940

383,500

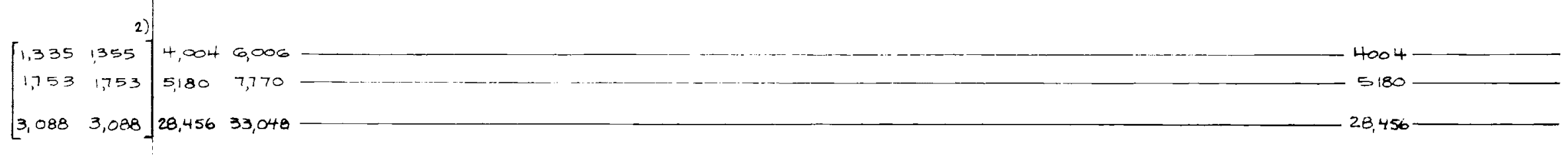

$128,+80$

256,960

112,112

145,040

642,592

3,000

$6,000 \quad 8,000 \quad 10,000$

1,000

$3,000 \quad 3,000 \quad 9,000 \quad 11,000 \quad 13,000$

$11,000 \quad 10,000 \quad 10,00010,000$

\section{1,358 \\ 194,000 \\ 249,000}

of concentrate contains 1286 peunds of monazite.

zite is $8.2 \%$ by weight $\mathrm{ThO}_{2}$

Wo years or tted 


\section{REFERLNCES}

Borrowman, S.R., and Rosenbaum, J.B., 1962, Recovery of thorium from a Wyoming ore: U.S. Bur. Mines Rept. Inv. 5917, 8 p.

Gair, J.E., 1975, Bedrock geology and ore deposits of the Palmer quadrangle, Marquette County, Michigan: U.S. Geological Survey, Professional Paper 769.

National Oceanic and Atmospheric Administration, Climatological Data: U.S. Environmental Data Service, 1975, Michigan, V. 90 , Nos. 1-13.

Overstreet, W.C., 1967, Michigan, In The Geologic Occurrence of Monazite: U.S. Geol. Surv. Prof., Paper 530, p. 166-167.

U.S. Department of Commerce, Weather Bureau 1963. Local Climatological Data with Comparative Data, Marquette, Michigan.

Vickers, R.C., 1956, Geology and monazite content of the Goodrich Quartzite, Palmer area, Marquette County, Michigan, In Contributions to the geology of uranium: U.S. Geological Survey, Bulletin 1030-F, pp. 171-185. 

ACTIVITY हุ COST ITEMS

EXPLORATION PHASE

LAND ACQUISITION

INITIAL OPTIONS OR LEASE

EXPLORATION GEOLOGY

INITIAL DRILLING E MILLING TESTS

MTER-FEATIBILITY STUDIES

OTHER

ANNUAL TOTALS
YEARS

$-11$

$-10$

$-9$
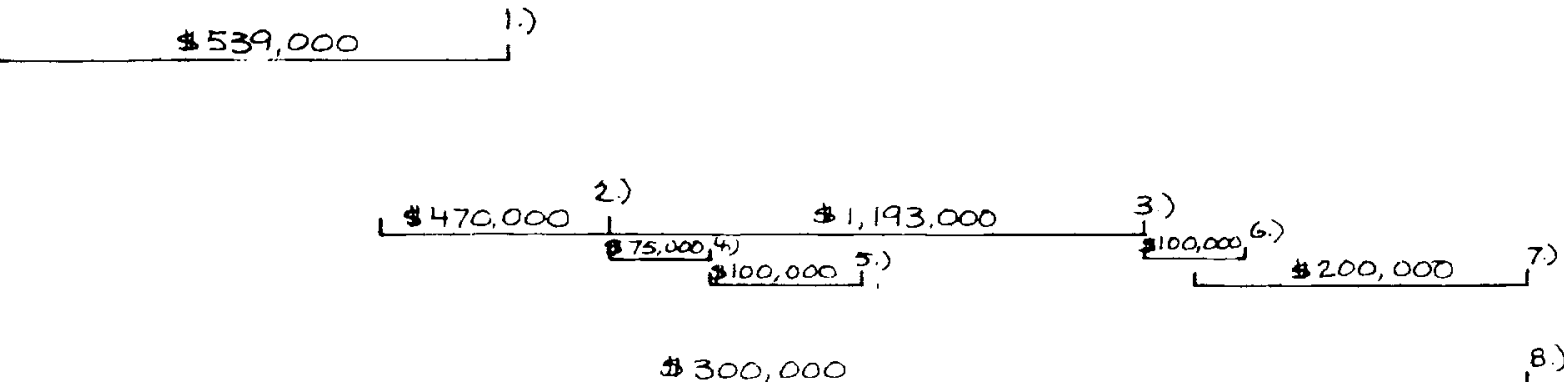

300,000
COST ESTIMATE:

1.)INITIAL OPTIONS OR LEASE

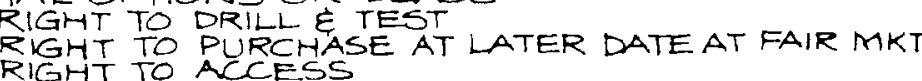
HIO AC OF WHICH I280 ARE POTENTIALLY
MINERAL BEARING, ALO TOWN OF PALMER PALMER $=\begin{aligned} & 3520 \text { AC } \$ 50 / \text { AC } \$ 200 / A C \\ & 646,000\end{aligned}$

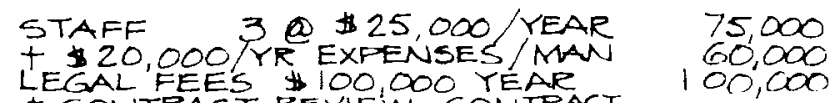

2)INITIAL DRILLING E MILLING TESTS:

$$
\begin{aligned}
& \text { 15 HOLES CORED TOP TO BOTTOM (700 FT) } \\
& \text { WIT GEOP LOGGINGT TOFT CONTRACT } \$ 210,000 \\
& \text { ASSAMNG WORK SAY } 3500 \text { SAMPLES } 88,000 \\
& 3 \text { GEROGISTS@25,000/YR. } 68,000 \\
& \text { PLUS ZOR,000/YR/MAN EXPENSES } 54,000 \\
& \text { PRELIMINARY MILLING TESTS } \quad 50,000
\end{aligned}
$$

3) INITIAL DRILLING $\frac{1}{4}$ MILLING TESTS BOTOM S TOO 22 CORED WITH TOP TO

$$
\$ 25 / \text { ASSAY }
$$

$\$ 319,500$

\$308,000
$\Delta_{\# 1,152,143}$ $\$ 216,66$ $\triangle=$ DROPOUT POINTS TOTAL $\$ 2,977,000$

2) 63 HOLES GEOP LOTS ONLY 309,000

109,000

MILLTESTS SAY 100,000

3 GEOLOGISTS@, SEE ABNVE 157,000

4) INTERPRETATION OF PHASE ONE

CONSULTANT FEE BASED ON RECENT EXPERIENCE \$75,000
DRILLING

5.) PRE CEEASIBILITY STUDIES PHASE ONENATE

100,000

6) INTERPRETATION OF PHASE TWO

CONSULTANT FEE-RECENT EXPERIENCE 100,000

7) PRE - FEASIBILITY STUDIES PHASE TWONGE
CONSULTANTTEE-RECENTEXPRIENCE

8) TTHER EXPLORATION MANAGEMENT, G\& A, ETC

$$
\$ 100,000 / Y R \text { 300,000 }
$$

TOTAL \$2,977,000

$\triangle$ DROPOUT POINTS 



\section{ACTIVITY \& COST ITEMS}

YEARS $-8$

PRE-MINE DEVELOPMENT PHASE LAND AQUISITION

$$
\text { LAND DURGHASE or lease }
$$

MINE GEOLOGY

OREBODY DELINEATION \& GRADE

DISTRIEUTION DETERMINATION

BULK SAMPLING FOR MILL DESIGN

TECH. \& ECONOMIC FEASIBILITY STUDIE S MINE DESKGN \& MINING COSTS

MILL DESIGN \& MILLING COSTS

PROJECT COSTS

PERMITS

ENVIRONMENTAL IMPACT STUDIES

SUBMISSION OF PLANS EHEARINGS PERMITS

$1 \quad 1) \quad \$ 11,750,000 \quad 180,000 \quad 123$

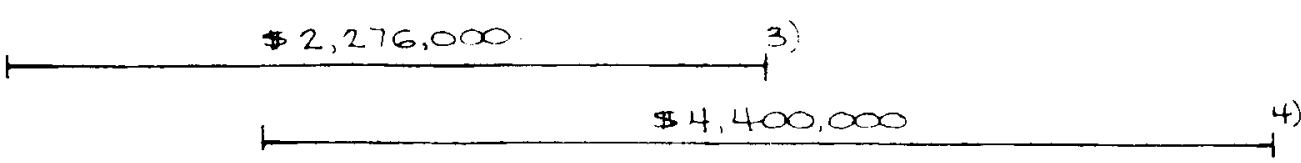

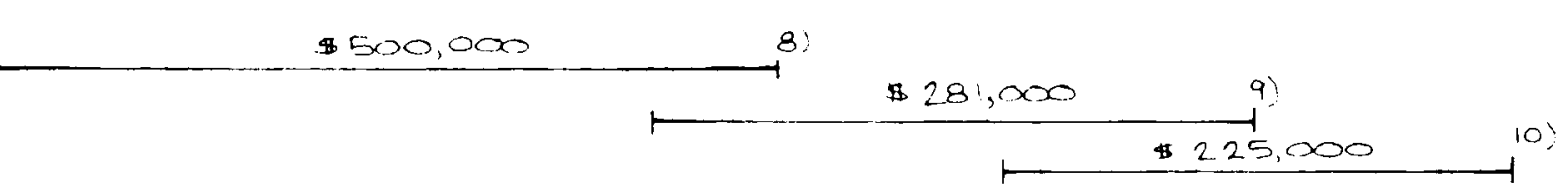


COST ESTIMATES:

1. LAND PuRchase or lease - phase I

d) 3520 AC. D $875 / A C$

$\$ 3,080,000$

SAY PUREMASED OUTRKGT

AT THIS TIME

b) TOWN OF PALMER - 250 HOMES (GHOAC) DO $\$ 60000$ AVERAGE PER DME $=\$ 15,000,000$

I/3 PAIDINTO ESCROW ACCOUNT NOW 2/3 FAID IN YEAR - 4

C) ALSO BUDGET \$ 700,000/YEAR FOR RLHT OF WAYS - LEGAL FEES AMD MANTAINENCE OF SMALL LAND-

MAN STAFF OTHER LAND PURCHASES

ERELOCATION EXPENSES

2. LAND PURCHASE oR LEASE-PHASE II a) FINAL PURCHASE OF PAMMER

b) BUDGET \$7ro,000 (see c) above)

10,000,000

$\$ 1,750,000$

3. OREBODY DELINEATION E GRADE OISTRIBUTION DETERMINATION

a) 200 DRIU HOLES 700 'DEEP $25 \%$ COEED F SOSAYED D 2 ' (5O holes) $75 \%$ GEOPHYSICAL LOOS ONLY (15O holes)

CONTEACT \$20/FT. CORE

* 25/FT ASSAT

\# 7/FT. PLUG DRLLED

3 GEONOGISTS D $\$ 25,000$ YR PLUS $\$ 20,000$ EXPENSES

MILLING INFO FROM CORES

PHOTOMIC.ROGRADHS SAY

4 BULK SAMPLING FOR MILL DESIGN

a) SINK S'X10' SHAFT $600^{\prime} D$

- 1,000/FT. -1/2 YR. Contreact

b) Supply 50 TONS/ Dar for $11 / 2$ YRes. LABOR IO MEN Q \$25P0O/YR, PWS \$20,0OC/YR. EXPDENSES

c) Mis à COST OF ABOVE LABBOR

d) FURCIMASE 4 OPERAT KON OF FILOT MILL

SOTPO D 20,DOO/DAILY TON

e OPERATE IOMEN (see atoove)

f) MES

9) OPERATING perimits say

675,00

\$ 1,000,000 675,000 675,000
5. MINE DESIGN E MINING COSTS

9) INTERDRET ORE DOOY, MINE DESIGN, COST OPERATION. REQS. 3 GEOL/ENGR., 2 DRAFTSMEN, ISEC. EQUIVALENT CONTRACT PRESENTLY BEING DONE GOLDER AsSOC. Expenses \& FEES

6. MILL DESIGN EMILLING COSTS a) FLOW SHEET, EQUIPMENT SELECTION COSTS (to feasibility standards) TO BE DONE BY ENGR CONST FIEM. ESTIMATE COST 25 MAN YEAES D $2.5 \times$ PAYROLL COST: $25 \times 30000 \times 1.25 \times 2.5$ EXPENSES $\$ 30,000 \times 1.25 \times 2$

$\$ 2,344,000$ EXPENSES D $25 \%$ OF LABOR

7. PROJECT DESIGN E COSTS

a) INERASTRUCTURE DESIGN E⿱ COSTS,

ECONOMIC ANALYSIS, ETC.

SAT 10 MAN YEARS D 2.5 PAYROLL COSTS

OX $\$ 30,000 \times 1.25 \times 2.5$

\$ 938,000

EXPENSES DO $50 \%$ OF LABOR

\begin{tabular}{l}
$\$ 38,000$ \\
\hline$\quad 469,000$
\end{tabular}

\$1 1,407,000

8.ENVIRONMENTAL IMPACT STUDIES a) COLLECTION OF BASE DATA \& REPORT BASED ON MINING \& MILLING PLANS, RECENT EQUIVANENT STUOY

COST APPROXIMATELY

9. SUBMISSION OF PLANS \& HEARINGS a) WILL REQUIRE A STAFF OF 5 MEN

1.25 YeARS OR 6.25 MAN YEARS D

\$45,000 MAN YEAR DaYroLL I

OTHER EXPENSES

10. OBTAINING PERMITS

d) SAME STAFF LEVEL AS 9)(above) FOR IO YEAR

$\$ 225,000$ $\$-\frac{100,000}{4,400, \infty}$ 

ACTIVITY \& COST ITEMS:

CONSTRUCTION PHASE

MILL CONSTRUCTION

FINAL DESIGN, PROCUREMENT

\& CONSTRUCTION MANAGEMENT

CONSTRUCTION OF MILL AND

OTHER FACILITIES

CONSTRUCTION OF MINE FACILITIES SHOP \& OFFICE \& $\dot{E}$ PIT POWER

DISTRIBUTION SYSTEM

ACCESS ROADS - PIT

ANNUAL TOTALS

1)COMPLETE ENGR SERVICES DURING CONSTRUCTION PHASE FINAL DESIGN PROCUREMENT AND CONSTRUCTION MANAGEMENT AT $10 \%$ OF INSTALLED COST OF ITEMS BEING CONSTRLCTED $\$ 145.2 \times 10^{6} \times 0.10$

2) CONSTRUCTION OF MILL

a) PRIMARY,CRUSHER (REF, SUNNYSIDE
e $\$ 296$ /DALY TON (RE, STUDY)
$\times 41667$

b.) STORAGE 150,000 WITH RECLAIM

STACKING BELT-1,000,000
RECLAIM HOPPERS- 500,000 OTHER (SITE, SONTROLS,ETC) 400,000 $1,900,000$

C.) SECONDARY CRUSHERS E GRINDING GEF, NACAZARI) X/ DOSOY TON (REF. NACAZARI) $\times 30303$

\begin{tabular}{|c|c|c|c|}
\hline YEARS & -3 & -2 & $\begin{array}{l}\text { PRE-REVEN } \\
-1\end{array}$ \\
\hline & $\$ 4,520,000$ & $\$ 5,000,000$ & $\$ 5,000,000$ \\
\hline & $\$ 10,000,000$ & $\$ 50,000,000$ & $\$ 80,000,000$ \\
\hline
\end{tabular}

L $\$ 5,200,000$

$\# 19,720,000$ $\$ 55,000,000$ $\$ 85,000,000$

3)CONSTRUCTION OF MINE FACILITIES SHOP $\times$ OFFICE $100^{\prime} \times 300^{\prime}$

$2,100,000$

DLUS SHOP $\xi$ WAREHOUSE $\xi$

OFFICE EQUIPMENT SAY
(REF. PFB. SUNNYSIDE)

$\$ 14,520,000$

$\frac{1,000,000}{3,100,000}$

PIT POWER $\frac{1,000,00}{3,100,000}$

@ 400,000 (REF.PFB SUNNYSIDE) 400,000

ROADS AT SAY (REF. PFB S'SIDE)

$12,350,000$

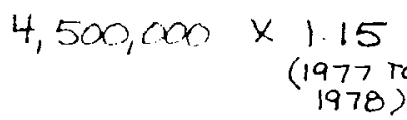

$\$ 5,200,000$

TOTAL $\$ 159,720,000$

d.) GRAVITY E MAGNETIC SYSTEM (REF. PFB \$S SUNNYSIDE)
$2000 \times 30300$

e) TAILINGS DISPOSAL \$100/DAILY TON (REF. PFB, SUNNYSIDE)

$3,030,000$

$\$ 120,310,000 \times 1.15$ INFLATION 1977 TO 1978 USE $\underline{140,000,000}=4620 /$ DAILY TON $(30,000$ TPD) 

OPERATIONAL PHASE: ESTIMATED ANNUAL COSTS-MILL OPERATIONS (30,000 TPD - 10,000,000 TPY)

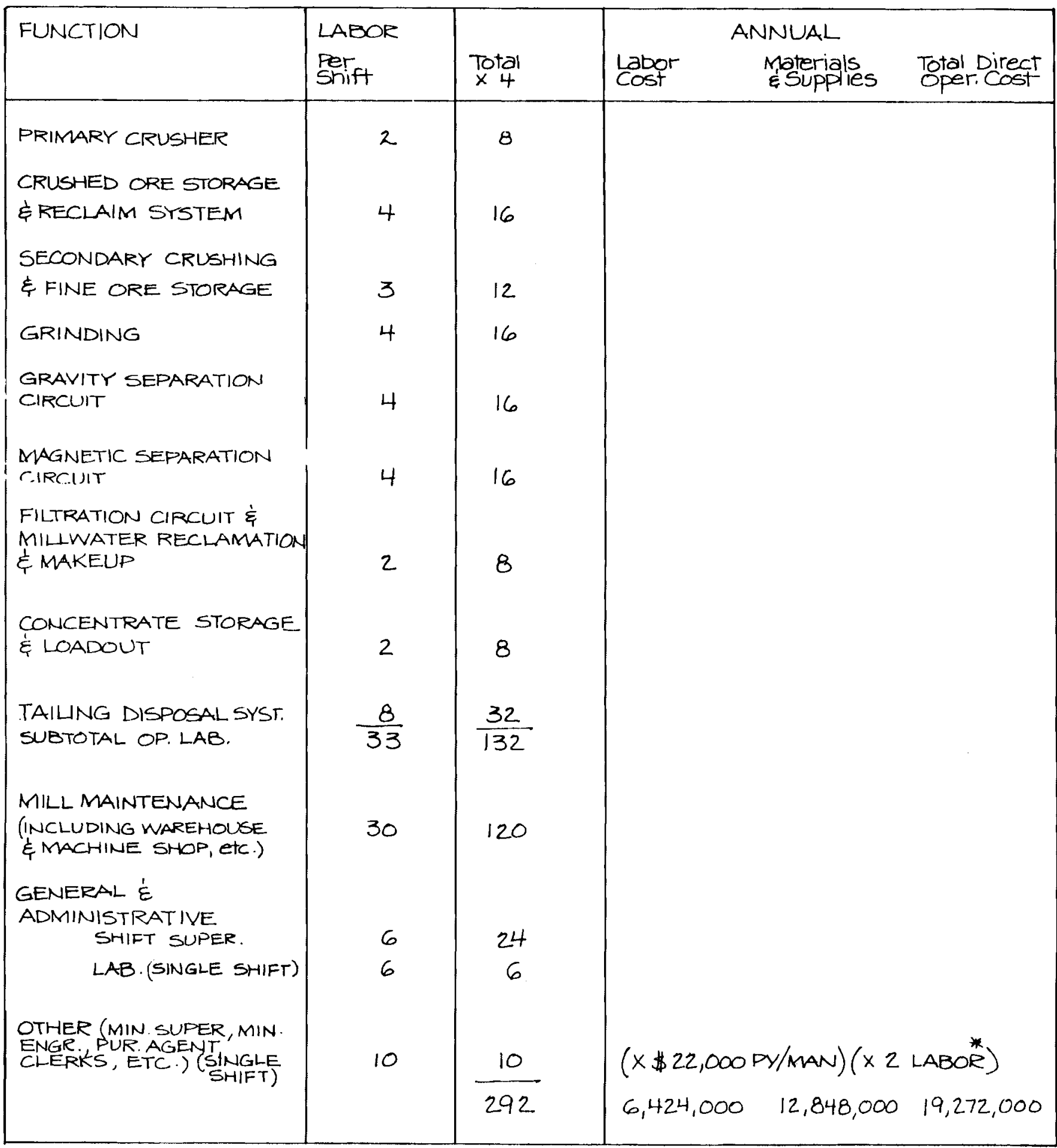

TOTAL DIRECT MILLING

* LABor = 1/3 TOTAL DIRECT costs

COSTS $\$ 119,2.72,000$

$\checkmark$ AVG. $73 /$ SHIFT

or $1.93 / 10 \mathrm{~N}$

ANNUAL CAPITAL ADDITIONS : 

OPERATIONAL PHASE: ESTIMATED ANNUAL CAPITAL AND OPERATING COSTS - MINE OPERATIONS (54,167 TPD - 13,000,000 TPY ORE E WASTE)

TABLE A5

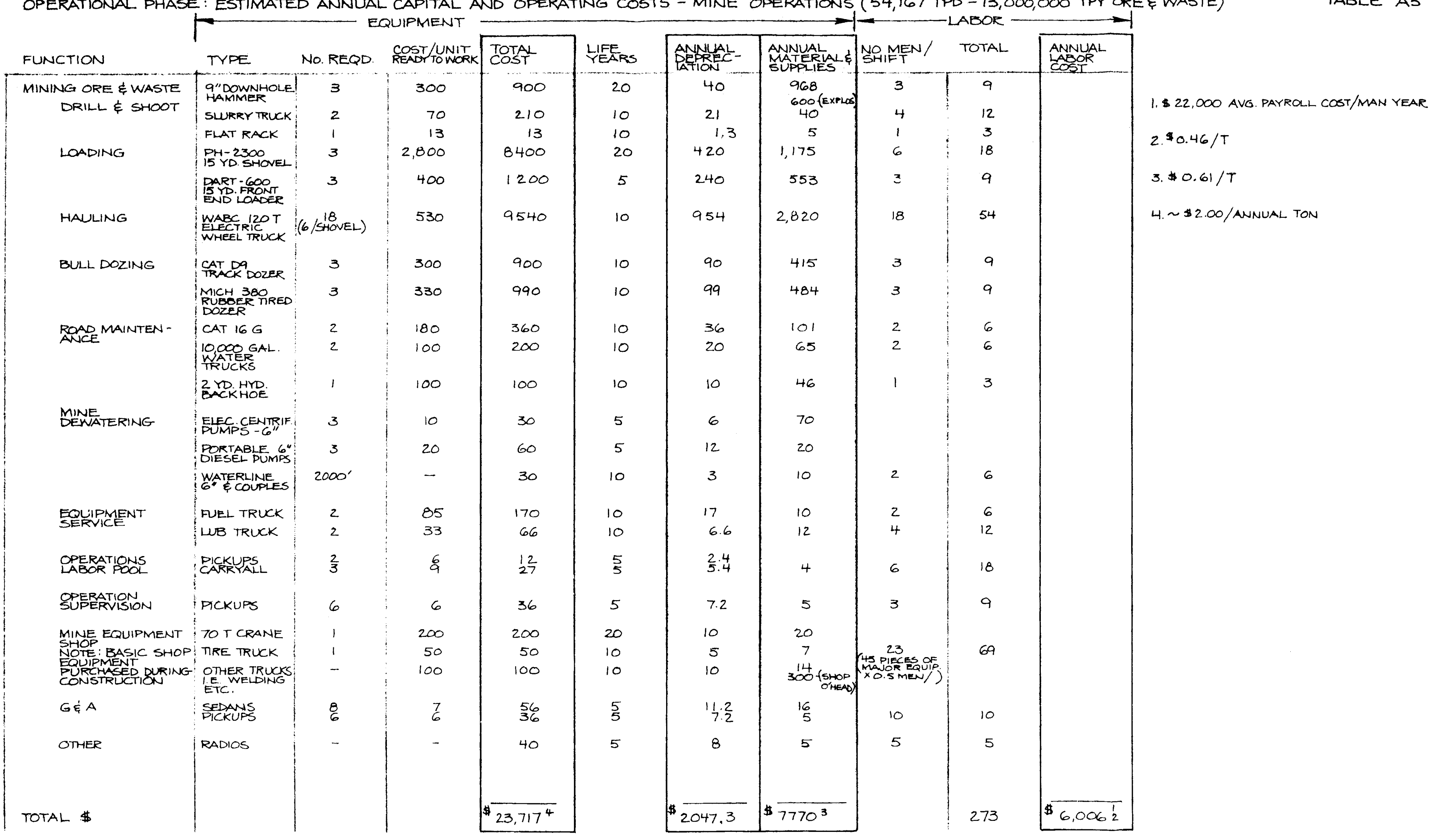



APPENDIX B 


\section{Daily Mine Production Requirements}

The annual daily and shift capacity of the loader will form the basis for the mine production schedule. The mine will work five days per week and three shifts per day (allowing weekends for additional maintanence).

The following number of working days will be assumed: (52 $\mathrm{x} 5$ ) - 10 holidays - 10 days lost to weather and other stoppages;

or 240 days

or $240 \times 3=720$ shifts

The maximum average daily requirement in production year three is therefore: $\underline{13,000,000}=54,167,880$ ore and waste. 240

Ore is $10 \times 54,167=41,667 \mathrm{TPD}$

13

Waste is $\underline{3} \times 54,167=12,500 \mathrm{TPD}$

13

Summary :

Per Day Per Shift

$\begin{array}{llr}\text { Ore and Waste } & 54,167 & 18,056 \\ \text { Waste } & 12,500 & 4,168 \\ \text { Ore } & 41,667 & 13,888\end{array}$

Note: Occasionally all the loaders will be loading ore only (as at time the opposite will be true). Therefore, the primary crushing facilities at the mill should be sized to this case. 
Equipment Selection

Loading Ore and Waste

Consider 15 cubic yard shovels. These shovels will load between 11,000 and 14,000 tons per operating shift. Considering material types and weather a 12,000 ton per shift figure seems reasonable. Mechanical and operating delays will reduce this output to about 60 percent on an average. The average output wil1 then be $12,000 \times .6=7,200$ TP Shift or:

$\underline{7,200}=480 \mathrm{TP}$ shift/yard of rated bucket capacity 12

which agrees quite well with industry experience. To produce $18,056 \mathrm{TP}$ shift, $\underline{18.056}=2.51$

$6 \times 12,000$ or 3 shovels will be required when the mine is at maximum in revenue year 3 .

Examining Table 1 we note:

Reqd.

Ore \& Waste

Shifts

Tons/Shift No. \& Shovel

Year Tons 106 No/Day Total/Year Regd. Calc. Sched.

$\begin{array}{rrrrrrr}-2 & 3 & 1 & 240 & 12,500 & 1.7 & 2 \\ -1 & 3 & 1 & 240 & 12,500 & 1.7 & 2 \\ 1 & 9 & 2 & 480 & 18,750 & 2.6 & 3 \\ 2 & 11 & 3 & 720 & 15,277 & 2.1 & 3 \\ \frac{3}{17} & 13 & 3 & 720 & 18,056 & 2.5 & 3 \\ 18 & 11 & 3 & 720 & 15,277 & 2.1 & 3 \\ 22 & 10 & 3 & 720 & 13,889 & 1.9 & 2 \\ & 1 & 1 & 240 & 4,166 & 0.8 & 1\end{array}$

AIME Mining Handbook Pool

Private reports: Comparison Western U.S. Copper Mines, 1976 


\section{Hauling Ore and Waste}

At this point, assume six 120 ton trucks per shovel including an allowance for spares. This is based on the following analysis:

\section{MIN CUMMIN}

$\begin{array}{lllll}\text { Spot } & & & 0.50 & \\ \text { Load } & 6 \text { swings @ } 0.50 / \text { swing } & 3.00 & 3.50 \\ \text { Haul } & 1.6 \mathrm{M} . @ 10 \mathrm{MPH} & 9.60 & \\ \text { Dump } & & 1.00 & \\ \text { Return } 1.6 \mathrm{M} . @ 14 \mathrm{MPH} & \underline{60} & 21.00 \\ & & & \\ \text { Cycle Time } & & 21.00 & \\ & & & \\ \text { Trucks/Shovel } \frac{21.00-3.50}{3.50}=5+1 \text { spare truck }\end{array}$

Therefore, the basic loading and hauling module will be one 15 cubic yard shovel (P\&H-2300) and six 120 ton trucks (four or five operating 1 and 2 spares). (Wabco 120 electric wheel trucks will be considered.

Drilling Ore and Waste for Blasting

In this study the use of one drill for each shovel has been assumed. 

APPENDIX C 
Summary of Major Assumptions Used in this Study

1. That the Upper Godrich Quartzite:

a. is shaped approximately as indicated by Gair (1975, USGS Prof. Paper 769)

b. has a more or less evenly distributed grade of 14.7 pounds of monazite per ton

c. the monazite is 8.2 percent by weight $\mathrm{ThO}_{2}$

2. That the monazite can be concentrated by milling and that 61 percent by weight can be recovered in the concentrate.

3. That land and mineral rights costs will be approximately as indicated on Table A-2-1.

4. That mill construction costs will be approximately as indicated on Table A-3.

5. That the materials and suppliers component of the direct milling costs will be approximately twice the labor component. 

APPENDIX $F$

ELASTICITY OF BYPRODUCTS FROM THORIUM INDUSTRY 


\section{ELASTICITY OF BYPRODUCTS FROM THORIUM INDUSTRY}

\section{INTRODUCTION}

In the event of large scale thorium production, rare earths, titanium, zirconium, hafnium and columbium will be produced as byproducts. The purpose of this report is to analyze the effect of these minerals on their respective markets. The report will define all byproducts, discuss current sources and sources from the thorium industry. Current and prospective markets will then be analyzed to determine the effect of the thorium industry on byproduct credit.

\section{BACKGROUND}

\section{Rare Earths}

The term "rare earths" came into existence in 1794 when Johann Gadol in assigned it to some poorly understood substances. The term "earth" was then applied to what is now classed as an element. In modern times, rare earths are considered to be the metal oxide form of the element. However, commercially the phrase "rare earth" is used as an adjective (i.e., rare earth oxide, rare earth metal, rare earth chloride, etc.). To avoid confusion, the terms "lanthanide" and "Lanthanoms" have been proposed by V. M. Goldschmidt and J. K. March, respectively, to mean the element form of the rare earths. The term "lanthanides" appears to be gaining favor in scientific circles, but commercially the generic term "rare earths" will probably persist for a long time. (1)

The lanthanides comprise the 15 elements having atomic numbers 57 to 71 , and include, in order, lanthanum (La), cerium (Ce), proseodymium ( $\mathrm{Pr}$ ), neodymium (Nd), promethium ( $\mathrm{Pm})$, samarium (Sm), europium (Eu), gadolinium (Gd), terbium ( $\mathrm{Tb}$ ), dysprosium (Dy), holmium (Ho), erbium (Er), thulium ( $\mathrm{Tm}$ ), Ytterbium (Yb), and lutetium (Lu). Yttrium is also classified as a rare earth element because of its properties despite the fact its atomic number is 39 .

The lanthanide series is divided into two groups. The first seven members (La through Eu) are referred to as the cerium subgroup. Similarly, the remaining eight elements (Gd through $L u$ ) together with yttrium are 
called the yttrium subgroup. The two subgroups are also referred to, respectively, as the "1ight" and "heavy" rare earth elements. (1)

Eight of the rare earths, plus a natural mixture, are commercially important. These include cerium, europium, lanthanum, samarium, yttrium, gasolinium, praseodymium, and neodymium. (2)

The rare earths are found in many minerals and are actually more common than several more familiar elements. Monazite sand is a very important source of rare earths. Placer deposits that contain monazite usually contain ilmenite, rutile, and zircon also.

\section{Titanium}

Titanium is also one of the earth's more abundant elements. The most important ores of titanium are ilmenite $\left(\mathrm{FeTiO}_{3}\right)$ and rutile $\left(\mathrm{TiO}_{2}\right)$. Although ilmenite and rutile commonly occur together, rutile is much less abundant than ilmenite. (3) Ilmenite may vary widely in grade, but its theoretical $\mathrm{TiO}_{2}$ content is $52.8 \%$. Rutile must average $57.4 \% \mathrm{TiO}_{2}$.

Zirconium and Hafnium

Zirconium is a transition metal with properties very similar to hafnium also a transition metal. Chief ores of zirconium are zircon $\left(\mathrm{ZrSiO}_{4}\right)$ and baddeleyite $\left(\mathrm{ZrO}_{2}\right)$. Hafnium is present in almost all zirconium ores in a ratio of about 1:50. (3) Currently marketed zircon contains about $66 \% \mathrm{ZrO}_{2}$ and $\mathrm{HFO}_{2}$.

\section{Columbium--Background}

Columbium is a silver-gray, lustrous metal with an atomic number of 41 and an atomic weight of 92.91. The principal minerals of columbium are columbile and pyrochlore. Pyrochlore concentrates contain $50-55 \% \mathrm{Cb}_{2} \mathrm{O}_{5}$ while columbile concentrate is sold on the basis of $65 \% \mathrm{Cb}_{2} \mathrm{O}_{5}$.

Uranium

Uranium is the first radioactive element to be discovered. It is found in the mineral pitchblend $\left(\mathrm{U}_{3} \mathrm{O}_{8}\right)$, and carnotite $\left(\mathrm{K}_{2}\left(\mathrm{UO}_{2}\right)\left(\mathrm{VO}_{4}\right)_{2} \cdot 8 \mathrm{H}_{2} \mathrm{O}\right)$. Large scale commercial interest in uranium dates from World War II and the development of the atomic bomb. 
Natural uranium contains the isotopes $U_{238}$ ( 99.285 percent), $U_{235}$ (.71 percent), and $U_{234}$ (.005 percent). $U_{235}$ is the only natural occurring fissionable isotope. $U_{238}$ is of major significance because it yields plutonium.

\section{CURRENT SOURCES}

$\underline{\text { Rare Earths }}$

Current mineral sources of rare earths are bastnasite, monazite and xenotime. Monazite and bastnasite contain only negligible amounts of the "heavy" lanthanums, but consist primarily of cerium subgroup elements. Xenootime, however, contains the yttrium subgroup minerals. (1)

Bastnasite rare earth oxide concentrates are produced by open pit mining from a deposit in Mountain Pass, California, by Molycorp, Inc., a subsidiary of Union $0 i l$ of California. Mountain Pass also supplies purified rare earths including cerium, lanthanum, neodymium/praseodymium, gadol inium/samarium, and europium oxide. In 1977, 14,900 tons of contained rare earth oxides were produced by Molycorp with exports consuming $40 \%$. (2)

Monazite sand is also an important commercial source of rare earths. Australia and Malaysia are the main sources of monazite, with U.S. imports totaling 3,300 short tons of rare earth oxides (REO). Monazite is also recovered domestically from placers near Jacksonville, Florida, by Humphrey's Mining Company. About $10 \%$ of the U.S. market for monazite is supplied by domestic resources. Davison Chemical Division, W. R. Grace \& Co. at Chattanooga, Tennessee, is the only monazite processor in the U.S. (2)

Xenotime concentrates are processed primarily for yttrium oxide content. Canada and Malaysia are the principal suppliers. Only a small amount of the total domestic REO tonnage is shipped from these sources. (2)

\section{Titanium}

Major sources of titanium are placer sands which contain varying amounts of ilmenite and rutile. About $70 \%$ of the ilmenite produced in the U.S. comes 
from three mines, two in Florida and one in New York. Other mines in New Jersey and $\mathrm{Florida}$ produce the remaining 30\%. Ilmenite output from the rest of the world comes mostly from Canada, Norway, Australia, and the USSR. (4) In 1977, total domestic mine production from ilmenite was 540,000 tons. Imports of ilmenite amounted to 256,000 tons. Total U.S. consumption of titanium in 1977 was 54,000 tons.

Zirconium

Zircon is the only zirconium ore of commercial significance. It is recovered as a byproduct of titanium mining. Zircon is recovered from mineral sands by Humphrey's Mining Company for Du Pont near Boulougne, Florida; firms in Australia, Japan, and Egypt also process sand for its zircon content. (6) In 1977, total domestic demand for zirconium was 4,300 tons. (7) Columbium

The United States relies on imports for its supply of columbium-bearing ores and concentrates. Brazil, Canada, Thailand, and Nigeria accounted for the majority of columbium imports in 1977. Total imports in 1977 amounted to $2,477,000$ pounds contained columbium. (11)

$\underline{\text { Uranium }}$

About $98 \%$ of domestic reserves at $\$ 10 / 1 \mathrm{~b} \mathrm{U}_{3} \mathrm{O}_{8}$ are in sandstone-type deposits mainly in the Ambrosia Lake district of New Mexico and in Wyoming. Uranium is also recovered as a byproduct of copper and phosphate fertilizer production.

Most of the large economic deposits have a uranium content of . $1 \%$ to . $3 \%$ of $\mathrm{U}_{3} \mathrm{O}_{8}$ averaging . $2 \%$. "Yellowcake", the term applied to the uranium concentrate produced at the mills, is chemically in the form of ammonium diuranite or sodium diuranite. Most concentrates contain a minimum of $.75 \% \mathrm{U}_{3} \mathrm{O}_{8}$. The cost for yellowcake in December 1977 was $\$ 43.20 / 1 b$ of $U_{3} 0_{8}$. 
POTENTIAL SOURCES FROM Th0 2 PRODUCTION

Thorium deposits may also contain significant deposits of rare earths, titanium, zirconium and columbium. During mining and processing, rare earths will be liberated and are potentially recoverable as byproducts. Deposits with this potential include Lemhi Pass, Palmer Michigan, Bald Mountain, Mountain Pass, and all of the placer deposits.

Rare Earths

Thorite veins such as those found in Lemhi Pass, Idaho, Wet Mountain, Colorado, and Powerhorn, Colorado are potential sources of thorium and rare earths. The rare earths are contained largely in the thorite, although small amounts of monazite and zenotime are present. Assuming the rare earth content is equal to the thorium content, approximately 70,000 tons of REO's could be mined with the thorium. An estimate based on spectographic analys is showed yttrium was the dominant element followed first by yttrium subgroup metals and then the light subgroup metals.

Piedmont placer deposits of North and South Carolina constitute another potential source of rare earths. Monazite is by far the most common mineral. There are an estimated 123,000 tons of rare earth oxides available from these placer sources along with about 11,000 tons of $\mathrm{ThO}_{2}$. A typical breakdown of the rare earth composition of monazite is shown in Table F.1.

TABLE F.1. REO Content in Monazite ${ }^{(8)}$

Rare Earths

$(\%)$

Lanthanum

23

Cerium

45

$\left.\begin{array}{l}\text { Proseodymium } \\ \text { Neodymium }\end{array}\right\}$ Dysprosium 25

Samarium

TOTAL Cerium Group

Ytterbium

Other

TOTAL Yttrium Group 
The Mountain Pass, California deposit is currently mined for rare earth elements with a potential for at least 5 million tons. The deposit also contains some thorium estimated at about 28,500 tons. The rare earths portion consists of $56 \%$ cerium, $28.6 \%$ lanthanum, $41 \%$ praseodymium, $10.5 \%$ neodymium, $.6 \%$ samarium, and . $2 \%$ gadol inium. ${ }^{(3)}$ About 2 million tons could be processed as a byproduct of thorium production.

Monazite also exists in conglomerate deposits of Palmer, Michigan, and Bald Mountain, Wyoming. The Palmer deposit contains over 1 million tons of rare earths. Bald Mountain contains an estimated 16,000 tons of rare earth oxides.

The thorium-bearing carbonatite of Iron $\mathrm{Hill}$, Colorado contains rare earths also. Rare earths are estimated at .8\% of the deposit and constitute approximately 810,000 tons.

Titanium

Large-scale production of thorium may, at some period of time, make mining of domestic placer deposits desirable. Beach and stream placers commonly contain both rutile and ilmenite. Mining of placers could result in 400,000 tons of ilmenite (tons $\mathrm{TiO}_{2}$ ). Rutile is much more versatile than ilmenite, but far less common. Mining of placers could result in the production of approximately 23,000 tons of rutile (tons $\mathrm{TiO}_{2}$ ).

Zirconium and Hafnium

Approximately 45,000 tons of zircon are contained in domestic placers. Zircon contains about $66 \% \mathrm{ZrO}_{2}$ including $\mathrm{HfO}_{2} \cdot{ }^{(6)}$ Zirconium and hafnium could be recovered as a byproduct of mining placer sands. 
Columbium

The carbonatite deposit of Powerhorn, Colorado (Iron Hill) is a potential source of byproduct columbium.

The major columbium-bearing mineral is pyrochlore; however, the thoriumbearing minerals are not clearly identified. In all likelihood, pyrochlore also contains some thorium. Unfortunately, other thorium-bearing minerals may be present in the carbonatite. Thus, recovery of both thorium and columbium in a single concentrate may be difficult and, if accomplished, it will result in a lower grade columbium-bearing concentrate than pure pyrochlore. Current chemical processing techniques do not appear to be able to economically recover columbium from such a low grade starting material. However, future research regarding the deposit, benefication techniques, and refining methods might alter the situation. Thus, Iron $\mathrm{Hill}$ is still a potential source of columbium as a byproduct of thorium production. As much as 10,000 tons per year of columbium pentoxides could be liberated as a byproduct of thorium production.

Placer deposits of Bear Valley, Idaho are also a potential source of columbium. The mineral occurs in the form of columbite. In the event of large-scale thorium production, a possible 330 tons per year of columbium pentoxide could be liberated as a byproduct.

Uranium

The primary thorium deposit associated with uranium is the Conway Granite reserve located in New Hampshire. Output is approximately $800,0001 \mathrm{~b} / \mathrm{yr}$ of contained $\mathrm{U}_{3} \mathrm{O}_{8}$. The product will be marketed as yellowcake and sold to uranium production facilities. Approximately $8,750,000$ tons of uranium are contained in this deposit.

Uranium is also contained in monazite from conglomerate and placer deposits. There is approximately 23 parts thorium to 1 part uranium, or 6,000 tons of $\mathrm{U}_{3} \mathrm{O}_{8}$. It is currently not economical to recover placer deposits. Due to the low grade nature of conglomerate deposits, uranium is not economical to recover. 


\section{CURRENT AND PROSPECTIVE MARKETS}

\section{Rare Earths}

Many of the uses of rare earth products are listed in Table F.2. Industrial applications of the rare earths have increased markedly in recent years. The traditional uses of rare earths, including ceramic additives and polishing compounds are, of course, still important, but new industry consumes the bulk of production and consumes much of the rare earth market.

\section{Table F.2. Uses of Rare Earth Elements and Yttrium}

Metallurgy

Glass

Ceramics

Il lumination

Electronic

Nuclear

Chemical

Other
Alloying agents in iron and steel, superalloys, and pyrophoric alloys, lighter flints, pure metals for research.

Polishing, decolorizing, coloring, filters, optical and photochromic glass (camera lenses).

Colorants for enamels and glazes, coatings, refractories and stabilizers.

Carbon arcs, lasers, fluorescent and mercury vapor lamps, phosphors (x-ray intensifiers, display, and color television).

Capacitors, cathodes, electrodes, semiconductors, thermistors, magnets, computer components (garnets and ferrites) and memories.

Control rods, burnable poisons, dilutants, shielding, radioactive heat and power sources, detectors and counters.

Catalysts, pharmaceutical, water treatment, chemical processing and analysis, shift reagents and tags in organic and biological chemistry. Jewelry, photography, lubrication, thermometers, paint and ink dryers, textiles.

Mineral Facts and Problems, 1975 Ed.

Expansion of the rare earths industry depends on the development of new uses. Although demand for rare earths and yttrium grew rapidly during 19651974, the outlook for future growth of the U.S.'s rare earths industry is for a more moderate rate of expansion. Projected demand for rare earth oxides in 
the year 2000 is between 24,000 and 50,000 short tons with 34,000 short tons most probable. (2) The development is hampered in part by the lack of fundamental information on the properties of rare earth compounds and metal. Only a few years ago most of the high purity individual rare earth elements were little more than laboratory curiosity. Other factors affecting the expansions of rare earths usage are consumer hesitancy to accept them, loss of established markets resulting from limited growth of petroleum refining, and substitution of rare earths and yttrium by cheaper or superior materials. (10)

Attainment of the high rare earth forecast depends primarily on continued expansion of established markets, mainly iron and steel industry. Recent potential markets include: 1) new catalysts for automobile exhaust systems and for chemical processing purposes, 2) permanent magnets for computer and electronic systems for trucks and automobiles, and 3 ) hydrogen storage and fueling systems for equipment used in confined areas. (9)

\section{Titanium}

Major markets for titanium are in the manufacture of titanium dioxide pigments which accounts for $85 \%$ of the industrial value. Other uses include titanium sponge, welding rod coatings and carbides, and ceramic and glass formulations.

Titanium dioxide pigment and other titanium compounds have many uses including rubber tires, floor coverings, printing ink, porcelain enamels, wall covering, oil cloth and other coated fabrics, and roof coatings. Several thousand tons of titanium dioxide are used annually in the production of welding rod coatings, glass fibers, ceramic capacitors, and electromechanical transducers. Commercial carbide cutting tools contain $8 \%$ to $85 \%$ titanium carbide. Organotitanium compounds are used as catalysts for various polymerization processes, as water repellants, and in dyeing processes.

Titanium metal is primarily used in aerospace applications including aircraft and guided missile assemblies, spacecraft, and turbine engines for aircraft. The chemical and electrochemical processing industries also use some metal. 
Present technology requires ilmenite or titanium slag for use in making titania pigment via a sulfate process. A chloride process is used to make pigment from rutile. The chloride process is environmentally cleaner, but problems arise since rutile is of limited availability and higher cost. Rutile substitutes, called synthetic rutile, however, can be made from ilmenite. Semi-commercial plants are in India, Japan, and Australia. Research is also being cnducted in the U.S. to determine an economic method of producing domestic rutile substitutes. (4)

The demand for titanium in the U.S. in the year 2000 is projected to range between 1.1 million and 2.0 million tons. The figure of 1.45 million tons is projected as most probable. This is over a 90\% increase in demand from 1977. This increase is due to large demands for metal from turbine aircraft engines. Growth in the use of titanium pigments is due largely to increased population and industrial demand. (5)

\section{Zirconium and Hafnium}

The consumption zirconium has been chiefly in the form of the mineral zircon and as zirconium oxide. Zircon is recovered primarily as a byproduct of titanium mining.

The major use of zircon is for facings on foundry molds. Here, cost controls competition from substitutes. Refractories also employ zircon for specialized application. Small but important uses of zirconium compounds are in chemical products. Another minor use for zircon is in the production of metal and alloys used as structural material for nuclear reactors and chemical processing equipment.

Hafnium is not removed from zirconium for most uses because its presence is not detrimental. However, the two elements must be separated for nuclear purposes. Hafnium is primarily used in the form of the metal. Most metal is used in control rods in nuclear reactors, but minor quantities are used in flashbulbs, optical glass, and in refractory alloys. Small amounts of hafnium oxide are used in research. (6)

U.S. demand for zirconium is currentiy about $4,250^{(7)}$ tons. By the year 2000 , U.S. consumption is estimated at 130,500 tons and 312,000 tons with 223,000 tons estimated as most probable. (6) 
Columbium

Columbium products for trade and industry consist mainly of pyrochlore and columbite concentrates for use by processing industries. Columbium is also used in the form of ferrocolumbium or columbium pentoxide in the manufacture of steel, superalloys, columbium metal, columbium-base alloys, and columbium carbide. The steel industry utilizes columbium to control grain size which, in turn, offers improved strength to weight ratios. Columbiumbased steels, alloys, and metals also offer increased corrosion resistance.

U.S. demand for columbium is forecast at 11 million pounds in 1985 and between 15-29.8 million pounds in the year 2000. Forecasts were based primarily on the demand for the different types of steels and the principal end use of each type. (12)

Uranium

Uranium is primarily utilized as nuclear fuel. Despite adverse factors, this continues to be the major use. Other uses include government sponsored programs -- weapons, propulsion, underground tests, research and development, and space applications. Depleted uranium is used as shielding, castings, weapons parts, and ammunition. Uranium also has a number of chemical uses, including catalyst in plastics manufacture, a colorant in glass and ceramics. It is also used as targets for $x$-ray tubes, electrodes in ultraviolet light sources, and resistors in incandescent lamps.

Nuclear power is expected to assume an increasing share of domestic electric generating capacity. Projections of installed nuclear capacity varies from 380-620 gigawatts electric by the year 2000. Projections for uranium requirements for nuclear uses in the year 2000 vary from 62,000 to 99,000 tons of $\mathrm{U}_{3} \mathrm{O}_{8}$ annually. The low forecast assumes 4,000,000 $\mathrm{MW}$ installed capacity, $2 \%$ tails, enrichment plant tails assay, minimal public acceptance, a maximum energy conservation effort, minimal improvement in reactor construction lead times, and uranium shortages. The high forecast assumes 900,000 MWe installed capacity, adequate uranium supply, public acceptance, and decreased lead time for reactor construction. 


\section{EFFECT OF $\mathrm{ThO}_{2}$ PRODUCTION}

Although our study indicates that byproduct recovery of rare earths is not economically feasible, serious consequences would result if currently subeconomic sources of rare earths were made available. As much as 100,000 tpy of rare earths could be marketed as a result of large-scale thorium production. The market would be flooded unless demand projections were influenced. To accomplish this, lowering the price of the rare earth materials available from thorium production might enable new, cheaper uses for rare earth products to increase demand projections. Most rare earths are marketed as misch metal or as refined rare earth metals and compounds. High prices for processed rare earths are reportedly due to large quantity consumption of chemicals, cost of labor, and substantial plant investment because of relatively low throughput capacity. (10) Thus, it appears that the cost of producing these materials would be only slightly influenced by availability of a cheaper rare earths raw material. Price decreases of rare earth products would not be substantial and demand projections would still be reasonable.

The most likely effect of large-scale production of rare-earths and thorium seems to be the formation of stockpiles resulting in rare earth surpluses. If the price of rare earth raw materials is comparably inexpensive, these stockpiles might be maintained by rare earth processors. However, the stockpiles will probably be maintained by the thorium industry until demand rises sufficiently to utilize supply. With this knowledge, it appears that no byproduct credit is the most realistic assumption for rare earths.

\section{$\underline{\text { Titanium }}$}

The amount of titanium from thorium production could be as high as 23,000 tons of $\mathrm{TiO}_{2}$ equivalent per year. The demand in the year 2000 is estimated at 1.4 million tons of $\mathrm{TiO}_{2}$. Thus, it appears that titanium from the thorium industry could easily be absorbed by the domestic market. 
Problems with marketing ilmenite, however, have been realized because of environmental problems encountered during processing. A surplus of tin slag which can be substituted for ilmenite in pigment manufacture has also reduced the value of ilmenite. But the development of a process for converting ilmenite to rutile will tend to increase the value of ilmenite and offset the current downtrend in the value of ilmenite. Thus, the full price of ilmenite shall be credited to the byproducts in this study.

\section{Zirconium}

As much as 3,000 tons per year of zirconium would be liberated as a byproduct of domestic placer mining. Since the demand for zirconium by the year 2000 is estimated at 223,000 tons, the cost of zirconium should not be influenced by the relatively small amount of byproduct zirconium from the thorium industry. Full byproduct credit for zirconium can be given.

Columbium

If economical methods of obtaining columbium products from carbonatite are developed, problems with marketing the columbium byproducts could develop. Demand in the year 2000 is forecast at a probable 11,150 tons. This is very similar to the possible 10,000 tons per year production from Iron Hill. Competition from other markets might result in price reductions or stockpiling of some of the resource. However, columbium is a useful alloying agent for steel and its use would expand if the price decreased. In this case, a bycredit of $50 \%$ of current market shall be assumed.

\section{Uranium}

Production of Conway Granites would release approximately 400 tpy of $\mathrm{U}_{3} \mathrm{O}_{8}$. The demand in the year 2000 ranges from 30,000 to 99,000 tons of $\mathrm{U}_{3} \mathrm{O}_{8}$. From these estimates it appears that uranium from Conway Granite should easily be marketed with no effect on price. 


\section{REFERENCES}

1. J. G. Parker and C. T. Baroch, The Rare Earth Elements, Yttrium, and Thorium, A Materials Survey. IC-8476, U.S. Bureau of Mines, 1971.

2. J. G. Cannon, "Rare Earths: ' 77 Was Good; ' 78 Looks Even Better." Engineering and Mining Journal, 179(3):184-187, March 1978.

3. W. H. Nebergall, F. C. Schmidt and H. F. Holtzclaw, Jr., General Chemistry, 4th Ed., D. C. Heath and Company, Lexington, MA, 1972.

4. F. W. Wessel, "Titanium." Mineral Facts and Problems, Bulletin 667, U.S. Bureau of Mines, 1975.

5. W. W. Minkler, "Titanium: Shipments Rise Despite Military Cutback." Engineering and Mining Journal, 179(3):137-138, March 1978.

6. S. G. Ampian, "Zirconium and Hafnium." Mineral Facts and Problems. Bulletin 667 , U.S. Burear of Mines, 1975.

7. V. DePoix, "Zirconium: Growth Rate Suffers Setbacks." Engineering and Mining Journal, 179(3):134-135, March 1978.

8. R. J. Callow, The Industrial Chemistry of the Lanthanons, Yttrium, Thorium, and Uranium. Pergamon Press, Long Is Tand, NY, 1967.

9. J. H. Jolly, "Rare Earths." Mineral Facts and Problems, Bulletin 667, U.S. Bureau of Mines, 1975.

10. F. J. Kelly, Technological and Economic Problems of Rare-Earth-Metal and Thorium Resources in Colorado, New Mixico and Wyoming. IC 8124, U.S. Bureau of Mines, update 1976.

11. F. H. Buttner, "Columbium: Riding on Good Pipeline Demand." Engineering and Mining Journal, 179(3):118-120, March 1978.

12. Joseph A. Sutton and Henry E. Stipp, "Columbium." Mineral Facts and Problems, Bulletin 667, U.S. Bureauof Mines, 1975. 


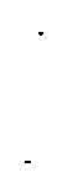


APPENDIX G

FREQUENCY TABLES FOR PRODUCTION COST UNCERTAINTY ANALYSIS OF DOMESTIC THORIUM DEPOSITS 
TABLE G.1. Stockpiles (Chattanooga Sludge)

\begin{tabular}{|c|c|c|c|c|}
\hline $\begin{array}{l}\text { Upper } \\
\text { Limit }\end{array}$ & $\begin{array}{l}\text { Observed } \\
\text { Frequency }\end{array}$ & $\begin{array}{l}\text { Percent } \\
\text { of Total }\end{array}$ & $\begin{array}{l}\text { Cumulative } \\
\text { Percentage }\end{array}$ & $\begin{array}{l}\text { Cumulative } \\
\text { Rema inder }\end{array}$ \\
\hline 4.30 & 1 & 50 & .50 & 99.50 \\
\hline 4.40 & 0 & .00 & .50 & 99.50 \\
\hline 4.50 & 1 & .50 & 1.00 & 99.00 \\
\hline 4.60 & 2 & 1.00 & 2.00 & 98.00 \\
\hline 4.70 & 4 & 2.00 & 4.00 & 96.00 \\
\hline 4.80 & 2 & 1.00 & 5.00 & 95.00 \\
\hline 4.90 & 5 & 2.50 & 7.50 & 92.50 \\
\hline 5.00 & 3 & 1.50 & 9.00 & 91.00 \\
\hline 5.10 & 6 & 3.00 & 12.00 & 88.00 \\
\hline 5.20 & 6 & 3.00 & 15.00 & 85.00 \\
\hline 5.30 & 8 & 4.00 & 19.00 & 81.00 \\
\hline 5.40 & 11 & 5.50 & 24.50 & 75.50 \\
\hline 5.50 & 12 & 6.00 & 30.50 & 69.50 \\
\hline 5.60 & 9 & 4.50 & 35.00 & 65.00 \\
\hline 5.70 & 14 & 7.00 & 42.00 & 58.00 \\
\hline 5.80 & 10 & 5.00 & 47.00 & 53.00 \\
\hline 5.90 & 14 & 7.00 & 54.00 & 46.00 \\
\hline 6.00 & 11 & 5.50 & 59.50 & 40.50 \\
\hline 6.10 & 6 & 3.00 & 62.50 & 37.50 \\
\hline 6.20 & 4 & 2.00 & 64.50 & 35.50 \\
\hline 6.30 & 6 & 3.00 & 67.50 & 32.50 \\
\hline 6.40 & 12 & 6.00 & 73.50 & 26.50 \\
\hline 6.50 & 8 & 4.00 & 77.50 & 22.50 \\
\hline 6.60 & 5 & 2.50 & 80.00 & 20.00 \\
\hline 6.70 & 5 & 2.50 & 82.50 & 17.50 \\
\hline 6.80 & 7 & 3.50 & 86.00 & 14.00 \\
\hline 6.90 & 7 & 3.50 & 89.50 & 10.50 \\
\hline 7.00 & 4 & 2.00 & 91.50 & 8.50 \\
\hline 7.10 & 4 & 2.00 & 93.50 & 6.50 \\
\hline 7.20 & 1 & .50 & 94.00 & 6.00 \\
\hline 7.30 & 2 & 1.00 & 95.00 & 5.00 \\
\hline 7.40 & 3 & 1.50 & 96.50 & 3.50 \\
\hline 7.50 & 1 & .50 & 97.00 & 3.00 \\
\hline 7.60 & 0 & .00 & 97.00 & 3.00 \\
\hline 7.70 & 2 & 1.00 & 98.00 & 2.00 \\
\hline 7.80 & 0 & .00 & 98.00 & 2.00 \\
\hline 7.90 & 1 & .50 & 98.50 & 1.50 \\
\hline 8.00 & 1 & .50 & 99.00 & 1.00 \\
\hline 8.10 & 0 & .00 & 99.00 & 1.00 \\
\hline 8.20 & 1 & .50 & 99.50 & .50 \\
\hline 8.30 & 0 & .00 & 99.50 & .50 \\
\hline 8.40 & 0 & .00 & 99.50 & .50 \\
\hline 8.50 & 1 & .50 & 100.00 & .00 \\
\hline
\end{tabular}


TABLE G.2. Stockpiles (Curtis Bay--Miamisburg Sludge)

\begin{tabular}{|c|c|c|c|c|}
\hline $\begin{array}{l}\text { Upper } \\
\text { Limit }\end{array}$ & $\begin{array}{l}\text { Observed } \\
\text { Frequency }\end{array}$ & $\begin{array}{l}\text { Percent } \\
\text { of Total }\end{array}$ & $\begin{array}{l}\text { Cumulative } \\
\text { Percentage }\end{array}$ & $\begin{array}{l}\text { Cumulative } \\
\text { Remainder }\end{array}$ \\
\hline 2.86 & 2 & 1.00 & 1.00 & 99.00 \\
\hline 2.94 & 1 & .50 & 1.50 & 98.50 \\
\hline 3.02 & 2 & 1.00 & 2.50 & 97.50 \\
\hline 3.10 & 2 & 1.00 & 3.50 & 96.50 \\
\hline 3.18 & 1 & .50 & 4.00 & 96.00 \\
\hline 3.26 & 5 & 2.50 & 6.50 & 93.50 \\
\hline 3.34 & 10 & 5.00 & 11.50 & 88.50 \\
\hline 3.42 & 7 & 3.50 & 15.00 & 85.00 \\
\hline 3.50 & 12 & 6.00 & 21.00 & 79.00 \\
\hline 3.58 & 9 & 4.50 & 25.50 & 74.50 \\
\hline 3.66 & 12 & 6.00 & 31.50 & 68.50 \\
\hline 3.74 & 11 & 5.50 & 37.00 & 63.00 \\
\hline 3.82 & 14 & 7.00 & 44.00 & 56.00 \\
\hline 3.90 & 10 & 5.00 & 49.00 & 51.00 \\
\hline 3.98 & 13 & 6.50 & 55.50 & 44.50 \\
\hline 4.06 & 13 & 6.50 & 62.00 & 38.00 \\
\hline 4.14 & 9 & 4.50 & 66.50 & 33.50 \\
\hline 4.22 & 7 & 3.50 & 70.00 & 30.00 \\
\hline 4.30 & 14 & 7.00 & 77.00 & 23.00 \\
\hline 4.38 & 8 & 4.00 & 81.00 & 19.00 \\
\hline 4.46 & 4 & 2.00 & 83.00 & 17.00 \\
\hline 4.54 & 9 & 4.50 & 87.50 & 12.50 \\
\hline 4.62 & 7 & 3.50 & 91.00 & 9.00 \\
\hline 4.70 & 3 & 1.50 & 92.50 & 7.50 \\
\hline 4.78 & 2 & 1.00 & 93.50 & 6.50 \\
\hline 4.86 & 1 & .50 & 94.00 & 6.00 \\
\hline 4.94 & 1 & .50 & 94.50 & 5.50 \\
\hline 5.02 & 0 & .00 & 94.50 & 5.50 \\
\hline 5.10 & 1 & .50 & 95.00 & 5.00 \\
\hline 5.18 & 5 & 2.50 & 97.50 & 2.50 \\
\hline 5.26 & 1 & .50 & 98.00 & 2.00 \\
\hline 5.34 & 0 & .00 & 98.00 & 2.00 \\
\hline 5.42 & 1 & .50 & 98.50 & 1.50 \\
\hline 5.50 & 1 & .50 & 99.00 & 1.00 \\
\hline 5.58 & 2 & 1.00 & 100.00 & .00 \\
\hline
\end{tabular}


TABLE G.3. Stockpiles (Fernald Sludge)

\begin{tabular}{|c|c|c|c|c|}
\hline $\begin{array}{l}\text { Upper } \\
\text { Limit } \\
\end{array}$ & $\begin{array}{l}\text { Observed } \\
\text { Frequency }\end{array}$ & $\begin{array}{l}\text { Percent } \\
\text { of Total } \\
\end{array}$ & $\begin{array}{l}\text { Cumulative } \\
\text { Percentage } \\
\end{array}$ & $\begin{array}{l}\text { Cumulative } \\
\text { Remainder } \\
\end{array}$ \\
\hline 2.02 & 2 & 1.00 & 1.00 & 99.00 \\
\hline 2.08 & 1 & .50 & 1.50 & 98.50 \\
\hline 2.14 & 2 & 1.00 & 2.50 & 97.50 \\
\hline 2.20 & 2 & 1.00 & 3.50 & 96.50 \\
\hline 2.26 & 7 & 3.50 & 7.00 & 93.00 \\
\hline 2.32 & 9 & 4.50 & 11.50 & 88.50 \\
\hline 2.38 & 8 & 4.00 & 15.50 & 84.50 \\
\hline 2.44 & 13 & 6.50 & 22.00 & 78.00 \\
\hline 2.50 & 8 & 4.00 & 26.00 & 74.00 \\
\hline 2.56 & 13 & 6.50 & 32.50 & 67.50 \\
\hline 2.62 & 6 & 3.00 & 35.50 & 64.50 \\
\hline 2.68 & 12 & 6.00 & 41.50 & 58.50 \\
\hline 2.74 & 13 & 6.50 & 48.00 & 52.00 \\
\hline 2.80 & 14 & 7.00 & 55.00 & 45.00 \\
\hline 2.86 & 10 & 5.00 & 60.00 & 40.00 \\
\hline 2.92 & 12 & 6.00 & 66.00 & 34.00 \\
\hline 2.98 & 9 & 4.50 & 70.50 & 29.50 \\
\hline 3.04 & 5 & 2.50 & 73.00 & 27.00 \\
\hline 3.10 & 7 & 3.50 & 76.50 & 23.50 \\
\hline 3.16 & 12 & 6.00 & 82.50 & 17.50 \\
\hline 3.22 & 4 & 2.00 & 84.50 & 15.50 \\
\hline 3.28 & 7 & 3.50 & 88.00 & 12.00 \\
\hline 3.34 & 3 & 1.50 & 89.50 & 10.50 \\
\hline 3.40 & 4 & 2.00 & 91.50 & 8.50 \\
\hline 3.46 & 3 & 1.50 & 93.00 & 7.00 \\
\hline 3.52 & 4 & 2.00 & 95.00 & 5.00 \\
\hline 3.58 & 3 & 1.50 & 96.50 & 3.50 \\
\hline 3.64 & 2 & 1.00 & 97.50 & 2.50 \\
\hline 3.70 & 2 & 1.00 & 98.50 & 1.50 \\
\hline 3.76 & 0 & .00 & 98.50 & 1.50 \\
\hline 3.82 & 0 & .00 & 98.50 & 1.50 \\
\hline 3.88 & 0 & .00 & 98.50 & 1.50 \\
\hline 3.94 & 0 & .00 & 98.50 & 1.50 \\
\hline 4.00 & 1 & .50 & 99.00 & 1.00 \\
\hline 4.06 & 0 & .00 & 99.00 & 1.00 \\
\hline 4.12 & 0 & .00 & 99.00 & 1.00 \\
\hline 4.18 & 1 & .50 & 99.50 & .50 \\
\hline 4.24 & 1 & .50 & 100.00 & .00 \\
\hline
\end{tabular}


TABLE G.4. Hall Mountain

\begin{tabular}{|c|c|c|c|c|}
\hline $\begin{array}{l}\text { Upper } \\
\text { Limit }\end{array}$ & $\begin{array}{l}\text { Observed } \\
\text { Frequency } \\
\end{array}$ & $\begin{array}{l}\text { Percent } \\
\text { of Total } \\
\end{array}$ & $\begin{array}{l}\text { Cumulative } \\
\text { Percentage }\end{array}$ & $\begin{array}{l}\text { Cumulative } \\
\text { Remainder } \\
\end{array}$ \\
\hline 5.60 & 1 & .50 & .50 & 99.50 \\
\hline 5.70 & 1 & .50 & 1.00 & 99.00 \\
\hline 5.80 & 3 & 1.50 & 2.50 & 97.50 \\
\hline 5.90 & 2 & 1.00 & 3.50 & 96.50 \\
\hline 6.00 & 7 & 3.50 & 7.00 & 93.00 \\
\hline 6.10 & 6 & 3.00 & 10.00 & 90.00 \\
\hline 6.20 & 8 & 4.00 & 14.00 & 86.00 \\
\hline 6.30 & 14 & 7.00 & 21.00 & 79.00 \\
\hline 6.40 & 5 & 2.50 & 23.50 & 78.50 \\
\hline 6.50 & 12 & 6.00 & 29.50 & 70.50 \\
\hline 6.60 & 13 & 6.50 & 36.00 & 64.00 \\
\hline 6.70 & 13 & 6.50 & 42.50 & 57.50 \\
\hline 6.80 & 10 & 5.00 & 47.50 & 52.50 \\
\hline 6.90 & 12 & 6.00 & 53.50 & 46.50 \\
\hline 7.00 & 4 & 2.00 & 55.50 & 44.50 \\
\hline 7.10 & 12 & 6.00 & 61.50 & 38.50 \\
\hline 7.20 & 9 & 4.50 & 65.00 & 34.00 \\
\hline 7.30 & 8 & 4.00 & 70.00 & 31.00 \\
\hline 7.40 & 4 & 2.00 & 72.00 & 28.00 \\
\hline 7.50 & 6 & 3.00 & 75.00 & 25.00 \\
\hline 7.60 & 4 & 2.00 & 77.00 & 23.00 \\
\hline 7.70 & 3 & 1.50 & 78.50 & 21.50 \\
\hline 7.80 & 7 & 3.50 & 82.00 & 18.00 \\
\hline 7.90 & 4 & 2.00 & 84.00 & 16.00 \\
\hline 8.00 & 5 & 2.50 & 86.50 & 13.50 \\
\hline 8.10 & 2 & 1.00 & 87.50 & 12.50 \\
\hline 8.20 & 3 & 1.50 & 89.00 & 11.00 \\
\hline 8.30 & 3 & 1.50 & 90.50 & 8.50 \\
\hline 8.40 & 5 & 2.50 & 93.00 & 7.00 \\
\hline 8.50 & 4 & 2.00 & 95.00 & 5.00 \\
\hline 8.60 & 5 & 2.00 & 97.00 & 3.00 \\
\hline 8.70 & 2 & 1.00 & 98.00 & 2.00 \\
\hline 8.80 & 0 & .00 & 98.00 & 2.00 \\
\hline 8.90 & 0 & .00 & 98.00 & 2.00 \\
\hline 9.00 & 0 & .00 & 98.00 & 2.00 \\
\hline 9.10 & 2 & 1.00 & 98.00 & 1.00 \\
\hline 9.20 & 0 & .00 & 98.00 & 1.00 \\
\hline 9.30 & 2 & 1.00 & 100.00 & .00 \\
\hline
\end{tabular}


TABLE G.5. Lemhi Pass (Stage 1)

\begin{tabular}{|c|c|c|c|c|}
\hline $\begin{array}{l}\text { Upper } \\
\text { Limit }\end{array}$ & $\begin{array}{l}\text { Observed } \\
\text { Frequency }\end{array}$ & $\begin{array}{l}\text { Percent } \\
\text { of Total }\end{array}$ & $\begin{array}{l}\text { Cumulative } \\
\text { Percentage }\end{array}$ & $\begin{array}{l}\text { Cumulative } \\
\text { Remainder }\end{array}$ \\
\hline 11.10 & 1 & .50 & .50 & 99.50 \\
\hline 11.40 & 0 & .00 & .50 & 99.50 \\
\hline 11.70 & 0 & .00 & .50 & 99.50 \\
\hline 12.00 & 3 & 1.50 & 2.00 & 98.00 \\
\hline 12.30 & 2 & 1.00 & 3.00 & 97.00 \\
\hline 12.60 & 1 & .50 & 3.50 & 96.50 \\
\hline 12.90 & 6 & 3.00 & 6.50 & 93.50 \\
\hline 13.20 & 7 & 3.50 & 10.00 & 90.00 \\
\hline 13.50 & 6 & 3.00 & 13.00 & 87.00 \\
\hline 13.80 & 9 & 4.50 & 17.50 & 82.50 \\
\hline 14.10 & 12 & 6.00 & 23.50 & 76.50 \\
\hline 14.40 & 11 & 5.50 & 29.00 & 71.00 \\
\hline 14.70 & 6 & 3.00 & 32.00 & 68.00 \\
\hline 15.00 & 11 & 5.50 & 37.50 & 62.50 \\
\hline 15.30 & 10 & 5.00 & 42.50 & 57.50 \\
\hline 15.60 & 15 & 7.50 & 50.00 & 50.00 \\
\hline 15.90 & 11 & 5.50 & 55.50 & 44.50 \\
\hline 16.20 & 12 & 6.00 & 61.50 & 38.50 \\
\hline 16.50 & 11 & 5.50 & 67.00 & 33.00 \\
\hline 16.80 & 11 & 5.50 & 72.50 & 27.50 \\
\hline 17.10 & 4 & 2.00 & 74.50 & 25.50 \\
\hline 17.40 & 7 & 3.50 & 78.00 & 22.00 \\
\hline 17.70 & 12 & 6.00 & 84.00 & 16.00 \\
\hline 18.00 & 8 & 4.00 & 88.00 & 12.00 \\
\hline 18.30 & 4 & 2.00 & 90.00 & 10.00 \\
\hline 18.60 & 5 & 2.50 & 92.50 & 7.50 \\
\hline 18.90 & 4 & 2.00 & 94.50 & 5.50 \\
\hline 19.20 & 1 & .50 & 95.00 & 5.00 \\
\hline 19.50 & 2 & 1.00 & 96.00 & 4.00 \\
\hline 19.80 & 1 & .50 & 96.50 & 3.50 \\
\hline 20.10 & 2 & 1.00 & 97.50 & 2.50 \\
\hline 20.40 & 2 & 1.00 & 98.50 & 1.50 \\
\hline 20.70 & 0 & .00 & 98.50 & 1.50 \\
\hline 21.00 & 2 & 1.00 & 99.50 & .50 \\
\hline 21.30 & 0 & .00 & 99.50 & .50 \\
\hline 21.60 & 0 & .00 & 99.50 & .50 \\
\hline 21.90 & 0 & .00 & 99.50 & .50 \\
\hline 22.20 & 0 & .00 & 99.50 & .50 \\
\hline 22.50 & 0 & .00 & 99.50 & .50 \\
\hline 22.80 & 0 & .00 & 99.50 & .50 \\
\hline 23.10 & 1 & .50 & 100.00 & .00 \\
\hline
\end{tabular}


TABLE G.6. Lemhi Pass (Stage 2)

\begin{tabular}{|c|c|c|c|c|}
\hline $\begin{array}{l}\text { Upper } \\
\text { Limit }\end{array}$ & $\begin{array}{l}\text { Observed } \\
\text { Frequency }\end{array}$ & $\begin{array}{l}\text { Percent } \\
\text { of Total }\end{array}$ & $\begin{array}{l}\text { Cumulative } \\
\text { Percentage }\end{array}$ & $\begin{array}{l}\text { Cumulative } \\
\text { Remainder }\end{array}$ \\
\hline 9.10 & 3 & 1.50 & 1.50 & 98.50 \\
\hline 9.30 & 2 & 1.00 & 2.50 & 97.50 \\
\hline 9.50 & 3 & 1.50 & 4.00 & 96.00 \\
\hline 9.70 & 3 & 1.50 & 5.50 & 94.50 \\
\hline 9.90 & 0 & .00 & 5.50 & 94.50 \\
\hline 10.10 & 6 & 3.00 & 8.50 & 91.50 \\
\hline 10.30 & 1 & .50 & 9.00 & 91.00 \\
\hline 10.50 & 4 & 2.00 & 11.00 & 89.00 \\
\hline 10.70 & 8 & 4.00 & 15.00 & 85.00 \\
\hline 10.90 & 10 & 5.00 & 20.00 & 80.00 \\
\hline 11.10 & 10 & 5.00 & 25.00 & 75.00 \\
\hline 11.30 & 8 & 4.00 & 29.00 & 71.00 \\
\hline 11.50 & 10 & 5.00 & 34.00 & 66.00 \\
\hline 11.70 & 11 & 5.50 & 39.50 & 60.50 \\
\hline 11.90 & 8 & 4.00 & 43.50 & 56.50 \\
\hline 12.10 & 18 & 9.00 & 52.50 & 47.50 \\
\hline 12.30 & 3 & 1.50 & 54.00 & 46.00 \\
\hline 12.50 & 8 & 4.00 & 58.00 & 42.00 \\
\hline 12.70 & 11 & 5.50 & 63.50 & 36.50 \\
\hline 12.90 & 7 & 3.50 & 67.00 & 33.00 \\
\hline 13.10 & 10 & 5.00 & 72.00 & 28.00 \\
\hline 13.30 & 10 & 5.00 & 77.00 & 23.00 \\
\hline 13.50 & 7 & 3.50 & 80.50 & 19.50 \\
\hline 13.70 & 6 & 3.00 & 83.50 & 16.50 \\
\hline 13.90 & 4 & 2.00 & 85.50 & 14.50 \\
\hline 14.10 & 9 & 4.50 & 90.00 & 10.00 \\
\hline 14.30 & 3 & 1.50 & 91.50 & 8.50 \\
\hline 14.50 & 3 & 1.50 & 93.00 & 7.00 \\
\hline 14.70 & 1 & .50 & 93.50 & 6.50 \\
\hline 14.90 & 2 & 1.00 & 94.50 & 5.50 \\
\hline 15.10 & 2 & 1.00 & 95.50 & 4.50 \\
\hline 15.30 & 0 & .00 & 95.50 & 4.50 \\
\hline 15.50 & 5 & 2.50 & 98.00 & 2.00 \\
\hline 15.70 & 1 & .50 & 98.50 & 1.50 \\
\hline 15.90 & 2 & 1.00 & 99.50 & .50 \\
\hline 16.10 & 0 & .00 & 99.50 & .50 \\
\hline 16.30 & 0 & .00 & 99.50 & .50 \\
\hline 16.50 & 0 & .00 & 99.50 & .50 \\
\hline 16.70 & 0 & .00 & 99.50 & .50 \\
\hline 16.90 & 0 & .00 & 99.50 & .50 \\
\hline 17.10 & 0 & .00 & 99.50 & .50 \\
\hline 17.30 & 0 & .00 & 99.50 & .50 \\
\hline 17.50 & 1 & .50 & 100.00 & .00 \\
\hline
\end{tabular}


TABLE G.7. Wet Mountain

\begin{tabular}{|c|c|c|c|c|}
\hline $\begin{array}{l}\text { Upper } \\
\text { Limit }\end{array}$ & $\begin{array}{l}\text { Observed } \\
\text { Frequency }\end{array}$ & $\begin{array}{l}\text { Percent } \\
\text { of Tota1 } \\
\end{array}$ & $\begin{array}{l}\text { Cumulative } \\
\text { Percentage } \\
\end{array}$ & $\begin{array}{l}\text { Cumulative } \\
\text { Rema inder }\end{array}$ \\
\hline $\begin{array}{l}6.10 \\
6.30 \\
6.50 \\
6.70 \\
6.90 \\
7.10 \\
7.30 \\
7.50 \\
7.70 \\
7.90 \\
8.10 \\
8.30 \\
8.50 \\
8.70 \\
8.90 \\
9.10 \\
9.30 \\
9.50 \\
9.70 \\
9.90 \\
10.10 \\
10.30 \\
10.50 \\
10.70 \\
10.90 \\
11.10 \\
11.30 \\
11.50 \\
11.70 \\
11.90 \\
12.10 \\
12.30 \\
12.50 \\
12.70 \\
12.90 \\
13.10 \\
13.30 \\
13.50\end{array}$ & $\begin{array}{r}3 \\
1 \\
2 \\
7 \\
10 \\
9 \\
8 \\
7 \\
11 \\
12 \\
9 \\
14 \\
11 \\
9 \\
11 \\
7 \\
4 \\
7 \\
5 \\
4 \\
2 \\
1 \\
7 \\
4 \\
1 \\
3 \\
6 \\
4 \\
4 \\
5 \\
6 \\
1 \\
2 \\
1 \\
0 \\
1 \\
0 \\
1\end{array}$ & $\begin{array}{l}1.50 \\
.50 \\
1.00 \\
3.50 \\
5.00 \\
4.50 \\
4.00 \\
3.50 \\
5.50 \\
6.00 \\
4.50 \\
7.00 \\
5.50 \\
4.50 \\
5.50 \\
3.50 \\
2.00 \\
3.50 \\
2.50 \\
2.00 \\
1.00 \\
.50 \\
3.50 \\
2.00 \\
.50 \\
1.50 \\
3.00 \\
2.00 \\
2.00 \\
2.50 \\
3.00 \\
.50 \\
1.00 \\
.50 \\
.00 \\
.50 \\
.00 \\
.50\end{array}$ & $\begin{array}{r}1.50 \\
2.00 \\
3.00 \\
6.50 \\
11.50 \\
16.00 \\
20.00 \\
23.50 \\
29.00 \\
35.00 \\
39.50 \\
46.50 \\
52.00 \\
56.50 \\
62.00 \\
65.50 \\
67.50 \\
71.00 \\
73.50 \\
75.50 \\
76.50 \\
77.00 \\
80.50 \\
82.50 \\
83.00 \\
84.50 \\
87.50 \\
89.50 \\
91.50 \\
94.00 \\
97.00 \\
97.50 \\
98.50 \\
99.00 \\
99.00 \\
99.50 \\
99.50 \\
100.00\end{array}$ & $\begin{array}{r}98.50 \\
98.00 \\
97.00 \\
93.50 \\
88.50 \\
84.00 \\
80.00 \\
76.50 \\
71.00 \\
65.00 \\
60.50 \\
53.50 \\
48.00 \\
43.50 \\
38.00 \\
34.50 \\
32.50 \\
29.00 \\
26.50 \\
24.50 \\
23.50 \\
23.00 \\
19.50 \\
17.50 \\
17.00 \\
15.50 \\
12.50 \\
10.50 \\
8.50 \\
6.00 \\
3.00 \\
2.50 \\
1.50 \\
1.00 \\
1.00 \\
.50 \\
.50 \\
.00\end{array}$ \\
\hline
\end{tabular}


TABLE G.8. Palmer, Michigan

\begin{tabular}{|c|c|c|c|c|}
\hline $\begin{array}{l}\text { Upper } \\
\text { Limit }\end{array}$ & $\begin{array}{l}\text { Observed } \\
\text { Frequency }\end{array}$ & $\begin{array}{l}\text { Percent } \\
\text { of Total }\end{array}$ & $\begin{array}{l}\text { Cumulative } \\
\text { Percentage }\end{array}$ & $\begin{array}{l}\text { Cumulative } \\
\text { Remainder }\end{array}$ \\
\hline 9.90 & 6 & 3.00 & 3.00 & 97.00 \\
\hline 10.10 & 2 & 1.00 & 4.00 & 96.00 \\
\hline 10.30 & 1 & .50 & 4.50 & 95.50 \\
\hline 10.50 & $i$ & .50 & 5.00 & 95.00 \\
\hline 10.70 & 3 & 1.50 & 6.50 & 93.50 \\
\hline 10.90 & 10 & 5.00 & 11.50 & 88.50 \\
\hline 11.10 & 1 & .50 & 12.00 & 88.00 \\
\hline 11.30 & 8 & 4.00 & 16.00 & 84.00 \\
\hline 11.50 & 3 & 1.50 & 17.50 & 82.50 \\
\hline 11.70 & 5 & 2.50 & 20.00 & 80.00 \\
\hline 11.90 & 7 & 3.50 & 23.50 & 76.50 \\
\hline 12.10 & 3 & 1.50 & 25.00 & 75.00 \\
\hline 12.30 & 4 & 2.00 & 27.00 & 73.00 \\
\hline 12.50 & 6 & 3.00 & 30.00 & 70.00 \\
\hline 12.70 & 9 & 4.50 & 34.50 & 65.50 \\
\hline 12.90 & 12 & 6.00 & 40.50 & 59.50 \\
\hline 13.10 & 7 & 3.50 & 44.00 & 56.00 \\
\hline 13.30 & 9 & 4.50 & 48.50 & 51.50 \\
\hline 13.50 & 4 & 2.00 & 50.50 & 49.50 \\
\hline 13.70 & 9 & 4.50 & 55.00 & 45.00 \\
\hline 13.90 & 8 & 4.00 & 59.00 & 41.00 \\
\hline 14.10 & 13 & 6.50 & 65.50 & 34.50 \\
\hline 14.30 & 13 & 6.50 & 72.00 & 28.00 \\
\hline 14.50 & 0 & .00 & 72.00 & 28.00 \\
\hline 14.70 & 9 & 4.50 & 76.50 & 23.50 \\
\hline 14.90 & 9 & 4.50 & 81.00 & 19.00 \\
\hline 15.10 & 4 & 2.00 & 83.00 & 17.00 \\
\hline 15.30 & 8 & 4.00 & 87.00 & 13.00 \\
\hline 15.50 & 0 & .00 & 87.00 & 13.00 \\
\hline 15.70 & 4 & 2.00 & 89.00 & 11.00 \\
\hline 15.90 & 1 & .50 & 89.50 & 10.50 \\
\hline 16.10 & 7 & 3.50 & 93.00 & 7.00 \\
\hline 16.30 & 6 & 3.00 & 96.00 & 4.00 \\
\hline 16.50 & 2 & 1.00 & 97.00 & 3.00 \\
\hline 16.70 & 4 & 2.00 & 99.00 & 1.00 \\
\hline 16.90 & 0 & .00 & 99.00 & 1.00 \\
\hline 17.10 & 2 & 1.00 & 100.00 & .00 \\
\hline
\end{tabular}


TABLE G.9. Bald Mountain

\begin{tabular}{|c|c|c|c|c|}
\hline $\begin{array}{l}\text { Upper } \\
\text { Limit } \\
\end{array}$ & $\begin{array}{l}\text { Observed } \\
\text { Frequency }\end{array}$ & $\begin{array}{l}\text { Percent } \\
\text { of Total }\end{array}$ & $\begin{array}{l}\text { Cumulative } \\
\text { Percentage } \\
\end{array}$ & $\begin{array}{l}\text { Cumulative } \\
\text { Rema inder } \\
\end{array}$ \\
\hline 29.00 & 1 & .50 & .50 & 99.50 \\
\hline 30.00 & 0 & .00 & .50 & 99.50 \\
\hline 31.00 & 0 & .00 & .50 & 99.50 \\
\hline 32.00 & 2 & 1.00 & 1.50 & 98.50 \\
\hline 33.00 & 2 & 1.00 & 2.50 & 97.50 \\
\hline 34.00 & 2 & 1.00 & 3.50 & 96.50 \\
\hline 35.00 & 0 & .00 & 3.50 & 96.50 \\
\hline 36.00 & 5 & 2.50 & 6.00 & 94.00 \\
\hline 37.00 & 3 & 1.50 & 7.50 & 92.50 \\
\hline 38.00 & 4 & 2.00 & 9.50 & 90.50 \\
\hline 39.00 & 7 & 3.50 & 13.00 & 87.00 \\
\hline 40.00 & 7 & 3.50 & 16.50 & 83.50 \\
\hline 41.00 & 5 & 2.50 & 19.00 & 81.00 \\
\hline 42.00 & 8 & 4.00 & 23.00 & 77.00 \\
\hline 43.00 & 11 & 5.50 & 28.50 & 71.50 \\
\hline 44.00 & 6 & 3.00 & 31.50 & 68.50 \\
\hline 45.00 & 7 & 3.50 & 35.00 & 65.00 \\
\hline 46.00 & 9 & 4.50 & 39.50 & 60.50 \\
\hline 47.00 & 15 & 7.50 & 47.00 & 53.00 \\
\hline 48.00 & 5 & 2.50 & 49.50 & 50.50 \\
\hline 49.00 & 16 & 8.00 & 57.50 & 42.50 \\
\hline 50.00 & 14 & 7.00 & 64.50 & 35.50 \\
\hline 51.00 & 11 & 5.50 & 70.00 & 30.00 \\
\hline 52.00 & 5 & 2.50 & 72.50 & 27.50 \\
\hline 53.00 & 9 & 4.50 & 77.00 & 23.00 \\
\hline 54.00 & 11 & 5.50 & 82.50 & 17.50 \\
\hline 55.00 & 2 & 1.00 & 83.50 & 16.50 \\
\hline 56.00 & 3 & 1.50 & 85.00 & 15.00 \\
\hline 57.00 & 6 & 3.00 & 88.00 & 12.00 \\
\hline 58.00 & 4 & 2.00 & 90.00 & 10.00 \\
\hline 59.00 & 6 & 3.00 & 93.00 & 7.00 \\
\hline 60.00 & 5 & 2.50 & 95.50 & 4.50 \\
\hline 61.00 & 2 & 1.00 & 98.50 & 3.50 \\
\hline 62.00 & 1 & .50 & 97.00 & 3.00 \\
\hline 63.00 & 3 & 1.50 & 98.50 & 1.50 \\
\hline 64.00 & 0 & .00 & 99.00 & 1.00 \\
\hline 65.00 & 1 & .50 & 99.50 & 1.00 \\
\hline 66.00 & $i$ & .50 & 99.50 & .50 \\
\hline 67.00 & 0 & .00 & 99.50 & .50 \\
\hline 68.00 & 1 & .50 & 100.00 & .00 \\
\hline
\end{tabular}


TABLE G.10. Bear Lodge--North Block

\begin{tabular}{|c|c|c|c|c|}
\hline $\begin{array}{l}\text { Upper } \\
\text { Limit } \\
\end{array}$ & $\begin{array}{l}\text { Observed } \\
\text { Frequency } \\
\end{array}$ & $\begin{array}{l}\text { Percent } \\
\text { of Total } \\
\end{array}$ & $\begin{array}{l}\text { Cumulative } \\
\text { Percentage }\end{array}$ & $\begin{array}{l}\text { Cumulative } \\
\text { Remainder } \\
\end{array}$ \\
\hline 41.00 & 1 & .50 & .50 & 99.50 \\
\hline 42.00 & 0 & .00 & .50 & 99.50 \\
\hline 43.00 & 0 & .00 & .50 & 99.50 \\
\hline 44.00 & 2 & 1.00 & 1.50 & 98.50 \\
\hline 45.00 & 3 & 1.50 & 3.00 & 97.00 \\
\hline 46.00 & 3 & 1.50 & 4.50 & 95.50 \\
\hline 47.00 & 5 & 2.50 & 7.00 & 93.00 \\
\hline 48.00 & 4 & 2.00 & 9.00 & 91.00 \\
\hline 49.00 & 8 & 4.00 & 13.00 & 87.00 \\
\hline 50.00 & 7 & 3.50 & 16.50 & 83.50 \\
\hline 51.00 & 3 & 1.50 & 18.00 & 82.00 \\
\hline 52.00 & 8 & 4.00 & 22.00 & 78.00 \\
\hline 53.00 & 11 & 5.50 & 27.50 & 72.50 \\
\hline 54.00 & 11 & 5.50 & 33.00 & 67.00 \\
\hline 55.00 & 10 & 5.00 & 38.00 & 62.00 \\
\hline 56.00 & 9 & 4.50 & 42.50 & 57.50 \\
\hline 57.00 & 10 & 5.00 & 47.50 & 52.50 \\
\hline 58.00 & 8 & 4.00 & 57.50 & 48.50 \\
\hline 59.00 & 11 & 5.50 & 57.00 & 43.00 \\
\hline 60.00 & 6 & 3.00 & 60.00 & 40.00 \\
\hline 61.00 & 10 & 5.00 & 65.00 & 35.00 \\
\hline 62.00 & 8 & 4.00 & 69.00 & 31.00 \\
\hline 63.00 & 7 & 3.50 & 72.50 & 27.50 \\
\hline 64.00 & 10 & 5.00 & 77.50 & 22.50 \\
\hline 65.00 & 6 & 3.00 & 80.50 & 19.50 \\
\hline 66.00 & 9 & 4.50 & 85.00 & 15.00 \\
\hline 67.00 & 5 & 2.50 & 87.50 & 12.50 \\
\hline 68.00 & 6 & 3.00 & 90.50 & 9.50 \\
\hline 69.00 & 6 & 3.00 & 93.50 & 6.50 \\
\hline 70.00 & 2 & 1.00 & 94.50 & 5.50 \\
\hline 71.00 & 0 & .00 & 94.50 & 5.50 \\
\hline 72.00 & 1 & .50 & 95.00 & 5.00 \\
\hline 73.00 & 4 & 2.00 & 97.00 & 3.00 \\
\hline 74.00 & 4 & 2.00 & 99.00 & 1.00 \\
\hline 75.00 & 1 & .50 & 99.50 & .50 \\
\hline 76.00 & 0 & .00 & 99.50 & .50 \\
\hline 77.00 & 0 & .00 & 99.50 & .50 \\
\hline 78.00 & 1 & .50 & 100.00 & .00 \\
\hline
\end{tabular}


TABLE G.11. Bear Lodge--Central Block

$\begin{array}{lcrrr}\begin{array}{l}\text { Upper } \\ \text { Limit }\end{array} & \begin{array}{l}\text { Observed } \\ \text { Frequency }\end{array} & \begin{array}{c}\text { Percent } \\ \text { of Total }\end{array} & \begin{array}{r}\text { Cumulative } \\ \text { Percentage }\end{array} & \begin{array}{c}\text { Cumulative } \\ \text { Remainder }\end{array} \\ 31.00 & 1 & .50 & .50 & 99.50 \\ 33.00 & 1 & .50 & 1.00 & 99.00 \\ 35.00 & 1 & .50 & 1.50 & 98.50 \\ 37.00 & 1 & 2.50 & 2.00 & 98.00 \\ 39.00 & 5 & 2.00 & 6.50 & 95.50 \\ 41.00 & 4 & 5.00 & 11.50 & 93.50 \\ 43.00 & 10 & 2.00 & 13.50 & 88.50 \\ 45.00 & 4 & 5.00 & 18.50 & 86.50 \\ 47.00 & 10 & 5.00 & 23.50 & 81.50 \\ 49.00 & 10 & 7.50 & 31.00 & 76.50 \\ 51.00 & 15 & 6.50 & 37.50 & 69.00 \\ 53.00 & 13 & 4.50 & 42.00 & 62.50 \\ 55.00 & 9 & 9.50 & 51.50 & 58.00 \\ 57.00 & 19 & 7.00 & 61.50 & 38.50 \\ 59.00 & 20 & 5.50 & 69.00 & 31.00 \\ 61.00 & 15 & 3.50 & 74.50 & 25.50 \\ 63.00 & 11 & 5.50 & 78.00 & 22.00 \\ 65.00 & 7 & 3.00 & 83.50 & 16.50 \\ 67.00 & 11 & 5.50 & 86.50 & 13.50 \\ 69.00 & 6 & 3.00 & 92.00 & 8.00 \\ 71.00 & 11 & 2.50 & 94.00 & 6.00 \\ 73.00 & 4 & .50 & 96.50 & 3.50 \\ 75.00 & 5 & .50 & 97.00 & 3.00 \\ 77.00 & 1 & 1.50 & 97.50 & 2.50 \\ 79.00 & 1 & .50 & 99.00 & 1.00 \\ 81.00 & 3 & .00 & 99.50 & .50 \\ 83.00 & 1 & .00 & 99.50 & .50 \\ 85.00 & 0 & .50 & 99.50 & .50 \\ 87.00 & 0 & & 100.00 & .00 \\ 89.00 & 1 & & & \end{array}$


TABLE G.12. Bear Lodge--South Block

\begin{tabular}{|c|c|c|c|c|}
\hline $\begin{array}{l}\text { Upper } \\
\text { Limit }\end{array}$ & $\begin{array}{l}\text { Observed } \\
\text { Frequency }\end{array}$ & $\begin{array}{l}\text { Percent } \\
\text { of Total }\end{array}$ & $\begin{array}{l}\text { Cumulative } \\
\text { Percentage }\end{array}$ & $\begin{array}{l}\text { Cumulative } \\
\text { Remainder }\end{array}$ \\
\hline 32.00 & 1 & .50 & .50 & 99.50 \\
\hline 34.00 & 1 & .50 & 1.00 & 99.00 \\
\hline 36.00 & $i$ & .50 & 1.50 & 98.50 \\
\hline 38.00 & 1 & .50 & 2.00 & 98.00 \\
\hline 40.00 & 5 & 2.50 & 4.50 & 95.50 \\
\hline 42.00 & 4 & 2.00 & 6.50 & 93.50 \\
\hline 44.00 & 10 & 5.00 & 11.50 & 88.50 \\
\hline 46.00 & 4 & 2.00 & 13.50 & 86.50 \\
\hline 48.00 & 10 & 5.00 & 18.50 & 81.50 \\
\hline 50.00 & 10 & 4.00 & 23.50 & 76.50 \\
\hline 52.00 & 15 & 7.50 & 31.00 & 69.00 \\
\hline 54.00 & 15 & 7.50 & 38.50 & 61.50 \\
\hline 56.00 & 7 & 3.50 & 42.00 & 58.00 \\
\hline 58.00 & 18 & 9.00 & 51.00 & 49.00 \\
\hline 60.00 & 19 & 9.50 & 60.50 & 39.50 \\
\hline 62.00 & 16 & 8.00 & 68.50 & 31.50 \\
\hline 64.00 & 11 & 5.50 & 74.00 & 26.00 \\
\hline 66.00 & 8 & 4.00 & 78.00 & 22.00 \\
\hline 68.00 & 11 & 5.50 & 83.50 & 16.50 \\
\hline 70.00 & 5 & 2.50 & 86.00 & 14.00 \\
\hline 72.00 & 11 & 5.50 & 91.50 & 8.50 \\
\hline 74.00 & 5 & 2.50 & 94.00 & 6.00 \\
\hline 76.00 & 5 & 2.50 & 96.50 & 3.50 \\
\hline 78.00 & 1 & .50 & 97.00 & 3.00 \\
\hline 80.00 & $i$ & .50 & 97.50 & 2.50 \\
\hline 82.00 & 3 & 1.50 & 99.00 & 1.00 \\
\hline 84.00 & 1 & .50 & 99.50 & .50 \\
\hline 86.00 & 0 & .00 & 99.50 & .50 \\
\hline 88.00 & 0 & .00 & 99.50 & .50 \\
\hline 90.00 & 1 & .50 & 100.00 & .00 \\
\hline
\end{tabular}


TABLE G.13. Conway Granite

\begin{tabular}{|c|c|c|c|c|}
\hline $\begin{array}{l}\text { Upper } \\
\text { Limit } \\
\end{array}$ & $\begin{array}{l}\text { Observed } \\
\text { Frequency }\end{array}$ & $\begin{array}{l}\text { Percent } \\
\text { of Total }\end{array}$ & $\begin{array}{l}\text { Cumulative } \\
\text { Percentage } \\
\end{array}$ & $\begin{array}{l}\text { Cumulative } \\
\text { Remainder }\end{array}$ \\
\hline 38.00 & 1 & .50 & .50 & 99.50 \\
\hline 40.00 & $i$ & .50 & 1.00 & 99.00 \\
\hline 42.00 & 1 & .50 & 1.50 & 98.50 \\
\hline 44.00 & 3 & 1.50 & 3.00 & 97.00 \\
\hline 46.00 & 5 & 2.50 & 5.50 & 94.50 \\
\hline 48.00 & 8 & 4.00 & 9.50 & 90.50 \\
\hline 50.00 & 14 & 7.00 & 16.50 & 83.50 \\
\hline 52.00 & 15 & 7.50 & 24.00 & 76.00 \\
\hline 54.00 & 17 & 8.50 & 32.50 & 67.50 \\
\hline 56.00 & 20 & 10.00 & 42.50 & 57.50 \\
\hline 58.00 & 22 & 11.00 & 53.50 & 46.50 \\
\hline 60.00 & 14 & 7.00 & 60.50 & 38.50 \\
\hline 62.00 & 12 & 6.00 & 66.50 & 33.50 \\
\hline 64.00 & 15 & 7.50 & 74.00 & 26.00 \\
\hline 66.00 & 7 & 3.50 & 77.50 & 22.50 \\
\hline 68.00 & 9 & 4.50 & 82.00 & 18.00 \\
\hline 70.00 & 8 & 4.00 & 86.00 & 14.00 \\
\hline 72.00 & 7 & 3.50 & 89.50 & 10.50 \\
\hline 74.00 & 2 & 1.00 & 90.50 & 9.50 \\
\hline 76.00 & 5 & 2.50 & 93.00 & 7.00 \\
\hline 78.00 & 5 & 2.50 & 95.50 & 4.50 \\
\hline 80.00 & 2 & 1.00 & 96.50 & 3.50 \\
\hline 82.00 & 2 & 1.00 & 97.50 & 2.50 \\
\hline 84.00 & 2 & 1.00 & 98.50 & 1.50 \\
\hline 86.00 & 1 & .50 & 99.00 & 1.00 \\
\hline 88.00 & 0 & .00 & 99.00 & 1.00 \\
\hline 90.00 & 1 & .50 & 99.50 & .50 \\
\hline 92.00 & 0 & .00 & 99.50 & .50 \\
\hline 94.00 & 1 & .50 & 100.00 & .00 \\
\hline
\end{tabular}





\section{DISTRIBUTION}

No. of

Copies

OFFSITE

A. A. Churm

DOE Patent Division

9800 S. Cass Ave.

Argonne, IL 60439

W. W. Ballard

Nuclear Power Development

Division

Department of Energy

Washington, DC 20545

27 DOE Technical Information Center

J. H. Cavendish

National Lead Company of Ohio

P.0. Box 39158

Cincinnati, $\mathrm{OH} 45239$

Frank E. Driggers

El DuPont

Savannah River Laboratories

Aiken, SC 29801

D. R. Everhart

Manager

Grand Junction Operation Office

U.S. Dept. of Energy

Grand Junction, CO 81502

Dr. T. W. Offield

U.S. Geological Survey

Federal Center

Box 25046

Mai1 Stop 916

Denver, C0 80225
No. of

Copies

J. A. Patterson

Director of Resource Assessment Operations

12th \& Pennsylvania Ave., N.W.

Mail Stop 6521, RA 224

Washington, DC 20461

Roy Post

University of Arizona

Department of Nuclear

Engineering

Tucson, AZ 85721

W. M. Shaffer III

Acfg. Director

Fuel Cycle Project Office

Savannah River Operations

Office

P.0. Box A

Aiken, SC 29801

M. H. Staatz

U.S. Geological Survey

1711 I1linois Street

Room 327

Golden, C0 80401

\section{ONSITE}

2 DOE Richland Operations Office

H. E. Ransom

P. A. Craig 
No. of

Copies

56 Pacific Northwest Laboratory

C. H. Bloomster (10)

D. E. Deonigi

M. K. Drost

W. I. Ender lin

R. M. Fleischman

C. M. Heeb

0. F. Hill

M. A. Lewallen

R. C. Liikala

M. H. Morgenstern

D. F. Newman

M. Y. Rouse

S. A. Weakley

M. K. White

L. D. Williams

J. K. Young (25)

Technical Information Files (5)

Publishing Coordination (2) 